\begin{abstract}
UNIVERSIDADE DE SÃO PAULO
FACULDADE DE FILOSOFIA, LETRAS E CIÊNCIAS HUMANAS DEPARTAMENTO DE LETRAS CLÁSSICAS E VERNÁCULAS PROGRAMA DE PÓS-GRADUAÇÃO EM ESTUDOS COMPARADOS DE LITERATURAS DE LÍNGUA PORTUGUESA
\end{abstract}

LUCIENE MARIE PAVANELO

Camilo Castelo Branco e Joaquim Manuel de Macedo: convergências na ascensão do romance nas periferias do capitalismo

(versão corrigida)

São Paulo

2013 


\section{Camilo Castelo Branco e Joaquim Manuel de Macedo: convergências na ascensão do romance \\ nas periferias do capitalismo}

(versão corrigida)

Tese apresentada ao Departamento de Letras Clássicas e Vernáculas da Faculdade de Filosofia, Letras e Ciências Humanas da Universidade de São Paulo, para obtenção do título de Doutora em Letras

Área de Concentração: Estudos Comparados de Literaturas de Língua Portuguesa

Orientador: Prof. Dr. Paulo Fernando da Motta de Oliveira

De acordo,

Prof. Dr. Paulo Fernando da Motta de Oliveira

São Paulo

2013 
PAVANELO, Luciene Marie. Camilo Castelo Branco e Joaquim Manuel de Macedo: convergências na ascensão do romance nas periferias do capitalismo. Tese apresentada ao Programa de Pós-Graduação em Estudos Comparados de Literaturas de Língua Portuguesa do Departamento de Letras Clássicas e Vernáculas da Faculdade de Filosofia, Letras e Ciências Humanas da Universidade de São Paulo, para obtenção do título de Doutora em Letras.

Aprovada em: 7 de maio de 2013

Banca Examinadora

Prof. Dr. Paulo Fernando da Motta de Oliveira

Instituição: USP

Julgamento: aprovada

Assinatura:

Prof $^{a}$ Dra. Cilaine Alves Cunha

Instituição: USP

Julgamento: aprovada

Assinatura:

Prof $^{a}$ Dra. Patrícia da Silva Cardoso

Instituição: UFPR

Julgamento: aprovada

Assinatura:

Prof. Dr. Sérgio Paulo Guimarães de Sousa

Instituição: Universidade do Minho

Julgamento: aprovada

Assinatura:

Prof. Dr. Antonio Augusto Nery

Instituição: UFPR

Julgamento: aprovada

Assinatura: 
À minha mãe,

por seu infinito e verdadeiro amor abnegado. 


\section{AGRADECIMENTOS}

Ao meu orientador, Prof. Dr. Paulo Motta Oliveira, por ter me ensinado, nesses nove anos de agradável convivência, que a complexa formação de um pesquisador vai muito além da escrita de uma tese, confiando no meu trabalho e encorajando-me a seguir os seus passos.

Ao Prof. Dr. Sérgio Guimarães de Sousa, pela assistência nos últimos cinco anos e pelos esforços despendidos em sua supervisão da pesquisa realizada em Portugal, que fora imprescindível para tornar este estudo mais completo.

À Prof ${ }^{a}$ Dra. Cilaine Alves Cunha, por ter contribuído de maneira fundamental para a minha formação, durante a graduação, e pelas valiosas sugestões durante o exame de qualificação e a defesa.

À Prof ${ }^{a}$ Dra. Patrícia da Silva Cardoso, pela gentileza com que sempre me tratou e pelos importantes comentários durante a defesa.

Ao Prof. Dr. Antonio Augusto Nery, pelo incentivo amigo e pelos úteis apontamentos durante a defesa.

À Prof ${ }^{a}$ Dra. Márcia Abreu, pelas apreciações durante o exame de qualificação, que muito contribuíram para o aperfeiçoamento deste trabalho.

Ao Prof. Dr. Emerson da Cruz Inácio, por ter sugerido, enquanto cursei sua disciplina, parte essencial da bibliografia que embasou a introdução desta tese.

À Prof ${ }^{a}$ Dra. Raquel Madanêlo Souza, pela amizade preciosa, pelo apoio afetuoso e pela ajuda nos momentos mais necessários.

À Prof ${ }^{\mathrm{a}}$ Dra. Aparecida de Fátima Bueno, pelo auxílio em muitas ocasiões. 
Ao Departamento de Letras Clássicas e Vernáculas da Faculdade de Filosofia, Letras e Ciências Humanas da Universidade de São Paulo, por ter me acolhido durante a graduação, mestrado e doutorado, um ciclo feliz de onze anos, que agora se encerra.

Ao Instituto de Letras e Ciências Humanas da Universidade do Minho e ao Centro de Estudos Camilianos/Casa de Camilo, pela oportunidade de realização de parte desta pesquisa.

À Fundação de Amparo à Pesquisa do Estado de São Paulo, pela concessão da bolsa, que me permitiu dedicação exclusiva a este estudo, e pelo apoio financeiro para a participação em congressos e na execução da pesquisa em Portugal.

À Coordenação de Aperfeiçoamento de Pessoal de Nível Superior, pelos quatorze meses iniciais de bolsa.

À Ana Luísa Patrício Campos de Oliveira, pela amizade sincera, pela força e pelo companheirismo nesses anos de luta, lágrimas e alegrias: não só Portugal, como toda essa longa jornada camiliana não teriam sido os mesmos sem você.

À querida amiga Carla Carvalho Alves, pelos conselhos sempre úteis e por compartilhar comigo as angústias e, sobretudo, as esperanças de nossa carreira.

Ao amigo Adriano Lima Drumond, pelas animadas conversas, ainda que geograficamente distantes.

Ao meu irmão Marcos Obata Pavanelo, por ter sempre cuidado de mim, com sua alegria contagiante.

À minha mãe Mirian Massako Obata, por me apoiar em minhas decisões e por me auxiliar até hoje, de todas as maneiras que pode, a trilhar o meu caminho.

Ao meu namorado Felipe Sampaio Leger, pelos sete anos de paciência, respeito, desvelo e amor imensurável: estar em paz é estar com você, sempre. 


\section{RESUMO}

PAVANELO, Luciene Marie. Camilo Castelo Branco e Joaquim Manuel de Macedo: convergências na ascensão do romance nas periferias do capitalismo. 2013. 260 f. Tese (Doutorado) - Faculdade de Filosofia, Letras e Ciências Humanas, Universidade de São Paulo, São Paulo, 2013.

O objetivo deste trabalho é analisar a ficção de Camilo Castelo Branco e Joaquim Manuel de Macedo, escritores muito populares em Portugal e no Brasil, respectivamente, entre as décadas de 1840 e 1880, período em que publicaram suas expressivas produções, que englobam romances, contos, poemas e peças de teatro, que foram, de certa forma, obliteradas pela historiografia literária ao longo do século XX. A fim de abranger uma parte significativa de suas produções ficcionais, foram selecionadas obras que, num primeiro momento, poderiam representar os principais subgêneros do romance oitocentista: os romances sentimentais Amor de Perdição e A Moreninha; as narrativas de viagem Vinte Horas de Liteira e A Carteira de Meu Tio; as narrativas fantásticas O Esqueleto e A Luneta Mágica; os romances históricos O Demônio do Ouro e As Mulheres de Mantilha; e os romances (pré-) naturalistas $O$ Senhor Ministro e As Vítimas-Algozes. A partir da leitura destas obras, é possível depreender aspectos convergentes entre os autores, como a subversão de algumas convenções romanescas, a quebra de expectativas de leitura e o desvio das temáticas recorrentes e dos procedimentos narrativos mais usuais no século XIX. Sendo assim, o estudo parte da hipótese de que, por terem sido protagonistas da ascensão do romance em Portugal e no Brasil, periferias do capitalismo - na expressão utilizada por Roberto Schwarz -, países que, além disso, partilhavam a mesma língua e um fundo cultural comum, esses escritores compartilharam contextos socioculturais, de certa forma, similares. Se por um lado, a fim de atender ao mercado consumidor, precisavam manter os laços com a literatura em voga, por outro procuravam distanciar-se dela, num movimento de adesão e repulsa aos modelos romanescos.

Palavras-chave: Camilo Castelo Branco. Joaquim Manuel de Macedo. Ascensão do Romance. Subgêneros do Romance. Romance Oitocentista. 


\begin{abstract}
PAVANELO, Luciene Marie. Camilo Castelo Branco and Joaquim Manuel de Macedo: convergences in the rise of the novel in the peripheries of capitalism. 2013. $260 \mathrm{f}$. Thesis (PhD) - Faculdade de Filosofia, Letras e Ciências Humanas, Universidade de São Paulo, São Paulo, 2013.
\end{abstract}

The objective of this work is to analyze the fiction of Camilo Castelo Branco and Joaquim Manuel de Macedo, very popular writers in Portugal and Brazil, respectively, among the 1840 's and 1880's, a period in which they published their expressive productions, which include novels, short stories, poems and plays, that were somehow obliterated by literary historiography throughout the $20^{\text {th }}$ century. In order to cover a significant part of their fictional productions, works that, at first, could represent the major subgenres of $19^{\text {th }}$ century novel were selected: the sentimental novels Amor de Perdição and A Moreninha; the travel narratives Vinte Horas de Liteira and A Carteira de Meu Tio; the fantastic narratives $O$ Esqueleto and A Luneta Mágica; the historical novels O Demônio do Ouro and As Mulheres de Mantilha; and the (pre-)naturalist novels O Senhor Ministro and As Vitimas-Algozes. From the reading of these works, it is possible to deduce converging aspects between these authors, as the subversion of novelistic conventions, the break of reading expectations and the deviation from the recurring thematic and the narrative procedures most commonly used in the $19^{\text {th }}$ century. Thus, the study starts from the hypothesis that, because they were protagonists of the rise of the novel in Portugal and Brazil, peripheries of capitalism - in the expression used by Roberto Schwarz -, countries that also shared the same language and a common cultural background, these writers shared, in some ways, similar socio-cultural contexts. On one hand, in order to serve the consumer market, they needed to maintain ties with the literature in vogue, on the other they sought to distance themselves from it, in a movement of attraction and repulsion by the novelistic models.

Keywords: Camilo Castelo Branco. Joaquim Manuel de Macedo. Rise of the Novel. Subgenres of the Novel. Nineteenth-Century Novel. 


\section{SUMÁRIO}

1. Introdução

2. A ascensão do romance nas periferias do capitalismo

3. O romance sentimental e o riso autoirônico: paralelos entre best-sellers 35

3.1 Amor de Perdição, uma história de homens, feitos bárbaros, em nome de sua honra ..... 41

3.2 A Moreninha e o bichinho que obriga a fazer quanta parvoíce há neste mundo

4. Além da paisagem nacional: a (ausência da) descrição em narrativas de viagem 67

4.1 Vinte Horas de Liteira na superfície escabrosa do globo 72

4.2 A Carteira de Meu Tio e isto de pátria, honra, lealdade, tudo é ficção, tudo é poesia 85

5. Lunetas mágicas e esqueletos: releituras da narrativa fantástica 98

5.1 O Esqueleto, uma história que faz arrepiar os cabelos? 104

5.2 A Luneta Mágica que torna cético ou ludíbrio do mundo e dos homens

6. Um outro romance histórico: heroísmo e nacionalismo em questão

6.1 O Demônio do Ouro e um brasileiro de Minas chamado Joaquim José da Silva Xavier 140

6.2 As Mulheres de Mantilha em que amor é este, entre pessoas que não se podem casar .. 154

6.2.1 Casamento como única saída? Não em As Três Irmãs 168

7. Do científico para o social: o discurso naturalista refutado 174

7.1 O Senhor Ministro e o elemento mesológico de objetivo imanente ou transcendente ... 180

7.2 As Vítimas-Algozes e a escravidão que caleja, petrifica e mata o coração do homem

8. Conclusão

9. Bibliografia 


\section{Introdução}

Quando pensamos em Camilo Castelo Branco (1825-1890) e Joaquim Manuel de Macedo (1820-1882), nossa memória escolar nos remete a Amor de Perdição (1862) e A Moreninha (1844), dois dos maiores best-sellers da ficção oitocentista portuguesa e brasileira, respectivamente. Ambos tiveram dez edições até o final do século XIX, o que mostra a grande recepção que tiveram por parte do público leitor da época: a décima edição do romance ${ }^{1}$ camiliano foi publicada no Porto pela Empresa Literária e Tipográfica², em 1899, e a décima edição da obra de Macedo foi lançada no Rio de Janeiro pela Garnier, no mesmo ano. Se observarmos as diversas edições recentes à venda nas livrarias brasileiras, percebemos que ainda hoje esses dois romances são bastante consumidos, principalmente como livros paradidáticos para o Ensino Fundamental e $\mathrm{Médio}^{3}$ - se não podemos afirmar que são de fato

\footnotetext{
${ }^{1}$ Ao observarmos as fortunas críticas sobre Camilo e sobre Macedo, verificamos que suas produções ficcionais têm recebido os mais variados rótulos, entre eles termos controversos como "novela", "sátira de costumes" e "crônica romanceada", que, além de vagos, carregam certa carga pejorativa - principalmente o primeiro deles -, o que acaba desmerecendo o seu valor literário. Como afirma Paulo Motta Oliveira, "considerar Camilo como um autor de novelas, e não de romances, parece-nos ser, de fato, uma espécie de rebaixamento, de que sua obra foi, a partir da geração de 70, vítima" (1999, p. 99). Concordamos com Cleonice Berardinelli, que defende a utilização do termo "romance" para a produção fíccional camiliana: "[...] a suas obras chamou Camilo romances; romances chamar-lhes-ei eu, certa de que ele não faz distinção entre os dois significantes [romance e novela]." (1994, p. 225, grito da autora). A nosso ver, o uso do termo "romance" para designar a ficção de Macedo pode ser justificado da mesma forma. Sabemos que o significado deste termo é também fluido, tendo sido alvo de diversos estudos e teorias; segundo alguns desses estudos, é possível encontrarmos definições que não se apliquem às produções camiliana e macediana. Entretanto, por mais que, em algumas obras desses autores, a escolha do termo "romance" possa vir a ser contestada, acreditamos na pertinência de utilizá-lo neste trabalho, uma vez que é nosso intuito propor o resgate e a revalorização da ficção de Camilo e de Macedo.
}

${ }^{2}$ Optamos por atualizar a ortografia de todos os termos e citações utilizados neste trabalho seguindo o Novo Acordo Ortográfico vigente desde 2009, uma vez que a sua escrita não interfere na análise que aqui pretendemos realizar.

\footnotetext{
${ }^{3}$ Numa rápida pesquisa por sites de venda on-line como o da Livraria Cultura, encontramos 14 edições de Amor de Perdição disponíveis à venda (ou seja, excetuando-se as que se encontram esgotadas), publicadas por editoras diferentes (entre elas, destaca-se a Ática, que em 2010 lançou a 30 a edição do romance português), além de quatro e-books e dois audiolivros. Coincidentemente, verificamos que A Moreninha também se encontra disponível nesse site em 14 edições distintas, publicadas por editoras diversas (sua publicação pela Ática já se encontra na $36^{a}$ edição, lançada em 2012), além de três e-books e um audiolivro. Tais dados, recolhidos de maneira informal no dia 22 de janeiro de 2013, mostram que Camilo e Macedo ainda são autores de apelo comercial em pleno século XXI - uma vez que, se não vendessem, as editoras não se ocupariam em relançar novas edições para esses livros, inclusive nas novas plataformas digitais.
} 
lidos pelos alunos, sabemos que, pelo menos, são adotados pelas escolas, e que, portanto, ainda fazem parte do cânone.

Outro dado que mostra a sobrevivência desses autores no imaginário lusobrasileiro é a penetração que tiveram nas outras artes. Amor de Perdição foi adaptado em quatro filmes (produzidos em Portugal em 1921, 1943, 1978 e 2008), uma telenovela (produzida no Brasil em 1965) e duas óperas (uma que estreou em 1907 e foi encenada novamente em 2008, e outra em 1991), além de várias representações teatrais ${ }^{4}$. Já $A$ Moreninha foi adaptada em dois filmes (produzidos em 1915 e 1970), duas telenovelas (uma produzida em 1965 e outra em 1975, a qual foi reapresentada em 1976 e, novamente, em 1982), uma ópera (encenada em 1979), além de espetáculos teatrais diversos.

Assim sendo, verificamos que o romance camiliano, tido pela historiografia literária como "a quinta essência do lirismo passional” (1941, p. 283), nas palavras de Fidelino de Figueiredo em Literatura Portuguesa, é considerado a obra mais importante do escritor português, cuja “figuração romanesca de uma dada concepção de vida fez correr imensas lágrimas às nossas avós ou trisavós" (1996, p. 791), de acordo com António José Saraiva e Óscar Lopes na clássica História da Literatura Portuguesa, publicada em 1955. Segundo João Soares Carvalho, na mais recente História da Literatura Portuguesa, de 2003, Camilo teria "atingido o seu zênite nos chamados romances passionais, como Amor de Perdição" (2003, p. 357).

Em A Literatura Brasileira (1999), por sua vez, José Aderaldo Castello defende que "a grande contribuição que ele [Macedo] nos deu, em termos destacados da sensibilidade brasileira, já com características definidamente românticas, é representada particularmente pela ingenuidade e pureza sentimental de A Moreninha" (1999, p. 236), obra que teria dado “origem a um mito sentimental, a Moreninha, padroeira de namoros que ainda faz sonhar as

\footnotetext{
${ }^{4}$ Conforme aponta o levantamento realizado por Gilda Santos (2012, p. 37-39), em Amor Sem Perdição: Camilo e o Real Gabinete Português de Leitura.
} 
adolescentes" (2007, p. 454), segundo a Formação da Literatura Brasileira, publicada por Antonio Candido em 1959. Para José Veríssimo, na História da Literatura Brasileira, de 1916, “os romances de Macedo são todos talhados por um só molde. São ingênuas histórias de amor, ou antes de namoro [...]. [Nelas] carrega o autor no romanesco, exagera a sentimentalidade até a pieguice [...]" (1963, p. 173).

Tais definições justificam a presença desses autores no capítulo sobre o romantismo ou, ainda, o ultrarromantismo, nas diversas histórias de literatura portuguesa e brasileira, apesar de terem publicado entre as décadas de 1840 e 1880 , e, portanto, terem vivido durante o período romântico e o realista - cujas barreiras são, de fato, difusas, uma vez que o romance realista francês já era lido no Brasil e em Portugal nos primórdios do romantismo. Sabemos que as histórias de literatura, aliás, pouco diferem entre $\mathrm{si}^{5}$, uma vez que apresentam uma mesma lista de escritores e obras escolhidas - o cânone -, além de uma mesma leitura para essas obras - a canônica.

Roberto Reis explica que a historiografia literária é "ainda bastante norteada pelo conceito estético dos "estilos de época"' (1992, p. 80), o que acaba servindo como critério de seleção para a entrada no cânone - pertence ao cânone aquele autor que puder ser encaixado em determinado "estilo de época"; aquele que constitui um desvio é automaticamente excluído -, ditando também a leitura das obras, presas pelos limites que o rótulo do "estilo de época" do qual supostamente fazem parte acaba impondo. Além disso, segundo o teórico,

\footnotetext{
${ }^{5}$ Ressalvamos que não é nosso intuito aqui depreciar a historiografia literária, uma vez que, como afirma Vítor Aguiar e Silva no prefácio a A Construção do Discurso da História Literária na Literatura Portuguesa do Século XIX, de Carlos Manuel Ferreira da Cunha, "[...] a história literária desempenhou um papel central nos estudos literários e, mais alargadamente, no que se poderá denominar a cultura literária dos séculos XIX e XX: contribuiu decisivamente para a relevância cultural, social e política da literatura ao longo do século XIX e do século XX; possibilitou conhecer, no sentido originário da palavra, a tradição das literaturas europeias, revelando a existência e o significado de obras, de autores, de épocas, escolas e correntes literárias de que pouco ou nada se sabia; legitimou, com o seu estatuto de ciência da literatura, a entrada nas Universidades europeias e norte-americanas do ensino da literatura, em particular das chamadas literaturas 'modernas'." (2002, p. 6, grifo do autor). Entretanto, não podemos negar que a historiografia literária tem sido a grande responsável pela perpetuação de determinadas leituras estereotipadas para as produções de alguns autores.
} 
um número expressivo de histórias literárias e de estudos sobre a literatura brasileira está orientado por um paradigma nacionalista e um vetor teleológico: a crítica, engajada num processo de "emancipação" da cultura brasileira da dependência que a tem acossado desde os tempos coloniais, projeta a sua ideologia no corpus literário e como que tende a avaliar os textos e escritores em função do grau maior ou menor de "nacionalidade" que porventura contenham. (1992, p. 80-81).

A questão da nacionalidade é também imprescindível para os estudos literários em Portugal, tendo-se em vista a importância, por exemplo, da reflexão de Eduardo Lourenço sobre a construção da identidade portuguesa. Para Vítor Aguiar e Silva,

\begin{abstract}
A história literária romântica [precursora da historiografia literária tal como a conhecemos] é indissociável dos conceitos de povo, de nação e de identidade nacional, pois que a língua e a respectiva literatura são consideradas como as expressões mais profundas e autênticas do espírito de um povo e de uma nação, assim como é indissociável do conceito fantasmático de espírito da época, ou seja, o conjunto de ideias, de sentimentos, de valores e de aspirações que explicaria o processo dos acontecimentos históricos num determinado período de tempo. (2002, p. 4).
\end{abstract}

É o viés nacionalista que embasa um elogio como o que Saraiva e Lopes fizeram acerca de Camilo: "a sua obra traz até nós o palpitar humano das províncias nortenhas no seu tempo, com uma vida que nenhum outro ficcionista voltou a captar” (1996, p. 779). Tal análise é semelhante à feita por Afrânio Coutinho e J. Galante de Sousa, sobre Macedo, na Enciclopédia de Literatura Brasileira, de 1990: segundo os críticos, "ninguém lhe pode negar [...] o caráter essencialmente brasileiro da obra [...], o senso de observação dos nossos costumes, [...] a exatidão do retrato da sociedade de uma época que foi a sua e da qual ele é indiscutivelmente, no terreno da ficção, o mais fiel fotógrafo" (2001, p. 984).

Ao sentimentalismo e ao nacionalismo soma-se a imagem depreciativa de escritores comerciais ${ }^{6}$, voltados ao entretenimento, pautada pelas tentativas dos autores de

\footnotetext{
${ }^{6}$ Camilo e Macedo também receberam da historiografia literária o rótulo de escritores moralistas. Segundo João Soares Carvalho, "os seus ideais [de Camilo] de escritor oscilam entre a adoção de um idealismo moralizante [...]
} 
viverem de sua pena - Camilo, nesse sentido, foi mais feliz do que Macedo, que teve de conjugar o ofício literário com outros tipos de trabalho ${ }^{7}$. Tal imagem é também baseada no fato de esses autores terem publicado uma produção vasta e diversa - Camilo publicou 137 títulos, distribuídos em 180 volumes, entre romances, contos, poemas, peças de teatro, traduções, histórias e críticas literárias (Cf. FRANCHETTI, 2003, p. IX-L); Macedo escreveu vinte romances, doze peças de teatro, um poema e mais de dez volumes de variedades (Cf. CANDIDO, 2007, p. 454) -, que curiosamente acabou sendo apagada em detrimento da sobrevivência e da supervalorização de A Moreninha e Amor de Perdição.

João Soares Carvalho afirma que "Camilo não tem obras de grande profundidade" (2003, p. 389); segundo o crítico, o autor, "tendo de escrever para viver, não teve tempo para fazer uma boa e desejável observação das pessoas e das coisas, usando apenas a sua genial

e um realismo igualmente moralizante" (2003, p. 343). Para Antonio Candido, "não é também de espantar que a sua visão [de Macedo] seja tão pobre, e de quase todos os seus livros se desprenda uma boa vontade cheia de bonomia e otimismo. [...] A maldade [nas suas obras] é provisória, o bem, definitivo: eis a moral dos seus livros. Nunca escritor reduziu tanto a psicologia à moral, e esta ao catecismo" (2007, p. 460). Segundo esse ponto de vista, o suposto moralismo que regeria as produções de Camilo e de Macedo adquire uma feição de "defeito", que empobreceria o seu valor literário. No entanto, de acordo com Valéria Augusti, "ao analisar negativamente a dimensão moral das obras do autor [Macedo], a crítica literária do século XX perdeu de vista que essa mesma dimensão moral era, no século XIX, extremamente valorizada em um romance" (1998, p. 97). De acordo com a pesquisadora, "[...] os críticos contemporâneos ao lançamento de A Moreninha [...] consideravam que um bom romance deveria, necessariamente, servir à moralização do público leitor. Nesse contexto, é possível supor que a função moralizadora deveria ser, em grande medida, um objetivo perseguido pelo autor. Desse ponto de vista, o caráter moral dos romances macedianos, com frequência observado pela crítica, provavelmente não seria resultado de uma disposição 'pessoal' do autor, mas sim, de uma certa convenção acerca do que deveria ser um romance naquele momento" (1998, p. 113). Apesar de concordarmos com a hipótese de Augusti - que também pode ser aplicada ao contexto de produção de Camilo -, de que a defesa da moral era apreciada por grande parte do público oitocentista, acreditamos que o suposto moralismo macediano pode ser questionado em algumas de suas obras, como As Mulheres de Mantilha, que iremos discutir no capítulo 6.2. No caso da ficção camiliana, o intuito moralizante dos romances é muitas vezes ridicularizado pelo narrador, como apontamos em nossa Dissertação de Mestrado, intitulada Entre o Coração e o Estômago: o olhar distanciado de Camilo Castelo Branco, defendida na Universidade de São Paulo em 2009. Como defendemos naquela ocasião, Camilo não parece ter um propósito didático, se verificarmos as sentenças com as quais termina A Queda dum Anjo - "Fica sendo, portanto, esta coisa uma novela que não há de levar ao céu número de almas mais vantajoso que o do ano passado" (1986, p. 1005) - e A Brasileira de Prazins - "[...] o meu romance não pretende reorganizar coisa nenhuma. E o autor desta obra estéril assevera, em nome do patriarca Voltaire, que deixaremos este mundo tolo e mau, tal qual era quando cá entramos" (1988, p. 852, grifo do autor). Retomaremos algumas dessas questões ao longo de nossa análise.

${ }^{7}$ De acordo com Tania Rebelo Costa Serra, Macedo "só escrevia à noite, ficando até duas ou três horas da manhã criando [...]. Depois, fazia a revisão dos manuscritos, segundo depoimento de alunos do Colégio Pedro II, enquanto os mandava desenhar mapas no quadro negro, concentrando-se inteiramente em corrigir aqueles trabalhos. Era, aparentemente, o único tempo livre que tinha para fazê-lo. Trabalhava quase sem parar, portanto" (2004, p. 106). A dependência de empregos públicos poderia explicar o esforço de Macedo em preservar a face em determinados momentos de crítica social e política, em contraposição ao tom cáustico de Camilo. 
imaginação, subordinada a temas corriqueiros, folhetinescos, que ia repetindo, numa lamentável monotonia" (2003, p. 389). Saraiva e Lopes corroboram esta ideia, ao declarar que Camilo, “dependendo quase exclusivamente do seu trabalho literário, não pôde nunca dar-se ao gosto de construir um romance de fôlego, fervente de caracteres e ambientes, que eliminasse os atrativos folhetinescos e a retórica sentimental” (1996, p. 779). A imagem consagrada na Introdução ao Estudo da Novela Camiliana, de Jacinto do Prado Coelho, considerada a maior referência para os estudos camilianistas, apesar de não ser negativa, mostra o caminho comumente seguido por parte da crítica. Para Prado Coelho, "a novela camiliana é, pois, uma novela de aventuras, para recrear a imaginação, e de conflitos dramáticos, para fazer vibrar a sensibilidade" (2001, p. 393); em outro momento, ele reafirma: "novelas, disse eu, romanescas. Na verdade, a novela camiliana típica, reduzido o enredo a esquema, não passa duma história passional para sacudir os nervos e entreter a imaginação do leitor" (2001, p. 465).

A leitura que Antonio Candido, um de nossos mais importantes críticos, apresenta na Formação da Literatura Brasileira ressalta as qualidades de Macedo de maneira que nos fica a impressão de serem na verdade características negativas, e não positivas - como mostra a insistência aparentemente carinhosa na alcunha "Macedinho", que de fato se relaciona a, citando as palavras do crítico, um "pequeno valor literário da sua obra" (2007, p. 454). "Pequeno" é, aliás, um adjetivo que se repete ao longo de seu texto acerca de Macedo. Segundo Candido, o autor brasileiro teria cultivado uma "fidelidade ao real" que o teria levado a "alicerçar as suas ingênuas intrigas sentimentais com fundamentos bem assentados no interesse econômico [...], desvendando alguns mecanismos essenciais da moral burguesa [...]” (2007, p. 456). O que poderia ser uma qualidade de sua obra, entretanto, fica obliterado pelo fato de as intrigas sentimentais serem "ingênuas" e terem como base o que ele chama de "pequeno realismo" (2007, p. 455), exercendo uma "vocação coloquial” (2007, p. 457) que 
teria reforçado, "por outro lado, a sua mediocridade" (2007, p. 457). No início do capítulo, Candido já havia deixado claro o seu posicionamento em relação a Macedo: para ele, o autor nada teria a oferecer além de enredos fáceis e ingênuos:

Outros [escritores], todavia, parecem preocupar-se, não tanto com a sua mensagem, quanto com a possibilidade receptiva do leitor, a cujos hábitos mentais procuram ajustar a obra, sem grande exigência. Neste caso, a sua força não provém da singularidade do que exprimem, mas do fato de saberem fornecer ao leitor mais ou menos o que ele espera, ou é capaz de esperar. A facilidade com que o leitor apreende o texto é, geralmente, o índice de conformidade deste com as possibilidades médias de compreensão e as expectativas do meio [...]. Não poderíamos encontrar no Brasil, em todo o século passado [XIX], escritor mais ajustado a esta via de comunicação fácil do que Joaquim Manuel de Macedo. (2007, p. 453-454).

Apesar de sua imprescindível contribuição para os estudos literários brasileiros,

Candido acabou sendo responsável pela perpetuação de uma imagem negativa da obra macediana, que encontra ecos numa crítica mais recente. Luiz Roncari, por exemplo, na Literatura Brasileira publicada em 1995, é incisivo: segundo ele, “com A Moreninha, o romance começa no Brasil pela sua pior vertente, que depois será a dominante nas telenovelas, criando uma falsa imagem do país e de sua formação social” (2002, p. 535). Para o crítico,

Se o gênero romance possibilitou ao escritor uma perspectiva ótima para observar o homem e o seu mundo social próximos, assim como representálos nas suas relações rotineiras e profundas, ele permitiu também que muitos autores o usassem para estilizar e suavizar a imagem do mundo social representado e, com isso, os leitores fizessem dele um meio de evasão e fuga do real.

Seguindo este último caminho, o romance deixava de ser, tanto para o autor quanto para o leitor, um meio de revelação e conhecimento (ou, pelo menos, de dúvida e inquietação, como acontece com as melhores obras do gênero), para se transformar num passatempo, instrumento de ilusão. Foi esta a opção de Joaquim Manuel de Macedo [...]. O segundo caminho seria o de ficar na superfície das suas observações [...], e trabalhar a trama, o enredo que prendia a atenção do leitor, interessado apenas em saber se os amantes venceriam ou não os obstáculos colocados à realização do amor. Esse foi o caminho escolhido por Macedo. (2002, p. 532, grifo do autor). 
Devemos ter um olhar cauteloso para tais acepções, uma vez que podem carregar juízos de valor questionáveis - como a premissa de que a literatura de massa ${ }^{8}$ carece de profundidade e, portanto, é indigna de uma análise mais detida. Segundo essa premissa, os mass media, "feitos para o entretenimento e o lazer, são estudados para empenharem unicamente o nível superficial da nossa atenção" (ECO, 1970, p. 41). Parte dos estudos literários nutre certa ojeriza em relação à literatura de entretenimento porque a colocam em oposição à "alta literatura", que supostamente seria destruída, juntamente com os seus valores, pela cultura de massa. Assim, o papel da literatura - e, mais precisamente, do crítico - seria hipoteticamente "preservar um mundo de valores contra a selva da cultura de massas" (CEVASCO, 2003, p. 142), utilizando-se, para isso, do cânone, "um perene e exemplar conjunto de obras [...], um patrimônio da humanidade” (REIS, R., 1992, p. 70), as quais supostamente "contêm verdades inquestionáveis, atemporais e universais, transcendem o seu momento histórico e fornecem um modelo a ser seguido" (REIS, R., 1992, p. 71).

É por isso que Amor de Perdição e A Moreninha são aclamados por seu sentimentalismo - o amor, afinal, teria um valor "atemporal e universal", além de ser tema majoritário do romantismo, "estilo de época" em que Camilo e Macedo são rotulados. E é também por esse motivo que, paradoxalmente, esses autores são vistos de forma negativa por alguns críticos, uma vez que escreviam romances de folhetim - um dos primeiros veículos da cultura de massa -, gênero que possui um viés claramente comercial, pois a sua receptividade

\footnotetext{
${ }^{8}$ Como sabemos, nos meados do século XIX somente uma pequena parcela da população portuguesa e brasileira era alfabetizada e tinha acesso aos romances de folhetim - com exceção dos centros urbanos, que reuniam uma porcentagem maior de alfabetizados e que constituíam o principal mercado consumidor de literatura, composto, sobretudo, pelas camadas médias da população (formadas pelos profissionais liberais e funcionários públicos) e pelos grandes proprietários (principalmente suas esposas e seus filhos, geralmente rapazes estudantes e moças casadouras). No entanto, parece-nos adequado falar em uma incipiente "literatura de massa", uma vez que, como afirma José Ramos Tinhorão, o folhetim romântico transformou-se "na primeira expressão ficcional realmente de massa da era moderna" (1994, p. 9), atingindo um maior número de pessoas e adquirindo estatuto de mercadoria, culminando nas edições populares de grande tiragem, a preços módicos, que passaram a ser consumidas até mesmo pelas camadas mais baixas da população, nos anos finais do século XIX, como foi estudado por Alessandra El Far em Páginas de Sensação: literatura popular e pornográfica no Rio de Janeiro (1870-1924).
} 
perante o público muitas vezes ditava a venda dos jornais, havendo, assim, a necessidade de agradar ao leitor fornecendo o entretenimento que ele desejava.

De acordo com Umberto Eco, no entanto, “a indústria editorial distingue-se da dos dentifrícios pelo seguinte: nela se acham inseridos homens de cultura, para os quais o fim primário (nos melhores casos) não é a produção de um livro para vender, mas a produção de valores" (1970, p. 50). Dessa forma, “ao lado de 'produtores de objetos de consumo cultural', agem 'produtores de cultura' que aceitam o sistema da indústria do livro para fins que dele exorbitam" (1970, p. 50). É necessário também pontuarmos que a barreira entre a "alta cultura" e a cultura de massa não é tão clara como alguns críticos a supõem. Utilizando-nos das palavras de Eco, "creio que possa existir um romance entendido como obra de entretenimento (bem de consumo), dotado de validade estética e capaz de veicular valores originais" (1970, p. 56). Além disso,

a diferença de nível entre os vários produtos não constitui a priori uma diferença de valor, mas uma diferença da relação fruitiva, na qual cada um de nós alternadamente se coloca [...]. Cada um de nós pode ser um e outro, em diversos momentos de um mesmo dia, num caso, buscando uma excitação do tipo altamente especializada, no outro, uma forma de entretenimento capaz de veicular uma categoria de valores específica. (ECO, 1970, p. 58).

Márcia Abreu, ao estudar o mercado editorial brasileiro oitocentista, chegou a conclusões similares. Segundo a pesquisadora,

Assim como os críticos tinham avaliações díspares sobre os textos, os leitores cariocas tinham um gosto suficientemente elástico para apreciar os mais variados tipos de romance. Buscavam os mais antigos como a História do Imperador Carlos Magno e dos doze pares de França, que carregava a pecha de romance romanesco. Cheio de lances fabulosos e intervenções maravilhosas, conta a história do primeiro rei católico da França, narrando as batalhas em que se envolve junto com seus companheiros no enfrentamento de gigantes e mouros e os auxílios e instruções que recebem dos céus. Ao mesmo tempo, mostravam interesse pela mais demolidora sátira a esse tipo 
de romance: Don Quijote de la Mancha, de Miguel de Cervantes Saavedra. (2003, p. 333-334).

Assim sendo, se a leitura canônica acaba constituindo um obstáculo para a análise, no nosso caso, das obras de Camilo e Macedo - que acabam limitadas às definições de "sentimentalismo", "nacionalismo" e "entretenimento (alienado)" -, é necessário lançarmos mão de outros instrumentos. Nesse sentido, os estudos culturais se mostram muito úteis, pois “questionam a produção de hierarquias sociais e políticas a partir de oposições entre [...] níveis de cultura - por exemplo, alta e baixa, cultura de elite e cultura de massa. A consequência natural desse debate é a revisão dos cânones estéticos" (ESCOSTEGUY, 2001, p. 41). Para isso, temos de "mudar não só o que se estuda, mas também, de forma crucial, como se estuda" (CEVASCO, 2003, p. 148), ou seja, não podemos estudar apenas aquilo que está no cânone - no caso de Camilo e Macedo, Amor de Perdição e A Moreninha -, nem podemos nos ater à leitura canônica, comumente feita destas obras. Como afirma Maria Elisa Cevasco, “o materialismo cultural não considera os produtos da cultura 'objetos', e sim práticas sociais; o objetivo da análise materialista é desvendar as condições dessa prática e não meramente elucidar os componentes de uma obra” (2003, p. 148).

É importante, antes de tudo, pontuarmos que a leitura canônica pode, de fato, ser fundamentada nas obras de Camilo e Macedo, uma vez que estas possuem, em sua maioria, uma temática sentimental e uma ambientação de viés, por vezes, nacionalista, além de terem sido escritas para serem vendidas e consumidas como entretenimento. A nosso ver, no entanto, muitos desses romances são, na acepção de Ítalo Calvino, clássicos, uma vez que, apesar da visão sedimentada que encontramos nas histórias literárias, “quando são lidos de fato mais se revelam novos, inesperados, inéditos" (1993, p. 12), nunca terminando "de dizer aquilo que tinha[m] para dizer" (1993, p. 11). 
Contudo, chama-nos a atenção o fato de Camilo e Macedo serem lembrados apenas por seus supostos momentos passionais e melodramáticos - Camilo por Amor de Perdição e Macedo por A Moreninha -, apesar da comicidade existente em suas obras, que além de provocarem o riso, também incitam à reflexão. Ao tratar do romance camiliano, Paulo Franchetti nos dá uma possível explicação para esse esquecimento, que também pode ser aplicada a Macedo:

Um dos pontos centrais da tradição [...] dos estudos camilianos é a ênfase nos aspectos narrativos em detrimento dos aspectos ligados à enunciação, à constituição da figura autoral, à reflexão sobre a materialidade do texto; em detrimento, portanto, das várias formas de metalinguagem. Junto com essa ênfase na matéria narrada, caminha a valorização dos ambientes sociais e naturais que aí comparecem. O ponto de excelência é não apenas a fidelidade do retrato, mas também a integração dos elementos sociais e naturais na composição de um enredo econômico. Amor de Perdição, nesse discurso, é valorizado porque aí tudo está a serviço da unidade de ação. (2003, p. XVII).

Dessa forma, depreendemos que a imagem estereotipada de Camilo foi formada a partir da análise superficial de seus enredos, pouco se tratando "até muito recentemente - a não ser como defeitos ou excrescências - tanto das divagações filosóficas quanto da sua escrita metalinguística ou do artifício das suas locuções, ou seja, a utilização específica que ele faz da língua e das formas narrativas" (FRANCHETTI, 2003, p. XX). Como sabemos, o mesmo acontece com Macedo: até Antonio Candido, por exemplo, considera os comentários do narrador macediano como frutos de "um impulso irresistível de tagarelice" (2007, p. 454). Talvez não seja inconveniente fazermos a seguinte pergunta: por que um procedimento estético tão valorizado em Machado de Assis é considerado um "defeito" em Camilo e “tagarelice” em Macedo?

Devemos, por isso, perguntar-nos se os romances camilianos e macedianos não têm sido vítimas de uma leitura pautada em certas imagens cristalizadas, que acabam dificultando um trabalho de análise mais aprofundado, que, por sua vez, poderia revelar 
algumas surpresas. Apesar de terem recebido um pouco mais de atenção da crítica especializada nos últimos $\operatorname{anos}^{9}$, parece-nos ser necessário reforçar a importância de uma análise mais detida das obras desses autores, a fim de abarcar alguns elementos comumente ignorados ou relegados a segundo plano, que podem vir a trazer novas perspectivas de leitura sobre eles.

Por outro lado, a aproximação entre Camilo e Macedo, escritores de uma mesma geração - ambos nasceram na década de 1820, começaram a publicar nos anos 1840 e faleceram com idades próximas: o primeiro, em 1890, com 65 anos, e o segundo em 1882, aos 62 anos -, ainda está por ser feita. Tania Rebelo Costa Serra, em seu livro Joaquim Manuel de Macedo ou os Dois Macedos: a luneta mágica do segundo reinado, apenas cita a semelhança biográfica ${ }^{10}$ entre eles. Segundo ela, os dois escritores, consagrados no início de suas carreiras e no final "esquecidos ${ }^{11}$ na miséria", teriam sido "atropelados" pelo sucesso da escola realista: “o caminho para o ocaso desse homem [Macedo] que fora tão famoso, tão semelhante ao de um outro romancista romântico de além-mar, Camilo Castelo Branco, derrapa ladeira abaixo [...]. Camilo mete uma bala na cabeça; Macedo enlouquece” (2004, p. 228). A semelhança

\footnotetext{
9 Renomados críticos portugueses, como Aníbal Pinto de Castro e Carlos Reis - que, junto a Maria da Natividade Pires, propôs, no volume sobre o romantismo na História Crítica da Literatura Portuguesa (1993), uma leitura diferenciada do comumente encontrado na historiografia literária -, além de pesquisadores brasileiros, como Paulo Motta Oliveira, têm se dedicado a estudar a obra de Camilo, destituindo-a de sua imagem sedimentada, o que constitui uma importante renovação na crítica camilianista. A obra de Macedo, por sua vez, tem sido mais investigada desde a publicação de Joaquim Manuel de Macedo ou os Dois Macedos: a luneta mágica do segundo reinado (1994) por Tania Serra, que resgatou o estudo que Temístocles Linhares publicou inicialmente na Revista do Livro (entre 1958 e 1960) e posteriormente na História Crítica do Romance Brasileiro (1987) - que constitui uma exceção, no que concerne à ficção de Macedo, entre as usuais histórias de literatura brasileira -, propondo uma releitura de toda a produção macediana. Destacam-se também os estudos conduzidos por pesquisadores do projeto Caminhos do Romance, que têm contribuído para uma revalorização da trajetória de Macedo.
}

${ }^{10}$ Optamos por não abordar neste trabalho aspectos biográficos dos dois autores, uma vez que tais pormenores não se relacionam com a análise que aqui pretendemos fazer. A biografia de Camilo, principalmente - cuja vida extremamente "romanesca" é utilizada por críticos camilianistas renomados, como Alexandre Cabral, enquanto chave de interpretação de seus romances -, ainda é muito empregada na análise de sua obra, que, a partir desse tipo de leitura, acaba perdendo grande parte de seu valor literário. Como pretendemos resgatar esse valor, acreditamos na relevância de se estudar tanto a ficção camiliana quanto a macediana sem relacioná-las com as suas biografias.

${ }^{11}$ Tal acepção é questionável tendo-se em vista as suas vendas durante o chamado período realista/naturalista, fato que iremos discutir ao longo deste trabalho. 
literária, no que concerne aos temas tratados e aos procedimentos narrativos utilizados pelos dois escritores, contudo, ainda não foi trabalhada, lacuna que pretendemos preencher com este trabalho.

A nosso ver, o interesse em estudar a ficção dos dois escritores reside no fato de que ambos viveram no mesmo período, um em Portugal e outro no Brasil, tendo iniciado e encerrado as suas carreiras literárias na mesma época. Através da análise de suas obras, publicadas ao longo de quatro décadas, durante o período classificado como romântico pela historiografia literária e o período seguinte, denominado de realista/naturalista, é possível depreendermos parte importante do processo de ascensão do romance nos dois países, que compartilham mais similaridades do que diferenças, como pretendemos explicar no capítulo seguinte. Além disso, Camilo e Macedo possuem uma vasta produção, que abarca alguns dos principais subgêneros do romance ${ }^{12}$ em voga no século XIX, que serão aqui trabalhados, a fim de buscarmos compreender a ficção oitocentista em sua diversidade. Como defende Franco Moretti,

[...] o romance é, em suma, o conjunto dos seus subgêneros [...]. as grandes teorias do romance [...] reduziram o romance a uma só forma de base (o realismo, o romance, o dialogismo, o metarromance). E se esta redução lhe conferiu elegância conceitual e força teórica, terminou também por fazer desaparecer nove décimos da história literária. É muito. (2008, p. 57, grifo do autor).

\footnotetext{
${ }^{12}$ Sabemos que o gênero romance é híbrido, caracterizado pela mistura de vários elementos. Entretanto, as obras possuem aspectos que se sobressaem entre outros, permitindo a classificação, por exemplo, de um romance como histórico, apesar de este poder possuir características do romance sentimental e da narrativa fantástica. Como explica Tzvetan Todorov, "é porque os gêneros funcionam como uma instituição que eles funcionam como 'horizontes de expectativa' para os leitores, e como 'modelos de escrita' para os autores [...]. Por um lado, os autores escrevem em função do (o que não significa de acordo com o) sistema genérico existente, que eles podem demonstrar tanto dentro do texto quanto fora dele, ou mesmo, em certo sentido, entre os dois: na capa do livro. [...] Por outro lado, os leitores leem em função do sistema genérico, com o qual estão familiarizados através da crítica, da escola, do sistema de distribuição do livro, ou simplesmente de ouvirem falar." (tradução nossa do trecho: "it is because genres exist as an institution that they function as 'horizons of expectation' for readers, and as 'models of writing' for authors [...]. On the one hand, authors write as a function of (which does not mean in accord with) the existing generic system, which they can demonstrate both within the text and outside it, or even, in a way, between the two: on the cover of the book. [...] On the other hand, readers read as a function of the generic system, with which they are familiar through criticism, school, the distribution system for the book, or simple hearsay." [1976, p. 163]). Esclarecemos ainda que optamos por utilizar o termo "subgênero" para nos referirmos aos tipos de romance simplesmente porque se tratam de subdivisões do gênero romance; para nós, o prefixo "sub" não é aqui utilizado com o sentido de "inferior".
} 
Sendo assim, com o intuito de alcançarmos uma visão panorâmica e mais completa e abrangente da ficção de Camilo e Macedo, optamos por analisar exemplares dos diversos subgêneros romanescos consumidos pelos leitores oitocentistas. Para isso, propomos no terceiro capítulo uma releitura dos best-sellers Amor de Perdição e A Moreninha, representantes, a princípio, do romance sentimental. Em seguida, trabalharemos com as narrativas de viagem Vinte Horas de Liteira e A Carteira de Meu Tio. No capítulo quinto, faremos a análise das narrativas fantásticas $O$ Esqueleto - além de alguns contos camilianos e A Luneta Mágica. No capítulo seguinte, iremos estudar o romance histórico, representado por O Demônio do Ouro e As Mulheres de Mantilha - obra cuja temática nos fez pensar também num subcapítulo à parte, sobre As Três Irmãs, de Camilo. Por fim, analisaremos os romances $O$ Senhor Ministro e As Vítimas-Algozes, que possuem características naturalistas, ou, segundo alguns críticos, pré-naturalistas.

Dessa forma, pretendemos contribuir para os estudos comparados de literaturas de língua portuguesa, através de uma aproximação, ainda não trabalhada pela crítica, entre Camilo, escritor português, e Macedo, brasileiro. Por outro lado, procuramos também contribuir para os estudos oitocentistas, relacionando a análise das produções ficcionais desses autores com os processos de ascensão do romance em Portugal e no Brasil, que, apesar de terem ocorrido de forma distinta nos dois países, compartilharam muitas semelhanças, por terem sido ambos países periféricos em relação aos centros do capitalismo europeu. 


\section{A ascensão do romance nas periferias do capitalismo}

Camilo Castelo Branco e Joaquim Manuel de Macedo foram, como sabemos, dois dos escritores protagonistas da ascensão do romance em Portugal e no Brasil, respectivamente. Com o grande sucesso que acompanhou a publicação de A Moreninha, em 1844, Macedo é considerado por grande parte da historiografia literária o inaugurador do romance em solo nacional - apesar de escritores brasileiros terem se aventurado no gênero desde a década de 1820 (Cf. MEYER, 1996, p. 48). No entanto, não foi apenas A Moreninha que conquistou a simpatia do público, tendo dez edições até 1899, como explicamos anteriormente: $O$ Moço Loiro e Rosa tiveram seis edições, cada um, até o final do século XIX; A Carteira de Meu Tio teve cinco edições; Os Dois Amores, Vicentina e O Forasteiro, quatro edições cada um; e Os Romances da Semana e A Baronesa de Amor, três edições cada (Cf. SERRA, 2004, p. 325-353).

Em sua pesquisa nos catálogos dos livros da Biblioteca Fluminense e do Gabinete Português de Leitura, de meados da década de 1850, e do catálogo da Biblioteca Nacional, de vinte anos depois, Valéria Augusti constatou a presença de muitos romances de Macedo, o que mostra que o autor permaneceu no gosto dos leitores durante todo esse período. Como ela afirma,

Os catálogos evidenciam a presença marcante das obras macedianas nas bibliotecas do século XIX. É evidente que essa disponibilidade da produção literária do autor não nos dá nenhuma certeza sobre a leitura de suas obras mas, sem dúvida, faz-nos crer que havia leitores suficientes a ponto de justificar a presença dos romances mais recentes de Macedo no acervo da Biblioteca Pública Municipal. [...] Consideradas as datas dos exemplares pertencentes a essa biblioteca, podemos dizer que em seu acervo o leitor podia encontrar as mais recentes edições desse autor. Esses registros colocam dúvidas acerca de certas afirmações segundo as quais Macedo já estaria, nos idos da década de 50, em franca decadência junto ao público leitor. (1998, p. 108-109). 
Além disso, o autor foi uma personalidade importante no meio intelectual e artístico nacional durante o século XIX - como indica a sua quase onipresença nos volumes II, III e IV da História da Inteligência Brasileira, de Wilson Martins -, tendo participado, juntamente com Gonçalves Dias e Manuel de Araújo Porto-Alegre, da fundação da Revista Guanabara, além de ter sido deputado pelo Partido Liberal, preceptor dos filhos da Princesa Isabel e secretário e orador do Instituto Histórico e Geográfico Brasileiro. Segundo Sílvio Romero, crítico que conheceu o escritor em vida, "por trinta anos seguidos [...], [Macedo] fez rir a este Rio de Janeiro [...], e foi o mais lido, o mais espalhado de todos os escritores nacionais. [...] Como quer que seja, Macedo foi um dos homens que mais escreveram no Brasil” (1960, p. 1401).

Camilo, por sua vez, apesar de ter iniciado a sua carreira literária depois que Almeida Garrett e Alexandre Herculano já eram nomes consagrados, foi o primeiro escritor profissional português a viver de sua pena, tendo contribuído para a formação de um mercado editorial no país, a partir de sua vasta e diversificada produção. Sua obra de estreia Maria! Não me mates, que sou tua mãe! foi um dos quatro maiores best-sellers do romantismo português, conforme apurou a pesquisa de Luís Sobreira ${ }^{1}$, tendo tido quatro edições somente entre 1848 e 1852. Como mostramos no capítulo anterior, Amor de Perdição teve dez edições até o final do século XIX; já Mistérios de Lisboa teve seis edições; Livro Negro de Padre Dinis, Onde Está a Felicidade e $O$ Bem e o Mal tiveram cinco edições cada um; Anátema, A Filha do Arcediago, A Neta do Arcediago, Carlota Ângela, As Três Irmãs, Estrelas Funestas,

\footnotetext{
1 “[...] o levantamento bibliográfico realizado ['em jornais da época, em catálogos de gabinetes de leitura e de livrarias, em obras de crítica literária, em dicionários bibliográficos, em histórias da literatura e nos ficheiros da Biblioteca Nacional de Lisboa, e que procurou ser o mais exaustivo possível [...]'] serviu, principalmente, para identificar as obras que gozaram de maior aceitação, mediante o número de edições que tiveram e o espaço de tempo que decorreu entre as várias reedições. Podemos, pois, afirmar com alguma segurança que os best-sellers do nosso Romantismo [entre 1840 e 1860] foram: A Virgem da Polônia, de José Joaquim Rodrigues de Bastos; Eurico, O Presbitero, de Alexandre Herculano; A Mão do Finado, de Alfredo Possolo Hogan e Maria! Não me mates, que sou tua mãe, de Camilo Castelo Branco." (SOBREIRA, 2001, p. 3).
} 
Agulha em Palheiro e A Queda dum Anjo, quatro edições cada; e Cenas Contemporâneas, três edições (Cf. MARQUES, H., 1925, p. 190-208).

De acordo com Fernando Guedes, no catálogo, por exemplo, do Gabinete Alcobacense, de 1875, encontram-se listados "vinte e oito romances de Camilo, quatro obras de Almeida Garrett, cinco de Rebelo da Silva, outras tantas de Júlio Dinis, seis de Pinheiro Chagas e quatro de Alexandre Herculano" (1987, p. 194), o que mostra a supremacia de Camilo perante os outros escritores do período, que possuem muito menos obras à venda. $\mathrm{O}$ autor de Amor de Perdição foi também uma figura central no meio literário português oitocentista, tendo se relacionado com vários intelectuais da época - como atesta a sua vultosa correspondência com escritores como, por exemplo, António Feliciano de Castilho -, além de ter encabeçado diversas polêmicas célebres, dentre as quais se destaca a com o brasileiro Carlos de Laet, na ocasião da publicação do Cancioneiro Alegre de Poetas Portugueses e Brasileiros $^{2}$. De certa forma, sua opinião tinha grande relevância para muitos autores: como Jacinto do Prado Coelho explica, durante as décadas de 1860 e 1870 “vários jovens realistas [vinham] oferecer-lhe as suas primícias literárias” (2001, p. 332), pedindo a sua aprovação antes de enviarem os seus trabalhos para publicação - foi o caso de Antero de Quental, que acabou dedicando a Camilo o conjunto de sonetos intitulado "A Ideia”, presente em suas Odes Modernas $^{3}$.

\footnotetext{
${ }^{2}$ Propomos uma reflexão mais aprofundada sobre o Cancioneiro Alegre de Poetas Portugueses e Brasileiros no artigo "A literatura brasileira sob o olhar do escritor português oitocentista: pontes e polêmicas", a ser publicado nas Atas do $6^{\circ}$ Colóquio do PPRLB, Portugal no Brasil: pontes para o presente, realizado em abril de 2012 no Real Gabinete Português de Leitura do Rio de Janeiro, que se encontram no prelo.

${ }^{3}$ Segundo Prado Coelho, “[...] dum modo geral, não obstante determinadas incongruências próprias do seu temperamento, Camilo apreciava os autores realistas, Eça em primeiro plano, e nutria alguma benevolência pela escola nova" (2001, p. 332). De acordo com o crítico, o autor envolvia-se em polêmicas - como a provocada pelo seu opúsculo Vaidades Irritadas e Irritantes - porque, "simplesmente, quando se via ameaçado na sua popularidade, reagia" (2001, p. 332). Por outro lado, como se observa na correspondência com Castilho, Camilo envolveu-se na Questão Coimbrã, apesar da relação cordial que tinha com Antero, a pedido de seu amigo. Numa carta datada de 25 de novembro de 1865, Castilho escreve: "Permita-me [...] rogar-lhe como aquele que, por mais lido e querido de toda a gente, maiores forças tem para persuadir, faça desenganadamente causa sua desta periclitantíssima causa das letras pátrias. Empregue toda a autoridade do seu talento, e toda a sedução do seu estilo em guerrear esta já mais que proterva escola dos disparates. Vença o seu nojo de pessoa asseada, e faça com o escalpelo do ridículo a dissecção destes pustulentos para que todo o povo reconheça, pelos seus olhos, que
} 
Tendo-se em vista essas questões, depreendemos a importância que Camilo e Macedo tiveram tanto na esfera intelectual e artística, quanto no mercado editorial oitocentista português e brasileiro a partir da década de 1840, quando iniciaram as suas carreiras literárias. Faz-se necessário, contudo, situarmos esses autores no contexto mais abrangente da ascensão do romance - o que faremos a seguir -, a fim de compreendermos as intensas relações de produção e consumo entre os centros e as periferias do capitalismo, que acabaram influenciando na própria forma e conteúdo da ficção camiliana e macediana, como procuraremos mostrar ao longo deste trabalho.

Como sabemos, a ascensão do romance moderno, erigido a partir das duas grandes revoluções burguesas - a Industrial e a Francesa -, não foi um fenômeno homogêneo, e, como não poderia deixar de ser, deu-se de maneira diversa nos centros e nas periferias do capitalismo. De acordo com Franco Moretti em seu Atlas do Romance Europeu, não houve apenas um surto de ascensão do romance, mas pelo menos três: o primeiro entre 1720 e 1750 , na Grã-Bretanha, França e, um pouco mais tarde, na Alemanha; o segundo, em torno de 1820 e 1850, em “cerca de meia dúzia de países"; e um terceiro, ainda mais tarde, para os demais (2003a, p. 184-185). Segundo o crítico, a consequência da centralização da produção literária romanesca em Londres e Paris, entre 1750 e 1850, é que, "na maior parte dos países europeus, a maioria dos romances são, muito simplesmente, livros estrangeiros" (2003a, p. 197, grifo do autor). Com isso, os leitores dos países periféricos "se familiarizam com a nova forma por meio dos romances franceses e ingleses: e, também, inevitavelmente, os romances franceses e ingleses se tornam modelos a ser imitados" (2003a, p. 197, grifo do autor) ${ }^{4}$.

dentro naqueles roncadores, nem há cérebro nem coração, nem entranha alguma nobre, se não só muitos grandes bofes para urnear fígados muito ruins, e fel que faz espanto!” (1924, p. 23).

\footnotetext{
${ }^{4}$ Sabemos que os centros também não devem ser vistos de forma homogênea, uma vez que havia diferenças entre as literaturas produzidas na França, na Inglaterra e na Alemanha, países que vivenciaram seus próprios processos de ascensão do romance. Entretanto, não iremos abordar essas distinções durante a nossa análise, uma vez que não nos parece que os escritores, críticos e leitores luso-brasileiros do século XIX tivessem percepção de tais divergências.
} 
Roberto Schwarz explica que "o romance existiu no Brasil, antes de haver romancistas brasileiros. Quando apareceram, foi natural que estes seguissem os modelos, bons e ruins, que a Europa já havia estabelecido em nossos hábitos de leitura" (2000a, p. 35). Ao estudar os primórdios do romance em folhetim no Brasil, Marlyse Meyer explica que os portugueses pouco influenciaram os nossos autores. Segundo a pesquisadora, "a tão falada influência de Garrett e Herculano nos iniciadores [...] do gênero histórico no Brasil não se coaduna com as datas de publicação" (1996, p. 48). Como ela constata, O Arco de Sant'Ana, de Garrett, só fora publicado em $1845^{5}$, e os romances $O$ Bobo, Eurico, o Presbítero e $O$ Monge de Cister, de Herculano, saíram no Panorama em 1843, 1844 e 1848, respectivamente. Por outro lado, obras de autores hoje desconhecidos, como João Manuel da Silva, Justiniano José da Rocha e Joaquim Norberto, foram publicadas entre o final da década de 1820 e início da de 1840 (Cf. MEYER, 1996, p. 48).

O mercado editorial brasileiro durante o final do século XVIII e início do século XIX foi dominado, portanto, por romances franceses como As Aventuras de Telêmaco, de Fénelon, História de Gil Blas de Santilhana, de Lesage, e A História do Imperador Carlos Magno, de autor desconhecido, os mais solicitados nos pedidos de autorização à Real Mesa Censória para envio de obras ao Rio de Janeiro entre o período de 1769 e 1826, segundo a pesquisa de Márcia Abreu (Cf. ABREU, 2002, p. 132-133; p. 139-140). De acordo com Sandra Vasconcelos, romances ingleses como Viagens de Guliver, de Swift, Vida e Aventuras Admiráveis de Robinson Crusoe, de Defoe, História da Infeliz Clarissa Harlowe, de Richardson, e Tom Jones ou O Enjeitado, de Fielding, também foram muito lidos no país nesse período, sendo encontrados em avisos nos jornais (Cf. VASCONCELOS, 2002b, p. 23). São estas as obras, portanto, que influenciaram a formação do gosto do público leitor brasileiro e, por conseguinte, a formação do romance nacional.

\footnotetext{
${ }^{5}$ Lembramos que, em 1845, Garrett publicou apenas o primeiro volume desse romance; o segundo volume somente iria ser lançado em 1850.
} 
Como explica Eduardo Lourenço, “a classe dirigente do novo Brasil, do Brasil cada vez mais ‘brasileiro', mas multirracial e multicultural, não podia fazer o processo da sua própria dominação, da continuidade 'luso-colonial' que nela se perpetua” (2001, p. 139). Segundo o crítico, "a sua estratégia - consciente e inconsciente ao mesmo tempo - foi a de se ir esquecendo do seu natural passado, de deslocar a sua atenção cultural para novas fontes de cultura (França, Inglaterra [...])” (2001, p. 139, grifo do autor). De acordo com José Veríssimo, “[...] os escritores brasileiros contemporâneos de Garrett são intencionalmente nacionalistas, isto é, têm a preocupação de dar ao seu país uma literatura sua. Deles data a nossa emancipação da cultura portuguesa, e a imitação de outras literaturas, principalmente da francesa" (1977, p. 97).

Entretanto, ainda segundo Lourenço, essa tentativa de esquecimento "não os afastava [os brasileiros] assim tanto de nós [os portugueses], que, indigentes também, nos comportávamos da mesma maneira em relação à Europa [França e Inglaterra]” (2001, p. 139140, grifo do autor). A condição periférica perante os centros do capitalismo, também centros culturais e literários, não era exclusividade brasileira ou de países coloniais. Portugal, entre outros países europeus, também se encontrava à periferia do velho continente, subordinado economicamente e culturalmente às duas grandes potências, como bem apontou Boaventura de Sousa Santos ao lembrar que a nação portuguesa foi "simultaneamente o centro de um grande império colonial e a periferia da Europa" (1994, p. 59).

No primeiro volume de A Tradução em Portugal, A. A. Gonçalves Rodrigues faz um inventário das obras estrangeiras traduzidas em Portugal de 1495 a 1834. Entre os livros traduzidos do final do século XVIII até as primeiras décadas do XIX, encontramos os mesmos apontados nas pesquisas de Márcia Abreu e Sandra Vasconcelos sobre a formação do romance brasileiro. Como sabemos, muitas das obras francesas e inglesas consumidas no Brasil eram traduzidas por autores portugueses. Apesar de o inventário de Rodrigues não 
apontar o quanto esses livros estrangeiros foram lidos em Portugal, o fato de terem sido traduzidos demonstra que havia uma demanda para essas obras. Nesse sentido, podemos inferir que as mesmas obras francesas e inglesas moldaram o gosto médio do público leitor português e do brasileiro, e que, portanto, o processo de formação do romance em ambos os países se assemelhou.

De fato, a produção de romances no Brasil e em Portugal só se disseminou em meados do século XIX, após a entrada de Joaquim Manuel de Macedo e, posteriormente, de José de Alencar no mercado editorial brasileiro, e com a popularidade de Camilo Castelo Branco em Portugal, que pavimentou o caminho aberto por Garrett e Herculano. No entanto, os romances estrangeiros - sobretudo os franceses - continuavam a dominar o mercado editorial português e o brasileiro, passando a ser vistos como uma concorrência para os autores nacionais ${ }^{6}$. Nas palavras de Álvaro Manuel Machado, “daí Eça, [...] num texto célebre intitulado [...] O francesismo, dizer que 'Portugal é um país traduzido do francês em calão"” (1983, p. 11). Como podemos depreender do trecho a seguir, retirado de Uma Viagem pela Literatura Contemporânea (1856), em que Ernesto Biester comenta a obra de Rebelo da Silva, os romances franceses eram, a princípio, mais apreciados do que os escritos por autores portugueses:

\begin{abstract}
A curiosidade leva-nos a estudar de perto os rasgos críticos de Gustave Planche, as deliciosas novelas esbocetos de Charles Dickens, as delicadas fantasias de Alfredo de Musset, e os desequilíbrios arrojados de Dumas (pai) o briareu, cujos cem braços escrevem todos ao mesmo tempo; e enquanto aplaudimos uns, e nos apaixonamos pelos outros, parecem-nos pequenas, enfezadas e despiciendas as obras dos nossos escritores. (1856, p. 2).
\end{abstract}

\footnotetext{
6 "Se é verdade que o aumento da atividade editorial está relacionado com uma clara intensificação da criação de narrativas [...], ele corresponde, sobretudo, a uma abundantíssima produção de traduções da novelística francesa. 'Elle' ['um espirituoso folhetinista da época' que utilizava esse pseudônimo] [...] comenta precisamente que 'os nossos livreiros não querem ser editores, e riem-se, com certo ar de piedade, dos que se resolvem a empreender publicações, visto que não há livreiros que comprem originais' (in Revista Popular, n. ${ }^{\circ}$ 9, p. 71, maio 1849). Em geral, os editores preferiam investir em traduções de obras com êxito já comprovado no estrangeiro, e que, portanto, lhes davam garantias de obtenção de lucros, a apostar nos autores nacionais, o que obviamente implicava correr um risco financeiro maior." (SOBREIRA, 2001, p. 1-2).
} 
De acordo com Paulo Motta Oliveira, “em meados do século XIX Portugal era [...] um território ocupado pelo romance francês" (2009, p. 1). Segundo o crítico, "como pode ser apreendido a partir de A tradução em Portugal de Gonçalves Rodrigues, de 1851 a 1860 foram lançadas 9 traduções de romances de Victor Hugo, 16 de Emile Souvestre, 32 de Eugênio Sue e o espantoso total de 109 de Alexandre Dumas" (2009, p. 1). Como mostra a pesquisa de Juliana Maia de Queiroz a partir do catálogo da Livraria Laemmert, de 1868, o romance estrangeiro também era onipresente no Brasil na segunda metade do século XIX:

Dentre os autores de língua inglesa e francesa, aqueles que possuem a maior quantidade de livros traduzidos são: Chateaubriand; Xavier de Montepin; Octavio Feuillet; Fenimore Cooper; Georges Sand; Méry; Alexandre Dumas (pai e filho); Paul Féval; Victor Hugo; Paul de Kock; Voltaire; La Fontaine; Ponson du Terrail; Anne Radcliffe; Frédéric Soulié; Eugène Sue; Charles Dickens; Walter Scott. (2011, p. 60)

Refletindo a partir dos estudos de Moretti e Schwarz, Motta Oliveira mostra as semelhanças entre a formação do romance em Portugal e no Brasil, países consumidores vorazes principalmente dos folhetins franceses. Utilizando-se da expressão de Abel Barros Baptista, sobre a guerrilha discursiva que acompanhou a ascensão do gênero, o pesquisador aponta a guerrilha que existiu no "pequeno mercado português e brasileiro oitocentista [...] contra a avalanche de obras originais ou traduzidas que vinham de Paris" (2008a, p. 177). Como ele explica, "era necessário oferecer aos leitores tramas interessantes como as francesas, mas, ao mesmo tempo, suficientemente próximas das experiências cotidianas de brasileiros e portugueses para que estes, na hora decisiva da compra, preferissem um Camilo ou um Alencar, a um Eugênio Sue ou Alexandre Dumas” (2008a, p. 177-178).

Contudo, em vez de simplesmente reproduzirem essa matéria estrangeira em solo nacional, alguns escritores, através de uma aparente adesão ao modelo folhetinesco com o intuito de atender às demandas do público leitor, propunham ao mesmo tempo uma subversão 
desse mesmo modelo, produzindo, como Silviano Santiago explica, um "movimento de desvio da norma, ativo e destruidor, que transfigura os elementos feitos e imutáveis que os europeus exportavam para o Novo Mundo" (1978, p. 18). Segundo o crítico, a geografia latino-americana - e, a nosso ver, de todo país periférico - "deve ser uma geografia de assimilação e de agressividade, de aprendizagem e de reação, de falsa obediência [...]. Guardando o seu lugar na segunda fila, é no entanto preciso que assinale a sua diferença, marque a sua presença" (1978, p. 18). Em outro texto, Santiago defende que

Tanto em Portugal, quanto no Brasil, no século XIX, a riqueza e o interesse da literatura não vêm tanto de uma originalidade do modelo, do arcabouço abstrato ou dramático do romance ou do poema, mas da transgressão que se cria a partir de um novo uso do modelo pedido de empréstimo à cultura dominante. Assim, a obra de arte se organiza a partir de uma meditação silenciosa e traiçoeira por parte do artista que surpreende o original nas suas limitações, desarticula-o e rearticula-o consoante a sua visão segunda e meditada da temática apresentada em primeira mão na metrópole. (1978, p. 58 , grifo do autor).

Assim, pactuamos com a defesa do crítico, de que "é preciso começar hoje a ler os textos românticos do Novo Mundo. Nesse espaço, se o significante é o mesmo, o significado circula uma outra mensagem, uma mensagem invertida" (1978, p. 24). Tal mensagem invertida se configuraria através do discurso paródico, uma vez que, sob esse ponto de vista, nas palavras de Santiago, "o trabalho do escritor em lugar de ser comparado ao de uma tradução literal, se propõe antes como uma espécie de tradução global, de pastiche, de paródia, de digressão" (1978, p. 23). A nosso ver, tal movimento de subversão da norma também pode ser encontrado em escritores portugueses. Como afirma Maria Fernanda de Abreu, "dada a condição tardia do Romantismo português, talvez não fosse ousado dizer que uma parte importante da produção romântica portuguesa é intrínseca e, inevitavelmente, paródica" (1997, p. 408). Trata-se, por conseguinte, de uma relação dialógica das periferias com os centros, e não de cópia ou submissão. 
Concordamos, portanto, com Tânia Franco Carvalhal, que mostra a importância, para a literatura comparada, da reflexão de Julia Kristeva sobre a intertextualidade, bem como a de Gérard Genette sobre a paródia, que acabaram contribuindo para a ampliação do "binarismo a que tendiam os habituais paralelos nos estudos de fontes e influências" (2006, p. 52). Com isso, segundo Carvalhal, "o comparativista não se ocuparia a constatar que um texto resgata outro anterior, apropriando-se dele de alguma forma (passiva ou corrosivamente, prolongando-o ou destruindo-o), mas examinaria essas formas, caracterizando os procedimentos efetuados" (2006, p. 51-52). Para ela, o crítico deve ir ainda mais além e questionar "por que determinado texto (ou vários) são resgatados em dado momento por outra obra. Quais as razões que levaram o autor do texto mais recente a reler textos anteriores? Se o autor decidiu reescrevê-los, copiá-los, enfim, relançá-los no seu tempo, que novo sentido lhes atribui com esse deslocamento?” (2006, p. 52).

Nesse sentido, é importante termos em mente um descentramento de perspectiva, abandonando conceitos de valoração que coloquem a literatura produzida em países periféricos numa posição inferior à literatura produzida nos países centrais. Ao mesmo tempo, esse ponto de vista possibilita um estudo comparativo entre as literaturas brasileira e portuguesa a partir de suas semelhanças, como defende Benjamin Abdala Junior:

Esse descentramento solicita uma teoria literária descolonizada, com critérios próprios de valor. Em termos de literatura comparada, o mesmo impulso nos leva a enfatizar estudos pelos paralelos - um conceito mais amplo que o geográfico e que envolve simetrias socioculturais. Assim, os países ibéricos situam-se em paralelo equivalente ao de suas ex-colônias. Em lugar de um comparatismo da necessidade que vem da circulação norte/sul, vamos promover, pois, o comparatismo da solidariedade, buscando o que existe de próprio e de comum em nossas culturas. (2003, p. 67).

Assim, utilizando-nos das reflexões aqui introduzidas, proporemos uma leitura da ficção camiliana e macediana a partir de suas convergências, mostrando que a ascensão do 
romance se deu de maneira muito similar em Portugal e no Brasil, uma vez que ambos tinham como matriz os mesmos moldes, principalmente, do folhetim francês - e com eles dialogavam. Passaremos, então, nos próximos capítulos, a estudar a produção ficcional desses autores, analisando como se utilizaram das expectativas de leitura dos principais subgêneros do romance oitocentista, a fim de criarem as suas obras, com suas próprias características. 


\section{O romance sentimental e o riso autoirônico: paralelos entre best-sellers}

O romance sentimental, muitas vezes chamado de "passional" pela historiografia literária, é usualmente tido como sinônimo de romance romântico ${ }^{1}$, uma vez que a expressão do sentimento amoroso é o que costuma definir essa estética - um conceito que acaba limitando a compreensão da produção ficcional do período, que abrangeu diversos outros subgêneros, com características e temáticas distintas, como veremos nos capítulos seguintes. Segundo Sandra Vasconcelos, "Richardson [em Pamela] criou e Rousseau [em Júlia ou A Nova Heloísa] aperfeiçoou um subgênero [o romance sentimental], fornecendo assim as coordenadas que iriam nortear, em grande parte, a produção novelística da segunda metade do século [XVIII]" (2007, p. 99). De acordo com a pesquisadora, o sentimentalismo de Richardson "[...] fez escola e fundou o subgênero que [J. R.] Foster define como sendo, primeiramente, uma história de amor e, em segundo lugar, uma história de provações e adversidades, porque é por meio delas que o herói ou heroína sentimental pode mostrar sua verdadeira natureza" (2007, p. 101). Entretanto, como ela explica,

Transformado em moda literária, o romance sentimental substituiu o exame detido da experiência subjetiva por um sentimentalismo epidérmico que se materializava apenas em sinais exteriores, em mera imitação da verdadeira sensibilidade. A essa emoção artificial, vazia, os franceses chamaram sensiblerie, pela sua natureza patológica, inautêntica, desproporcional. (2007, p. 108, grifo da autora).

O mundo da ficção se enche, então, de incidentes e calamidades cujo único objetivo é envolver as personagens em situações aflitivas e dar oportunidade à expressão das emoções, esgotando o estoque das cenas de sofrimento. (2007, p. 110).

\footnotetext{
${ }^{1}$ É importante ressaltamos que, ao utilizarmos ao longo deste trabalho o termo "romântico", não estamos nos referindo ao grande Romantismo, que possui diversas facetas e características específicas para cada literatura nacional, mas à imagem - de certa forma estereotipada - atribuída à produção romântica, encontrada na crítica da época - que expressava a forma como grande parte do público oitocentista recebia as obras escritas no período -, que acabou sendo cristalizada pela historiografia literária do século XX.
} 
Essa concepção de que o romance sentimental, ao se tornar moda literária, teria se degenerado, tornando-se postiço e passando a exagerar no tom melodramático, já era denunciada desde o final do século XVIII, como podemos observar no prefácio a The School for Widows (1791), de Clara Reeve, traduzido por Vasconcelos:

Há entre os leitores de romance, nos últimos anos, uma mania por SENTIMENTO; tanto que os autores creem ser necessário recomendar suas obras com estas palavras - histórias sentimentais, peças sentimentais, contos sentimentais, viagens sentimentais, \&c.

Essa palavra, como muitas outras, parece ter-se degenerado de seu significado original e, sob esse frágil disfarce, deu origem a um grande número de histórias lamurientas, sentimentais, cheias de falsa emoção e falsa delicadeza, calculadas para excitar um tipo de sensibilidade mórbida que é desmaiar diante de toda aflição ideal e de toda provação fantástica; que tendem a debilitar a mente e privá-la dos recursos que a natureza pretendeu achar dentro de si própria. (Apud VASCONCELOS, 2007, p. 469-470, grifo da autora).

Neste prefácio, a escritora mostra o seu descontentamento com o tipo de literatura que estava sendo oferecido ao público, que aparentemente apreciava tais expedientes artificiais e, portanto, esperava encontrá-los nos romances sentimentais que lesse. Maurice Bardèche, ao estudar os modelos do romance sentimental que teriam influenciado a obra de Balzac - ou seja, os produzidos no século XVIII -, chegou à conclusão de que "a inveja, a faceirice, a vaidade, as diversas formas de amar introduzem, então, mais nuances entre as personagens femininas [...]. No entanto, a heroína, quaisquer que sejam os seus dons, quaisquer que sejam os traços de seu caráter, tem sempre uma fraqueza, ela é 'sensível",2. Como explica Vasconcelos, os romances pretendiam servir como guias de conduta para as leitoras: as heroínas dessas obras

\footnotetext{
${ }^{2}$ Tradução nossa do original: "La jalousie, la coquetterie, la vanité, les diverses façons d'aimer introduisent alors plus de nuances parmi les personnages féminins. [...] Toutefois, l'héroïne, quels que soient ses dons, quels que soient les traits de son caractère, a toujours une faiblesse, elle est 'sensible'." (BARDÈCHE, 1967, p. 6-7).
} 
[...] funcionaram como paradigmas de feminilidade. Desse modo, a virtude, a moderação, a inocência, o decoro, o bom-senso que se exigiam das mulheres eram também as qualidades essenciais de heroínas como Cecilia, Camilla, Belinda, etc. [...]. Tanto na vida real quanto na ficção, elas deviam ser pacientes, modestas, humildes e delicadas; não deviam almejar o conhecimento ou aspirar à vida intelectual e nem amar antes de serem amadas; uma vez casadas, deviam a seus maridos obediência e submissão. O romance sentimental [...] iria levar esse modelo a uma espécie de paroxismo, estabelecendo um tipo de paradigma que se transformou numa fórmula, mediante a sua constante repetição por grande parte dos escritores. Não há heroína dos romances populares que não sejam muito belas, delicadas ao extremo, donas de sensibilidade aguda, propensas a desmaios frequentes e lágrimas abundantes. Modelos de virtude e perfeição, eram vítimas inocentes permanentemente ameaçadas por vilões terríveis e incansáveis ou por paixões descontroladas. Se desafortunadas a ponto de não resistir à sedução, eram fadadas ao enclausuramento perpétuo num convento [...] ou à morte inescapável. (2007, p. 133).

A construção dos personagens masculinos, por sua vez, também não escapou de se tornar um clichê. Segundo Bardèche, “nunca o 'herói de romance’ foi um personagem mais ‘estereotipado' do que no início do século XIX: desenvolvido ao longo do século anterior, ele é alçado a uma espécie de perfeição. Tudo conspira a torná-lo interessante: sua reputação, sua coragem, seu senso de honra". Além disso, o crítico ressalta que "todos têm paixões violentas, e se encontram marcados por uma espécie de sinal fatal que os comprometem às provas de amor e ao desespero" "3. Uma outra faceta dos protagonistas masculinos encontrados no romance sentimental está plasmada na imagem do herói byroniano, reproduzido pelos escritores românticos - de vários países - à exaustão. De acordo com Arnold Hauser,

O herói byroniano [...] domina toda a literatura do século XIX [...]. Pois o "fora da lei", que declara guerra à sociedade e é um inimigo destemido dos grandes e poderosos mas um amigo e benfeitor dos pobres e dos fracos, já é uma figura sobejamente conhecida nesse gênero. [...] O amargo misantropo a suportar seu destino. [...] É um homem misterioso; existe um segredo no seu passado [...]. Ele é um exilado - todos o sentem, mas ninguém sabe o que está escondido através do véu do tempo, e o herói não se dispõe a erguê-lo

\footnotetext{
${ }^{3}$ Tradução nossa do trecho: “Jamais le 'héros de roman' n’a été un personnage plus 'stéréotypé' qu'au début du XIXe siècle: élaboré pendant le cours du siècle précédent, il est parvenu à une sorte de perfection. Tout conspire à le rendre intéressant: sa réputation, son courage, son sens de l'honneur [...]. Tous ont des passions violentes, et se trouvent marqués d'une sorte de signe fatal qui les promet aux épreuves de l'amour et au désespoir [...]." (BARDÈCHE, 1967, p. 6).
} 
[...]. Não se poupa a si mesmo e é implacável com os outros. Não sabe o que é perdão e não pede clemência a Deus ou aos homens. Nada lamenta e, apesar de sua vida desastrosa, não desejaria que as coisas tivessem sido diferentes do que foram, fazer algo de um modo diferente do que fez ou que algo acontecesse de maneira diferente da que aconteceu. É rude e selvagem, mas de alta estirpe [...]. (2003, p. 712-713).

Como Brito Broca afirma, os romancistas brasileiros, "na esteira dos estrangeiros, principalmente dos franceses” (1979, p. 122), construíam o herói romântico a partir de “[...] uma imagem perfeita de pureza e virtude. De pureza e virtude quase desumanas. Porque mesmo nas circunstâncias em que a fraqueza inerente a todo ser humano, justificaria uma falta, o herói romântico não claudicava uma linha sequer na sua conduta irrepreensível" (1979, p. 122). Assim, segundo o crítico, “[...] muitos desses jovens aparentemente frágeis mostravam-se, por vezes, capazes das maiores bravuras, dos atos mais intrépidos e arrojados" (1979, p. 122).

Ao comentar sobre o romance Uma Paixão de Artista, de João Manuel Pereira da Silva, publicado em 1838, Broca defende que nele "se prenunciavam [...] os cacoetes da escola" (1979, p. 181): "aí se acham pois, muito bem configurados, alguns dos elementos mais típicos do Romantismo sentimental: a paixão desvairada e sem remédio [...], e a morte como a única solução para os males do amor" (1979, p. 181). Outras obras brasileiras que costumam ser apontadas como sentimentais pela crítica são O Filho do Pescador (1843), de Teixeira e Sousa, e Cinco Minutos (1856), A Viuvinha (1857) e Lucíola (1862), de José de Alencar (Cf. ALMEIDA, S., s/d, p. 927-928). No caso dos portugueses, a historiografia literária centra-se na obra de Camilo Castelo Branco - a nosso ver, uma leitura questionável da produção do autor - e destaca, "no que respeita à narrativa passional, dois escritores [que] prepararam o terreno em que Camilo viria logo mais a notabilizar-se: D. João de Azevedo (1811-1854), autor d'O Cético (1849) e O Misantropo (1851)" e “António Pedro Lopes de Mendonça [...], autor das Memórias dum Doido (1846)” (MOISÉS, 2003, p. 126). Maria 
Isabel Rocheta, por sua vez, enumera as características do romance sentimental português por ela chamado de "narrativa passional":

Na narrativa passional, o sentir do narrador constitui o principal estímulo da narração [...]. O saber dizer, navegando no "fleuve du tendre", insistindo na dor das personagens, sacralizando o seu sentir [...], conduz ao saber ler, e na "voluptuosidade da dor" - cara a narradores, personagens e leitores da época - se consegue o patético-sentimental característico da novelística romântica [...]. A hipervalorização do afetivo, a exaltação dos sentimentos, vivendo-se o amor como único fator de engrandecimento pessoal. Em posição de protagonista encontramos muitas vezes o par amoroso que obstáculos exteriores e interiorizados [...] levam à vivência do amor paixão, [...] paixão entendida, pois, como a própria etimologia indica, como sofrimento que pode levar à loucura e à morte [...]. (1997, p. 366-367).

Leandro Thomaz de Almeida lembra que suscitar o patético era um dos objetivos do romance sentimental no século XIX, aspecto valorizado, por exemplo, pelo crítico oitocentista Antonio Francisco Dutra e Mello, no elogio que este faz a A Moreninha ${ }^{4}$. Como o pesquisador explica, “[...] ao comentar um trecho [desse romance] [...], Dutra e Mello exclama: 'que verdade, que harmonia, que graça em tão poucas palavras!' Para ele, essa cena move os afetos a ponto de dizer ele que tudo nela é "patético"' (2008, p. 28). Francisco Freire de Carvalho, no manual de retórica publicado em 1834, intitulado Lições Elementares de Eloquência Nacional, ensina como se deve fazer para produzir o patético - lições que, por serem valorizadas tanto pela crítica quanto pelo público leitor, muitos escritores procuraram seguir em suas obras ficcionais, a fim de derramar lágrimas do leitor:

Para o Orador excitar os afetos Patéticos na alma dos seus ouvintes, os mais adequados meios, de que se pode servir, reduzem-se: $1^{\circ}$. A trabalhar, quanto for possível, por se apaixonar verdadeiramente a si mesmo; pois nunca pode esperar que os seus ouvintes se condoam, por exemplo, de um mal, que ele conta sem dor alguma; nem que se indignem contra uma cousa, contra a qual observam que ele mesmo, que a conta, se não mostra intimamente indignado.

\footnotetext{
${ }^{4}$ Não concordamos com os aspectos levantados por Dutra e Mello com relação à obra macediana, os quais iremos discutir no capítulo 3.2.
} 
[...] As regras mais particulares para despertar os afetos Patéticos, podem reduzir-se às sete seguintes: $1^{\mathrm{a}}[\ldots]$ se ele quiser excitar nos seus ouvintes uma comoção duradoura, deve convencê-los das razões poderosas, que há para abraçarem a opinião proposta pelo Orador, e para defenderem com zelo o seu partido; pondo-os por este modo em estado de poderem justificar a seus próprios olhos a paixão, a que se entregam, e ficando certos de que se não têm deixado seduzir por uma ilusão vã.

[...] Regra sexta: Evitará o misturar com a parte patética do discurso cousas, que lhe sejam estranhas; fugindo, por exemplo, de interromper com Digressões, pelo menos, longas, ou de desviar por outro qualquer modo o curso da paixão, depois que ela começa a nascer [...]. Por ocasião desta mesma regra cumpre advertir ao Orador, que se abstenha de raciocinar, ou pelo menos de fazer um tecido de raciocínios abstratos, principalmente quando se ocupa de mover a vontade. (1856, p. 81-85, grifo do autor).

Em suma, para promover o arrebatamento das emoções, é necessário que o narrador se compadeça da história que conta, fazendo com o que o leitor se identifique com os personagens, convencendo-o da legitimidade de seus infortúnios. Além disso, a exaltação do sentimento nunca pode ser suplantada pela análise crítica e racional da situação.

Assim, com base nas questões que introduzimos neste capítulo, procuramos apontar as principais características do romance sentimental em voga no século XIX, consumido em Portugal e no Brasil, desenvolvido a partir do romance setecentista inglês e francês. Não queremos, é certo, afirmar que todas essas características estariam presentes em todos os romances sentimentais produzidos na época, em todos os países; no entanto, acreditamos que elas correspondam aos lugares-comuns desse subgênero, aos modelos mais típicos com os quais os autores dialogavam e às expectativas de leitura do público médio, consumidor de folhetins, que apreciava tais temáticas e procedimentos narrativos. Tendo-se isso em vista, seguiremos para a análise dos mais conhecidos romances sentimentais de Camilo e Macedo, a fim de verificarmos a forma como esses autores se apropriaram desses modelos romanescos - como veremos, não através de mera cópia, mas a partir de um diálogo crítico e, muitas vezes, autoirônico 5 .

\footnotetext{
${ }^{5}$ A discussão sobre o uso da ironia romântica como estratégia narrativa será abordada por nós na Conclusão.
} 


\subsection{Amor de Perdição, uma história de homens, feitos bárbaros, em nome de sua honra ${ }^{6}$}

Como discutimos anteriormente, Amor de Perdição: memórias de uma família, publicada em 1862, é a obra mais famosa de Camilo Castelo Branco e a mais representativa dentre os romances sentimentais que escreveu. Segundo Jacinto do Prado Coelho, por exemplo, "a novela típica de Camilo" seria "a novela passional nos moldes de Amor de Perdição" (2001, p. 202), romance que seria "uma obra-prima do gênero, aliás de estirpe europeia, com alguma coisa do sublime de Romeu e Julieta e do trágico de Manon Lescaut" (2001, p. 260). Para António José Saraiva e Óscar Lopes, por sua vez, o que interessaria na obra de Camilo seria

[...] qualquer coisa de muito importante que em dados momentos a transcende e ainda hoje comove. O amor é a face que assume, perante Camilo, como perante muitas pessoas atuais, uma ansiedade de comunhão humana total da qual apenas nos apercebemos na circunstancialidade trágica dos seus impossíveis. (1996, p. 791).

Assim, o que comumente encontramos na imensa fortuna crítica desse romance é o elogio ao sentimentalismo e à suposta centralidade do amor em sua trama. Sabemos que o seu enredo se baseia na história de amor contrariado entre Simão Botelho e Teresa de Albuquerque, cujos pais eram inimigos e contrários ao seu casamento. Estudante em Coimbra, o rapaz aloja-se em Viseu na casa do ferrador João da Cruz, a fim de aproximar-se da amada, que estava prometida a Baltasar Coutinho, seu primo. Por recusar o casamento com o primo, Teresa é enviada ao convento; já Simão acaba assassinando o seu rival e é preso, sendo

\footnotetext{
${ }^{6}$ Ressalvamos que algumas das análises presentes neste capítulo, sobre Amor de Perdição, foram exploradas de maneira mais detalhada - sob outra ótica, no entanto - em nossa Dissertação de Mestrado, intitulada Entre o Coração e o Estômago: o olhar distanciado de Camilo Castelo Branco. Nela, trabalhamos suficientemente com a crítica social e anticlerical engendrada pelo autor, questão que optamos por não abordar aqui.
} 
condenado à forca. Seu pai, corregedor, consegue mudar a sua pena para dez anos de prisão; Simão, no entanto, prefere o degredo à Índia. Mariana, filha de João da Cruz e apaixonada pelo estudante, auxilia o rapaz na prisão e decide acompanhá-lo em sua condenação ao degredo. No navio, ao saber do falecimento de Teresa no convento, Simão adoece e morre; quando o seu corpo é jogado ao mar, Mariana suicida-se, agarrando-se a ele. No bolso de seu avental é encontrado um maço com a correspondência de Simão e Teresa, que supostamente teria sido utilizada pelo autor para escrever o romance.

Apesar de aparentemente o amor ser a força motriz dos acontecimentos, cuja impossibilidade de consumação teria sido responsável pelos sofrimentos dos personagens, podemos encontrar, na leitura do romance, algumas passagens que contrariam essa perspectiva. De acordo com o que o narrador anuncia em seu prefácio, Amor de Perdição não se trata de uma história de amor, mas de ódio:

Assim eu lhe soubesse dizer o doloroso sobressalto que me causaram aquelas linhas, de propósito procuradas, e lidas com amargura e respeito e, ao mesmo tempo, ódio. Ódio, sim... A tempo verão se é perdoável o ódio, ou se antes me não fora melhor abrir mão desde já de uma história que me pode acarear enojos dos frios julgadores do coração, e das sentenças que eu aqui lavrar contra a falsa virtude de homens, feitos bárbaros, em nome de sua honra. $\left(A P^{7}\right.$, p. 384$)$.

Voltaremos a essa questão algumas páginas adiante. É interessante notarmos, por ora, que o grande amor que Simão e Teresa poderiam sentir também é, por vezes, contestado pelo narrador, que duvida de sua impetuosidade:

Os poetas cansam-nos a paciência a falarem do amor da mulher aos quinze anos, como paixão perigosa, única e inflexível. Alguns prosadores de romances dizem o mesmo. Enganam-se ambos. $\mathrm{O}$ amor dos quinze anos é uma brincadeira; é a última manifestação do amor às bonecas [...].

\footnotetext{
${ }^{7}$ Ao longo deste trabalho adotaremos a sigla $A P$ sempre que citarmos o romance Amor de Perdição, de Camilo Castelo Branco. As citações são retiradas do volume III das Obras Completas (1984).
} 
Teresa de Albuquerque devia ser, porventura, uma exceção no seu amor. (AP, p. 399, grifo nosso).

A inserção do advérbio "porventura" acaba por enfraquecer a concepção do sentimento amoroso nutrido pela heroína, o qual o narrador não parece levar muito a sério. Em outro momento, ele discute se Teresa não seria tão devota a Simão por ter sido criada longe do contato social com outros rapazes e desconhecer os prazeres de ser cortejada - e se questiona se ela, de fato, tivesse tido uma vida social mais agitada, seu amor seria tão exacerbado. Nas palavras do narrador camiliano,

Não era muito que Tadeu de Albuquerque [pai de Teresa] fosse enganado em coisas de amor e coração de mulher, cujas variantes são tantas e tão caprichosas, que eu não sei se alguma máxima pode ser-nos guia, a não ser esta: "Em cada mulher, quatro mulheres incompreensíveis, pensando alternadamente como se hão de desmentir umas às outras". Isto é o mais seguro, mas não é infalível. Aí está Teresa que parece ser única em si. Dirse-á que as três da conta, que diz a sentença, não podem coexistir com a quarta, aos quinze anos? Também o penso assim, posto que a fixidez, a constância daquele amor, funda em causa independente do coração: é porque Teresa não vai à sociedade, não tem um altar em cada noite na sala, não provou o incenso doutros galãs, nem teve ainda uma hora de comparar a imagem amada, desluzida pela ausência, com a imagem amante, amor nos olhos que a fitam, e amor nas palavras que a convencem de que há um coração para cada homem, e uma só mocidade para cada mulher. Quem me diz a mim que Teresa teria em si as quatro mulheres da máxima, se o vapor de quatro incensórios lhe estonteasse o espírito? Não é fácil, nem preciso decidir. (AP, p. 404).

Parece-nos, assim, que o sentimentalismo excessivo, apesar de estar presente no mote do romance, é por vezes questionado pelo narrador, o que mostra a sua consciência perante a artificialidade dessa temática, posta em prática para agradar ao leitor que apreciava esse tipo de narrativa. Por outro lado, apesar de ter o destino das heroínas românticas, ou seja, o convento e a morte, Teresa também se afasta dos lugares-comuns reservados às personagens femininas do romance sentimental, ingênuas e submissas. Como ilustra um comentário do narrador - já notado por críticos como, por exemplo, Prado Coelho (Cf. 2001, p. 250) -, "Não 
será aleive atribuir-lhe uma pouca de astúcia, ou hipocrisia, se quiserem: perspicácia seria mais correto dizer. Teresa adivinha que a lealdade tropeça a cada passo na estrada real da vida, e que os melhores fins se atingem por atalhos onde não cabem a franqueza e a sinceridade" (AP, p. 409).

Tal juízo do narrador é justificado pelos atos de Teresa ao longo da diegese. No início, a personagem finge amor e respeito filiais, para convencer o seu pai a não enviá-la ao convento: "Teresa respondeu, chorando, que entraria num convento, se essa era a vontade de seu pai: porém, que se não privasse ele de a ter em sua companhia, nem a privasse a ela dos seus afetos" (AP, p. 407-408). Trata-se de fingimento, uma vez que a personagem desejava na verdade a morte de Tadeu de Albuquerque: "ela esperava que seu velho pai falecesse para, senhora sua, lhe dar [a Simão], com o coração, o seu grande patrimônio" (AP, p. 400) - trecho que também revela o seu interesse pelo dinheiro do pai. Contudo, quando Tadeu a obriga a casar-se com Baltasar, Teresa prefere internar-se no convento, não aceitando a tradicional submissão feminina à vontade dos progenitores: "Estou mais livre que nunca. A liberdade do coração é tudo" ( $A P$, p. 436). E quando o seu pai procura transferi-la de convento, devido à proximidade da cadeia de Simão, ela também não cede: "Sei que tenho dezoito anos; as leis não sei quais são, nem me incomoda a minha ignorância. Se pode ser que mão violenta venha arrancar-me daqui, convença-se, meu pai, de que essa mão há de encontrar um cadáver” ( $A P$, p. 493).

Além disso, Teresa tenta até o final resistir às agruras do convento, e só adoece e vem a falecer - de tísica ao saber que Simão havia escolhido o degredo, a ficar em Portugal esperando por ela, apesar de sua insistência para que ele aceitasse a pena de dez anos de prisão: "Em dez anos terá morrido meu pai e eu serei tua esposa, e irei pedir ao rei que te perdoe, se não tiveres cumprido a sentença. Se vais ao degredo, para sempre te perdi, Simão, porque morrerás, ou não acharás memória de mim, quando voltares” ( $A P$, p. 524). Quando 
Simão justifica a sua escolha pelo degredo por não suportar a falta de liberdade - "Não me peças que aceite dez anos de prisão. Tu não sabes o que é a liberdade cativa de dez anos! Não compreendes a tortura dos meus vinte meses" $(A P$, p. 525) -, ele se esquece de que Teresa sabia sim o que era ser privada da liberdade, como o narrador faz questão de relembrar, chamando-a de "enclausurada [do convento] de Monchique" (AP, p. 524). A heroína, aqui, se mostra muito mais forte do que o herói, uma vez que ela passou mais tempo reclusa no convento do que Simão na cadeia, estando disposta a aguentar muito mais - enquanto ele, não.

Mariana, por sua vez, apesar de sofrer por amar o protagonista e não ser correspondida, também não adota uma postura passiva. É uma mulher varonil, que repele os avanços masculinos, com afirma o seu pai: “A Mariana!... aquilo é da pele de Satanás! Pergunte o Senhor, se algum dia falar com aquele fidalguinho Mendes, de Viseu, a troçada que ele levou com as rédeas da égua, só por lhe bulir na chinela, quando ela estava em cima da burra!" (AP, p. 502). Quando Simão asilou-se em sua casa e, mesmo depois, quando foi preso, a personagem o acompanhou o tempo todo, cuidando dele e sustentando-o com as suas próprias economias - dinheiro que ela lhe dava, mentindo-lhe que teria sido entregue pela sua mãe.

A filha do ferrador também se mostra muito mais forte do que o herói, que teme o degredo lamentando-se: "morre-se abrasado ao sol doentio daquele céu, morre-se de saudades da pátria, morre-se muitas vezes dos maus tratos dos governadores das galés, que têm um condenado na conta de fera" ( $A P$, p. 517). Otimista, ela decide acompanhá-lo no desterro, dispondo-se até mesmo a trabalhar para sustentá-lo: "Eu, se for por vontade do Senhor Simão, vou pôr uma lojinha [...]. Verá como eu amanho a vida. Afeita ao calor estou eu; Vossa Senhoria não está; mas não há de ter precisão, se Deus quiser, de andar ao tempo" $(A P, \mathrm{p}$. 517). Tanto otimismo justifica-se na sua esperança de que Simão se esquecesse de Teresa no 
degredo: "Não inventemos maravilhas de abnegação Era de mulher o coração de Mariana [...]. Amava, e tinha ciúmes de Teresa [...]. Sonhava com as delícias do desterro, porque voz humana alguma não iria lá gemer à cabeceira do desgraçado" $(A P, \text { p. 519) })^{8}$. Mesmo o seu suicídio foi um ato de bravura, como defende José-Augusto França: "ela reage, tenta intervir no curso dos acontecimentos, e é ela quem escolhe a morte, cuja lógica dramática e a força poética não devem esconder-nos a vontade da personagem” (1993, p. 289).

A figura de Simão, por outro lado, é construída a partir de vários lugares-comuns que caracterizam o típico herói romântico e byroniano. Admirador da Revolução Francesa "Mirabeau, Danton, Robespierre, Desmoulins, e muitos outros algozes e mártires do grande açougue, eram nomes de soada musical aos ouvidos de Simão" ( $A P$, p. 398) -, o protagonista mais parece uma cópia, transposta para a (semi)periferia do capitalismo, dos heróis romanescos franceses. O narrador, entretanto, ao caracterizar a Revolução como um "grande açougue", demonstra antipatia perante os seus ideais e ridiculariza os portugueses que a admiram, criticando, assim, o seu próprio personagem: segundo ele, “os sectários da Academia [...] exprimiam mais a paixão da novidade que as doutrinas do raciocínio" $(A P, \mathrm{p}$. 398).

Como o típico herói byroniano, Simão também é de família nobre, mas "na plebe de Viseu é que ele escolhe amigos e companheiros" ( $A P$, p. 395), tendo se envolvido numa briga para defender o seu criado, que tinha sido espancado por derrubar algumas vasilhas: “armado dum fueiro que descravou dum carro, partiu muitas cabeças, e rematou o trágico espetáculo pela farsa de quebrar todos os cântaros" ( $A P$, p. 395). O que poderia ser considerado um ato de bravura, no entanto, não é visto com bons olhos pelo narrador, que explica que Simão "emprega em pistolas o dinheiro dos livros, convive com os mais famosos perturbadores da Academia, e corre de noite as ruas insultando os habitantes e provocando-os

\footnotetext{
${ }^{8}$ Encontramos uma análise mais detida sobre essa questão no artigo "Riso e melancolia: figurações do amor em um mundo desencantado", publicado por Paulo Motta Oliveira nos Anais do III Seminário de Literaturas de Lingua Portuguesa: Portugal e África (2004).
} 
à luta com assuadas" (AP, p. 394-395). Dessa forma, o episódio dos cântaros mais parece ser uma demonstração do "gênio sanguinário" (Cf. AP, p. 394) de Simão do que uma demonstração de coragem. Além disso, em outra passagem, o narrador zomba desse episódio:

Simão Botelho levou de Viseu para Coimbra arrogantes convicções de sua valentia. Se recordava os chibantes pormenores da derrota em que pusera trinta aguadeiros, o som cavo das pancadas, a queda atordoada deste, o levantar-se daquele, ensanguentado, a bordoada que abrangia três a um tempo, a que afocinhava dois, a gritaria de todos, e o estrépito dos cântaros final; Simão deliciava-se nestas lembranças, como ainda não vi nalgum drama, em que o veterano de cem batalhas relembra os louros de cada uma, e esmorece, afinal, estafado de espantar, quando não é de estafar, os ouvintes. (AP, p. 397).

A sua "índole arrogante que lhe escaldava o sangue" (Cf. AP, p. 412) é tida como insensatez pelo narrador, que escarnece da forma violenta como Simão sempre pretende resolver os problemas: "Em recurso extremo, prometia assaltar com homens armados o mosteiro, ou incendiá-lo para se abrirem as portas. Este programa era o mais parecido com o espírito do acadêmico. Em vivo fogo ardia aquela pobre cabeça!” (AP, p. 456). Sua força e coragem são também questionadas ${ }^{9}$ no trecho em que o narrador relata, ironicamente, que o herói esconde de Teresa o medo que tinha de ser morto por Baltasar: "receando, porém, assustar Teresa e privar-se da entrevista, escreveu nova carta, em que não transluzia medo de ser atacado, nem sequer receio de marear-lhe a fama. Quis parecer a Simão Botelho que este era o digno porte de um amante corajoso" (AP, p. 418). O protagonista parece aspirar, portanto, a se tornar - ou parecer - um herói romântico.

Ao ser contrariado no seu amor, Simão entra em guerra contra a sociedade representada pelos seus pais - e transforma-se num "misantropo e intratável noutro gênero" (Cf. $A P$, p. 401), nunca chegando a perdoar a sua família nem a pedir clemência pelo seu crime, uma vez que não se arrepende de ter assassinado Baltasar. Dessa forma, o herói parece

\footnotetext{
${ }^{9}$ Já discutimos o contraste que o narrador faz entre a fraqueza de Simão e a altivez de Teresa e Mariana.
} 
ser movido não pelo amor, mas pelo ódio; como ele mesmo afirma numa carta a Teresa,

"Poderia viver com a paixão infeliz; mas este rancor sem vingança é um inferno" ( $A P$, p.

463). Segundo Esther de Lemos, "a relação de amor Teresa/Simão é sempre contrastada, e ao

fim gorada, pela relação de ódio Baltasar/Simão. [...] Nesta história de amor o ódio parece

destinado a triunfar" (2003, p. 42), como Camilo já havia anunciado em seu prefácio, citado

por nós páginas atrás. Entre os "homens, feitos bárbaros, em nome de sua honra" (Cf. AP, p.

384), não estão apenas os pais de Simão e Teresa, mas também o próprio protagonista. Nas

palavras de R. A. Lawton, Amor de Perdição "é apenas parcialmente uma novela de amor;

porque o ódio desempenha nele um papel bem maior do que o amor, e o amor de que nele se

fala não passa de um pretexto para os acontecimentos que nos são contados, não é a causa deles" ${ }^{10}$. Para o crítico,

Simão Botelho fornece, com efeito, o caso mais exemplar da união do orgulho e da violência, e seria difícil encontrar um herói de romance tão pouco simpático quanto esse jovem que poderia ser considerado um criminoso-nato, um jovem degenerado incapaz de se dominar, e cuja perda é causada pelo temperamento impulsivo e sanguinário o qual é necessário provar desde o início. ${ }^{11}$

\footnotetext{
${ }^{10}$ Tradução realizada por Sérgio Guimarães de Sousa no artigo "Crimes de amor? Tradição crítica de Amor de Perdição", publicado em 2007 na Revista Diacrítica, n. 21/3, p. 427, do original: “Amor de Perdição n'est que partiellement un roman d'amour, car la haine y joue un rôle bien plus grand que l'amour, et l'amour dont on y parle n'est que prétexte aux événements qui nous sont contés, non leur cause.” (LAWTON, 1964, p. 79).

11 Tradução nossa do original: “Simão Botelho fournit, en effet, le cas le plus exemplaire de l'union de l'orgueil et de la violence, et il serait difficile de trouver un héros de roman aussi peu sympathique que ce jeune homme qu'on a pu considérer comme un criminel-né, comme un jeune dégénéré incapable de se dominer, et dont la perte est cause par le tempérament impulsif et sanguinaire dont il faut preuve dès le debut." (LAWTON, 1964, p. 113). Essa ideia também é defendida por António Sérgio - de onde Lawton retirou o termo "criminoso nato" -, no artigo "Sobre o Amor de Perdição", publicado inicialmente em 1954, no $1^{\circ}$ número da Revista Camiliana: "Simão Botelho é um jovem degenerado, sem nenhuma capacidade de autodomínio ou mesura - um criminoso nato" (1974, p. 95). Mais recentemente, a adaptação cinematográfica de Mário Barroso, Um Amor de Perdição (2008), parte da mesma premissa. Contudo, concordamos com a ressalva que Sérgio Sousa faz à leitura desses críticos: "A minha discordância com Lawton está em que o pundonor de [...] Simão não é o mesmo de que participam [...] Tadeu de Albuquerque e o pai de Simão. Estes carregam o pundonor de casta que é o da pertença a um sistema que erige a posições cimeiras a linhagem e o patriarcado e que reprova a desordem social que avista na imoralidade chamada liberalismo. E, nas novelas de Camilo, o grande foco de tensão reside na emancipação liberal dos desígnios do coração, pois a autonomia sentimental é suscetível de manchar a continuidade de uma cadeia genealógica sobre a qual velam o país e a ordem antiga das famílias, pondo em risco a macroestrutura social.” (2007, p. 430).
} 
Por outro lado, como João Bigotte Chorão defende, "Simão não persegue o amor, mas a morte, como se esta fosse a meta apetecida. Destruir e destruir-se parece ser o escopo do herói romântico" (1993a, p. 17). O protagonista poderia ter fugido - ele mesmo se entrega à prisão -, ou aceitado os dez anos de cárcere: ele, no entanto, prefere o degredo, mesmo sabendo que com isso "precipita a morte de Teresa, arrancando-lhe o alento de última esperança de reencontro" (LOPES, Ó., 1994a, p. 45). A heroína, claramente, o culpa pela sua morte: "me domina a vontade de fazer-te sentir que eu não podia viver [...]. Quero que digas: - Está morta, e morreu quando eu lhe tirei a última esperança” (AP, p. 534).

O ideal de morte, buscado pelos românticos e, em especial, pelos personagens dos romances sentimentais, é criticado pelo narrador. Após Simão, utilizando-se dos lugarescomuns da estética, convidar Teresa para que "caminhemos ao encontro da morte... Há um segredo que só no sepulcro se sabe. [...] A felicidade é a morte, é o desfazerem-se em pó as fibras laceradas pela dor, é o esquecimento que salva das injúrias a memória dos padecentes" $(A P$, p. 525), o narrador comenta: "as palavras únicas de Teresa, em resposta àquela carta, significativa da turbação do infeliz, foram estas: '[...] Perdi-te... Bem sabes que sorte eu queria dar-te... e morro, porque não posso, nem poderei jamais resgatar-te"” ( $A P$, p. 525, grifo nosso). Ao que nos parece, Teresa estaria se referindo à impossibilidade de resgatar Simão da “turbação", ou seja, da cegueira provocada pelo ideal romântico. Neste trecho, com a leitura da carta do herói, Camilo inicia um derramamento sentimental que poderia levar ao patético; entretanto, a partir do olhar lúcido de Teresa - em contraste com a "turbação" de Simão -, temos a quebra dessa tensão dramática. Assim, concordamos com João Camilo dos Santos, que conclui que

Fica-me a impressão, ao ler Camilo, que as tragédias de amor que nos conta lhe aparecem como provocadas pela estupidez humana: pelo orgulho, pela mesquinhez, pela cegueira, pela paixão ou o ódio absurdos, pelo temperamento, pelas rivalidades sociais, por mal-entendidos de fácil resolução. Pressente-se às vezes que bastaria um pouco de bom-senso, de 
lucidez (o bom-senso e a lucidez que faltam ao Simão do Amor de Perdição) para, em vez da tragédia, se assistir a outra história. (1991, p. 62).

Com isso, percebemos que o narrador não procura promover a identificação com o herói, uma vez que não parece concordar com os seus atos - motivados, como procuramos mostrar, não pelo amor, mas pelo ódio e pelo desejo de se tornar um herói romântico -, o que impede o despertar dos afetos patéticos. Além disso, em vários momentos de agruras no romance, Camilo insere digressões e comentários jocosos, que também enfraquecem a tensão dramática. Numa dessas passagens, quando Simão é condenado à forca, o narrador expressa a opinião do povo, que esbraveja contra os privilégios da aristocracia e a exploração dos religiosos - aqui, o narrador opta por afastar-se da representação do sofrimento do herói, dessacralizando a sua imagem ao promover o riso:

- Quando vai ele a padecer?

- É bem feito! Vai pagar pelos inocentes que o pai mandou enforcar.

- Queria apanhar a morgada à força de balas!

- Não que estes fidalgos cuidam que não é mais senão matar!...

- Matasse ele um pobre, e tu verias como ele estava em casa!

- Também é verdade!

- E como ele vai de cara no ar!

- Deixa ir, que não tarda quem lha faça cair ao chão!...

- Dizem que o carrasco já vem pelo caminho.

- Já chegou de noite, e trazia dous cutelos numa coifa.

- Tu viste-o?

- Não; mas disse a minha comadre que lho dissera a vizinha do cunhado da irmã, que o carrasco está escondido numa enxovia.

- Tu hás de levar os teus pequenos a ver o padecente?

- Pudera não! Estes exemplos não se devem perder.

- Eu cá de mim já vi enforcar três, que me lembre, todos matadores.

- Por isso tu, há dois anos, não atiraste com a vida do Amaro Lampreia a casa do Diabo!...

- Assim foi; mas, se eu o não matasse, matava-me ele.

- Então de que voga o exemplo?

- Eu sei cá de que voga? O frei Anselmo dos Franciscanos é que prega aos pais que levem os filhos a verem os enforcados.

- Isso há de ser para o não esfolarem a ele, quando ele nos esfola com os peditórios. (AP, p. 481-482). 
Como afirma Chorão, "Camilo tem esse segredo de, nos lances mais dramáticos, introduzir uma situação ou observação caricatural, uma digressão inesperada no contexto, que servem a atenuar a tensão, a dar ânimo ao leitor, quando menos espera ser sacudido por frouxos de riso" (1990, p. 44). Segundo António Cabral, em Amor de Perdição há vários "exemplos de interrupção lúcida e lúdica do clima patológico crescente" (1993, p. 59). Para ele, “a pausa não tem apenas função relaxante: proporciona também as condições necessárias a uma observação objetiva, desafetada. É o criador a abandonar de certa maneira a sua criatura" $(1993, \text { p. 59-60) })^{12}$.

Da mesma forma, o capítulo XVI também serve como uma quebra da tensão dramática em meio ao sofrimento de Simão, preso, e Teresa convalescente. O capítulo conta a história do irmão do protagonista, Manuel Botelho, que se amancebou com uma açoriana casada com um estudante de medicina. Após a intervenção de seu pai - pois Manuel estava sendo perseguido por desertar da Cavalaria -, os amantes se separam e continuam as suas vidas sem grandes desgostos: Manuel, “obtido o perdão pela preponderância do corregedor do crime, mudou de regimento para Lisboa, e aí permaneceu até que, falecido seu pai, pediu a baixa e voltou à província" ( $A P$, p. 510$)$; a açoriana "partiu para Lisboa [...], e dali para a sua terra, e para o abrigo de sua mãe, que a julgara morta, e lhe deu anos de vida, se não ditosa, sossegada e desiludida de quimeras" ( $A P$, p. 509-510). O marido traído, por sua vez, "não morreu, nem sequer desmedrou ou levou $R$ significativo de preocupação do ânimo" $(A P, \mathrm{p}$. 509). Nas palavras do narrador, “como tinha já vasta instrução em Patologia, poupou-se à morte da vergonha, que é uma morte inventada pelo visconde de Almeida Garrett no Frei Luís de Sousa, e à morte da paixão, que é outra morte inventada pelos namorados nas cartas despeitosas" (AP, p. 508).

\footnotetext{
${ }^{12}$ António Cabral, em seu artigo "A técnica da distanciação em Camilo", publicado em Estudos Camilianos: Camilo Castelo Branco - jornalismo e literatura no século XIX, faz uma interessante comparação entre os procedimentos narrativos utilizados por Camilo e o efeito de distanciamento do teatro épico de Bertolt Brecht, questão que tratamos com maior profundidade em nossa Dissertação de Mestrado.
} 
Nesta passagem, o narrador desvela a artificialidade da literatura consumida na época, exemplificada aqui por Garrett - que em Frei Luís de Sousa apresentaria os lugarescomuns da morte romântica - e reproduzida pelo enredo central do próprio romance, que é justamente contado a partir das cartas do casal principal, que morre por causa de sua paixão. De acordo com Óscar Lopes, temos nesse capítulo "um remoque ao visconde de Almeida Garrett, a propósito de uma ridicularização de certas mortes românticas melodramáticas que, com pequenos retoques, bem se aplicariam ao próprio Amor de Perdição" (2007, p. 79). Segundo Maria Luíza Ritzel Remédios, nessa obra "Camilo evoca o romance folhetim e, ironicamente, procura desacreditá-lo, através da inversão irônica e da repetição com distanciamento crítico. Camilo, então, apesar de ser catalogado como grande autor de folhetim, o que faz nessa novela é dessacralizar o gênero" (1991, p. 802). Nas palavras de Rocha Júnior,

[...] Camilo dedicou-se a fazer chorar as leitoras. Viu que a moda literária era essa ou viu pelo menos que era essa literatura a que o público comprava. E ele escrevia para vender. Mas nos prefácios dos seus livros [e, a nosso ver, nas digressões e nos comentários do narrador], precisamente dos mais patéticos, farta-se de rir do jeito que Deus lhe deu para espremer glândulas lacrimais. (1951, p. 82)

Assim, num processo de autoironia, o autor mostra a consciência que tinha de que a história de Simão e Teresa, repleta de um sentimentalismo exacerbado, era postiça e feita para agradar ao gosto do público. Dessa forma, percebemos que, apesar de fornecer o que o seu leitor queria - um romance sentimental, cujo relato de um amor contrariado, protagonizado por um herói byroniano, termina de forma trágica -, Camilo também se desvia de certos lugares-comuns da estética. Em especial na construção de suas personagens femininas, fortes e determinadas, distantes da cristalizada imagem passiva de mulher romântica, e na análise crítica da artificialidade dos ideais do herói romântico, denunciando os 
seus motores. Ao retratar o herói de forma mais negativa do que positiva, não se condoendo com os seus infortúnios, o narrador camiliano acaba impedindo a identificação com o seu personagem e a fruição da tensão dramática. Ao contrário de "debilitar a mente", como Clara Reeve (Apud VASCONCELOS, 2007, p. 470) temia que pudesse acontecer na leitura dos romances com excesso de sentimentalismo, Amor de Perdição promove a reflexão, tanto dos comportamentos sociais, quanto da criação literária, em especial, do processo de escrita do próprio subgênero romance sentimental. 


\subsection{A Moreninha e o bichinho que obriga a fazer quanta parvoíce há neste mundo}

Em nosso primeiro capítulo, mostramos o prestígio que a publicação de $A$ Moreninha, em 1844, desfrutou não apenas na época, como nas décadas seguintes, sendo ainda hoje apontada como o marco inicial do romantismo no Brasil, como afirma José Aderaldo Castello: “[...] registra-se o grande sucesso de A Moreninha (1844), de Joaquim Manuel de Macedo, aclamada justamente a primeira realização romântica de acentuado conteúdo e preocupações brasileiros” (1999, p. 223). Entretanto, como já explicamos, o romance tem recebido pouca atenção da crítica mais especializada, que, de uma maneira geral, não costuma atribuir-lhe grande valor literário, associando-o a um sentimentalismo de imitação, alienado e alienante. Segundo, por exemplo, Alfredo Bosi, a obra segue as "receitas" do "novelesco" francês e inglês em solo brasileiro, reproduzidas depois em seus demais romances: "em todos eles o gosto do puro romanesco é importado (Scott, Dumas, Sue...), mas são nossos os ambientes, as cenas, os costumes, os tipos, em suma, o documento" (1975, p. 144, grifo do autor).

A Moreninha trata da história de Augusto, estudante de medicina no Rio de Janeiro, que é convidado por Filipe, juntamente com os seus amigos Leopoldo e Fabrício, a passarem o dia de Sant'Ana na casa de sua avó, D. Ana, na ilha de... ${ }^{13}$. Nela, Augusto, tido como um inconstante galanteador, conhece a irmã de Filipe, Carolina - a Moreninha -, e se apaixona por ela. O estudante passa, assim, a retornar várias vezes à ilha para encontrar a moça, até que o seu pai decide prendê-lo em casa, o que o deixa doente. Augusto só se cura e Carolina só recupera a alegria quando o pai do rapaz e a D. Ana aprovam o seu casamento. Ao final da diegese, dá-se o grande reconhecimento: ambos já se conheciam desde crianças,

\footnotetext{
${ }^{13}$ Macedo não nomeia a sua localização, referindo-se à ilha sempre com reticências. Posteriormente, a crítica reconheceu se tratar da Ilha de Paquetá.
} 
quando se encontraram por algumas horas e trocaram promessas de se casarem no futuro. Além disso, é revelado também o pseudoautor da obra, narrada em terceira pessoa: tratar-se-ia do próprio Augusto, que perdera a aposta que fizera com os amigos no início da história - de que, se ele amasse a uma só mulher durante quinze dias ou mais, ele teria de escrever um romance.

Logo no prefácio, Macedo avisa que seu romance não foi escrito por nenhum motivo grandioso, usualmente apregoado pelos escritores românticos: "não foi ele movido por nenhuma dessas três poderosas inspirações que tantas vezes soem amparar as penas dos autores: glória, amor e interesse" $\left(M^{14}\right.$, p. 11). Chama-nos a atenção o fato de o amor, temática que define o romance sentimental, não ser apontado como razão para a escrita da obra: “A respeito do amor não falemos, pois se me estivesse o buliçoso a fazer cócegas no coração, bem sabia eu que mais proveitoso me seria gastar meia dúzia de semanas aprendendo numa sala de dança, do que velar trinta noites garatujando o que por aí vai” $(M$, p. 11). Com isso, podemos inferir que o apaixonado Augusto - pseudoautor da história, que tenderia a ser relacionado ao próprio Macedo, uma vez que este acabara de se formar em medicina - não é de fato o escritor de A Moreninha; dessa forma, percebemos que, além de essa relação se tratar evidentemente de um expediente retórico, não se pode adotar diretamente o ponto de vista do personagem como sendo o ponto de vista defendido pela obra, o que procuraremos demonstrar páginas adiante. Ainda no prefácio, o autor afirma que sua obra é produto da falta do que fazer, negando, assim, a função social e educativa da arte:

Este pequeno romance deve sua existência somente aos dias de desenfado e folga que passei no belo Itaboraí, durante as férias do ano passado. Longe do bulício da corte e quase em ócio, a minha imaginação assentou lá consigo que bom ensejo era esse de fazer travessuras, e em resultado delas saiu $-A$ Moreninha. (M, p. 11).

\footnotetext{
${ }^{14}$ Ao longo deste trabalho adotaremos a sigla $M$ sempre que citarmos o romance $A$ Moreninha, de Joaquim Manuel de Macedo. As citações são retiradas da 25ª edição publicada pela Editora Ática (1994).
} 
Nesse sentido, podemos questionar se o romance de Macedo teria sido mesmo elaborado com vistas a ser um guia de conduta, tal como o esperado num típico romance sentimental. A Moreninha, apesar de virtuosa, não parece ser um paradigma de feminilidade que seria aprovado pelos pais da época: como afirma Valéria Augusti, "caso resolvêssemos ler as travessuras de Carolina à luz das prescrições de um livro de conduta, consideraríamos que o personagem estaria longe de apresentar um comportamento exemplar" (1998, p. 123). A imagem inicial que Augusto dela faz não é positiva:

Há cinco minutos que Augusto entrou e em tão curto espaço já ela [Carolina] sentou-se em diferentes cadeiras, desfolhou um lindo pendão de rosas, derramou no chapéu de Leopoldo mais de duas onças de água-de-colônia de um vidro que estava sobre um dos aparadores, fez chorar uma criança, deu um beliscão em Filipe, e Augusto a surpreendeu fazendo-lhe caretas: travessa, inconsequente e às vezes engraçada; viva, curiosa e em algumas ocasiões impertinente. $\mathrm{O}$ nosso estudante não pode dizer com precisão nem o que ela é, nem o que não é: acha-a estouvada, caprichosa e mesmo feia. ( $M$, p. 29).

Neste trecho, o narrador define Carolina como uma menina hiperativa, travessa, impertinente e, até mesmo, feia, o que a distancia em muito das características esperadas nas heroínas dos romances sentimentais, que deveriam exalar beleza, paciência, moderação, decoro e seriedade. Enquanto suas primas, faceiras e vaidosas, divertem-se com os galanteios dos amigos de Filipe, Carolina os repele, ridicularizando-os. De fato, a personagem não parece estar à procura de um marido, como as moças da época; segundo o narrador afirma, acerca de um passeio, ela "havia rejeitado dez braços. Queria passear só. Um braço era uma prisão e a engraçada Moreninha gosta sobretudo da liberdade. [...] Viva, com os olhos brilhantes; ágil, com seu pezinho sempre pronto para a carreira" ( $M$, p. 46). Além disso, Carolina se compraz em humilhar as suas primas namoradeiras; numa das passagens em que Quinquina finge não entender os elogios de Augusto, com o intuito de fazer com que o rapaz os repita, a Moreninha os interrompe, desvelando as estratégias do galanteio: 
- Ah!... exclamou [...] d. Carolina, eu creio que d. Quinquina terá finalmente compreendido o que o sr. Augusto tanto se empenha em lhe explicar.

- Minha prima, atreveu-se a dizer a ingênua, modesta, medrosa e muito sonsa d. Quinquina; minha prima, você o teria compreendido no primeiro instante, não é assim?...

- Certamente, respondeu a mocinha, sem perturbar-se; o sr. Augusto, além de falar com habilidade e fogo, pôs em ação três sentidos; o que poderia também suceder, era que, como algumas costumam fazer, eu fingisse não compreendê-lo logo, para dar lugar a mais vivas finezas, até que ele de fatigado, dissesse tudo, sem figuras e flores de eloquência... Ora, isso quase que aconteceu, porque os olhos, os ouvidos e o nariz do sr. Augusto hão de estar certamente cansados de tão excessivo trabalho!...

- Minha senhora!...

- Por desdita dele não houve ocasião de pôr em campo um outro sentido; o gosto ficou em inação, bem contra a sua vontade, não é assim, sr. Augusto?...

- Minha prima, todos olham para nós...

- A respeito do tato, não direi palavra, continuou a terrível Moreninha; porque se as mãos do sr. Augusto conservaram-se em justa posição, quem sabe os transes por que passariam os pés de minha prima?... Os srs. estão tão juntinhos, que com facilidade e sem risco se podem tocar por baixo da mesa. - Menina! Exclamou a sra. d. Ana, com acento de repreensão.

- Minha senhora, consinta que ela continue a gracejar, disse Augusto, meio aturdido. Além de me dar a honra de tomar-me por objeto de seus gracejos, dá-me também o prazer de apreciar e admirar seu espírito e agudeza. ( $M, \mathrm{p}$. 40).

São seus "espírito e agudeza" que irão conquistar o protagonista. Numa passagem

anterior, Carolina surpreende a sua prima Clementina - que estava falando mal de todas as outras moças para Augusto -, prestes a falar dela. E, como sempre, devolve a injúria não proferida, humilhando Clementina com ironia:

- [...] Preciso é que os ouvidos estejam bem abertos e a atenção bem apurada, quando se está defronte de uma moça como d. Clementina, que sempre tem coisas tão engraçadas e tão inocentes para dizer!... Oh! minha camarada, juro-lhe que ninguém lhe iguala na habilidade de compor um mapa.

- Mas... d. Carolina... você deu o cavaco?...

- Oh! não, não... continuou a menina, com picante ironia; porém é fato que nenhuma de nós gosta de ser ofuscada com o esplendor de outra. Já basta de brilhar, d. Clementina; o sr. Augusto deve estar tão enfeitiçado com o seu espírito e talento, que decerto não poderá toda esta tarde e noite olhar para nós outras, sem compaixão ou desgosto; portanto, já basta... se não por si, ao menos por nós.

A cronista fez-se cor de nácar e a sua adversária, imitando-a na malícia do sorriso e no acento gracejador, prosseguiu ainda: 
- Mas ninguém conclua daqui que, por ofuscada, perco o amor que tinha ao astro que me ofuscou. Bela rosa do jardim! Teus espinhos feriram a borboleta, mas nem por isso deixarás de ser beijada por ela!... [...]

- Oh! disse Augusto consigo mesmo: a tal menina travessa não é tola como me pareceu ainda há pouco. E desde então começou o nosso estudante a demorar seus olhares naquele rosto que, com tanta injustiça, tachara de irregular e feio. [...] Espichou-se tão completamente, que agora mesmo já estava pensando com os seus botões: ela não será bonita!... porém feia?... Isso é demais! ( $M$, p. 38).

Como podemos depreender das passagens citadas, Carolina se expressa de forma desenvolta, revelando a sua perspicácia, fruto de sua inteligência e da cultura adquirida na leitura de escritoras feministas ${ }^{15}$ - o que provavelmente embasava o seu comportamento considerado atrevido pelos padrões da sociedade patriarcal oitocentista. Segundo conta Leopoldo, em sua perspectiva machista, que se ri dos direitos almejados pelas mulheres,

- [...] a bela senhora é filósofa!... faze ideia! Já leu Mary de Wollstonecraft e, como esta defende o direito das mulheres, agastou-se comigo, porque lhe pedi uma comenda para quando fosse ministra de Estado, e a patente de cirurgião do exército, no caso de chegar a ser general; mas, enfim, fez as pazes, pois lhe prometi que, apenas me formasse, trabalharia para encartarme na Assembleia Provincial e lá, em lugar das maçadas de pontes, estradas e canais, promoveria a discussão de uma mensagem ao Governo Geral, em prol dos tais direitos das mulheres [...]. (M, p. 69).

\footnotetext{
15 Tânia Serra lembra que "em 1832, Nísia Floresta publica uma tradução do Direito das mulheres e injustiças dos homens, de Mary Wollstonecraft, célebre feminista inglesa e autora de quem a Moreninha confessa muito gostar. A posição da mulher na nova sociedade burguesa será tema predileto dos românticos caboclos [...]. Essa nova mulher é alfabetizada, procura ocupar uma posição mais participante na vida cultural e, sobretudo, lê os jovens romancistas românticos" (2004, p. 28). Como explica Sandra Vasconcelos, "o culto da feminilidade, forjado com base em um ponto de vista masculino, foi assumido por romancistas de ambos os sexos, com algumas exceções importantes, pois a mesma cultura que o produziu também foi capaz de fazer sua crítica. A consciência feminista desenvolveu-se lenta e gradualmente. Mesmo assim, quando o fez, foi com frequência inibida pelas visões prevalecentes com respeito à posição e à natureza da mulher. Houve algumas romancistas, entretanto, que conseguiram construir uma imagem alternativa da mulher. Sem de fato desafiar a hierarquia social ou a estrutura política, muitas delas criaram heroínas que não eram vítimas inocentes tentando defender-se num mundo infestado de predadores masculinos, mas sim mulheres inteligentes, fortes e desembaraçadas [...]. Desafiando convenções predominantes, suas vozes se levantaram para protestar contra a subordinação feminina, contra os horizontes estreitos e a falta de oportunidades" (2007, p. 137-138). A nosso ver, há escritores - tais como Macedo e Camilo - que também davam voz às aspirações femininas, condenando o seu papel secundário na sociedade, criando personagens que em muito se distanciavam da imagem da mulher ingênua e submissa.
} 
A Moreninha nunca é submissa aos homens; pelo contrário, ela impõe a sua vontade sobre Augusto, dando-lhe ordens quando ele se dispõe a realizar tarefas tipicamente femininas, apenas para agradá-la. Primeiramente, o rapaz obedece ao horário que ela estabelece para as aulas de bordado, interrompendo seus folguedos com Filipe:

- O senhor não ouviu tocar a campainha?

- Então isso era comigo?

- Sim, senhor, são horas da lição, e espero que para outra vez não me seja preciso chamá-lo.

- Aceito a admoestação, minha bela mestra, mas rogo-lhe o obséquio de consentir que termine esta partida [...].

- Não tenho a dizer-lhes o que quero, nem o que não quero; são horas da lição, vamos.

- É preciso obedecer, concluiu Augusto levantando-se [...].

Filipe apareceu na sala, pronto para ir caçar, e convidou o seu amigo para com ele partilhar do mesmo prazer [...].

- Minha bela mestra não dá licença.

- Tome cuidado do modo de pegar nessa agulha!... gritou ela, com mau modo, e sem se importar com Filipe. (M, p. 116-117).

Depois, Carolina o faz brincar com suas bonecas: "Augusto já sabe de cor e salteado todos os nomes dos membros daquela família [...], acalenta as bonecas pequenas [...], examina o guarda-roupa, batiza, casa, em uma palavra, dobra-se aos prazeres de sua bela mestra, como uma varinha ao vento" ( $M$, p. 122). O narrador, contudo, interrompe essa cena, de demonstração singela de amor romântico, rindo-se da situação; ele não vê no amor que embasa os atos do protagonista motivo de exaltação, mas de ridicularização:

Ora, o tal bichinho chamado amor é capaz de amoldar seus escolhidos a todas as circunstâncias e de obrigá-los a fazer quanta parvoíce há neste mundo. O amor faz o velho criança, o sábio doido, o rei humilde cativo; faz mesmo às vezes, com que o feio pareça bonito e o grão de areia um gigante [...]. O amor foi inventor das cabeleiras, dos dentes postiços que... mas, alto lá! que isto é bulir com muita gente; enfim, o amor está fazendo um estudante do quinto ano de medicina passar um dia inteiro brincando com bonecas. $(M$, p. 122$)$. 
O amor faz com que Augusto mude sua opinião com relação à beleza de Carolina, ainda que relute em admitir que esteja apaixonado:

- Ora viva! quero divertir-me... digo-te que a acho feia; não é lá essas coisas; parece ter mau gênio. Realmente notei-lhe muitos defeitos... sim... mas, às vezes... Olha, Leopoldo, quando ela fala ou mesmo quando está calada, ainda melhor; quando ela dança, ou mesmo quando está sentada... ah! ela, rindo-se... e até mesmo séria... quando ela canta ou toca ou brinca ou corre, com os cabelos à negligé, ou divididos em belas tranças; quando... Para que dizer mais? Sempre, Leopoldo, sempre ela é bela, formosa, encantadora, angélica! ( $M$, p. 109, grifo do autor).

Dessa forma, ao se apaixonar pela Moreninha, Augusto deixa de ser um Don Juan, "volúvel, inconstante e incapaz de amar três dias um mesmo objeto" ( $M$, p. 17). Contudo, como um exemplar do herói byroniano, o protagonista escondia um segredo do seu passado, que justificava a sua falta de comprometimento com as mulheres. Ele só conta a história de sua vida para a avó de Carolina, D. Ana, em local afastado, crendo não estar sendo ouvido por mais ninguém - a Moreninha, entretanto, ouve a conversa escondida. Sendo narrados por Augusto - e não pelo narrador macediano -, esses capítulos são repletos de um sentimentalismo derramado, combinando, assim, com o caráter do próprio personagemnarrador dessa passagem, definido sempre pelos seus amigos com o adjetivo "romântico" (Cf. $M$, p. 13; 16-17).

O rapaz relata que na infância havia conhecido na praia uma menina, pela qual se apaixonara, e com a qual tinha feito a promessa de se casar quando fosse maior, enlace abençoado por um pobre moribundo que recebera suas esmolas - passagem que torna a história ainda mais sentimentalista, além de ressaltar o caráter generoso dos protagonistas. Com o fim do dia, eles se separam e não mais voltariam a se encontrar. Augusto conta que passara anos pensando na menina, até que resolvera conhecer outras mulheres. Entretanto, como o típico herói romântico, o protagonista acabou passando por várias desilusões 
amorosas: "Não sei [...] que teve o amor comigo, para entender que todas as moças deviam rir-se de mim e zombar de meus afetos!" ( $M$, p. 56). Com isso, Augusto volta-se à sua imagem ideal de mulher, representada pela menina que conhecera na infância: “eu conservo a lembrança mais terna e constante de minha mulher: ela é o amor de meu coração, enquanto todas as outras são divertimentos dos meus olhos e o passatempo de minha vida" $(M$, p. 61).

Ao ouvir, escondida, a história que Augusto conta à sua avó, Carolina procura conquistá-lo, a fim de fazê-lo se apaixonar por ela - mulher real -, e se esquecer da imagem ideal da menina por quem se enamorou na infância - ela mesma, quando criança. Manipulando habilmente as situações, a Moreninha só revela a sua identidade no final do romance, depois que ele declara gostar mais dela do que da menina - estando, assim, finalmente liberto do ideal romântico. Contudo, como explica Maria Cecília Boechat, acerca do reconhecimento no desfecho do romance, que poderia suscitar lágrimas nos leitores,

\footnotetext{
Enquanto eles sofrem, porém, a narrativa mantém o distanciamento no tratamento da cena. "A cena estava tornando-se patética", anota o narrador, fazendo com que também o leitor se dê conta do excesso sentimentalista e perceba o ridículo da cena.

Esta notação, por si só explícita e eficaz, sendo feita exatamente no clímax do romance, momento máximo do conflito e, ao mesmo tempo, de sua dissolução, impede, ainda, uma leitura mais séria [...] do tema desenvolvido pelo romance. (2005, p. 127).
}

O narrador macediano, por sua vez, em várias passagens ridiculariza Augusto, zombando do seu comportamento de herói romanesco: como acusa Fabrício, "Apesar de todo o seu romantismo ou, talvez, principalmente por causa dele, não vês o que se passa a duas polegadas do nariz" ( $M$, p. 34). No trecho em que o rapaz narra as suas desventuras amorosas à $\mathrm{D}$. Ana, o narrador comenta, desdenhando de seu personagem e impedindo a identificação do leitor com seus infortúnios: "Finalmente, o bom estudante que, quando lhe dava para falar, era mais difuso que alguns de nossos deputados novos na discussão do artigo $1^{\circ}$ dos 
orçamentos, julgou dever fazer pausa de suspensão" ( $M$, p. 61). O protagonista também é rebaixado em diversas passagens da narrativa, a começar pelo início, em que é descrito "em ceroulas, com as fraldas à mostra, estirado em um canapé” $(M$, p. 13). Numa passagem cômica, Augusto entra no gabinete das moças para trocar de roupa, e é obrigado a esconder-se às pressas embaixo de uma cama:

[...] Augusto, com sua roupa embaixo do braço, coberto de teias de aranha e suores frios, comprimia a respiração e conservava-se mudo e quedo, medroso de que o mais pequeno ruído o pudesse descobrir [...]. A posição do estudante era penosa, certamente; por último, saltou-lhe uma pulga à ponta do nariz, e por mais que o infeliz a soprasse, a teimosa continuou a chuchálo com a mais descarada impunidade. ( $M$, p. 73$)$.

Em outro trecho, Augusto se vê tão absorto pela leitura de uma carta que se esquece de assoar-se: "só depois de devorar o convite sem assinatura, foi que lembrou-se que ainda não se havia assoado e que o pingo estava cai não cai na ponta do nariz" $(M$, p. 98). A cena em que o herói sonha com a sua amada é, por sua vez, alvo de riso do narrador, que flagra o momento em que os estudantes dormem: "e como roncam!... Mas que faz o nosso Augusto? Ri-se, murmura frases imperceptíveis, suspira...” ( $M$, p. 88). Em seguida, o narrador passa a descrever o sonho de Augusto, que estaria roubando um beijo de sua amada:

[...] finalmente, não podendo mais resistir aos seus férvidos beijos, assentara de, quando se aproximasse o belo rosto, ir de um salto colher o voluptuoso beijo naquela boquinha de botão de rosa; que o rosto chegou à distância de meio palmo e... (aqui parou o sonho e principiou a realidade) e ele deu um salto mas, em lugar de pregar um beijo nos lábios de d. Carolina, foi com toda a força e estouvamento bater com os beiços e nariz contra a testa de Fabrício; depois, como se o colega tivesse culpa de tal infelicidade, deu-lhe dois empurrões [...] $(M$, p. 89).

Dessa forma, o narrador insere um anticlímax que quebra a expectativa do leitor, que esperaria um momento de ternura. O estar apaixonado, aliás, acaba sendo visto por vezes 
como um ato ridículo Em outra passagem, o narrador afirma que "todos sabem que os amantes têm um prazer indizível em matraquear os ouvidos dos que os atendem com uma história muito comprida e mil vezes repetida que, reduzindo-se à expressão mais simples, ficaria em zero ou, quando muito, nos seguintes termos: 'eu olhei e ela olhou'” ( $M$, p. 112). Assim, o discurso romântico é rebaixado, tal como no trecho em que Leopoldo, após Augusto desabafar a angústia do amor que sente, debocha do amigo, quebrando a tensão dramática: "Modera-te, Augusto; acalma-te; não é graça; olha que estás vermelho como um pimentão" (M, p. 109).

Como não poderia deixar de acontecer num romance sentimental, há também a presença da adversidade, que funcionaria como uma provação para os personagens, reproduzindo, então, os lugares-comuns do amor contrariado, a fim de atender às expectativas do leitor. O pai de Augusto, entretanto, se coloca contra a relação amorosa do filho por um motivo extremamente prosaico: apenas estava preocupado com o fato de o estudante estar faltando em demasia às aulas na faculdade - para visitar Carolina -, e quis discipliná-lo, trancando-o em casa. Com isso, o rapaz reage de forma violenta, acabando por cair prostrado e doente. A Moreninha, por sua vez, é tomada pela melancolia, perdendo a sua alegria costumeira.

O narrador, contudo, não se compadece com os personagens; pelo contrário, desdenha de seu sofrimento, impedindo o despertar dos afetos patéticos: “Os nossos amantes acabavam de chegar ao sentimental, e com seu sentimentalismo estavam azedando a vida dos que lhes queriam bem. Os namorados são semelhantes às crianças: primeiro divertem-nos com suas momices, depois incomodam-nos choramingando" ( $M$, p. 127). Aqui, o amor é definido de forma ainda mais rebaixada, sendo comparado a uma criança mimada: “[...] amor é um menino doidinho e malcriado que, quando alguém intenta refreá-lo, chora, escarapela, 
esperneia, escabuja, morde, belisca e incomoda mais que solto e livre" ( $M$, p. 125). De acordo com Boechat,

\begin{abstract}
A partir do capítulo XXII, começam os sofrimentos dos protagonistas. Nada, entretanto, de grandes dramas: por um lado, o desvelo do pai do rapaz foge inteiramente aos modelos dos obstáculos - sociais ou existenciais - da literatura romântica; por outro, o narrador mantém distância do "drama" vivido pelos personagens. (2005, p. 126).
\end{abstract}

Dessa forma, parece-nos que o narrador macediano reproduz as convenções do romance sentimental, com o intuito de desacreditá-las e desvelar a sua artificialidade. Já no início do romance, por exemplo, encontramos a crítica aos ideais românticos, através do relato de Fabrício, que se queixa da impossibilidade de aplicar os seus preceitos na vida real. Ele conta a sua tentativa de "entabular um namoro romântico" no teatro: "Consultei com meus botões como devia principiar, concluí que para portar-me romanticamente, deveria namorar alguma moça que estivesse na quarta ordem. [...] Não sei se é bonita ou feia, mas que importa? Um romântico não cura dessas futilidades" ( $M$, p. 22). O discurso romanesco é, assim, parodiado: "passei junto do camarote de minhas atenções: era o nº 3 (número simbólico, cabalístico e fatal! repara que em tudo segui o Romantismo)” ( $M$, p. 23). Quando consegue finalmente iniciar o namoro com a moça, o personagem depara-se com a realidade e reclama dos problemas que não são descritos nos romances sentimentais:

[...] apesar de minhas economias, ando sempre com as algibeiras a tocar matinas $[\ldots]$.

Para compreenderes bem o quanto sofro, aqui te escrevo algumas das principais exigências da minha amada romântica.

$1^{\circ}$. Devo passar por defronte de sua casa duas vezes de manhã e duas à tarde. Aqui, vês bem, principia a minha vergonha, pois não há pela vizinhança gordurento caixeirinho que se não ria nas minhas barbas quatro vezes por dia.

$2^{\circ}$. Devo escrever-lhe, pelo menos, quatro cartas por semana, em papel bordado, de custo de 400 réis a folha. Ora, isto é detestável, porque eu não sei onde vá buscar mais cruzados para comprar papel, nem mais asneiras para lhe escrever. 
$3^{\circ}$. Devo tratá-la por "minha linda prima" e ela a mim por "querido primo". Daqui concluo que a sra. d. Joana leu o Faublas. Boa recomendação!...

$4^{\circ}$. Devo ir ao teatro sempre que ela for, o que sucede quatro vezes no mês; o mesmo a respeito de bailes. Esta despesa arrasa-me a mesada terrivelmente.

[...] Malditos românticos, que têm crismado tudo e trocado em seu crismar os nomes que melhor exprimem suas ideias!... O que outrora se chamava, em bom português, moça feia, os reformadores dizem: menina simpática!... O que em uma moça era antigamente desenxabimento, hoje é ao contrário: sublime languidez!... Já não há mais meninas importunas e vaidosas. As que forem, chamam-se agora espirituosas! [...].

$\mathrm{E}$ eu, apesar dos tratos que dou à minha imaginação, não posso deixar de convencer-me que a minha linda prima é (aqui para nós) amarela e feia como uma convalescente de febres perniciosas. ( $M$, p. 25-26).

Com isso, através do diálogo crítico que Macedo faz com os modelos do romance sentimental, é possível depreendermos a consciência que o autor tinha de seu caráter postiço, não se tratando de mera imitação. De acordo com Wilson Martins, "uma constante na sua obra, desde A Moreninha, é justamente a sátira da literatura romântica e do comportamento correspondente na vida real” (1977a, p. 421). Como afirma Antônio Soares Amora, seu “[...] espírito crítico, independente e sutil, $[. .$.$] lhe permitiu surpreender [...] algumas das principais$ mazelas da época: [entre elas] o ridículo de uma postiça sentimentalidade amorosa 'romântica', aprendida pelos jovens nos romances europeus e considerada por eles a última moda" (1973, p. 221). Assim, concordamos com Boechat, que defende que devemos reconhecer,

[...] em sua veia cômica, uma posição consciente em relação à tradição romântica europeia. Nessa perspectiva, A moreninha constituiria uma apropriação irônica dos modelos sentimentalistas, só chegando a poder compor uma "poética do sentimento" - a partir da qual tem sido interpretado - porque sabe rir de sua própria "ingenuidade". Reconhecer essa dimensão do romance, entretanto, exige que o elemento cômico seja também reconhecido como mais do que um elemento superficial da trama: como uma estratégia eficiente e legítima da ironia romântica ${ }^{16}$, tal como seria ativada pela geração poética posterior. (2005, p. 128-129).

\footnotetext{
${ }^{16}$ Discutiremos a questão da ironia romântica no capítulo de Conclusão.
} 
Em suma, é interessante notamos que A Moreninha, apesar de tratar do amor, tema caro ao romance sentimental, não promove o arrebatamento das emoções, que sempre acabam sendo interrompidas pelas digressões jocosas do narrador, que, por sua vez, não se comove com o sofrimento dos personagens, visto mais como reações exageradas de enamorados. Contribuindo para essa perspectiva distanciada, temos as diversas passagens em que o narrador ridiculariza o herói romântico, impedindo que o leitor se identifique com suas agruras. A heroína, por outro lado, em muito se distancia da imagem típica de mulher romântica, sendo inteligente, desenvolta e insubmissa. Assim sendo, é preciso que deixemos de tratar o romance macediano como uma reprodução dos moldes romanescos importados em solo nacional. Ele, ao contrário, contém a crítica aos lugares-comuns do romance sentimental dentro de sua própria diegese, que supostamente adere aos modelos, ao mesmo tempo que os questiona e ridiculariza ${ }^{17}$.

${ }_{17}^{17}$ Deixaremos para refletir sobre as semelhanças entre o romance macediano e o camiliano na Conclusão. Optamos, igualmente, por fazer o mesmo com as obras analisadas nos capítulos seguintes. 


\section{Além da paisagem nacional: a (ausência da) descrição em narrativas de viagem}

Presença marcante no imaginário em língua portuguesa desde as navegações, a literatura de viagens - cujo representante máximo é a epopeia camoniana - também foi muito consumida durante o Oitocentos. A primeira metade do século XIX assistiu à difusão - tanto no Brasil quanto na Europa - dos relatos de viagem realizados por naturalistas e historiadores estrangeiros em terras americanas, como a Viagem Pitoresca e Histórica ao Brasil, de JeanBaptiste Debret; as diversas obras de Ferdinand Denis, como Le Brésil, ou Histoire, mœurs, usages et coutumes des habitans de ce royaume, escrito em parceria com Hippolyte Taunay; e as várias Viagens de Auguste de Saint-Hilaire. Mais tarde, já no campo da literatura, o sucesso de obras como Viagem à Espanha, de Théophile Gautier (1843), e Impressões de Viagem, publicada por Alexandre Dumas na década de 1850, impulsionou os escritores portugueses e brasileiros a se aventurar nesse subgênero.

Flora Süssekind destaca o Diário da Viagem ao Rio Negro (1861), de Gonçalves Dias, os Excertos das Memórias e Viagens do Coronel Bonifácio de Amarante (1848), de Araújo Porto-Alegre, a "Carta ao meu Amigo Dr. Cândido Borges Monteiro" (1833) e o Episódio da Infernal Comédia ou da Minha Viagem ao Inferno (1836), de Gonçalves de Magalhães, A Carteira de Meu Tio (1855) e Memórias do Sobrinho de Meu Tio (1867-68), de Joaquim Manuel de Macedo $^{1}$ (Cf. SÜSSEKIND, 1996b, p. 96), como representantes do subgênero no Brasil. Já em Portugal, de acordo com Carlos Reis,

Registrem-se [...] os seguintes autores e títulos, merecedores de referência no presente contexto: A. P. Lopes de Mendonça, autor de Recordações da Itália

\footnotetext{
${ }^{1}$ Ressalvamos que, para Süssekind, essas últimas cinco obras realizam um diálogo crítico com os relatos dos viajantes franceses: "especialmente em algumas expedições imaginárias ou humorísticas que, parecendo orientar-se segundo a retórica característica ao gênero, servem, na verdade, de duplos críticos dos relatos propriamente ditos" (1996b, p. 96).
} 
(1852-1853); [...] F. Maria Bordalo, que apresenta Um Passeio de Sete Mil Léguas (1854), de Lisboa a Cantão [...]; J. César Machado, folhetinista prestigiado que deixou umas Recordações de Paris e Londres (1862), Em Espanha (1865), Do Chiado a Veneza (1867), em que assume a condição desenvolta e algo superficial do touriste, como então se dizia; o visconde de Benalcanfor (Ricardo Guimarães), autor de Impressões de Viagem. Cádis, Gibraltar, Paris e Londres (1869), Na Itália (1876), De Lisboa ao Cairo (1876). (1997, p. 356).

Ao depararmo-nos, por outro lado, com um anúncio na Gazeta Ilustrada: o Ateneu Artístico-Literário, publicado no Porto em 1881, é possível observarmos que esse tipo de narrativa continuou sendo bastante apreciado pelo público até, pelo menos, a década de 1880:

O Jornal de Viagens e Aventuras de Terra e Mar, edição Ferreira de Brito, é uma das publicações que mais acolhimento tem tido em Portugal, tendo sido o primeiro jornal geográfico que apareceu no nosso país, educando os espíritos sem esforço e violência, com leitura amena, aprazível.

Os leitores do ilustrado semanário têm acompanhado, sem sair de casa, e sem se exporem às intempéries dos climas, - as explorações de Stanley, Livingstone, Serpa Pinto, Ivens, Brito Capello, etc.;- têm assistido a grandes caçadas pelas regiões longínquas, têm visitado as grandes capitais do mundo moderno e do mundo antigo, têm visto os usos e costumes, as guerras e religiões dos diversos povos, têm feito excursões aos vulcões mais célebres, têm atravessado os continentes e os mares, plenamente descansados nas suas cadeiras de braços sem o mais pequenino incômodo. É assim que se educam todos os espíritos que têm o desejo de saber, e que procuram desenvolver a sua inteligência por uma leitura que não fatigue e não aborreça.

O Jornal de Viagens vai entrar no seu $3^{\circ}$. ano, e espera continuar a merecer o mesmo aplauso e a mesma coadjuvação que tem merecido até hoje. (1881, p. 187).

A partir deste anúncio, depreendemos algumas das características que faziam as narrativas de viagem atraentes aos leitores: o assunto "ameno" e, portanto, voltado ao entretenimento; as viagens aventurescas a outros países e regiões exóticas; o relato da cultura e dos costumes de outros povos; o intuito didático. Como esclarece Carlos Reis, o homem romântico, em conflito com os valores burgueses pautados pelo materialismo e pelo modo de vida urbano, procurou deslocar-se - ao menos no âmbito literário - "para regiões 
caracterizadas pelo seu exotismo" (1997, p. 354), valorizando a natureza e a vida campesina, interessando-se "por figuras míticas como o bom selvagem, cuja pureza e vigor se devem justamente à não contaminação pelos vícios da sociedade europeia, urbana e burguesa" (1997, p. 354).

Se a evasão romântica costumava ser buscada pelos escritores a partir do relato de viagens a outros países, deslocando os seus olhares para regiões consideradas exóticas e distantes do modo de vida burguês, há outros autores que optaram pela descoberta da própria nação, retratando aquilo que ela teria de mais exótico: o campo, no caso de Portugal representado nas Viagens na Minha Terra (1846), de Almeida Garrett ${ }^{2}$-; a floresta e o interior do país, no caso do Brasil. Segundo Süssekind, "a própria afirmação de uma literatura nacional estava vinculada à repetida representação desses 'quadros naturais eufóricos' do país" (1990, p. 189).

Carlos Reis explica que a descrição é uma das principais características desse tipo de narrativa, uma vez que, "ao atribuir ao espaço a importância de fato reconhecida ao mundo novo que se encontra no caminho do viajante-narrador, a narrativa de viagens privilegia uma atitude intensamente descritiva" (1997, p. 355, grifo do autor). De acordo com Süssekind, “percorrer o país, registrar a paisagem, colher tradições: esta a tarefa não só dos viajantes estrangeiros que visitam e definem um Brasil nas primeiras décadas do século passado [XIX], este o papel que se atribuem também escritores e pesquisadores locais à época" (1990, p. 55). Em outro estudo, a pesquisadora exemplifica: "nada mais breve, objetivo, por exemplo, do que o Diário da Viagem ao Rio Negro, de Gonçalves Dias [...]. [Nele] coletam-se, com

\footnotetext{
${ }^{2}$ Sabemos que Viagens na Minha Terra não é uma ingênua narrativa de viagem convencional, uma vez que o autor dialoga com os pressupostos do romantismo, refletindo sobre a política portuguesa e a criação ficcional: "Garrett procura (e de um modo geral consegue) escapar a essa convencionalidade, antes de mais porque a sua viagem é plural: ela não se reduz a um trajeto físico, completando-se com outras 'viagens' (pela História, pelas tradições populares, pela Literatura, pela vida social, também pela novela da 'Menina dos Rouxinóis', etc.); por outro lado, a viagem garrettiana assume-se ideologicamente como viagem ao interior de Portugal (como o título do relato acentua), em detrimento de um exotismo algo estereotipado já.” (REIS, C., 1997, p. 355). Assim, não podemos negar que, através da descrição da passagem por vilarejos e dos costumes do povo, o autor emula os moldes importados das narrativas de viagem, substituindo as aventuras em países exóticos pelo exotismo do próprio país.
} 
cuidado, mas sem maiores interpolações, horários exatos, distâncias, itinerários, povoados, vistas, variações atmosféricas, expressões indígenas" (1996b, p. 96). Em seus Ensaios Críticos, publicados em 1866, Pinheiro Chagas elogia Júlio César Machado:

É nas impressões de viagem, publicadas agora nas Cenas da minha terra, que isto se torna mais sensível. [...] É Julio Machado o touriste mais caprichoso, que eu conheço; qualquer coisa o enleva, qualquer coisa desperta nele o sentimento do belo! Aqui a imagem de santa Madalena no Bussaco dá-lhe assunto para um trecho admirável, mais adiante é uma rapariga do povo na Foz, que o transporta às regiões do idealismo, depois são as rendeiras de Peniche, que o encantam, que o comovem, e fazem desabrochar no seu espírito as flores mimosas da poesia! Que tendência que ele tem para poetizar a mais leve coisa, e que habilidade para interessar o leitor por tudo o que interessa a sua imaginação romanesca. É delicioso viajar assim com ele em espírito, e é sempre, sempre com prazer, que releio aquelas páginas cheias de mimo, e de encanto. (1866, p. 103-104).

Neste excerto, Chagas explicita o que seria mais apreciado numa narrativa de viagem oitocentista: a descrição de curiosidades da paisagem e do povo a partir de uma perspectiva eufórica, contribuindo para a valorização da nação, ao despertar a comoção do leitor com a beleza de sua terra. Como explica Carlos Reis, “no tempo do Romantismo, já não se trata exatamente de descobrir espaços novos, do ponto de vista puramente geográfico; trata-se antes de compensar, pela viagem, estados emocionais tipicamente românticos" (1997, p. 354). Lembrando-nos do anúncio que retiramos da Gazeta Ilustrada de 1881, era também esperado do subgênero que educasse "todos os espíritos que têm o desejo de saber, e que procuram desenvolver a sua inteligência por uma leitura que não fatigue e não aborreça" (1881, p. 187). Nas palavras de Süssekind, os relatos de viagem interessavam "não apenas como divertimento, mas, sobretudo, como meio de conhecimento, educação e acesso a informações históricas, geográficas e sobre os usos e costumes, de outros povos” (1990, p.77).

Para tanto, era necessário valer-se da digressão, como um recurso narrativo para a divulgação não somente de informações, mas também dos ideais românticos - plasmados na 
valorização da nação e no suscitar das emoções. Segundo Carlos Reis, com frequência nas narrativas de viagem a descrição "alterna ou completa-se com outro registro discursivo, matizando-se em função da sua utilização: a digressão" (1997, p. 355, grifo do autor), que

[...] provém de um sujeito propenso a inscrever-se no discurso que enuncia, ao mesmo tempo que formula reflexões pedagógico-doutrinárias adequadas às preocupações ideológicas e às motivações éticas do homem romântico. Em certa medida, a digressão pode ser entendida como variação metonímica da narrativa de viagens: o sujeito em digressão física e geográfica transfere para o interior da sua capacidade de reflexão a dinâmica da viagem e empreende outra "viagem": uma "viagem" de natureza ideológica e de intenção didática, autorizada pela experiência adquirida e constituída por digressões intelectuais, através de temas descobertos a partir da primeira (e propriamente dita) viagem. (1997, p. 355, grifo nosso).

Dessa forma, procuramos aqui discutir sobre as características valorizadas nos relatos de viagem durante o século XIX, corroboradas em excertos da época. A partir de sua leitura, é possível depreendermos as expectativas do público oitocentista e, portanto, os modelos considerados "ideais" desse subgênero, reproduzidos por grande parte dos autores do período. Com isso, pretendemos, a seguir, analisar as narrativas de viagem criadas por Camilo e Macedo, a fim de verificarmos a forma como esses escritores se apropriaram do sucesso conferido ao subgênero, desviando-se de seus preceitos. 


\subsection{Vinte Horas de Liteira na superfície escabrosa do globo}

Publicado por Camilo Castelo Branco originalmente em folhetins, em 1864, Vinte

Horas de Liteira: romance original foi lançado em volume no mesmo ano (Cf. RITA, 2002,

p. XI). Apesar de não ter sido uma das obras mais vendidas do autor, também não foi completamente ignorado: sua segunda edição saiu em 1890 (Cf. MARQUES, H., 1925, p. 208). Em Ensaios Críticos, Pinheiro Chagas defende que se coloque o romance em “[...] um lugar de honra em todas as bibliotecas na prateleira onde estiverem colocadas as Viagens na minha terra [...]" (1866, p. 51). Em outro momento, ele afirma:

Que me dizem, por exemplo, de Plinio, o naturalista, morrendo intrepidamente, vítima do desejo que tinha de legar à posteridade mais um romance científico? Que me dizem do falecimento heroico desse grande homem, cuja ambição única era ver de perto uma erupção do Vesúvio, para ter a certeza de que nem uma palavra só que escrevesse a esse respeito fosse verdadeira? Que me dizem de Fernão Mendes Pinto sujeitando-se a ser engolido pelas ondas rugidoras, empalado pelos chinas, espatifado pelos malaios, a fim de escrever o mesmo que podia escrever perfeitamente sem passar de Cascais? Que me dizem de Alexandre Dumas viajando no Egito, arrostando os ardores do sol africano, as vagas de areia levantadas pelo khamsim, os dentes ferozes dos crocodilos, as angústias da sede, as zombeteiras torturas da miragem, tudo isto depois de já ter deixado em Paris o livro descritivo da sua peregrinação, tudo isto para que a sua consciência lhe não pudesse lançar em rosto um dia a ocasional fidelidade de um episódio? Que me dizem finalmente de Camilo Castelo Branco suportando vinte horas de liteira, para ouvir as histórias, que deviam compor esse formoso volume [...]. (1866, p. 33-34, grifo nosso).

Neste trecho, Chagas é irônico com relação à suposta verdade contida nos relatos de viagem, introduzindo uma crítica que faria na década seguinte, em 1878, quando notou, em parceria com Júlio César Machado, "no prefácio do volume Fora da Terra, uma inflação de relatos de viagens que anunciava o cansaço do gênero" (Cf. REIS, C., 1997, p. 356). Assim como, para Chagas, as aventuras inverossímeis de Plinio, Fernão Mendes Pinto e Alexandre 
Dumas não foram realmente vividas por esses escritores - o primeiro não escrevera "nem uma palavra que fosse verdadeira"; o segundo nunca teria saído de Portugal, uma vez que supostamente viajando, escrevera "o mesmo que podia escrever perfeitamente sem passar de Cascais"; e o último teria escrito o livro em Paris, mesmo alegando ter viajado para confirmar as informações -, o crítico também não crê que Camilo efetivamente tenha recolhido as histórias do seu romance numa longa viagem de liteira. Entretanto, em seu depoimento é possível verificarmos que Vinte Horas de Liteira foi recebido, na época, como um típico representante das narrativas de viagem convencionais. De acordo com Esther de Lemos, “menos sensíveis do que nós, leitores modernos, aos problemas técnicos da Literatura, os contemporâneos viram porém nele sobretudo o modelo de um gênero coloquial, de crônica de viagem, folhetinesco sem mau sentido, primoroso na sua ligeireza recreativa" (1966, p. 34$35)$.

Contudo, ao lermos o romance camiliano mais detidamente, acabamos por encontrar um quadro bastante diverso. Logo de início, o que nos chama a atenção nessa obra não é a presença de determinado elemento, mas a ausência da descrição da paisagem, da natureza - em suma, da cor local. Nesse caso, a ausência da descrição é um fator importante a ser analisado, uma vez que a atitude descritiva é justamente a característica fundamental do gênero narrativa de viagem. Não por acaso, a ausência da descrição é compensada pela supremacia da digressão - e podemos dizer que o romance é composto, na verdade, de uma longa digressão: nele, a viagem é acessória, e a paisagem nacional praticamente não aparece.

Nessa obra, o narrador - que sugere ser o próprio Camilo, um expediente retórico utilizado em muitos de seus romances - faz uma viagem cruzando o interior de Portugal sem nenhum motivo extraordinário: ele não quer desbravar o país, estudá-lo ou promover o seu conhecimento entre os leitores, mas simplesmente se dirigir de Vila Real ao Porto, um centro urbano. No romance, a digressão assume o lugar privilegiado da narrativa, uma vez que a 
viagem serve de pretexto para o diálogo entre o narrador e o personagem António Joaquim, que o acompanha dando-lhe carona em sua liteira - um diálogo entremeado com relatos de várias histórias distintas, contadas pelo personagem-acompanhante.

Com um mote prosaico, o autor não dá espaço para a aventura e nem mesmo para o relato de costumes do povo ou de curiosidades do país. Pelo contrário, quando o povo português é retratado no romance, é criticado por sua ignorância, suas superstições e seus preconceitos, distanciando-se da perspectiva nacionalista típica das narrativas de viagem: “o povo, romancista descabelado, inventara que as almas dos padres [...] andavam penando em volta da casa" $\left(V H L^{3}\right.$, p. 1010, grifo nosso). Em um dos contos, uma personagem pretende vingar-se da crueldade com que fora tratada pelos conterrâneos, por ter se apaixonado por um soldado francês durante a invasão napoleônica: “[...] todos os maiores de cinquenta anos se conjuraram, há quarenta, para me queimarem a casa. Necessito vingar-me cristãmente destes patriotas, que quiseram oferecer no altar da Pátria às divindades portuguesas minha mãe assada" (VHL, p. 1022). A invasão napoleônica em Portugal, aliás, é chamada de "a mais ignóbil das lutas da sua carreira de triunfos [do soldado francês]" (VHL, p. 1021), o que mostra a pequena importância da nação lusa perante o restante da Europa, fato reconhecido pelo narrador.

É na voz de António Joaquim que encontramos o único trecho de descrição da paisagem nacional, seguindo as convenções do gênero, com a valorização ufanista do campo: "Da crista do monte descobrem-se verdadeiros tesouros, fertilíssimas campinas, povoações a branquejarem por entre florestas, bosques coroados pelas agulhas das torres, rios que serpenteiam por entre almargens e ervaçais, enfim, o Minho, o espetáculo prodigioso, que faz amar Portugal” (VHL, p. 1051). Tal descrição, no entanto, se contrapõe à imagem depreciativa que o narrador camiliano faz do mesmo espaço, alguns capítulos depois, mostrando o seu

\footnotetext{
${ }^{3}$ Ao longo deste trabalho adotaremos a sigla VHL sempre que citarmos o romance Vinte Horas de Liteira, de Camilo Castelo Branco. As citações são retiradas do volume IV das Obras Completas (1985).
} 
olhar desdenhoso perante a euforia nacionalista presente na apologia à natureza e à vida campesina, típica das narrativas de viagem oitocentistas: “[...] nós embarcamos na liteira, cuja comodidade já me ia parecendo uma cousa problemática, depois de quinze horas de trajeto na superfície escabrosa do globo" (VHL, p. 1080, grifo nosso).

As histórias narradas pelo personagem-acompanhante sempre terminam com um ensinamento - o jogo leva as famílias à ruína, a ganância é fonte de infelicidade, a generosidade é recompensada, etc. -, característica que faria as digressões deste romance terem um caráter didático e doutrinário-pedagógico tal como o esperado numa narrativa de viagem tipicamente romântica. Entretanto, o moralismo de António Joaquim é contrastado com o seu caráter duvidoso, descrito com ironia pelo narrador camiliano, desvelando a sua hipocrisia: "Cria poldros [...], com os quais tem enganado os seus melhores amigos: cousa que não mancha de leve a reputação de quem quer que negoceia em poldros. Também engorda bois para Inglaterra, e estuda, entretanto, a inconveniência econômica da exportação dos bois" (VHL, p. 991). Ou seja, aquilo que o personagem afirma acreditar não é o que desempenha na prática. Em certa passagem, contradizendo as suas próprias narrativas, António Joaquim questiona a função educativa da literatura:

Sabes que eu leio os teus romances: é o máximo sacrifício que posso fazer-te das minhas horas de repouso. Em louvor dos teus livros, basta dizer-te que os leio. Prendem-me a curiosidade uns paradoxos de virtude que tu estendes a trezentas páginas. Já fizeste chorar minha mulher: quase que ma ias fazendo nervosa! Foi-me preciso dizer-lhe que tu mentias como dous ministérios, e que timbravas em ter um estilo de cebola ou de mostarda de sinapismos que faz rebentar chafarizes de pranto. Nem assim consegui desacreditar-te! Assim que sai romance teu, minha mulher, combinada com o editor, seca-me a paciência, até que o livro chega de Braga entre um papeliço de açúcar, e o saco do arroz. A pobre mulher começa a chorar no título; estrenouta-se a ler; e, ao outro dia, está desolhada, e amarela como as doze mulheres tísicas, que tens levado à sepultura num rio de lágrimas. (VHL, p. 994). 
Neste trecho autoirônico, temos a definição dos romances camilianos como meras mercadorias - vendidas "entre um papeliço de açúcar, e o saco do arroz" - voltadas para o entretenimento e o arrebatamento das emoções - segundo as expectativas de leitura dos romances sentimentais românticos -, contendo histórias distantes da realidade. A seguir, o personagem relata as dificuldades que teve para casar-se com sua esposa, numa picaresca história de amor contrariado, cuja comicidade rebaixa o tom sério que seria esperado de tal temática:

Fui grandemente contrariado no conseguimento da mulher, com quem casei. Minha mãe não queria desistir de me ver de mitra e báculo; meu pai aborrecia a moça, porque a vira trajada à moda da cidade, e lhe constava que ela vivia à lei da nobreza. O pai de Maria Clara aborrecia-se de mim, porque eu the matara a tiro umas pombas, cuidando que eram rolas maninhas; a mãe odiava-me outro tanto, porque eu pintara casualmente, na parede da igreja, uma cara com um nariz descomunal, e aconteceu que a mãe de Maria Clara possuía o maior nariz do concelho. Os gandaieiros da freguesia começaram a

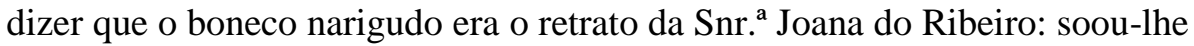
o boato; averiguou quem fosse o Apeles de carvão; e jurou que seu marido havia de ser papa, quando eu fosse bispo. (VHL, p. 998).

Ao fim do relato, António Joaquim conta que se livrou de ser morto pelo antigo namorado de Maria Clara graças à sua égua, que empacou e não deixou que ele fosse surpreendido por uma emboscada: o animal teria sido, assim, o responsável pela sua salvação. Camilo-narrador, entretanto, reproduz os lugares-comuns da narrativa sentimental, mostrando como tornar essa história mais romanesca e, portanto, mais palatável ao gosto do leitor:

Eu creio que foram as orações de tua mãe que te salvaram [...]. Foi uma mulher que te salvou, meu caro António Joaquim; mas mulher-mãe, intercessora, cujos requerimentos justos nunca descem indeferidos do tribunal divino. Pois, se me dissesses que, à mesma hora, a Snr. ${ }^{a}$ D. Maria Clara, tua noiva, esperançosa metade de tua alma, estava orando por ti - e bem pode ser que estivesse -, dir-te-ia eu que foram duas as mulheres a salvar-te. Um anjo - concede que eu diga um anjo, enquanto me não fechares as portas do Céu - levaria em uma de suas asas a petição da mãe, na outra a petição da virgem. (VHL, p. 1003, grifo do autor). 
Mostrando que de fato não se coaduna com esse tipo de discurso convencional, o narrador camiliano, em outro momento, interrompe a fala de António Joaquim, que reproduzia o linguajar sentimental - "ao primeiro alvor, cavalgaremos, saudados pelas avezinhas, que nos darão em trilos a orquestra da magnífica partitura da natureza, composta pelo sublime maestro que fez as harmonias dos bosques e as harmonias das esferas..." (VHL, p. 1118) -, ridicularizando-o e desvelando a sua artificialidade: “Que estilo! - interrompi eu atordoado com o rufo e repique deste palavreado. - Que estilo, santo nome de Jesus! O horror local fez-te perder a portuguesa e minhota simplicidade da tua linguagem! Pois, em verdade, essa gente falava assim?!...” (VHL, p. 1118). Páginas adiante, novamente com autoironia, manipulando a sua própria imagem como escritor misantropo, Camilo-narrador critica o excesso de melodrama, típico do romance sentimental, utilizado pelo personagem em seu relato:

- Que tristeza de história! - atalhei eu. - Não ta pedi tão sentimental!... [...] carrega o menos que puderes as cores negras. Esse teu estilo vai-se parecendo com o meu. [...] De repente, despenhas a minha expectativa nuns andrajos em que morre uma mulher desvalida com uma filhinha aconchegada do seio morto!... Ora, pelo amor de Deus!... és muito pior romancista que eu!... Se tu visses em que conjunturas eu tenho escrito as novelas, que fazem chorar tua senhora!... Basta dizer-te que escrevo sempre à luz do crepúsculo. Os meus olhos não comportam outra luz. Quando os dias estão lucidíssimos do brilhantismo do sol, eu tomo do favor de Deus a frouxa claridade de um raio coado por transparentes negros. O meu gabinete de trabalho, durante os meses esplêndidos do ano, é um continuado começo de noute. Desta escuridade, muitíssimo de entristecer, difundida em volta de mim, de força a minha imaginação há de sentir-se [...]. Tu, porém, meu amigo, tão feliz, tão sadio de olhos, tão em contato com o sol, com as árvores, e ribeiros, e flores, onde aprendeste essa linguagem plangente?! (VHL, p. 1026).

Em seguida, o diálogo entre o narrador camiliano e seu acompanhante desvela a falsidade dessa imagem funesta, cultivada pelo romancista como forma de propaganda: assim como a sua poesia, sua misantropia é artificial e distante da realidade: 
- [...] Essa tolice é muito mais sincera que outras maiores que se escrevem nas cidades.

- É o que eu ia dizer, se o não dissesses tu: e o primeiro exemplo, que me acudia à memória, eras tu mesmo.

- Eu?! obrigado!... Aproveito a ocasião de saber quando fui mais tolo que o Snr. Lourenço Pires [personagem do conto narrado por António Joaquim].

- Quando escreveste e publicaste uma poesia com estes três versos:

Sou um mártir do amor;

Sou um anjo sofredor;

Nem um prazer me sorri!

Isto é teu?

- Deve ser: não há parvoiçada que eu não tenha escrito.

- Pois bem: Lourenço Pires, dizendo que era pintassilgo, foi menos irrisório que tu, dizendo que eras anjo. Anjo, tu!... que anjo!... No tempo em que decretaste a tua angelização, foi que eu te conheci a comer ostras cruas na Águia de Ouro. Olha se te lembras!... Comecei então a descrer dos poetas, e a crer nas ostras...

- Lembro-me muito bem, meu amigo. Foi então que eu estraguei o fígado e o baço. Os três versos, que ultrajas com sensata ironia, revelam amolecimento de cérebro. (VHL, p. 1027, grifo do autor).

Em outro exemplo de autoironia, temos o capítulo em que António Joaquim anuncia que irá relatar a história de um enjeitado. Lembrando que o próprio escritor publicou várias obras com essa temática, verificamos que nessa passagem Camilo-narrador ridiculariza os lugares-comuns do romance sentimental romântico que, segundo ele, carecem de imaginação, por repetirem as mesmas matérias:

Estás dedilhando as cordas todas da lira dos modernos romancistas e dramaturgos - observei eu. - O enjeitado é uma rica exploração que há vinte anos faz gemer os prelos e chorar a gente. Desde o Martin de Eugênio Sue até ao teu enjeitado, que não sei como se chama, a simpatia, que eles conquistam, não há filho nenhum legítimo que mereça. Este fato demonstra a desmoralização da época, se não demonstra primeiramente a esterilidade das fantasias. Os escritores andam à competência com as amas em irem à roda procurar expostos. Depois, pegam das criancinhas, e dão com elas, defecadas de doença e fome, na cara da sociedade. (VHL, p. 1057).

Já em outra passagem, António Joaquim anuncia que irá contar uma história de terror, ao que Camilo-narrador afirma, troçando com a literatura consumida na época: "Dous cadáveres!... Esta casa dá títulos para os romances de Frederico Soulié...” (VHL, p. 1117, 
grifo do autor). Ao descrever a fisionomia que o personagem faz ao narrar o conto, o narrador camiliano despe-o da seriedade necessária para garantir a fruição da atmosfera tétrica, ridicularizando-o: “António Joaquim vestiu de horror o semblante, esbugalhou os olhos empedrados de pavor, e disse no tom soturno dos celerados, que aterram a gente no teatro com histórias medonhas" (VHL, p. 1117). Assim, para Camilo-narrador, a narrativa de terror é motivo de riso: “Que imagem! - observei eu. - Também me sinto quebrar pela espinha dorsal às garras da tua retórica. Tens vislumbres de Victor Hugo! [...] Estou a crer que esse estilo é a vitela de Baltar que o dá” (VHL, p. 1119). O fim da história, aliás, quebra as expectativas de leitura e traz uma resposta prosaica para o mistério das assombrações: "eram grosas de esquadrões de percevejos, que irrompiam em caravanas das cavernas do catre, e das luras do tabique" (VHL, p. 1120).

É também emblemático o trecho em que o narrador camiliano parodia os moldes do romance histórico. Antes de ele dedicar quase três páginas às mais remotas origens da cadeia da Relação do Porto, cujo conhecimento não interessa nem influencia o relato que será contado por António Joaquim, encontramos uma crítica irônica ao fervor dos escritores em descrever a História, em detrimento da história:

\begin{abstract}
Abre-se um entre parênteses na narrativa do meu amigo para de passagem [lembramos que são três páginas] referir ao leitor, não informado, a procedência daquele quadrilátero de granito denegrido, que ali está na Porta do Olival. E, se o leitor, aborrecido de velharias, se anojar com a história da Relação do Porto, dê um salto de olhos sobre três colunas do folhetim, e prenda a sua atenção no ponto em que António Joaquim é interrompido.

Antes do nascimento de Cristo, 226 anos... - Vejam onde eu vou! Pouca gente começa de tão longe nestes tempos em que o progresso nos está empurrando a todos para diante! (VHL, p. 1069, grifo nosso).
\end{abstract}

Ao longo do quase interminável relato dos pormenores históricos da cadeia, o narrador camiliano ri-se, prevendo a reação de seu público: “Estou a ver o desfastio adorável com que alguns centenares de leitoras deixam cair o jornal, e murmuram no tom dos anjos 
agastados: - Que impertinência! Que narcótico!” (VHL, p. 1070). Em outro capítulo, Camilonarrador pretende encetar uma reflexão filosófica acerca da História do boi:

- Principiando um pouco depois do dilúvio - tornei eu -, saberás que os bois, entre os egípcios, os fenícios, e indostânicos...

- Eram bois - atalhou António Joaquim. - A consideração, que me mereces há muitos anos, e a franqueza com que me tratas, anima-me a pedir-te que me não digas nada da importância do boi na Fenícia, no Egito, e no Indostão. As liteiras são locomotivas próprias e talhadas para esses e análogos discursos [...]. (VHL, p. 1123).

A partir da fala de António Joaquim, temos a crítica ao próprio subgênero narrativa de viagem - simbolizado na liteira -, o qual é repleto de digressões compostas por reflexões filosóficas, muitas vezes inúteis e risíveis, como a que Camilo-narrador, ironicamente, ameaça fazer. A história dos bois, por sua vez, relatada pelo personagemacompanhante, imita a emotividade exacerbada do romance sentimental - com a ressalva de que se trata não da história de amor de uma moça para com o seu namorado, mas para com os seus bois. No final, o narrador camiliano ri-se do conto: “A tua vizinha - disse eu -, enquanto a mim, se não é fabulosa como a Pasifaé, tem instintos e coração de vaca! Perdoa-me, se não choro enternecido com a tua história" (VHL, p. 1127). Para o personagem, por sua vez, o escritor é insensível, "um espírito fútil” (VHL, p. 1135), que "só entende[...] o amor ao boi, desfeito em bifes ou almôndegas" (VHL, p. 1127).

Assim, encontramos nesse romance a contraposição entre dois pontos de vista: o de António Joaquim, um narrador que tira lições edificantes a partir da observação de casos e costumes, e o de Camilo-narrador, que ridiculariza tais procedimentos. É possível, por exemplo, encontrarmos numa passagem uma crítica direta às reflexões didáticas e pedagógico-doutrinárias presentes nos relatos do personagem-acompanhante e típicos do romance romântico português, representado aqui por José Rodrigues Bastos - o escritor do maior sucesso editorial dos anos 1840-60 em Portugal, A Virgem da Polônia (Cf. OLIVEIRA, 
2008b, p. 3). Camilo pode até utilizar essas máximas em suas obras, porém, não as leva a sério; como revela António Joaquim, o autor só utiliza os aforismos com o intuito de preencher linhas, quando não tem mais o que escrever:

- Parece que te enfadam estas máximas!... [...] Pois sim: eu vou direto ao ponto, visto que não é lícito imitar-te na manha com que tu, nos teus romances, ensartas axiomas, quando a imaginação te emperra.

- Agradecido... Não se pode ser La Rochefoucauld sem ter-se a fantasia perra!... Tu e os leitores da tua laia é que afogam os embriões dos escritores aforismáticos em Portugal. Pois sabe tu que a eternidade de muitos livros é o estilo sentencioso que lha dá. Os romances vão a pique, às vinte e quatro horas de navegação, porque não levam lastro de sentenças. Entre nós, há um exemplo da duração de um renome, devido à gravidade das máximas: são os romances do conselheiro Rodrigues Bastos. É, todavia, necessário que o escritor seja maior de oitenta anos para que os leitores lhe relevem o tom pedagógico dos axiomas... (VHL, p. 1075-1076).

Como o narrador camiliano zomba, em certo momento, ao ser instado a contar

uma história, a literatura não passa de mercadoria: "Eu costumo vendê-las [as histórias] respondi com o grave e sisudo desinteresse da arte. - Contava-te um conto bonito, se me desses este brilhante, que me vai cegando como o resplendor de Jeová ao povo escolhido" (VHL, p. 1086). Após ele relatar o conto que prometera,

António Joaquim fez-me o favor de achar engraçada a minha história, e perguntou-me quanto devia, visto que a minha profissão era vender histórias. Conspiraram poderosos sentimentos de gratidão para que eu, com o desprendimento do filósofo que rejeitou os tesouros de Xerxes, lhe dissesse que não era nada. Sem embargo da minha recusa, António Joaquim deu-me um cigarro, e perguntou-me se os editores em Portugal eram mais liberais do que ele. Pude convencê-lo de que os editores em Portugal eram as hóstias imoladas espontaneamente nas aras das letras pátrias, e que eu, à minha parte, havia arruinado uns poucos, e os meus colegas o resto, de teor e modo que, volvidos alguns anos, os poetas e romancistas, se não pudessem viver repletos e entouridos das suas fantasias, haviam de ir às praças, à imitação de Homero, narrar os seus poemas e romances às multidões, que, em paga, lhes enramariam as frontes de acácias e cilindras. (VHL, p. 1116). 
Assim, a profissão de escritor é vista como o pior dos ofícios, cuja falta de dinheiro é representada pela constante magreza do narrador camiliano, como nota o seu amigo: "Estás magro, homem! [...] Deixa-te desse modo vivente, se não aspiras à mumificação" (VHL, p. 993). Ao comentar a história de um conhecido que enlouquecera António Joaquim creditara o fato a um amor não correspondido; Camilo-narrador, à pobreza -, aquele afirma que o rapaz deveria ter se tornado escritor, ao que este responde: "Ouvindo isto, benzi-me, pus os olhos no Céu, e disse: - A Providência divina houve por bem endoudecê-lo pelos processos ordinários da loucura vulgar, antes de lhe incutir a loucura extraordinária de fazer-se escritor em Portugal” (VHL, p. 1139).

Com isso, o autor mostra que o assunto principal de Vinte Horas de Liteira não é a viagem, mas a própria literatura, sob vários aspectos: a profissão de escritor; o papel edificante (ou não) da literatura; as expectativas do leitor - e como utilizá-las para vender a sua obra como uma narrativa de viagem, mesmo que ela não seja, ou que seja mais do que isso. O romance dialoga explicitamente com a Viagem ao Redor do Meu Quarto (1794), de Xavier de Maistre:

O benigno acaso honorificara-me, naquele tempo, com uma posição insociável, análoga à de Xavier de Maistre, quando viajou à roda do seu quarto. O sublime filósofo escreveu então o mais desenfastiado e gracioso livrinho deste mundo. Bem haja a polícia de Turim, que circunscreveu os horizontes do autor do Leproso às quatro paredes de uma câmara, em cujo ambiente as ideias de ouro ondulavam com a poeira lampejante sob um raio de sol. A humanidade não teria aquele livro da saudade, do coração, e do conforto, se a culpa do escritor o não forçasse à reclusão [...].

As cortinas do meu quarto não eram as inspirativas cassas branca e rosa do gentil narrador: eram transparentes-opacos de fábrica nacional, que desfiguravam a luz em escureza de cárcere. Os quadros independentes de quatro pregos eram o retrato de quatro pessoas infelizes: uma mulher sentada no cairel de um abismo, sondando-lhe a profundeza para despenhar-se. $\mathrm{O}$ segundo era dois noivos de oito meses fechados na sepultura antes de verem florir a primeira primavera debaixo do céu, em que eles se tinham abraçado para caminharem, longa vida, à luz da mesma estrela. $\mathrm{O}$ terceiro quadro era um artista, vencido na luta com a miséria, dando o seu único bocado de alimento a um cão, o só amigo seu, e certo para a hora suprema de agonia, figurada no último quadro. Com estes incentivos chora-se; mas não se viaja. (VHL, p. 1140-1141). 
Neste trecho, o narrador camiliano compara os processos de criação literária de Xavier de Maistre com os dele mesmo, escritor pobre num país insignificante perante o resto da Europa, repleto de injustiças e misérias, como ele mostrou nas diversas histórias narradas por António Joaquim, e exemplificadas aqui nos quadros que figuram pessoas desgraçadas. Nessa passagem, a inferioridade de Portugal está plasmada nas cortinas "de fábrica nacional" do narrador, que tornavam o quarto escuro, aparentemente por serem de qualidade inferior às do escritor francês. Nesse sentido, Camilo demonstra compreender que o resultado de uma obra escrita no contexto social português não teria como ser o mesmo de uma obra escrita na França. Como explica a teoria de Roberto Schwarz sobre "as ideias fora do lugar", não haveria como fazer um romance como o de de Maistre em Portugal: ele acabaria soando falso e artificial. Segundo o narrador camiliano, a tão decantada "inspiração" romântica - que teria motivado a obra do autor francês - não o arrebata: para ele, é impossível "viajar", quando se tem tantos quadros de infelicidade na vida real.

Além disso, de Maistre escreveu no final do século XVIII, numa época ainda não contaminada com os excessos do romantismo - simbolizados pelas figuras maceradas dos retratos, que também representariam os lugares-comuns do sentimentalismo romântico -, os quais Camilo precisava utilizar em seus romances para que fossem vendidos. Assim, tratar-seiam também de contextos culturais e literários distintos. Por outro lado, não necessariamente o escritor português se via como inferior ao francês: para ele, Viagem ao Redor do Meu Quarto é um "desenfastiado e gracioso livrinho", um "livro da saudade, do coração, e do conforto", características que se relacionam ao sentimento e à leitura amena e descompromissada. Apesar de o narrador camiliano afirmar o tempo todo que o seu romance não passa de mercadoria voltada ao entretenimento, o fato de reconhecer isso faz parte de seu processo autoirônico de reflexão crítica sobre a literatura - o que não é nada ingênuo. Como defende Carlos Reis, Vinte Horas de Liteira configuraria 
[...] um exemplo notável da capacidade de Camilo para refletir em plena maturidade dos seus dotes criativos, sobre a criação romanesca, sobre os seus processos dominantes, sobre a problemática da autoria, sobre as responsabilidades éticas, sociais e estéticas do escritor, tudo elaborado num registro simultaneamente dialógico e autocrítico. (1994, p. 113).

Nas palavras de Annabela Rita, "Camilo inscreve, assim, Vinte Horas de Liteira nessa linhagem estética desconstrucionista e autorreflexiva" (2002, p. XIV). Com isso, ao revestir a sua obra de aspectos que, em sua aparência, lembravam as narrativas de viagem convencionais, a fim de atrair o leitor que apreciava e, sobretudo, consumia esse tipo de literatura, Camilo se dedica, de fato, ao questionamento das formas de produção do romance romântico, em seus mais diversos subgêneros - a própria narrativa de viagem, o romance histórico, a narrativa de terror, o romance sentimental, etc. Com isso, percebemos que Vinte Horas de Liteira não se trata de mais um exemplar da literatura de viagens, mas de uma crítica, sem deixar de ser cômica, viagem pela literatura. 


\subsection{A Carteira de Meu Tio e isto de pátria, honra, lealdade, tudo é ficção, tudo é poesia}

A Carteira de Meu Tio foi publicada por Joaquim Manuel de Macedo em folhetins em 1855, a princípio anonimamente e depois em livro, já com a autoria, no mesmo ano, tendo sido uma das obras mais vendidas do escritor brasileiro, com cinco edições até o final do século XIX (Cf. SERRA, 2004, p. 335). No Dicionário de Literatura (1960) dirigido por Jacinto do Prado Coelho, A Carteira de Meu Tio é colocada entre as mais relevantes obras brasileiras representantes da literatura de viagens (Cf. 1981, p. 1161). Em seu estudo sobre as narrativas de viagem oitocentistas publicadas no Brasil, Flora Süssekind cita o romance macediano, conforme discutimos anteriormente, como um exemplar do subgênero, porém como "um duplo crítico" dos relatos de viagem propriamente ditos (Cf. 1996b, p. 96) ${ }^{4}$.

Ferdinand Wolf, por sua vez, em O Brasil Literário, publicado em 1863, refere-se a A Carteira de Meu Tio com o subtítulo "viagem fantástica"5 (Cf. 1955, p. 348), o que revela que a obra já havia sido recebida pela crítica e pelo público da época como um desvio da literatura de viagens convencional. Segundo este subtítulo indicava, o romance macediano tratava-se sim de uma narrativa de viagem, no entanto, "fantástica", isto é, distinta do realismo ${ }^{6}$ comumente esperado no subgênero. Como veremos, foi acertada a leitura de que a obra não seria mera imitação das narrativas de viagem consumidas no Oitocentos; todavia,

\footnotetext{
${ }^{4}$ A pesquisadora também cita as Memórias do Sobrinho de Meu Tio (1868), obra com a qual não iremos trabalhar aqui, pelo fato de a considerarmos mais próxima de uma paródia do subgênero da autobiografia do que da narrativa de viagem.

${ }^{5}$ Em nossa pesquisa, não foi possível encontrar o que motivou Ferdinand Wolf a denominar A Carteira de Meu Tio uma "viagem fantástica". Talvez o subtítulo estivesse presente na versão em folhetim, ou na primeira edição em livro, tendo sido depois retirado; talvez a denominação estivesse presente nos anúncios dos jornais da época, ou tivesse sido simplesmente criada por Wolf, como forma de definir o romance. De qualquer maneira, o que nos importa aqui é pontuar que na época a obra foi de fato recebida como um exemplar da narrativa de viagem, ainda que heterodoxo.

${ }^{6}$ Utilizamos aqui o termo "realismo" referindo-nos às descrições feitas pelos viajantes das paisagens reais, da realidade dos modos de vida dos povos, em contraposição ao termo "fantástico", que remete ao campo do imaginário.
} 
talvez o termo "fantástico" não fosse o mais indicado, uma vez que o romance é composto de uma crítica contumaz à política da época - e, portanto, através do seu caráter alegórico, carrega uma forte denúncia da realidade nacional.

A Carteira de Meu Tio é um suposto diário de viagem narrado pelo personagem autointitulado "sobrinho de meu tio", que, querendo seguir a carreira política com o patronato e a fortuna do tio, é impelido por este a viajar pelo Brasil, levando consigo a Constituição alcunhada por ele de "defunta" (Cf. $C M T^{7}$, p. 25), uma vez que suas leis não são cumpridas -, para estudar "o que convém ao teu país, no que se passa nele, e nos costumes do nosso povo" (CMT, p. 23), escrevendo as suas "impressões de viagem" (Cf. CMT, p. 25) na tal carteira. Para o tio, a única forma de se tornar um bom político é estudar "no livro da tua terra. [...] Refiro-me ao livro que só se pode ler viajando e observando" (CMT, p. 22), em vez de agir como grande parte dos estadistas brasileiros, que "empregam no Brasil uma governação que aprendem nos livros da França e da Inglaterra; improvisam no mundo novo as instituições do mundo velho, algumas das quais têm tanta relação com as nossas circunstâncias, como um ovo com um espeto!"' (CMT, p. 23).

Assim, através da voz do tio, Macedo defende que os políticos brasileiros devem buscar entender a raiz dos problemas pelos quais o povo passa e trabalhar para solucioná-los, em vez de tentarem aplicar no país uma política estrangeira, de imitação, fadada ao fracasso como "as ideias fora do lugar" teorizadas por Roberto Schwarz. Com isso, o autor mostra a sua consciência de que contextos sociais, econômicos e culturais distintos pedem ações políticas diferentes. Ao mesmo tempo, parece-nos que ele também sugere, através de seu romance, que tais contextos distintos também pedem uma literatura divergente. Como depreendemos do trecho citado, o tio defende a aprendizagem, a aquisição de conhecimento através da viagem - reproduzindo, assim, um dos principais lugares-comuns da literatura de

\footnotetext{
${ }^{7}$ Ao longo deste trabalho adotaremos a sigla CMT sempre que citarmos o romance A Carteira de Meu Tio, de Joaquim Manuel de Macedo. As citações são retiradas da edição publicada pela Livraria Garnier (2001).
} 
viagens, um subgênero importado. Se o sobrinho tivesse realizado a vontade do tio, provavelmente teríamos uma narrativa de viagem convencional, com a descrição das paisagens e a reflexão sobre os costumes locais. Entretanto, o romance macediano não cumpre essa expectativa.

Segundo Süssekind, o itinerário do narrador-personagem parece "marcado pela desterritorialização semelhante ao seu propositado anonimato autoral. Daí não ser possível indicar sequer o ponto de partida do sobrinho-do-tio com exatidão, contrariando a exigência característica às narrativas de viagem de dados geográficos precisos” (1996b, p. 105), como verificamos na passagem seguinte:

Sei muito bem que, segundo o uso de todos os meus colegas viajantes, e conforme os conselhos da boa razão, era do meu dever começar a importantíssima história da viagem, que já estou fazendo, pela determinação do ponto de onde parti; mas a casa de meu respeitável tio é uma espécie de velho castelo encantado, cuja situação geográfica não me é possível assinalar precisamente: eu podia sem dificuldade declarar que ela demora aos tantos graus, minutos e segundos de longitude tal, e tantos e quantos de latitude, entretanto, procedendo assim, não faria mais do que pregar uma tremenda peça aos meus queridos leitores: não desconheço que as narrações de todos os meus colegas viajantes, e principalmente as daqueles que têm andado pela nossa boa terra, contêm mais patranhas e mentiras do que os artigos de certos jornais políticos, e os programas de todos os ministérios; estou, porém, decidido de pedra e cal a seguir os conselhos de meu tio, escrevendo, na Carteira que ele me confiou, verdades e só verdades. (CMT, p. 28, grifo do autor).

Criticando os relatos de viagem - sobretudo os escritos por viajantes estrangeiros sobre os recônditos do Brasil, muito célebres na época -, o narrador afirma que não enganará o seu leitor, tal como esses escritores faziam, e obedecerá ao mandamento do tio: “[...] não escrevas parvoíces na Carteira de teu tio; estimo que sejas o avesso de todos os viajantes, isto é, que não pregues mentiras" (CMT, p. 27, grifo do autor). Em outro momento, após ter 
recebido uma quantia para custear a viagem, o sobrinho é tentado a não realizá-la e inventá-la, assim como fizeram tantos outros escritores ${ }^{8}$ :

\begin{abstract}
Assim que tive a certeza de que estava com seiscentos mil réis na algibeira, veio-me logo a ideia de partir para a corte, aboletar-me ali em algum hotel famoso, divertir-me um mês nos bailes, nos teatros e nos passeios, passar, enfim, vida regalada, e improvisar nas horas vagas duas mil mentiras, com que pudesse encher a Carteira de meu tio.

Esta pouca vergonha não teria nada de original, e não podia espantar a ninguém: alguns dos meus colegas viajantes, e principalmente os franceses, que são incomparáveis nesta, como em muitas outras espécies de charlatanismo, já têm feito o mesmo que eu estive quase não quase a praticar: uns sem sair do Pharoux já têm passeado por Minas, Goiás e Mato Grosso, e milagrosamente escapado de serem lambidos pelos bugres e pelas onças; outros, depois de devorar um lauto jantar, e de escorrupichar algumas garrafas do bordeaux e de champagne, juram ter no mesmo dia e à mesma hora estado a ponto de morrer de febre e de sede nos campos de São Paulo, onde os caipiras negam pão e água aos estrangeiros; estas inocentes mentiras tiram um imenso trabalho à gente, e é até um belo meio de apurar a imaginação: os tais viajantes franceses são pela maior parte homens de mão cheia! (CMT, p. 30, grifo do autor).
\end{abstract}

Assim, o narrador - e, por conseguinte, a sua própria narrativa - se considera distinto desses viajantes e seus relatos, uma vez que não se coaduna com a mentira como fundamento da escrita. Da mesma forma que a sua narrativa, o sobrinho não é “completamente digno do século em que viv[e]: porque ainda [lhe] resta um átomo de consciência" (CMT, p. 31). Com isso, Macedo pontua a distância entre A Carteira de Meu Tio e as narrativas de viagem importadas: o seu objetivo não é enganar o leitor, oferecendo-lhe os lugares-comuns das descrições eufóricas da paisagem nacional, mas conscientizá-lo para os problemas da realidade social e política brasileira.

Por outro lado, é necessário assinalarmos que a recusa do sobrinho de se identificar e de apontar a localização da fazenda de seu tio também é uma forma de mostrar que a obra se trata de uma alegoria, e não de um caso particular. O sobrinho não representa

\footnotetext{
${ }^{8}$ Lembramo-nos aqui da crítica feita por Pinheiro Chagas a Fernão Mendes Pinto e Alexandre Dumas (Cf. 1866, p. 33-34), referida por nós no subcapítulo anterior.
} 
determinado político - ou aspirante à política -, mas, se não todos, grande parte deles: é um personagem-tipo, representante de uma classe, a classe política. Como ele mesmo afirma, "sou neste ponto o eco de muitos estadistas do país" (CMT, p. 36).

Descrito como "impostor e atrevido" (Cf. CMT, p. 22), a inclinação do sobrinho para a carreira política veio da preguiça: "do mesmo modo que sucede a todos os vadios de certa classe, a primeira ideia que me sorria, tinha sido a política!” (CMT, p. 22). A partir de suas observações, o leitor tem acesso ao ponto de vista dos "grandes", ou seja, dos que estão no poder: "Eu digo as coisas como elas são: há só uma verdade neste mundo, é o $E u$; isto de pátria, filantropia, honra, dedicação, lealdade, tudo é peta, tudo é história, ficção, parvoíce; ou (para me exprimir no dialeto dos grandes homens) tudo é poesia” (CMT, p. 19, grifo do autor). Nesta sentença, o narrador mostra que os valores românticos - o amor à pátria, a filantropia, a honra, a dedicação e a lealdade - só são encontrados na ficção, na poesia, isto é, não são aplicados na vida real. Em outra passagem, o sobrinho conta como fez para se tornar um “doutor" e, assim, adquirir o status necessário para ser reconhecido na sociedade brasileira:

Aos vinte anos de minha idade parti para a Europa, a fim de completar os meus estudos (à custa de meu tio, já se sabe). Estudei com efeito muito em Paris, onde assentei a fateixa: oh! Sim, estudei muito! Passeei pelos boulevards; fui aos teatros; apaixonei-me loucamente por vinte grisettes; tive dez ou doze primeiros amores; por me faltar o tempo não pude ver uma só biblioteca; por me acordar sempre tarde nunca frequentei aula alguma; e no fim de cinco anos dei um pulo à Alemanha, arranjei uma carta de doutor (palavra de honra que ainda não tive a curiosidade de examinar em que espécie de ciência), e voltei para este nosso Brasil, apresentando-me a meu tio logo no primeiro instante com as mais irrecusáveis provas do meu aproveitamento, isto é, vestido no último rigor da moda, falando uma algaravia, que é metade francês e metade português, e ostentando sobretudo por cima do meu lábio superior um bigodinho insidioso, por baixo do meu lábio inferior uma pera fascinadora, e para complemento desses encantos, um charuto aromático preso e contínuo entre os lábios, perfumando a pera e o bigode. (CMT, p. 21, grifo do autor). 
Nesta passagem, Macedo denuncia o hábito pernicioso dos brasileiros de só valorizarem aquilo que vem de fora, principalmente da Europa, sem verificar se é ou não genuíno e de boa qualidade - como "a orquestra do nosso teatro italiano, que com seus cheios, fortes, e fortíssimos e arranjos oportunos encobre as desafinações e as misérias artísticas das cantarinas e cantores de cartello, que nos vêm da Europa ganhar dezenas e dezenas de contos de réis por ano" (CMT, p. 30, grifo do autor). Com isso, o narrador desvela o aspecto postiço - e ridículo - da imitação da cultura europeia feita pelos brasileiros, plasmada na indumentária do sobrinho - uma artificialidade que também ocorreria na imitação da literatura produzida no velho mundo.

Como discutimos anteriormente, a descrição do exotismo da paisagem brasileira foi um dos principais recursos utilizados pela literatura de viagens escrita por viajantes estrangeiros. Em A Carteira de Meu Tio, ao contrário, o narrador pouco se afasta geograficamente da fazenda do tio, pois o seu cavalo "anda mais devagar do que as obras da nação" (CMT, p. 23), e, portanto, pouco vê da paisagem nacional e menos ainda anota sobre ela. Aquilo que descreve, aliás, em muito se distingue da perspectiva eufórica típica das narrativas de viagem: "a estrada era cheia de sovacões, atoleiros e precipícios" (CMT, p. 34). Nas palavras de Juliana Maia de Queiroz,

o narrador de $A$ carteira de meu tio evidencia sua postura contrária àquela dos típicos viajantes estrangeiros que por aqui passaram no tempo do Brasil imperial e deixaram registrados em seus diários suas impressões sobre as regiões visitadas. Não se trata de uma viagem de reconhecimento e descrição da natureza local; muito pelo contrário, não há nenhuma referência geográfica dos locais por onde passam as personagens. (2011, p. 73).

Além disso, em vez da descrição de curiosidades da vida campesina e seus costumes, o que encontramos no romance são as mazelas sofridas pelo povo, deixadas por um 
governo corrupto e incompetente: estradas mal cuidadas, impostos descabidos, abusos de autoridade. Segundo reflete o sobrinho, ironicamente, ao passar num lamaçal,

Ficou [...] para mim demonstrado que o presidente da província não tinha amigo, nem compadre, a quem visitasse uma vez ou outra, ali por aqueles lugares: um passeio, ou viagem do presidente da província é, no meu entender, o que melhor esclarece a urgência do conserto de uma estrada: enquanto as tropas carregadas dos fazendeiros e lavradores se estropeiam no caminho, e algumas bestas morrem atoladas na lama, ainda se pode sofrer o mal; mas dar um solavanco a carruagem de S. Exa.!... misericórdia, ficava a pátria em perigo!... (CMT, p. 34).

Temos aqui, então, a denúncia de que os políticos somente trabalham em proveito próprio e dos seus conhecidos, crítica reforçada em outra passagem do romance. Nela, a pátria é definida de forma rebaixada, distante da perspectiva ufanista adotada pela literatura romântica:

A pátria é uma enorme e excelente garopa: os ministros de estado, a quem ela está confiada, e que sabem tudo muito, mas principalmente gramática e conta de repartir, dividem toda nação em um grupo, séquito e multidão: o grupo é formado por eles mesmos e por seus compadres, e se chama - nós -, o séquito um pouco mais numeroso se compõe dos seus afilhados, e se chama - vós -, e a multidão, que compreende uma coisa chamada oposição e o resto do povo, se denomina - eles -; ora, agora aqui vai a teoria do $E u$ : os ministros repartem a garopa em algumas postas grandes, e em muitas mais pequenas, e dizem eloquentemente: "as postas grandes são para nós, as mais pequenas são para vós" e finalmente jogam ao meio da rua as espinhas, que são para eles. O resultado é que todo o povo anda sempre engasgado com a pátria, enquanto o grupo e o séquito passam às mil maravilhas à custa dela! (CMT, p. 19-20, grifo do autor).

Assim sendo, de acordo com Süssekind, "neste caso a peregrinação pela própria terra é muito mais uma peregrinação crítica pela política imperial do que qualquer outra coisa [...]. O sobrinho-cronista praticamente não viaja, interpreta apenas a situação do país" (1990, p. 227-228, grifo da autora). A questão do favor como mediação das relações de poder no 
Brasil, por exemplo, tema analisado por Roberto Schwarz na obra de Machado de Assis, já encontra a sua crítica no romance macediano:

Pois deveras será necessário estudar nos livros dos homens, ou ainda mesmo no da experiência, para um moço de esperanças, como eu, ou qualquer outro tornar-se apto para ser deputado, presidente de província, ou ministro de estado?... Eu entendo que não. Nos bailes, nos teatros, nas visitas e nos cumprimentos é que se demonstram os futuros estadistas: vale mais uma carta de um compadre ou sócio de ministro, mais ainda a recomendação da Exma. Quarentona com quem dançamos, e passeamos no baile, do que um diploma da mais célebre academia, e as provas as mais evidentes de uma inteligência superior. O patronato é a placenta da sabedoria, e a medida do mérito: tomara eu ser afilhado de algum bom padrinho, que verão como fico imediatamente sábio, e até mesmo benemérito da pátria! (CMT, p. 23, grifo do autor).

Dessa forma, as reflexões do narrador procuram conscientizar o leitor para os problemas sociopolíticos do país, porém, não de forma pedagógico-doutrinária - como seria o esperado numa narrativa de viagem convencional -, mas como um contraexemplo, uma vez que o sobrinho é um mau caráter. Como explica Bianca Karam, “é o narrador parasita que reconhece e desnuda as falcatruas. E, se por isso poderíamos pensar, em princípio, em uma narrativa moral [...] estaríamos equivocados, afinal, ele é delator das mentiras de que também se serve para bem viver" (2006, p. 83). Por outro lado, temos a presença de um personagem que se contrapõe ao sobrinho-narrador: o compadre Paciência, que dialoga com ele durante grande parte da viagem. Enquanto o sobrinho representa o ponto de vista dos políticos corruptos, o compadre Paciência é a voz da sabedoria - pelo menos para Macedo, um defensor da monarquia liberal ${ }^{9}$.

A crítica do compadre Paciência é dirigida explicitamente aos presidentes das províncias, uma vez que “os tais presidentes são politicões, ou criaturas dos politicões” $(C M T$, p. 37), que utilizam a força policial e o voto de cabresto para se perpetuarem no poder e

\footnotetext{
${ }^{9}$ Como explicamos anteriormente, Macedo era adepto do Partido Liberal, tendo sido inclusive deputado por esse partido. Por outro lado, a sua relação com a família real o tornava também um defensor da monarquia.
} 
indicar os deputados que lhes são favoráveis: “o povo vota sempre em quem governa, porque sabe que quando assim o não quer fazer, fica reduzido a cão leproso, que apanha e não tem quem lhe acuda" (CMT, p. 37). Através de seu discurso, encontramos a defesa de um sistema político representativo, no qual não haveria lugar para o patronato, a corrupção e o abuso de poder:

Com eleições livres os ministros tratam de andar direito, porque sabem que têm de dar contas às câmaras; os deputados procuram zelar os interesses públicos, porque sabem que têm de dar contas ao povo; e o povo quase sempre vota bem, porque sabe que votando escolhe o juiz para sua demanda. (CMT, p. 37-38).

No fim do romance, todavia, o sobrinho conta que o compadre Paciência acaba sendo preso por perturbar a ordem:

Os tais senhores liberais e preconizadores do progresso são verdadeiros condutores de peste, e devem por isso mesmo ser recolhidos à cadeia, espécies de lazaretos muito convenientes para se guardarem em quarentena os patriotas.

Ainda bem que a polícia entende a coisa assim e prende e solta a quem quer, sem dar satisfação a ninguém; se não fosse a polícia teria o Brasil dado à costa nos cachopos da anarquia! (CMT, p. 126).

Com isso, o narrador apresenta uma melancólica derrota dos ideais liberais, comemorada por aqueles que estão no poder. Sob esse ponto de vista, quem vence neste mundo são os sobrinhos, isto é, os egoístas e corruptos, o que nos faz questionar o suposto intuito didático da narrativa. Em outra passagem, através da voz do sobrinho-narrador - que conclui que não vale a pena ser honrado -, o autor já havia refletido que os bons - sendo pobres - habitualmente se dão mal na sociedade brasileira, revelando a sua falta de esperança: 
Aí temos um homem pobre, e honrado em toda a extensão da palavra! Segue à risca as leis de Deus, e obedece à dos homens [...]; trabalha noite e dia para dar pão a seus filhos [...]; em uma palavra, cumpre todos os deveres de um cristão, que tem fé, e todos os deveres de um cidadão, que ama a pátria. Mas... é pobre! pobre nasceu, vive pobre, e há de pobre acabar [...].

Se ele espirra, nem lhe dizem - dominus tecum!

Quando passa na rua, ninguém lhe cede a calçada, ainda que o vejam manquejando, porque é um farroupilha de jaqueta; e o carro do rico [...] atira-lhe terra nos olhos, e lama no nariz!

Se vai falar a um ministro, nunca o acha em casa, e o correio o despede na escada [...].

Quando requer o seu direito, torcem-lhe o nariz, se protesta e recalcitra, mandam-no para a cadeia.

Se serviu algum emprego, em que facilmente pudesse abusar, e assim fazer dinheiro, e preferiu ficar na sua honesta pobreza, e passa depois na rua com a casaca mostrando os cordões, não dizem: lá vai um homem de bem; apontam-no com o dedo dizendo em tom de mofa ou de piedade: lá vai um tolo que não se soube aproveitar [...].

Se não acaba em um hospital, morre em casa em uma esteira velha.

E quando morre, não deixa um amigo que lhe reze por alma, e acaba ao menos com esta certeza consoladora: não tem depois de morto poetas de certa ordem que lhe façam versos. (CMT, p. 45-46, grifo do autor).

Apesar de concentrar-se na crítica à sociedade brasileira e seus políticos ${ }^{10}$,

Macedo não deixa de inserir comentários cômicos que menosprezam a literatura em voga,

como no trecho anterior, em que - num momento de autoironia - zomba dos poetas que prestam homenagens a falecidos ilustres ${ }^{11}$. Além disso, o autor também deprecia as próprias reflexões feitas no romance, como na passagem em que o sobrinho afirma ter sido inspirado

\footnotetext{
${ }^{10}$ Optamos aqui por não relacionar a crítica que Macedo faz, em A Carteira de Meu Tio, a aspectos específicos da política imperial brasileira porque tais questões já foram suficientemente trabalhadas em outras pesquisas, tais como a Dissertação de Mestrado de Priscilla Rampin de Andrade, apresentada em 2011 à Universidade de São Paulo, intitulada Um Cronista na Tribuna: Joaquim Manuel de Macedo, imprensa e política na consolidação do Estado-nacional brasileiro; a Dissertação de Mestrado de Nelson Carneiro Júnior, intitulada As Imagens da Cultura Política Brasileira em A Carteira de Meu Tio de Joaquim Manuel de Macedo, defendida na Universidade Federal de Goiás, em 2008; e a Tese de Doutorado de Juliana Maia de Queiroz, defendida em 2011 na Universidade Estadual de Campinas, intitulada As Múltiplas Facetas de Joaquim Manuel de Macedo: um estudo de A Carteira de Meu Tio, Memórias do Sobrinho de Meu Tio e A Luneta Mágica. Além disso, acreditamos que o romance estende a sua crítica não somente a problemas exclusivos do Segundo Reinado, mas a questões que já faziam parte da política nacional há muito tempo, como o narrador sugere em alguns momentos - e, a nosso ver, a questões que ainda hoje não foram resolvidas. Nas palavras de Leandro Thomaz de Almeida, “[...] chama a atenção que um livro que já tem seus 155 anos [agora são 158 anos], ofereça tantos pontos de contato com a sociedade brasileira atual. Cabe ao leitor estabelecer estes pontos, o que não será tarefa tão difícil. Ainda hoje lemos e ouvimos frequentemente que as leis do Brasil são muito boas, o problema está em não saírem do papel. Assim como não temos que nos esforçar muito para encontrar depoimentos que critiquem a morosidade da justiça, a pronta punição dos pequenos crimes enquanto os grandes crimes ficam impunes, a frequente mudança de partido por parte dos políticos...” (2010a, p. 26).
}

${ }^{11}$ Macedo também fazia as suas homenagens, dentre as quais ficou célebre o discurso que fez no enterro de Álvares de Azevedo (Cf. SERRA, 2004, p. 303). 
pelo lamaçal: “Atolei-me, sim, meu caro; dou porém parabéns à minha fortuna; porque descobri neste lamarão um grande pensamento político!” (CMT, p. 35). Dessa forma, ao desdenhar ironicamente das suas próprias meditações - feitas por um pseudonarrador-viajante -, o romance acaba por rebaixar as reflexões filosóficas usualmente encontradas nas narrativas de viagem, que eram muitas vezes patrocinadas por órgãos públicos:

[...] eu sou um filósofo de arromba, e não posso estar um só momento sem refletir sobre as coisas deste, e até mesmo do outro mundo: pareço-me neste ponto muito com certos sujeitos, que empregam todo o seu tempo, e sacrificam toda a sua vida tratando de fazer o bem da pátria; a única diferença que há entre mim e eles, é que o tesouro público não me paga as minhas filosofias. (CMT, p. 44, grifo do autor).

Por fim, é inevitável que retomemos o qualificativo utilizado por Ferdinand Wolf para definir A Carteira de Meu Tio: "viagem fantástica". Numa das passagens do romance, o fantástico $^{12}$ de fato toma conta da narrativa, na descrição de um sonho do sobrinho, no qual ele vê a personificação dos vícios. O Engodo, a Agiotagem, a Imoralidade, a Hipocrisia, o Escândalo, a Corrupção, o Egoísmo, a Intriga, a Traição e a Covardia estariam caminhando num desfile, entoando um hino que definiria a sociedade brasileira:

\author{
[...] Viva o dinheiro! \\ Fora o ideal! \\ Viva o progresso \\ Material!... \\ A vida que nós passamos \\ É contra a Constituição, \\ Mas não faz mal é milagre \\ Da santa conciliação. [...] \\ Isto de pátria e virtude \\ Honra e glória é só - poesia \\ Poder, dinheiro et cetera \\ É que tem gosto e valia. [...]
}

\footnotetext{
${ }^{12} \mathrm{Na}$ acepção de Tzvetan Todorov, tratar-se-ia, mais especificamente, de um trecho alegórico, e não fantástico. Entretanto, optamos por não fazer aqui a distinção dos termos, seguindo a definição encontrada em Wolf.
} 
Nosso altar é a algibeira,

Nossos deuses prata e ouro,

Nossa oração - venha a nós,

e o nosso Céu o tesouro. [...] (CMT, p. 93, grifo do autor).

A política de conciliação $^{13}$ é vista, aqui, como a grande responsável pela manutenção da situação deplorável da política nacional, cujos agentes corruptos só buscavam atender aos seus próprios interesses, visando ao enriquecimento à custa da nação. Como o sobrinho ilustra em outro momento - quando, ao discordar com um estalajadeiro, acaba ficando sem o jantar -, a conciliação elimina a oposição, oferecendo benesses para todos, em detrimento dos interesses do povo: "Não será muito melhor conciliar-me com o sr. Constante, declarar-me francamente ministerial, e receber em troco da minha metamorfose política algum petisco, que me venha beatificar o estômago?...”(CMT, p. 75-76, grifo do autor).

O sonho, por outro lado, é interrompido com o ronco do compadre Paciência, acabando por quebrar a atmosfera fantasmagórica de forma cômica, enfraquecendo a impressão que poderia causar no leitor, chamando-o para a realidade: "Ouvi rebentar um trovão espantoso... Dei um pulo da cama assombrado... Diabo! O trovão que eu acabava de ouvir era simplesmente um ronco do meu compadre Paciência, que dormia como um porco!" (CMT, p. 94). Assim, mesmo numa passagem primordialmente fantástica, Macedo impede o arrebatamento do leitor, interrompendo o suscitar das emoções, forçando o leitor a se ater à realidade, fazendo-o refletir sobre ela.

Ao comparar A Carteira de Meu Tio com Uma Viagem Sentimental (1768), de Laurence Sterne, e Viagem ao Redor do Meu Quarto (1794), de Xavier de Maistre, autores que também criticaram as narrativas de viagem e com os quais Macedo parece ter dialogado, Bianca Karam defende que "a ironia presente nos três relatos de viagem é marcada especialmente por uma crítica aos registros daqueles que se autointitulam grandes viajantes,

\footnotetext{
${ }^{13}$ A política de conciliação consistiu na divisão dos cargos executivos entre o partido Liberal e o Conservador, como forma de abrandar as disputas políticas e manter o poder central nas mãos de D. Pedro II.
} 
mas, na verdade, nada observam sobre o lugar visitado, descrevendo fatos e dados superficiais e irrelevantes, ou sequer visitaram o lugar sobre o qual descrevem" (2006, p. 109). Todavia, a pesquisadora nota que

Se tanto em Sterne como em Maistre a reflexão sobre viagens é caracterizada pela busca da superação da superficialidade turística; em Macedo o foco principal deixa de ser a viagem para ser a manutenção do bem-estar individual, uma vez que o sobrinho viaja porque lhe convém, sem que necessariamente compartilhasse do empenho reflexivo de seu tio. Dessa maneira, suas análises profundas surgem mais como consequência das situações adversas que se opõem à manutenção da religião do Eu do que pelo desejo do sobrinho de modificar a realidade do país do século XIX. (2006, p. 109).

Como Karam explica, “enquanto os narradores de Sterne e Maistre buscam a sabedoria - um observando terras distantes, outro em seu mundo interior - o sobrinho apenas cumpre uma tarefa em busca de benefícios" (2006, p. 114). Em suma, o sobrinho não vê a viagem como forma de aprendizado e, portanto, não procura o conhecimento através dela: o propósito de sua viagem é, assim, totalmente prosaico - apenas obedece ao tio para obter em troca o seu dinheiro e a sua influência para seguir a carreira política -, distanciando-se dos nobres propósitos dos outros viajantes.

Dessa forma, como pudemos perceber a partir dos excertos aqui analisados, o romance macediano não possui as principais características encontradas nas narrativas de viagem consumidas no século XIX: não é uma literatura "amena", voltada unicamente ao entretenimento; não trata de aventuras; não descreve a nação e sua paisagem sob uma perspectiva eufórica; não procura suscitar a emoção do leitor; e não possui um intuito didático, uma vez que não traz reflexões filosóficas de maneira pedagógico-doutrinária. Ao contrário, através de um narrador nada exemplar, A Carteira de Meu Tio dialoga com as convenções da literatura de viagens, frustrando as expectativas do leitor, utilizando-se de sua temática para empreender a sua crítica à política e à sociedade brasileiras. 


\section{Lunetas mágicas e esqueletos: releituras da narrativa fantástica}

De controversa definição, o subgênero fantástico já suscitou inúmeros estudos, impulsionados pela teorização de Tzvetan Todorov. Remo Ceserani, por exemplo, critica a tendência dos "repertórios bibliográficos mais difundidos, os dicionários biográficos dos escritores praticantes dos vários gêneros e subgêneros ligados ao fantástico, os catálogos das bibliotecas, os bancos de dados das instituições internacionais, as coleções das editoras" (2006, p. 10) de “fazer um único caldeirão no qual o fantástico romântico de Todorov se mistura com uma grande quantidade de outros produtos literários, até mesmo da literatura mais 'baixa' e de consumo, perdendo cada uma a sua identidade" (2006, p. 10). Sabemos que Todorov definiu o fantástico de maneira bastante específica, distinguindo-o de outros subgêneros, como o estranho, o maravilhoso e a alegoria. Entretanto, tal diferenciação foi feita a posteriori, uma vez que, durante o século XIX, os escritores, críticos e anunciantes colocavam, de fato, tudo em "um único caldeirão".

Em A Geração Nova, por exemplo, publicada em 1886, Sampaio Bruno usa tanto o termo "fantástico" quanto o termo "maravilhoso" ao se referir à obra de E. T. A. Hoffmann e Edgar Allan Poe. Como nos referimos no capítulo anterior, o romance macediano $A$ Carteira de Meu Tio é mencionado em O Brasil Literário (1863), de Ferdinand Wolf, como uma "viagem fantástica", apesar de nele estarem presentes elementos alegóricos. Por isso, neste trabalho optamos - apoiados justamente pelos "repertórios bibliográficos", “dicionários biográficos", "catálogos das bibliotecas", "bancos de dados das instituições internacionais" e "coleções das editoras", acima referidos - por utilizar o termo "fantástico" de forma mais abrangente. Para nós, em suma, como tão bem sintetizou Maria Leonor Machado de Sousa, “o 
fantástico na literatura [...] é a perturbação do mundo quotidiano pela introdução de elementos extraordinários" (s/d, p. 468).

Uma das mais importantes estudiosas do fantástico em Portugal, Leonor de Sousa se concentrou no estudo da vertente que mais se popularizou no século XIX português, a "literatura negra" (do francês roman noir), cuja origem estaria no romance gótico inglês. Segundo a pesquisadora, o romance gótico, “criação do século XVIII”, “é essencialmente um romance sentimental, em cuja intriga de amor intervêm o sobrenatural e o misterioso, geralmente ao serviço de potências maléficas, mas que não conseguem destruir os heróis, assistidos pela justiça imanente que protege a virtude" (1979, p. 7). De acordo com ela, “a escola gótica procurava excitar terror (pelo manobrar do misterioso e do sobrenatural e pela alimentação constante da expectativa - suspense) e compaixão (pelas desgraças da heroína, modelo de virtude e abnegação)" (1979, p. 7, grifo da autora).

Como explica Sandra Vasconcelos, com escritores como Horace Walpole e Clara Reeve "abria-se a temporada de caça ao efeito dramático, ao sensacional, ao estranho, ao maravilhoso" (2007, p. 114). Nesses romancistas, a história sentimental seria "revestida de um invólucro gótico no qual a arquitetura exercia papel fundamental, repunha em cenas situações e circunstâncias cujo objetivo maior era criar suspense e provocar sensações de temor e surpresa no leitor" (2007, p. 115). As características do subgênero já estariam expostas no prefácio da primeira edição de O Castelo de Otranto (1764), de Walpole, traduzido por Vasconcelos:

Se se desculpa essa aparência do miraculoso, o leitor não encontrará mais nada indigno de sua leitura atenta. Admita-se a possibilidade dos fatos e todos os atores se comportam como as pessoas o fariam em sua situação. Não há linguagem bombástica, símiles, retardadores, digressões ou descrições desnecessárias. Tudo leva diretamente à catástrofe. Nunca a atenção do leitor é relaxada. [...] O terror, principal motor do autor, impede que a história perca o ritmo e é com tal frequência contrastado com a compaixão que a mente se mantém numa constante vicissitude de paixões interessantes. (Apud VASCONCELOS, 2007, p. 405, grifo do autor). 
Neste excerto, Walpole mostra que, para provocar o terror - principal objetivo do romance gótico -, é necessário concentrar-se na ação, mantendo a tensão do leitor, levando-a diretamente à catástrofe, sem interrompê-la com digressões. Além disso, é preciso persuadir o leitor a aceitar o sobrenatural, através do revestimento da ação, de modo sério e convincente, com a "aparência do miraculoso". Nas palavras de Filipe Furtado, "nas narrativas fantásticas, espera-se do ator-testemunha que, perante uma ocorrência metaempírica, fique aterrado ou, no mínimo, perplexo - nunca divertido" (1980, p. 52). Para o teórico, "se, por absurdo, essa personagem graceja com o monstro em estilo coloquial, semelhante atitude (possível e, até, plausível segundo o senso comum) perde toda a consistência à luz das regras do gênero" $\left(1980\right.$, p. 52) ${ }^{1}$.

Ana Maria dos Santos Marques, por sua vez, afirma que o cenário da ação, "um ambiente arcaico, com um caráter sufocante" (2010, p. 60), “composto por castelos medievais semiarruinados, torres abandonadas, ou conventos sombrios, que possuem longos e labirínticos corredores e escadarias, passagens secretas e portas falsas, subterrâneos e masmorras" (2010, p. 60), contribuía para induzir o terror, incitado pelos "mais horríveis crimes, perpetrados na mais completa escuridão ou apenas à luz mortiça e lúgubre de velas ou candeias" (2010, p. 60). De acordo com a pesquisadora, o cenário, juntamente com o recuo temporal - usualmente na Idade Média - serviam para "afastar esse mundo de artifício da realidade imediata do leitor e, assim, permitir a sua total fruição” (2010, p. 63).

Segundo Marques, "este universo altamente convencionalizado é rapidamente assimilado e reproduzido" (2010, p. 67), como se pode verificar num excerto - citado por Alain Montandon e relembrado por ela - do jornal Le Spectateur du Nord (1798), publicado alguns anos depois de Os Mistérios de Udolpho (1794), de Ann Radcliffe. Tratar-se-ia de uma irônica "'receita” para a elaboração de romances góticos” (2010, p. 67):

\footnotetext{
${ }^{1}$ Sabemos que havia alguns escritores, como E. T. A. Hoffmann, que também inseriam o humor em suas obras fantásticas. Entretanto, essa não é a regra verificada no subgênero, que, em sua maioria, pretendia suscitar o terror no leitor através da tensão constante da narrativa.
} 
Um velho castelo em ruínas; um longo corredor com muitas portas, muitas das quais devem estar escondidas; três cadáveres ainda ensanguentados; três esqueletos bem encaixotados; uma velha enforcada, com algumas facadas na garganta; ladrões e bandidos à profusão; uma dose suficiente de sussurros, gemidos abafados e acidentes horríveis. Todos esses ingredientes bem misturados e divididos em três partes ou volumes dão uma excelente mistura $^{2}$.

Maria Leonor de Sousa esclarece que "a pouco e pouco, foi-se perdendo o caráter medieval, que passou a reduzir-se ao cenário de castelos assombrados ou abadias em ruínas para onde os criminosos levavam as suas vítimas. [...] O termo 'gótico' perdeu assim a sua razão de ser, tendo-se generalizado em seu lugar o termo 'negro', de origem francesa” (1979, p. 7). A estudiosa afirma que os romances de Ann Radcliffe começam a aparecer em Portugal na década de 1830, e "até 1850 surgem em catadupa Ducray-Duminil, Arlincourt e Victor Hugo. Para o fim do período [...], são publicadas também umas após outras as obras dos autores pseudorrealistas interessados pelo negro contemporâneo, Eugène Sue e Frédéric Soulié” (1979, p. 16, grifo da autora).

Juliana Maia de Queiroz, por sua vez, aponta também a leitura de outros autores no Brasil, como mostra um dos catálogos da Livraria Garnier, da década de 1870, que possui "uma espécie de coletânea, intitulada 'Cousas extraordinárias: O escaravelho de ouro, A febre dos diamantes, Amor nas trevas, Ingleses e Chineses"", composta de textos de "Poe, Hoffmann, Scribe, Méry" (2011, p. 142). Além disso, não podemos nos esquecer da popularidade de Alexandre Dumas, cujo Mil e Um Fantasmas (1849-1850) foi alvo do elogio de J. M. de Andrade Ferreira, em artigo na Revista Contemporânea de Portugal e Brasil, publicado em 1859:

\footnotetext{
${ }^{2}$ Tradução nossa do original: "Un vieux château en ruine; un long corridor avec beaucoup de portes, dont plusieurs doivent être cachées; trois cadavres encore tout sanglants; trois squelettes bien emballés; une vieille femme pendue, avec quelques coups de poignard dans la gorge; des voleurs et bandits à discrétion; une dose suffisante de chuchotements, de gémissements étouffés et d'horribles fracas. Tous ces ingrédients bien mêlés et partagés en trois portions ou volumes donnent une excellente mixtion [...]." (Apud MONTANDON, 1999, p. 454).
} 
Há certo gênero de livros cuja leitura parece destinada para ser feita nessas estiradas noites de inverno, em que o frio e a geada nos convidam a buscar o conchego doméstico, assentados com expansiva e íntima familiaridade, em círculo apertado, ao calor de um bom brasido. Alexandre Dumas escreveu um destes livros, a que pôs o título de Mil e um fantasmas.

O título deste livro inculca, à primeira vista, um supremo esforço do gênio lúgubre e fantástico de Anna Radcliff, capaz de pôr os cabelos em pé a quatro velhas de lareira, e fazer tranzir de pavor as crianças mais afeitas a contos de bruxas e duendes.

E todavia não é assim.

Antes de correr essas primeiras páginas, uma certa preocupação, aquela preocupação misteriosa que suscita tudo que tenha relação com os que já não são deste mundo, nos obscurece o ânimo de nuvens pesadas e melancólicas, através das quais julgamos ver espectros sinistros, revoando-lhes em torno todo esse cortejo de espíritos maus, gnomos, vampiros, larvas, brocolacos, abejões, ogres, trasgos, de que a fantasia dos povos cristãos povoa os seus criptos e cemitérios: mas folheado o primeiro capítulo, a imaginação começa a desanuviar-se destas ideias pavorosas, e a curiosidade a seguir, a prenderse, a identificar-se às cenas que o engenhoso romancista nos põe diante dos olhos [...]. Nas histórias de espectros e duendes há sempre uma atração, um poder simpático que arrasta a curiosidade, ainda do homem esclarecido. E a razão é porque estas ideias supersticiosas não estão no livro, não são criações fantásticas do poeta, estão no ânimo do leitor, esvoaçam por toda a atmosfera que ele respira, existem nas imagens e crenças que rodeiam logo no berço, residem nos hábitos, no pensar, na credulidade do país que viu nascer [...]. O escritor, neste caso, copia mais do que inventa; serve-se antes da memória do que da imaginação. (1859, p. 513-514).

Neste ensaio, o crítico enaltece a obra de Dumas pelo fato de o autor francês desviar-se de algumas das convenções da literatura fantástica, produzindo um enredo cativante e verossímil. Por outro lado, é possível depreender deste trecho as expectativas de leitura que o público oitocentista tinha ao se deparar com uma narrativa fantástica: o esperado era encontrar histórias lúgubres e terríficas com criaturas lendárias ou sobrenaturais, as quais, por serem baseadas nas superstições populares, contribuiriam para incitar o medo no leitor.

Em Portugal, de acordo com Maria Leonor de Sousa, tais convenções começaram a ser utilizadas pelos escritores a partir da década de 1840, em contos publicados em $O$ Mosaico e $O$ Correio das Damas, nos quais é possível encontrar "um dos traços macabros de maiores repercussões na novelística original portuguesa do século XIX": "o desenterramento de cadáveres" (1979, p. 21). A pesquisadora também cita a relevância de A Noite do Castelo 
(1836), de António Feliciano de Castilho, e O Castelo do Lago (1841), de José Maria Teixeira de Queiroz, que se inserem "na tradição da balada”, com "elementos do 'terror gótico' cenário, traições, vinganças, espectros” (1979, p. 45), e das obras de Álvaro do Carvalhal, que "não desdenhou qualquer elemento da literatura de terror: o manuscrito (Os Canibais), o espectro (O Punhal de Rosaura, A Febre do Jogo), o artifício fatal do embuçado (Honra Antiga), a obsessão lúgubre (J. Moreno), o erotismo doentio (A Vestal)” (1979, p. 61).

Já no Brasil, segundo Cilaine Alves Cunha, "a precursora na adaptação da narrativa do horror, ambientada em lugares sombrios com exaustivos episódios de sangue e depravação, desencadeados pelo herói celerado, foi Noite na taverna" (2004, p. 120), de Álvares de Azevedo: "redigida provavelmente entre 1850 e 1852 e publicada postumamente em 1855, alcançou grande sucesso de público e uma forte repercussão nos círculos literários da época" (2004, p. 120). Além deste volume de contos, podemos também apontar a peça Macário (1855), do mesmo autor, que traz a figura fantástica de Satã, personagem de inspiração gótica.

Tendo-se em vista as questões levantadas aqui, buscamos pontuar as estratégias utilizadas pelos escritores de histórias fantásticas para suscitar o suspense e o terror no público oitocentista, que apreciava e consumia os elementos macabros e sobrenaturais. A seguir, analisaremos a maneira como Camilo e Macedo se valeram da popularidade da literatura fantástica, revestindo as suas obras de aspectos que evocam tais narrativas, de forma a chamar a atenção do leitor, mas que acabam, por fim, quebrando as expectativas de leitura, propondo, em seu lugar, a reflexão sobre a sociedade e o próprio fazer literário. 


\subsection{O Esqueleto, uma história que faz arrepiar os cabelos?}

O Esqueleto: romance foi publicado por Camilo Castelo Branco originalmente em folhetins no decurso de 1864 , tendo sido editado em livro no ano seguinte, em 1865 (Cf. CABRAL, Alexandre, 1988, p. 314). Não foi uma das obras de maior sucesso do autor; entretanto, se durante o século XIX teve duas edições, na década de 1920 foi lançada a sua sexta edição (Cf. MARQUES, H., 1925, p. 197). O seu chamativo título sugeriria tratar-se de um típico exemplar da literatura negra: o esqueleto poderia ser uma aparição sobrenatural ou um elemento macabro que conduziria o suspense na diegese com o intuito de aterrorizar os leitores. Contudo, ao longo da leitura do romance, percebemos que ele praticamente nada tem de terrífico - e o tal esqueleto, de fato, só aparece no antepenúltimo capítulo.

O enredo da obra remete ao romance sentimental, no qual a literatura gótica também se baseava: trata-se de uma história de amores e traições, que acaba de maneira trágica. O protagonista é Nicolau de Mesquita, um homem de 40 anos que vivia amancebado com Margarida Froment - uma francesa que abandonou o marido -, e que resolve regenerarse se casando com Beatriz, uma morgada de dezesseis anos, filha de seu primo. Nicolau, contudo, volta a relacionar-se com Margarida, e Beatriz acaba traindo o marido com seu primo Rafael Garção, um antigo namorado, que, no fim da história, é assassinado; a moça, por sua vez, acaba morrendo histérica, e Mesquita vive infeliz e vem a falecer muitos anos depois, também de um acesso nervoso. O que poderia ser visto como uma imitação de romance gótico, de cunho sentimental e intuito moralizante, com o elogio à virtude, é colocado em questão logo no prefácio por Camilo:

Enquanto a influência do romance nos costumes, estou mais que muito desconfiado de que o romance não morigera nem desmoraliza. 
Porém, admitida a ponderação que lhe alvidram os exortadores dos pais de família, não sei decidir como se há de escrever o romance fautor da sã moral. São dois os expedientes: levar os personagens viciosos ao despenhadeiro; ou criar anjos num paraíso sem serpente.

$\mathrm{Na}$ primeira espécie, mostra-se a luta de virtude e crime; natural e concludentemente triunfa a virtude. É o costume, com sacrifício, às vezes, da verossimilhança.

$\mathrm{Na}$ segunda forma de romancear, a virtude recebe as ovações sem batalha [...]. $\left(E^{3}\right.$, p. 1165).

Neste prefácio, o autor simula a defesa da primeira espécie de romance - haja vista que, obviamente, $O$ Esqueleto não trata de "anjos num paraíso sem serpente" -, reproduzindo o discurso dos romancistas da época, que, para justificarem as histórias de adultérios, pretendiam "fazer da ficção um instrumento de edificação moral" (Cf. VASCONCELOS, 2002a, p. 47), com a punição dos vícios e o elogio à virtude. Entretanto, Camilo sugere não acreditar no intuito didático do romance, que, para ele, "não morigera nem desmoraliza"; além disso, o triunfo da virtude, apesar de ser costume nos romances, não seria verossímil, uma vez que não aconteceria na vida real. Em $O$ Esqueleto, ao contrário, não somente a virtude não triunfa como também questionamos se ela de fato existe nos personagens.

O protagonista, primeiramente, está longe de ter um caráter honrado, uma vez que o narrador não afirma que ele teria sido ingenuamente seduzido por Margarida: "Nicolau de Mesquita amara a mulher do amigo [...]. Amara até ao absoluto desprezo de si mesmo. Seguira-a de Lião à Bélgica. E daqui se fugira com ela para Portugal, enquanto o marido fora a Paris pressurosamente a cuidar em negócios urgentes de sua indústria” ( $E$, p. 1169). A sua regeneração, por sua vez, é vista com ironia pelo narrador: “É certo que Nicolau de Mesquita estava enfastiado, arrependido, e devorado de ânsias de liberdade para retemperar o coração em amores novos. Pensava nas delícias de uma vida honesta; falsa virtude, que vem sempre

\footnotetext{
${ }^{3}$ Ao longo deste trabalho adotaremos a sigla $E$ sempre que citarmos o romance $O$ Esqueleto, de Camilo Castelo Branco. As citações são retiradas do volume IV das Obras Completas (1985).
} 
com o enojo da mulher, que a sociedade honesta repele” ( $E$, p. 1169, grifo nosso). Após abandonar Margarida para casar-se com Beatriz, Nicolau volta a procurar a amante, assim que descobre que ela estava vivendo feliz com outro homem, e decide reconquistá-la. Anos depois de abandoná-la novamente e encontrá-la na miséria, a francesa o culpa pela sua condição: "Reduziu-me a isto, Senhor Mesquita [...]. Eu tinha então vinte anos, vinte mil libras para gastar cada ano, e o respeito do mundo, o amor de meu marido [...]” (E, p. 1344).

Margarida, assim, apesar de claramente calcada na Marguerite Gautier, de $A$ Dama das Camélias (1848), de Alexandre Dumas Filho - francesa, apreciadora do luxo, desprezada pela sociedade por viver amasiada -, não é vista pelo narrador como uma mulher fatal, "ao serviço de potências maléficas" (Cf. SOUSA, M., 1979, p. 7), que teria tentado a suposta virtude do herói, como o comumente encontrado no romance gótico. Anos depois, a personagem é retratada mal vestida, na pobreza; todavia, não se trata, aqui, da típica expiação da mulher adúltera, mas da mais prosaica velhice: “Como descera até ali Margarida Froment? Uma palavra o diz: envelhecera" ( $E$, p. 1344). No final do romance, ela também não é punida: recebe uma herança da mãe falecida, doa metade ao marido, que empobrecera, e se regenera perante a sociedade: "Margarida, se fosse solteira, podia escolher bons casamentos. Dizia-se em Lião que ela era os melhores quarenta anos e as mais belas ruínas que ainda tinham visto os olhos dos seus pretensores, ofuscados pela prefulgência de duzentos mil francos" ( $E$, p. 1346). Assim, a personagem passa a ser bem vista pela hipócrita sociedade oitocentista, para a qual o dinheiro tudo reabilita.

Beatriz, por sua vez, apesar de descrita com os lugares-comuns da heroína romântica - "rosto e candura do Céu. Alegria de borboleta na Primavera entre as alvíssimas flores do espinheiro" (E, p. 1174) -, não é uma simples vítima de um sedutor D. Juan. Para começar, ela se casa com Nicolau mesmo estando apaixonada por Rafael, apesar de não ter sido forçada pelo pai: “- Gostas do primo Nicolau? Sê sincera, minha filha. [...] Se ele 
quisesse ser teu marido, aceitarias de boa vontade? [...] Eu não quero, nem deixo de querer. Consulto a tua vontade" (E, p. 1176). Nas irônicas explicações apresentadas pelo narrador, não vemos atitudes esperadas numa personagem que deveria ser um modelo de virtude:

\begin{abstract}
Alguém conjecturou que Beatriz acedera casar-se com o tio por despique do primo [que, mulherengo, não queria se casar com ela]; várias senhoras, no propósito de desdourá-la, afirmavam que ela optara pelo mais rico, sem levar em conta a diferença das idades, e os dissabores futuros [...]. A verdade, porém, das rompidas inteligências da menina e de Rafael já está dita: fora um brincar da borboleta com uma flor de madressilva; mais lirismo não tem anacreôntica nenhuma, se a anacreôntica for das mais honestas. ( $E$, p. 11971198).
\end{abstract}

Ao caracterizar Beatriz como uma moça tola e fútil, que aceitou se casar com um homem mais velho não por amá-lo nem por imposição do pai, mas simplesmente pelo dinheiro ou para se vingar do antigo namorado, o narrador acaba por não promover a identificação com a heroína, não movendo a compaixão dos leitores para com os seus dissabores. A forma como inicia o seu relacionamento com Rafael, aliás, não é descrita: fica parecendo ao leitor que a moça não fora seduzida pelo primo, mas que o adultério teria ocorrido quase que naturalmente.

Já Rafael é um típico herói byroniano, “[...] o mais galhardo e galã rapaz daquelas terras. Tinha pecados grandes, que os invejosos das suas proezas desejariam esconder, se pudessem. A humanidade, sua conhecida, dividira-se em dois bandos: os homens contra, as mulheres por ele" (E, p. 1197). Entretanto, ao ridicularizar a sua "[...] leitura de Clarisse Harlowe, da Nova Heloísa, do D. João, e outros modelos de algozes de corações” (E, p. 1198), o narrador mostra o quanto as suas atitudes teriam de artificial: "Mandou comprar os últimos romances franceses, e saboreou as horas na leitura e na meditação, com intervalos de espionagem [à janela de Beatriz]” (E, p. 1269). A sua morte, contudo, não tem nada de romanesco, apesar de os localistas, anos depois, terem-na atribuído aos ciúmes de Nicolau. 
Quando pretendia terminar o namoro com Beatriz - pois iria se casar com uma morgada mais rica -, Rafael vai ao encontro da moça e se esconde num aqueduto, por causa dos criados que estavam andando no quintal, vigiando as "desordens da romaria" (Cf. E, p. 1319). A prosaica cena de seu assassinato merece aqui ser reproduzida:

Os criados pararam ainda, conversando com os seus companheiros sobre a batalha da tarde. Dizia um deles:

- O que eu tenho pena é de levar esta bala para casa na clavina! [...]

- Querem vocês que nós demos a última descarga? [...]

Quando chegaram a pouca distância da mina, em que Rafael se escondera, disse um:

- Se vocês querem ver o que é berrar uma clavina, vamos estoirá-las dentro da mina. Isso faz aí um trovão, que nem peça de artilharia. [...]

E desfecharam os quatro bacamartes contra a boca da mina.

Rafael Garção, como empurrado pelas duas balas que lhe entraram no peito, recuou alguns passos, e caiu, de borco, e os braços cruzados entre o peito e a terra. (E, p. 1320-1321).

Dois dias após a morte histérica de Beatriz - ao se deparar com o cadáver do amante -, o aqueduto fora fechado, e o paradeiro de Rafael ficara desconhecido, conforme uma notícia "publicada no jornal portuense $O$ Nacional” (Cf. E, p. 1338). A gazeta conta que, quatro anos depois, Mesquita mandara "desempedrar" a porta do aqueduto, e seus operários "encontraram a quinze passos distantes da abertura da mina um esqueleto" ( $E$, p. 1339). Nesse momento, o narrador apresenta uma detalhada descrição da anatomia do esqueleto, a fim de agradar ao leitor que apreciava o tema mórbido da dissecção de cadáveres, em voga na literatura negra da época:

Os ossos não tinham já fibra de carne aderente, conforme ouvi aos facultativos examinadores. As cartilagens e ligamentos, conquanto articulassem a ossada, principiavam a esfacelar-se, e muitos se desfibravam ao contato do ar. $\mathrm{O}$ esqueleto estava de bruços; e cingida à volta do rádio e cúbito, ossos correspondentes ao antebraço, tinha uma espécie de pulseira, chamada manilha, com um retrato pendente, perfeitamente conservado no marfim, encastoado em oiro, com o rosto de esmalte, no reverso do qual se lê uma data, e as iniciais enlaçadas de Rafael Garção e Beatriz de Sousa. (E, p. 1339-1340). 
A narrativa indica que, anos depois de ter encontrado o esqueleto de Rafael, Nicolau volta a Portugal e manda exumar o corpo de Beatriz - uma reprodução, aqui, da tópica do desenterramento de cadáveres, recorrente no subgênero. Em vez de se utilizar do sobrenatural, no entanto, o narrador camiliano opta por desvelar a crendice do povo: "Os criados, suando de pavor, curvaram-se a remexer os ossos; mas a superstição, ou abalo sobrenatural, não ousou nenhum tocar-lhes; e, um após outro, fugiram da capela, ao verem desfigurarem-se medonhamente as feições do fidalgo" (E, p. 1350). Como ele sugere, não se tratava de assombração - “[...] Nicolau revolvia a língua na abóbada palatina, e tirava uns sons roucos, arrepiadores, como gritos de ave noturna" (E, p. 1350) -, mas da mais prosaica loucura, que teria acometido o orgulho ferido do marido traído, como explicara o narrador, parágrafos antes da cena de exumação: “A piedade não o forrava aos ímpetos de um ódio à sombra de Beatriz" (E, p. 1349).

Dessa forma, apesar de chamar a atenção do público com o seu título, O Esqueleto está longe de ser um exemplar típico da literatura negra, não sendo nem um elogio à virtude que, de fato, não estaria presente em nenhum dos personagens -, nem uma "história que faz arrepiar os cabelos", uma vez que não há a condução do suspense, mas somente a presença isolada de temas mórbidos em episódios específicos da narrativa. No prefácio de $O$ Que Fazem Mulheres (1858), por exemplo, Camilo já havia apresentado uma paródia dos clichês do romance gótico, mostrando o seu olhar crítico perante o subgênero:

É uma história que faz arrepiar os cabelos.

Há aqui bacamartes e pistolas, lágrimas e sangue, gemidos e berros, anjos e demônios.

[...] Isto sim que é romance.

[...] Escreve-se esta crônica enquanto as imagens dos algozes e vítimas me cruzam por diante da fantasia, como bando de aves agoureiras, que espirram de pardieiro esboroado, se as acossa o archote dum fantasma.

Tenebroso e medonho! É uma dança macabra! um tripúdio infernal!

[...] Há aí almas de pedra, corações de zinco, olhos de vidro, peitos de asfalto?

Que venham para cá. 
Aqui há cebolas para todos os olhos;

Broca para todas as almas;

Cadinhos de fundição metalúrgica para todos os peitos.

Não se resiste a isto. Há de chorar toda a gente [...]. $\left(Q F M^{4}\right.$, p. 1231-1232).

Esse diálogo crítico com os lugares-comuns da literatura negra está presente também em alguns contos de Camilo, que aqui merecem a nossa atenção ${ }^{5}$. Impressão Indelével (1842), publicado em 1857 em folhetim e coligido no mesmo ano na miscelânea Duas Horas de Leitura, foi alvo de especulações de alguns biógrafos e especialistas, que acusaram o autor de sofrer de necrofilia, "consequência da má interpretação da narrativa" (Cf. CABRAL, Alexandre, 1988, p. 543), que muitos reputaram como um episódio verídico que Camilo teria vivido em 1842 - cuja sugestão o escritor teria provavelmente manipulado para se autopromover. Nos capítulos iniciais, o narrador camiliano relata o seu namoro de infância com Maria do Adro, repleto de sentimentalismo romântico e bucólico: "Enfastia-te a simplicidade do conto? Era assim a nossa vida. Quando eu inventar, arrepiarei os cabelos às minhas imagens" ( $I I^{6}$, p. 295). Como ele irá depois tratar de uma exumação - que, teoricamente, arrepiaria os cabelos do leitor -, depreendemos nessa sentença que Impressão Indelével é uma história inventada, não tendo correspondência com a vida do autor.

Assim, o narrador-personagem cresce e é mandado por sua família para Lisboa e depois para a faculdade de Medicina no Porto, onde ele “[fez] ato de Anatomia, e [foi] premiado com um indulgente $R$ " (II, p. 296), ou seja, fora reprovado. Voltando à aldeia, ele recebe a notícia de que Maria havia morrido de tísica, o que o faz percorrer as campinas lembrando-se dela, numa passagem que remete ao lirismo sentimental: “A mesma fonte, a

\footnotetext{
${ }^{4}$ Ao longo deste trabalho utilizaremos a sigla QFM sempre que citarmos a obra $O$ Que Fazem Mulheres, de Camilo Castelo Branco. As citações são retiradas do volume II das Obras Completas (1983).

${ }^{5}$ Apesar de o foco deste trabalho ser o estudo do romance, encontramos a necessidade, neste capítulo, de abordar também alguns contos, a fim de reforçar os nossos argumentos.

${ }^{6}$ Ao longo deste trabalho adotaremos a sigla II sempre que nos referirmos ao conto Impressão Indelével, de Camilo Castelo Branco. As citações são retiradas do volume XI das Obras Completas (1990).
} 
mesma sombra de castanheiro, o mesmo socalco de relva, tudo, menos ela!” (II, p. 297). Tal lirismo é contraposto ao prosaísmo do capítulo seguinte, em que é chamado por seu cunhado para desenterrar o cadáver de Maria. Nessa passagem, o cômico de sua inépcia em medicina é retomado; ao ser inquirido se sabia "alguma coisa de anatomia", o personagem responde: "eu fiz um exame" (II, p. 298).

O capítulo que trata da exumação de Maria - reproduzindo a tópica do desenterramento de cadáveres - é composto dos lugares-comuns da literatura negra, com a atmosfera crescente de tensão e suspense. O terror é incitado através do ambiente sufocante, plasmado na lembrança do narrador de "que fuzilavam os relâmpagos duma trovoada de Agosto" (II, p. 298): "Entrei na igreja, alumiada a espaços pelo lampejo azul dos trovões, com religioso terror" (II, p. 299). Entretanto, o "riso desdenhoso" (Cf. II, p. 299) do cunhado serve como uma quebra da tensão, promovendo a ridicularização das superstições populares. A exumação, por sua vez, é descrita em seus detalhes macabros: "Tirei a terra às mãos-cheias, até sentir debaixo dos dedos [...] as formas de um corpo mole. Eu tinha a cabeça em lume; as pulsações do coração eram tão fortes que me agoniavam; não senti cheiro mau, senão o da terra impregnada de ossadas em pó, de vértebras, e pedaços de hábitos mortuários" (II, p. 299). Contudo, novamente a atitude prosaica do cunhado, que se ri perante a reação do narrador-protagonista - que afirma que "permaneci quieto, não sei que tempo, com os joelhos enterrados, e a face pendida sobre a face morta" (II, p. 299) -, contrasta com a atmosfera tétrica do relato: "Fitou-me com um sorriso... de médico, e afetou um ar de estranheza que eu antes quisera não fosse fingida" (II, p. 299).

O fato bizarro de o esqueleto da namorada de infância do narrador agora ficar no quarto de seu cunhado (Cf. II, p. 300), provavelmente como um adorno, é um índice da comicidade que a temática macabra adquire no conto. A descrição prosaica da anatomia desse esqueleto - em conformidade com o tema da dissecção de cadáveres - contrasta com a 
sentença poética com a qual ela é rematada, que acaba soando como falsa, uma vez que a descrição dos detalhes técnicos anatômicos não se coadunaria com a de um personagem efetivamente sensível e apaixonado:

A caveira é duma alvura de jaspe. Os dentes conservam o verniz do esmalte. As falanges daquelas mãos que eu beijava não têm a mais pequena mancha. O seio onde lhe bateu o coração está vazio; todavia a simétrica inserção das costelas fez-me lembrar a cúpula duma urna, onde um anjo do Céu veio buscar um coração que não era de cá. (II, p. 300).

Com isso, em Impressão Indelével, o sentimentalismo romântico do narrador é desmascarado, revelando a sua artificialidade. Ao mesmo tempo, a atmosfera tétrica, apesar de reproduzir os lugares-comuns da literatura negra, é o tempo todo interrompida, chamando o leitor para a realidade, impedindo a fruição do macabro. O conto A Caveira, por sua vez, presente nas Cenas Contemporâneas, publicadas em 1855, também traz a tópica do desenterramento do cadáver da mulher amada. Nessa narrativa, o protagonista é D. João de Noronha, um velho que conta ao narrador - que sugere ser o próprio Camilo - a história da "caveira, contida em uma redoma de vidro, com pedestal de pau-preto, enviesado de arabescos de marfim" ( $C^{7}$, p. 399), presente em seu escritório. Segundo o personagem, a caveira seria de Marta, a mulher que amou durante a juventude, e que o teria trocado por outro rapaz. Este rapaz, no entanto, teria enfrentado um terceiro pretendente da moça num duelo, que resultara na morte de ambos; ao saber do assassinato do amante, Marta teria tido uma síncope e falecido. Anos depois, João de Noronha resolve exumar o cadáver da amada, atitude que relata em seus detalhes, na velhice, ao narrador camiliano:

\footnotetext{
${ }^{7}$ Ao longo deste trabalho adotaremos a sigla $C$ sempre que citarmos o conto $A$ Caveira, de Camilo Castelo Branco. As citações são retiradas do volume XIV das Obras Completas (1991).
} 
Era meia-noite, e perpassavam em redor de mim as larvas do terror, agitadas pelo lampejar trêmulo das lâmpadas, suspensas no altar do Santíssimo Sacramento. [...]

Não posso dizer-lhe até que ponto fui enganado pelas larvas que a desvairada fantasia, ou a misteriosa realidade revocou em volta de mim... Estou quase jurando-lhe que a vi... a ela... como nos dias da sua esplêndida formosura iluminada pelo resplendor da sua inocência [...]. Foi assim que eu a vi, enquanto o eco da enxada, que feria o seio da sepultura, reboava nas naves da igreja... Gelava-se-me de terror o pensamento... a fantasia esfriavase ao roçar pela mortalha daqueles ossos, e eu sentia-me morto em metade da vida, quando a terra sacudida da enxada me vinha cair aos pés.

E depois... as larvas, que a razão não podia espavorir, tornavam a cingir-se com os pilares da nave, a pendurar-se nas grades do coro, a tremularem por entre os cortinados dos altares, e a esvoaçarem na abóbada do templo como nuvens escuras, espedaçadas pela tempestade.

Erguera-se do túmulo para ajoelhar, a meus pés... tinha a face lacerada pelos vermes. E era bela ainda... Devo ser sincero, meu amigo... É impossível que a imaginação me mentisse... Ouvi-lhe a sua voz... senti o frio das suas mãos... ergui-a de meus pés... perdoei-lhe... chorei com ela...

A voz dum homem chamou a minha alma à realidade acerba daquela cena, que se me figurava um sacrilégio, uma profanação.

Era o coveiro, que me dizia: "A enxada já topou com os ossos". ( $C$, p. 409).

Nesta passagem, o narrador utiliza algumas das principais estratégias da literatura negra para suscitar o medo no leitor: o ambiente sufocante e noturno, o pavor do personagem, o macabro - intensificado pela visão repulsiva das larvas - e a aparição sobrenatural. Entretanto, se no início a narrativa hesita sobre a efetividade das impressões descritas - João de Noronha afirma não saber se sua visão foi fruto da "fantasia" ou da "misteriosa realidade" -, no final a tensão crescente do relato é quebrada pela voz do coveiro, que "chama à realidade" tanto o protagonista, quanto o leitor, impedindo, assim, a fruição do terror. O narrador camiliano, por sua vez, não parece acreditar no sobrenatural - colocando, assim, a própria história em cheque -, como ele afirma ao comentar sobre as longas explanações do velho acerca da vida após a morte: “Aprendi com ele a ciência do espiritualismo. Se depois me materializei, é porque a faísca daquele gênio não me tinha abrasado mais que a superfície da matéria" ( $C$, p. 411).

Outro conto que dialoga com a literatura negra, mas que, no entanto, é repleto de passagens cômicas - não havendo, portanto, o desenvolvimento do suspense e do terror - é 
História de uma Porta, publicado em 1863 na miscelânea Noites de Lamego, que "reúne escritos avulsos, coligindo colaborações dispersas em vários periódicos" (Cf. SOUSA, S., 2009, p. 36). Contada por um narrador-personagem que sugere ser o próprio Camilo, de passagem em Bragadas para pescar trutas, a narrativa inicia-se de forma picaresca: tendo-se afastado "duas léguas de casa" devido a "uma truta velha, de cabelos brancos, como lá dizem. Desta macróbia se dizia que tinha impunemente engolido anzóis! O peixe era um Mitridates da sua classe" $\left(H P^{8}\right.$, p. 1019), o narrador é surpreendido pela noite e procura um abrigo para dormir. Ao perguntar a um popular onde ele poderia se hospedar, acaba por fazer troça do linguajar rural:

- Vá vossemecê por esse quinchoso abaixo; lá ao todo fundo carregue à sua esquerda, e salte um portelo que não tem que errar. Vossemecê vai rebentar mesmo à porta do tio João Barroso.

- Rebentar?! - articulei eu, assustado da profecia.

- Sim, à porta do tio João Barroso, que é o lavrador maior da freguesia.

Rebentar, felizmente, era sinônimo de sair ou chegar.

Rebentei, pois, à porta... À porta? Hei de eu chamar porta a isto? $(H P, \mathrm{p}$. 1019-1020, grifo do autor).

A partir daí, a narrativa passa a explorar o mistério da porta, repleta de "[...] rendilhados, festões, laçarias, refendimentos, figuras e relevos do mais luxuoso cinzel. Era alteroso o portão. As ombreiras eram colunas recebendo nos capitéis uma cúpula triangular recamada de florões, com grande folhagem, donde surdiam anjos dedilhando cítaras [...]" (HP, p. 1020). O mistério ficava por conta do contraste entre o seu luxo e a pobreza do restante da casa: "Eu ia perguntar ao hospedeiro, dono daquele magnífico portal, como era que a fachada do edifício escondia uns quase pardieiros, uma cozinha térrea, e uns sobrados com umas janelas de pedra bruta, e portadas de madeira nem sequer desbastada pelo cepilho!" (HP, p. 1021).

\footnotetext{
${ }^{8}$ Ao longo deste trabalho utilizaremos a sigla $H P$ sempre que citarmos o conto História de uma Porta, de Camilo Castelo Branco. As citações são retiradas do volume XIII das Obras Completas (1991).
} 
Após o narrador passar a noite curioso, o anfitrião lhe conta no dia seguinte que seu tio, padre Domingos, havia ido ao Brasil e lá feito fortuna, tendo retornado a Portugal com "um mulato já espigadinho" (HP, p. 1024), a quem, no leito da morte, chamara de filho (Cf. $H P$, p. 1025). Antes de adoecer repentinamente, o tio mandara ordenar o rapaz - que passou a ser conhecido como padre Vicente -, e começara a construir um palacete, iniciando pela porta. A construção, no entanto, fora interrompida com o seu falecimento, uma vez que todo o dinheiro - que deveria ficar de herança para a família - acabou sendo roubado, logo após a sua morte, pelo filho, que desaparecera. Anos depois, teria surgido um romeiro "assim a modo de anegriscado", que "os velhos de Bragadas começaram a espalhar que [...] era o padre Vicente, que andava a fazer penitência" (HP, p. 1026). Após o falecimento do romeiro, à porta da adega do hospedeiro, começaram a surgir boatos de assombração: "Ninguém lá entra, assim que é noite. Ouve-se remexer dinheiro, e arrastar ferros, e dar gemidos. Já lá têm ido padres, requerer a alma e fazer as rezas; mas é tempo perdido. Se não é a alma penada do padre Vicente, é a de meu tio" (HP, p. 1027).

Ao expor ironicamente que "confesso que me pus a caminho, enquanto era dia, com medo de encontrá-las ambas, ou pelo menos uma das almas" (HP, p. 1027), o narrador camiliano acaba por zombar da crença no sobrenatural, típica das superstições populares - e, consequentemente, da literatura negra que nelas se baseia. Em suas palavras finais, nas quais reflete que, "pensando neste caso vinte e dois anos depois, de mim para mim tenho que o padre Vicente não era o peregrino que morreu à porta da adega [...]. O padre inquestionavelmente morreu bispo. Se morreu em cheiro de santidade, não ouso asseverá-lo sem ler os necrológios" (HP, p. 1027), Camilo-narrador questiona não somente o caso sobrenatural, mas também a justiça - divina e dos homens -, que não punira o padre.

Assim sendo, nas obras aqui analisadas, verificamos que Camilo geralmente evita o sobrenatural e, quando o utiliza, acaba sempre por questionar a sua autenticidade, muitas 
vezes ridicularizando a crença do povo. Quando há o desenvolvimento do suspense, a tensão crescente costuma ser interrompida por digressões e comentários jocosos, que impedem a fruição do terror, chamando o leitor para a realidade. A atmosfera macabra, por sua vez, se não é alvo de riso, é utilizada em episódios pontuais, como forma de agradar ao leitor. O enredo sentimental, por outro lado, típico do romance gótico, não é construído pelo autor com o intuito didático de promover a virtude, uma vez que o narrador não move a compaixão do leitor para com as vicissitudes de seus personagens, que, aliás, possuem um caráter duvidoso.

Nas palavras de Ana Maria Marques, “imitando as obras francesas ou inglesas de maior sucesso" - ou fingindo imitá-las -, alguns autores como Camilo "não deixam, contudo, de perceber quanto nelas havia de artificial ou convencional e não se coíbem de integrar nas suas narrativas a sátira ao gênero negro" (2010, p. 72). Com isso, através de uma aparente adesão aos pressupostos da narrativa fantástica - sobretudo da literatura negra ou gótica -, a fim de atender às demandas do público que avidamente consumia essas narrativas, Camilo propunha a crítica não somente a esse modelo literário, como também às superstições nas quais ele se alicerçava, frustrando as expectativas de leitura, criando histórias que propositadamente não faziam arrepiar os cabelos. 


\subsection{A Luneta Mágica que torna cético ou ludíbrio do mundo e dos homens}

O romance A Luneta Mágica foi publicado em livro em 1869, depois de ter sido lançado, no ano anterior, em folhetins. Apesar de não ter passado da primeira edição durante o século XIX, foi uma das obras mais vendidas de Joaquim Manuel de Macedo durante o século XX, tendo tido dez edições pela Editora Ática. Como o próprio título indica, trata-se de um romance que se utiliza da tópica sobrenatural do artifício mágico, presente em várias narrativas fantásticas da época ${ }^{9}$. O narrador-protagonista é Simplício, um míope que pede a ajuda de um mago, o Armênio, funcionário da ótica do Reis, para enxergar. Primeiramente o Armênio lhe dá uma luneta que, após três minutos de focalização, permite a Simplício ter a visão do mal, o que lhe traz muitos dissabores. Depois o mago fabrica uma luneta que o faz ver somente o bem, o que lhe causa também infelicidade. No fim da história, o Armênio impede Simplício de se suicidar, dando a ele uma luneta do bom-senso.

No início da narrativa, Simplício se define como um "míope; pior do que isso, duplamente míope, míope física e moralmente" ( $L M^{10}$, p. 7). Se “a duas polegadas de distância dos olhos não disting[ue] um girassol de uma violeta" ( $L M$, p. 7$)$, o protagonista

\footnotetext{
${ }^{9}$ Segundo Flora Süssekind, "a fonte provável da história de A luneta mágica [...] é Meister Floh, 'conto de fadas' humorístico, escrito entre 1821 e 1822 por E. T. A. Hoffmann. Nele, é ao recluso e solitário Peregrinus Tyss que o Mestre Pulga faculta o uso de uma lente microscópica, por fim rejeitada, que, de dentro do olho, lhe permite ler a mente alheia e orientar-se com mais desenvoltura pelo mundo exterior à sua casa" (1996a, p. 31). Já para Brito Broca, Macedo teria se inspirado na luneta que traz o conhecimento do âmago das pessoas, ofertada ao protagonista por Satã, em Les Mémoires du Diable (1837-1838), de Frédéric Soulié, obra que também teria influenciado Ao Correr da Pena (1854-1855), de José de Alencar (Cf. BROCA, 1962, p. 32-36). Por outro lado, o romance macediano faz referência à loja do Reis, um "famoso armazém de instrumentos óticos da Rua do Hospício" (MACEDO, 1977, p. 85), que também aparece em Ao Correr da Pena - "Vá a casa do Reis, na Rua do Hospício $\mathrm{n}^{\circ}$. 72. É a melhor loja de instrumentos de ótica e de física que há nesta cidade" (ALENCAR, 2004, p. 41-42) -, o que demonstra a sua relação com o folhetim alencariano. Com isso, percebemos que A Luneta Mágica foi influenciada por diversas narrativas fantásticas, assunto com o qual não iremos trabalhar aqui, uma vez que é de nosso interesse analisar o diálogo de Macedo com os lugares-comuns e as expectativas de leitura do subgênero fantástico, e não com obras específicas. Ao mesmo tempo, ao verificarmos que a temática do artifício mágico, que permite conhecer o pensamento dos outros, é reproduzida em várias obras da época, depreendemos que essa tópica acabou por se tornar convencional na narrativa fantástica, não sendo mais característica de um só autor.
}

\footnotetext{
${ }^{10}$ Ao longo deste trabalho adotaremos a sigla $L M$ sempre que citarmos o romance A Luneta Mágica, de Joaquim
} Manuel de Macedo. As citações são retiradas da $4^{a}$ edição publicada pela Editora Ática (1977). 
afirma além disso que "sou sempre escravo das ideias dos outros; porque nunca pude ajustar duas ideias minhas" (LM, p. 7). Ao receber a notícia de que tinha sido incluído na lista dos jurados da freguesia, Simplício descobre que tem o senso comum: "O juiz de direito que presidira à revisão da lista dos jurados, resolvera um problema até então intrincadíssimo, declarando que eu podia ser jurado, e que por consequência eu tinha senso comum, condição exigida por lei” ( $L M$, p. 13). Com isso, Macedo aproxima Simplício da maioria das pessoas: "sinto-me cheio de orgulho pela convicção legalmente autorizada de que tenho senso comum, e apoderado de irresistível vaidade com a presunção de que sou igual a muitos magistrados, deputados, senadores, ministros e conselheiros de estado, pela falta de bom-senso ou senso raro" $(L M$, p. 14).

Dessa forma, apesar de ser visto como portador de um caso extremo de miopia, Simplício de fato representa todos aqueles que são cegamente influenciáveis pela opinião pública, sendo isentos de senso crítico e incapazes de enxergar a realidade com os próprios olhos, impossibilitados de perceberem o quanto são manipulados, explorados e enganados. Como explica Susi Frankl Sperber, "fica em nossas mãos a ideia de que o conjunto de noções necessárias e suficientes para se atingir o discernimento é algo que precisa da magia, porque é material que está em falta não apenas para Simplício, mas para a comunidade em que está inserido" (2003, p. 434). Para a pesquisadora, o romance discute a "conquista da liberdade e fundamentação do livre-arbítrio" (2003, p. 433), a "busca da liberdade pessoal, individual" (2003, p. 437), tema que será levado à esfera coletiva em As Vítimas-Algozes, obra publicada no mesmo ano ${ }^{11}$.

Simplício, assim como as pessoas que também são “escravas das ideias dos outros", é um tolo, enganado pelos mais ardilosos. Órfão e herdeiro de grande fortuna, o protagonista é manipulado pelos seus familiares, ignorando o fato de serem falsos e

\footnotetext{
${ }^{11} \mathrm{O}$ romance As Vítimas-Algozes será objeto de nossa análise no capítulo 7.2.
} 
aproveitadores, acreditando nas suas pretensas boas intenções. Seu irmão Américo, “testamenteiro e inventariante" de sua herança, a qual, segundo Simplício, "ele emprega e zela, certamente só em meu proveito, mas sem me dizer como, nem jamais dando-me contas; e portanto pensando, negociando e sofrendo por mim o meu pobre irmão!” ( $L M$, p. 10$)$, é uma representação do político corrupto, que tem sede de poder e dinheiro, apesar de sua aparência patriótica:

Convém saber que meu irmão saiu eleito deputado na última designação constitucional, e mandou fazer a sua libré parlamentar ainda antes de ser reconhecido representante legítimo do povo soberano que anda de paletó e de jaqueta.

Deste fato e da sua observação concluí eu em minha simplicidade que o mano Américo vive doido por ser ministro para fazer o bem da pátria. ( $L M$, p. 9).

Sua tia Domingas, por outro lado, é a personificação da hipocrisia religiosa, "uma senhora que anda sempre de rosário e em orações" ( $L M$, p. 8), mas que "não deu nem dá um vintém de esmola ao pobre que lhe bate à porta, pretextando sempre que tem muita vontade de fazer esmolas evangélicas; porém que ainda não achou meio de esconder a mão esquerda o óbulo da caridade pago pela mão direita" $(L M$, p. 8). Sem ironia, o inepto narrador afirma que “estou tão profundamente convencido da pureza dos sentimentos religiosos da tia Domingas, que [...] vivo em sustos de que algum dia a piedosa senhora mande amputar a mão esquerda para conseguir dar esmolas com a mão direita” ( $L M$, p. 8). Já a sua prima Anica, que aparenta estar apaixonada por ele, representa as mulheres interesseiras:

a prima Anica já sonhou três vezes com mudança de gabinete [do mano Américo], e com correios e ordenanças à porta de nossa casa. Inocente menina! é um anjo: os seus sonhos são piedosos como as vigílias da tia Domingas, sua mãe, e patrióticos, como os cálculos do mano deputado; ela diz com virginal franqueza que tem meia dúzia de parentes pobres a arranjar, quando o mano Américo for ministro. [...] Já fez um ponto de fé 
deste suavíssimo princípio: "a caridade deve começar por casa”. (LM, p. 910 , grifo do autor).

É no tribunal que Simplício conhece um velho que o recomenda ao ótico Reis, cuja descrição se aproxima de uma personificação da própria ciência. Nas palavras do personagem, o Reis

Dá, reproduz os meios conhecidos, aperfeiçoa-os e inventa novos para se fazer a paz e a guerra, a guerra, dando precisão, segurança às pontarias das peças de artilharia, a paz, oferecendo balanças e níveis de todas as qualidades, alguns dos quais devem poder marcar o peso e o nível dos interesses de quaisquer beligerantes, e além desses os mais perfeitos instrumentos para demarcação dos limites dos Estados; governa nos mares com as melhores bússolas; é senhor do sol e da lua, e de todos os planetas pelos mais fortes telescópios; conhece e domina os animais invisíveis pela força engrandecedora dos microscópios, vê o fundo tenebroso das minas, tem o cetro da física, o império da química, a soberania da eletricidade pela magia dos seus instrumentos, marca o tempo, prediz o calor e a chuva [...]. $(L M$, p. 17).

Reis, o homem da ciência, é capaz de tudo isso, menos de curar a miopia extrema de Simplício, que, como sabemos, é também uma miopia moral: "Não tenho recurso que lhe aproveite" ( $L M$, p. 19). Vista como uma panaceia que resolveria todos os problemas da humanidade, a ciência, para Macedo, apesar de trazer o progresso material, é incapaz de solucionar as questões de ordem moral da sociedade. Assim, em contraposição à ciência, o romance apresenta a magia, a fantasia, representada pelo Armênio, que se propõe a dar a visão a Simplício. Utilizando-se da tópica da "transação com a magia em proveito do interesse pessoal" ( $L M$, p. 22$)$, presente em muitas narrativas fantásticas de teor satânico - dentre as quais talvez a mais célebre seja o Fausto (1832), de Goethe -, Macedo reproduz, de uma só vez, vários lugares-comuns da temática do feitiço, com a evocação do sobrenatural, das forças ocultas e demoníacas, através de palavras mágicas, símbolos e objetos cabalísticos, num ambiente misterioso: 
O gabinete do armênio estava todo pintado de negro, tendo em branco os caracteres especiais de todos os dias da lua marcados pelas vinte duas chaves do Tarot e pelos sinais dos sete planetas; no meio do teto também negro viase a figura do pentagrama em vermelho vivíssimo.

No fundo do gabinete uma mesa servia de altar da magia; junto a ela uma pele de leão tapizava o chão, imenso pano vermelho cobria a mesa, e nesse pano eram mais de cem as figuras cabalísticas pintadas em negro.

Sobre o altar maldito descansavam os instrumentos da magia e entre outros a vara mágica, a espada, a taça e a lâmpada; a um lado, no chão, estava a trípode. Globos, triângulos, a figura do diabo, a estrela de seis raios, o abracadabra $^{12}$, as combinações do triângulo, e uma infinidade de símbolos enchiam a mesa e o gabinete.

O armênio mágico vestia a roupa própria do sábado, simples túnica cinzenta com caracteres bordados em seda cor de laranja, tendo ao pescoço uma medalha de chumbo com o sinal cabalístico de Saturno e as palavras ou nomes - Amalec, Aphiel, Zarabiel, e trazia na cabeça um barrete triangular de cor branca com o pentagrama em cor negra. [...]

De súbito o armênio levantou-se, como cedendo a impulso irresistível, e quando ele se levantou os sinos deram sinal de meia-noite.

- É a hora, disse ele [...].

Em seguida ouvimo-lo exorcizar em latim os espíritos elementares, e falar e evocar as ondinas, as salamandras, os silfos e os gnomos; empregou-se assim meia hora pelo menos a entender-se com invisíveis e duvidosos ou quiméricos seres.

Apenas acabou de falar, lançou sobre o fogo pequenas porções de diagrídio, escamônea, pedra-ume, enxofre e assa-fétida. ( $L M$, p. 23-25, grifo do autor).

A própria definição da hora da magia - à meia-noite - acaba por reforçar nesta passagem o uso das convenções da literatura fantástica, seguidas minuciosamente aqui por Macedo: segundo Vagner Camilo, a meia-noite "d[á] guarida ao avesso das formas e existências reveladas pela luz do dia e, por extensão, da razão. Daí os sentimentos mais indefiníveis e os acontecimentos mais anormais ou mesmo... sobrenaturais" (1998, p. 161, grifo do autor). Apesar de não ridicularizar explicitamente as superstições populares - uma vez que não escarnece do poder do sobrenatural -, a detalhada descrição da magia e do ambiente sinistro também não aterrorizam o leitor. O excesso de informações, em vez de alimentar o suspense e aumentar a tensão da narrativa, acaba por torná-la artificial. Ainda que o personagem declare o seu pavor - "ele [o mago] se concentrava; nós tremíamos" ( $L M, \mathrm{p}$.

\footnotetext{
${ }^{12}$ Apesar de a palavra "abracadabra" estar hoje associada a mágicos de palco e ilusionistas - o que poderia fazer com que ela fosse lida de forma cômica -, o termo é aqui utilizado por Macedo em sua acepção original, ou seja, uma palavra mística gravada em talismãs e amuletos (Cf. Dicionário Houaiss da Língua Portuguesa, 2001).
} 
24) -, o leitor acaba por não se arrebatar pelo terrífico, divertindo-se com ele: é o tom cômico, afinal, que prevalece no romance.

O Armênio dá a Simplício uma luneta que não apenas cura a sua miopia física, mas também a sua miopia moral: se ele a fixasse em algum objeto por mais de três minutos, passaria a enxergar o seu mal ${ }^{13}$. Como ele alerta, "três é o número simbólico, e para ti será o número simples, o da visão da superfície e das aparências; não a fixes por mais de três minutos sobre o mesmo objeto, ou aborrecerás o mundo e a vida" ( $L M, \mathrm{p} 26$, grifo nosso). Assim sendo, de acordo com as palavras proferidas pelo personagem, a visão "normal" adquirida por Simplício - e que todas as pessoas possuiriam - não passaria de uma "visão da superfície e das aparências"; já a visão obtida através da fixação da luneta após três minutos permitiria o desvelamento das aparências e, portanto, a compreensão da realidade, o que tornaria o seu observador cético e "aborrecido do mundo e da vida".

Introduzir o ceticismo em Simplício era a intenção do Armênio desde o início, como ele ameaçara o Reis: “duvidam do meu poder, e vou prová-lo [...]; infiltrarei o ceticismo na alma de um inocente mancebo" ( $L M$, p. 20). Esta temática pode ser encontrada, por exemplo, em Macário, de Álvares de Azevedo - com quem Macedo possivelmente dialoga também aqui -, peça na qual Satã é responsável pela germinação do ceticismo: nas palavras do personagem-título, "talvez um anjo mau soprasse no meu espírito as cinzas sufocadoras da dúvida" (2000, p. 552) ${ }^{14}$. Simplício passa, assim, a desvelar as máscaras sociais principalmente de seus familiares, descobrindo que é explorado e cercado de pessoas sem caráter. Sobre o seu irmão - que, como vimos anteriormente, representa os políticos corruptos - , o personagem afirma que

\footnotetext{
${ }^{13}$ Segundo o Armênio, após treze minutos de focalização haveria a possibilidade de enxergar o futuro; entretanto, a visão do futuro só aparece no final do romance, quando o personagem mira o Rio de Janeiro, passagem que iremos discutir mais adiante.

${ }^{14}$ Para uma melhor compreensão sobre a obra de Álvares de Azevedo, consultar O Belo e o Disforme: Álvares de Azevedo e a ironia romântica (1998), de Cilaine Alves Cunha.
} 
o político patriota era apenas um ambicioso vulgar! o nome da pátria era uma alavanca, a dedicação ao povo um meio de construir escada: Américo queria subir, queria ter influência [...]; somente porém por cálculos de fortuna, somente para explorar as posições oficiais em seu proveito material. [...] Américo negocia com a legítima paterna da prima Anica, com a fortuna da tia Domingas e com a minha; convenceu-nos a todos de que perdêramos a quarta parte do que possuíamos na quebra das casas bancárias em 1864; ele porém ganhou nessa crise setenta e cinco por cento da soma das nossas três fortunas prejudicadas, isto é, aumentou a sua riqueza na proporção exata de nossas perdas. ( $L M$, p. $34-35)$.

A sua tia, por sua vez, “é invejosa e má; benze-se, levantando aleives às vizinhas, ou propalando as suas fraquezas" ( $L M$, p. 35). A hipocrisia religiosa, típica de muitas pessoas que agem da mesma forma, é aqui desmascarada: "Pela força do hábito os lábios da tia Domingas estão em movimento incessante, porque sua boca repete maquinalmente as orações de seu rosário; interrompe, porém, as orações a cada instante [...] para proferir pragas contra os escravos, chamando mil vezes pelo nome do diabo" ( $L M$, p. 36). Já a prima só pensa em casar-se pelo dinheiro, assim como várias mulheres da época:

o coração era uma pedra de gelo, a alma era o espírito reduzido a cálculo [...]; no seu coração li a indiferença e a tristeza, na sua alma a ambição de um marido rico [...]; era, é a mulher fria, egoísta, positiva, material, incapaz de amizade, e ainda menos suscetível de amor [...]; eu era em sua alma uma hipótese de marido, e como letreiro, como nome da minha imagem, li em caracteres aritméticos a soma das legítimas, das heranças que me haviam deixado meu pai e minha mãe!... ( $L M$, p. 32).

O ceticismo, todavia, ao desvendar a cruel realidade e trazer o "aborrecimento do mundo e da vida", acaba por tornar o protagonista misantropo: "Não creio em homem algum, em mulher alguma: sou a descrença viva, ceticismo animado. Desconfio de todos" ( $L M, \mathrm{p}$. 58). Além disso, devido ao seu poder de desvelar as máscaras sociais, o cético é desprezado pelas pessoas, que não desejam que lhe apontem seus erros: "Um por um todos se arreceiam de mim, e todos me detestam. Em toda parte sou por todos enxotado, de toda parte repelido" 
( $L M$, p. 58). Em consequência, o ceticismo é visto pela sociedade hipócrita como loucura:

"Por consequência estou definitivamente declarado doido pela opinião pública" ( $L M$, p. 61):

Um exemplo: um desses homens de palavra solta e descomedida declara sem cerimônia e declinando nomes que tal e tal sujeitos que chegaram a titulares e são considerados, lisonjeados e adulados pela sua riqueza nas mais elegantes sociedades, mereciam antes estar na casa de correção por terem enriquecido com abusos escandalosos e crimes, de que ele faz a história. - É doido.

Outro exemplo: um jornalista que escreve sem luvas de seda, chama na imprensa ao ministro que dilapida, dilapidador; ao funcionário ou administrador que rouba, ladrão; e assim por diante sem limar o verso para que não fira. Que doido!

[...] Porque na sociedade a maior prova, o mais seguro sintoma de loucura é dizer a verdade sem rebuço, mesmo quando a verdade pode ser desagradável ou ofensiva. (LM, p. 64)

Com isso, o narrador sugere que o ceticismo, em sua plenitude, não é um bem almejado, uma vez que traz infelicidade e impede que o pessimista viva em sociedade: “Aborreço a vida, mas sendo obrigado a viver, como vai correr a minha vida?" ( $L M$, p. 58$)$. Por outro lado, ao fazer Simplício defrontar-se - e horrorizar-se - com a sua própria imagem no espelho, Macedo parece lembrar que falta ao misantropo um pouco de autocrítica: "Eu estava em convulsão... detestava-me... tinha horror de mim próprio, desprezo pela minha torpe individualidade" ( $L M$, p. 81). Dessa forma, a narrativa mostra que o ceticismo, quando levado ao extremo, acaba por ser não apenas prejudicial àquele que descrê, mas também ridículo, uma vez que faz com que o pessimista veja todos os aspectos da vida de forma negativa, como na passagem esdrúxula em que o narrador-protagonista enxerga o mal até mesmo num beija-flor:

[...] ah! essa avezinha tão mimosa e tão linda é um monstro que me inspira aversão [...].

Egoísta, falso, incapaz de afeição durável, o perverso abusa dos seus encantos, e beija, profana e atraiçoa todas as flores, licencioso e infame, poluindo seus néctares e ostentando após a mais bárbara indiferença, a mais ostentosa e ilimitada inconstância [...]. 
Finalmente assassino e destruidor, ele mata e devora em cada dia dezenas e dezenas de insetos inocentes, fracos e incapazes de defender-se, ousando sem continência, nem respeito ir arrancá-los do mais doce asilo, do seio mimoso das flores!...

Hoje criei ódio aos beija-flores, passarinhos devassos, desmoralizados, traiçoeiros e malvados.

Flores da terra! acreditai na minha luneta mágica: tende medo dos beijaflores! ( $L M$, p. 48$)$.

Assim, após observar a sua imagem no espelho, Simplício quebra a luneta e volta a encontrar o Armênio, que lhe fabrica outra: dessa vez, trata-se de uma luneta que lhe permite enxergar somente o bem nas pessoas, ou seja, que lhe dá uma visão otimista e idealista do mundo. Ao contrário, por exemplo, da Lira dos Vinte Anos, de Álvares de Azevedo, na qual o poeta idealista dá lugar ao cético ${ }^{15}$ - "Nos mesmos lábios onde suspirava a monodia amorosa, vem a sátira que morde. [...] Goethe depois de Werther criou o Faust. Depois de Parisina e o Giaour de Byron vem o Cain e Don Juan - Don Juan que começa como Cain pelo amor, e acaba como ele pela descrença venenosa e sarcástica" (AZEVEDO, 2000, p. 191) -, em A Luneta Mágica a visão cética é seguida da idealista. Por conseguinte, o protagonista volta a ser o mesmo tolo ingênuo que era antes das lunetas; de fato, parece-nos até que ele se torna mais inepto, uma vez que passa a encontrar justificativas para os atos deploráveis dos seus familiares:

Anica é um anjo de inocência e simplicidade [...]. O que eu julgara nela gelo do coração era virginal recato, o que eu tomara por cálculo material e egoísta era a reflexão e a sabedoria instintiva de uma mulher-modelo [...]. Encontrei a minha imagem na alma de Anica; [...] encontrei-a amada, ternamente amada, encontrei-a cercada dos cuidados e do interesse de um sentimento tão profundo como generoso que só lembrava a minha fortuna, a minha riqueza com o receio de que fossem motivos que excitando a ambição de alguma outra mulher, prejudicassem às aspirações do seu amor desinteressado e puro. $[\ldots]$

\footnotetext{
15 Como explica Cilaine Alves, “denominado 'binomia' por seu criador, o dualismo sistêmico orienta a expressão poética ora para uma esfera transcendental e inatingível, ora para a vida humana em seus aspectos degradantes, atendo-se sobretudo aos aspectos viciosos e vis do comportamento" (1998, p. 27). Tratar-se-ia, assim, de uma "ironia da forma", "que desemboca frequentemente na autoparódia e no cinismo, gerando na obra uma oscilação entre um eu poético ingênuo e outro cínico" (1998, p. 92).
} 
A tia Domingas era a devoção, a piedade personalizada. Aos pobres negava esmola à nossa vista, e semeava benefícios às escondidas: era a caridade do evangelho, o bem que fazia, só ela o sabia. [...]

O mano Américo é o tipo da dedicação fraternal: vive pensando em mim, negociando por mim, e explorando em meu favor e benefício as evoluções, revoluções, e combinações da Praça do Comércio.

Em sua abnegação sublime deixa intatas e não desviadas do emprego em que se acham as somas da sua riqueza própria, e, mercê de uma procuração que assinei, negocia com a minha fortuna, jogando na praça: se perde, perco eu e é justo; se ganha, tira dos lucros a sua porcentagem, o que é justíssimo [...].

O que tem sempre aumentado é a fortuna do mano Américo que nunca perde, e ganha sempre; mas a isso nada tenho que dizer; porque o mano Américo só se ocupa de mim, e faz o sacrifício de jogar na praça somente com o meu dinheiro, e em tal caso quando há perdas, é evidente que eu devo carregar com elas, tanto mais que quando há lucros, meu irmão os reparte comigo. (LM, p. 109-111).

A estupidez de Simplício, estimulada pela bonomia trazida pelo uso da luneta, é levada agora ao extremo, uma vez que o personagem acaba sendo enganado por toda a freguesia: "Vi-me constantemente cercado de amigos, em quem aplaudi e venerei virtudes exemplares; paguei-lhes jantares e ceias, e a quase todos emprestei dinheiro, que não me restituíram somente porque a fortuna lhes correu adversa" ( $L M$, p. 135). Dessa forma, o idealismo extremo é também visto por Macedo como prejudicial, uma vez que o crédulo é explorado e ridicularizado pela sociedade, como alertam as palavras do Reis:

- [...] a sua pretendida visão do bem o tornou alvo das zombarias e do ridículo... [...] Não há vadio, nem trapaceiro que não tenha abusado da sua boa-fé; [...] todas as senhoras conhecem já a sua... mania de se supor amado por elas sem exceção de uma só, e de amar igualmente a todas, e isso as diverte de modo tal, que nenhuma o vê que não precise de grande esforço para conter o riso... (LM, p. 144).

No capítulo oitavo da segunda parte do romance ${ }^{16}$, Simplício é convidado para uma orgia. Ao criticar a libertinagem da vida boêmia, temática que aparece em algumas narrativas fantásticas - dentre as quais se destaca Noite na Taverna, de Álvares de Azevedo -,

\footnotetext{
${ }^{16}$ A segunda parte do romance é dividida em duas seções, intituladas "Introdução" e "Visão do bem", ambas compostas por dezenas de capítulos; referimo-nos, aqui, ao capítulo oitavo da segunda seção.
} 
o narrador se utiliza dos lugares-comuns da literatura sentimental, reproduzindo a tópica da prostituta regenerada:

Contemplando essa vítima do mundo, e dos homens, essa embriagada adorável, essa virtude cheia de manchas, esse querubim profanado, essa mulher formosa de corpo aviltado e alma pura, esse coração todo amor, essa Madalena que se torturava no vício, que se atribulava na orgia, que se degradava na embriaguez, que antes da morte e com severa consciência condenava o corpo à corrupção, à podridão, às extremas e esquálidas misérias da terra, e tinha a alma arrependida já metade no céu, tive ímpetos de correr a beijar-lhe os pés, e de bradar-lhe: "acorda! surge do sono da embriaguez! eu te compreendo e te amo, eu te regenero, dando-te o meu nome!" (LM, p. 117).

Todavia, não podemos nos esquecer de que o idealismo incitado pela luneta, que só permite a visão do bem, impede que Simplício veja a realidade. Ele acaba, de fato, sendo enganado por essa mulher, que lhe pede grandes somas de dinheiro para supostamente contribuir em obras de caridade (Cf. $L M$, p. 136): "me apontam, como estúpida vítima de homens sem consciência, e de uma mulher sem brio, e sem coração...” (LM, p. 143). Ao reconhecer que o seu otimismo só lhe trouxera decepções, o narrador-protagonista defende o ideal de morte romântico, como forma de fugir da realidade: "Não há dor, nem ânsias, nem moléstias, nem privações, nem miopia na imensa e refulgente região da morte!” ( $L M$, p. 152). Antes de se suicidar, porém, atirando-se de um morro, Simplício analisa a pátria:

Fixei pois a luneta mágica sobre a cidade do Rio de Janeiro e vi...

Durante os três primeiros minutos: força vital, prodígios de riqueza do solo do Império, majestade da natureza e em grande número de homens incapacidade, inveja, capricho, nepotismo, vaidade comprometendo tudo, sacrificando tudo, perdendo tudo no culto do egoísmo, e de ruins paixões. Depois de três minutos até treze: a mesma e ainda mais surpreendente opulência de tesouros naturais do solo, o mais sábio governo do mundo, a população mais moralizada e pura, a constituição e as leis do Império religiosamente executadas, trabalho inteligente, a indústria esplêndida, abundância de ouro, profunda instrução em todos, contentamento geral, o céu na terra enfim...

Além de treze minutos: a visão do futuro... primeiro e de súbito imensa e compacta nuvem negra cobrindo todo o horizonte e logo através dela 
vivíssimo e penetrante raio de luz que me feriu e deslumbrou, que me fez recuar e cair por terra, quebrando em migalhas a luneta mágica de encontro a uma pedra! (LM, p. 157).

Durante os três primeiros minutos, o narrador apresenta uma visão negativa do país, decorrente do ceticismo que lhe dominara após as suas decepções - uma visão, entretanto, lúcida da realidade política e social. Depois dos três minutos, sob influência da luneta da visão do bem, temos uma perspectiva otimista e, ao mesmo tempo, falsa da administração pública. Quanto à visão do futuro, Macedo não fornece respostas claras: parece-nos que, apesar de a nação possuir um "horizonte negro", devido à maneira como vem sendo conduzida, ainda há esperança, simbolizada pelo raio de luz. Tal esperança, entretanto, encontra-se num futuro talvez longínquo e, portanto, não demove Simplício de sua vontade de morrer. Quem impede o suicídio do protagonista é o Armênio, cujas palavras apresentam uma chave alegórica para a leitura do romance:

- [...] não há aqui armênio nem Simplício.

- Então como nos chamamos?

- Eu me chamo Lição.

$-\mathrm{E}$ eu?

- Tu te chamas Exemplo. (LM, p. 160, grifo do autor).

A nosso ver, a explicação alegórica se sustenta à medida que, como procuramos mostrar em nossa análise, não apenas Simplício representa todos aqueles que são "escravos das ideias dos outros", como o seu irmão representa os políticos corruptos, a sua tia é uma personificação da hipocrisia religiosa e a sua prima uma representação das mulheres interesseiras. Além disso, o Reis seria uma personificação da ciência, enquanto o Armênio representaria a magia, a fantasia - e, por extensão, a literatura, cuja finalidade, apregoada pelos romancistas da época, seria ensinar o leitor, trazendo-lhe, portanto, "lições". Por conseguinte, seria função da literatura encorajar o bom-senso, simbolizado na terceira luneta 
ofertada a Simplício pelo Armênio - a qual, aliás, deveria ser ofertada "para uso dos membros do ministério e do governo do Brasil” (LM, p. 166), que careceriam dessa noção.

Nas palavras de Simplício, “ao menos porém a visão do bom-senso não me tornará nem cético, nem ludíbrio do mundo e dos homens" ( $L M$, p. 163). Com isso, Macedo parece ilustrar que a literatura não deve nem incitar o idealismo nem o ceticismo extremos, mas encontrar um ponto de equilíbrio, no que ele chama de "bom-senso". Essa terceira via, no entanto, não é vista como a mais fácil, uma vez que, se a sociedade não aprecia que lhe apontem seus defeitos, também não há garantias de que se vá conseguir mudá-la:

Pela visão do bom-senso reconhecerás, onde está o bem e o mal, e mil vezes não poderás aproveitar o bem, e livrar-te do mal. [...] Serás o censor de muitos e o reprovado de quase todos... [...] Os homens te condenarão contraditoriamente, como republicano e áulio, excêntrico e tolo, ateu e fanático, imoral e hipócrita, presumido e estúpido, santilão e demônio. ( $L M$, p. 163).

Assim, como afirma Juliana Maia de Queiroz, "por meio da intersecção entre elementos mágicos (a luneta; o Armênio), e outros da realidade cotidiana, Macedo não perde de vista sua opção pela composição ficcional embasada em uma crítica social” (2011, p. 132). Contudo, para procurar despertar a consciência do leitor, fazendo com que ele deixe de ser “escravo das ideias dos outros”, é necessário que a literatura também deixe de reproduzir as “ideias dos outros", isto é, as convenções romanescas. O romance macediano desobedeceria, portanto, os preceitos do subgênero fantástico, esboçados na "receita" ensinada por Horace Walpole no prefácio de $O$ Castelo de Otranto, referida por nós anteriormente, tais como: a ausência de "digressões ou descrições desnecessárias", a condução da narrativa "diretamente à catástrofe", de forma que a "atenção do leitor" nunca fique "relaxada", sendo o "terror" o “principal motor do autor" (Apud VASCONCELOS, 2007, p. 405). 
Como procuramos demonstrar em nossa análise, o narrador do romance de Macedo constantemente tece comentários sobre os mais diversos assuntos - a situação política, o caráter das pessoas, etc. -, expondo digressões que promovem um relaxamento da atenção do leitor, impedindo a fruição do enredo misterioso. Além disso, tal fruição é também evitada através da constante repetição das questões concretas da realidade social, que desviam o leitor da esfera fantástica, trazendo-o de volta ao mundo real. Já as descrições do sobrenatural são feitas de maneira tão minuciosa, com a sobreposição de tantos lugarescomuns do subgênero, que acabam por se mostrar artificiais e, até mesmo, cômicas. A proposta de A Luneta Mágica seria, dessa forma, conscientizar o leitor - e não assustá-lo -, através da comicidade, e não do terror. Nesse sentido, o romance macediano cumpre o seu papel - deixando de ser "escravo das ideias dos outros" -, não somente por desmascarar as aparências sociais, como também por se utilizar das expectativas de leitura do fantástico de maneira própria e deliberada. 


\section{Um outro romance histórico: heroísmo e nacionalismo em questão}

Tendo sido um dos subgêneros mais apreciados pelo leitor oitocentista, o romance histórico difundiu-se no mundo lusófono através das traduções de escritores como Walter Scott, Alexandre Dumas e Victor Hugo. Segundo Helena Carvalhão Buescu, em Portugal Scott começa a ser "referenciado e traduzido a partir de 1819, com nítida aceleração a partir de 1835, para se tornar, durante as décadas de 40 e 50, ao lado sobretudo de Hugo e A. Dumas (mas também de Frédéric Soulié), um dos polos referenciais da composição romanesca, sobretudo de matriz histórica" (1997, p. 357). De acordo com Castelo Branco Chaves, de 1836 a 1838 houve "pelo menos treze traduções" para o português de obras de Scott: "nas revistas e jornais literários de então, eram frequentes os artigos sobre o romancista escocês e as dissertações acerca do gênero por ele criado" (1979, p. 16).

Atraído pelo pitoresco da ambientação em tempos remotos, bem como pelas aventuras heroicas de capa e espada presentes principalmente na produção do escritor de $O s$ Três Mosqueteiros, o público consumia avidamente esse tipo de romance, cujo precursor em Portugal, também muito lido no Brasil, fora Alexandre Herculano, autor que começara a publicar na década de 1830 "as suas primeiras tentativas no gênero" nos periódicos $O$ Panorama e O Cronista (Cf. CHAVES, 1979, p. 16). Em Lendas e Narrativas (1851), Herculano defende a descoberta da nação e a valorização de suas raízes, a fim de construir o subgênero histórico em solo português: "Nós procuramos desentranhar do esquecimento a poesia nacional e popular dos nossos maiores: trabalhamos por ser historiadores da vida íntima de uma grande e nobre, e generosa nação, que houve no mundo, chamada nação portuguesa" (1986, p. 191). 
Da mesma forma, para Pinheiro Chagas em seus Ensaios Críticos (1866), “a pátria do romance histórico devera ter sido Portugal! [...] Poucas nações têm tido, como a portuguesa, uma existência tão aventurosa! Poucas têm na sua história tantos episódios dramáticos!” (1866, p. 51). Após exaltar os feitos de Portugal desde a Idade Média até o princípio do século XIX, que poderiam servir de rica matéria para o gênero, o autor descreve a geração de seus avós como "uma geração de gigantes, tal foi a grandeza épica dos feitos que então se praticaram" (1866, p. 52). Segundo ele, “em épocas assim fervem os assuntos do romance histórico. Um povo, cujas paixões estão concitadas em supremo grau, um povo heroico, exagerado, brutal na defesa da sua nacionalidade, é digno do estudo do romancista. Em cada peleja obscura, em cada emboscada há um episódio dramático” (1866, p. 54). Dutra e Mello, por sua vez, em seu prefácio a A Moreninha, publicado anos antes, em 1844, esboça opinião semelhante:

[...] o romance histórico nos tem dado primores, e muitas penas se criaram reputações continentais neste gênero, e à frente delas Walter Scott. Em Portugal tem ele prosperado com vigor: - e naturalmente um povo que se mergulha com saudade na recordação de suas passadas glórias; um país onde varões que emularam com a fortaleza das grandes personagens da antiguidade, imprimiram na história quadros sublimes de dedicação e valor; onde a cavalaria, os Mouros e os Árabes deixaram vestígios indeléveis, onde uma turma de literatos fortes nos sentimentos que dita o amor da pátria empunha agora a pena: este país, dizemos, não podia deixar de entrever no romance histórico a forma congênita e adaptada às ideias que nutre. (s/d, p. VIII).

Já na leitura do prefácio a Os Franceses no Rio de Janeiro: romance histórico (1870), de Manoel Duarte Moreira de Azevedo, encontramos ainda a mesma tendência, no Brasil dos anos 1870, de buscar o resgate de momentos gloriosos da História do país, com o intuito de realçar a sua grandeza e valorizar o seu povo: 
O desejo de ir tornando mais conhecidos certos episódios da história pátria, de ir lembrando fatos notáveis de que rezam as crônicas, esquecidas e empoeiradas nos arquivos, de emprestar ao povo os vultos venerandos dos seus antepassados, nos tem levado a buscar assunto para nossos romances nos monumentos históricos, nas memórias da pátria [...]. É de lá que vamos buscar inspiração para esses nossos trabalhos, a fim de caracterizarmos a índole, as tradições, os costumes do país em que nascemos e nos criamos, e registrar fatos que recordam glórias à pátria. (Apud SALES, 2003, p. 309).

Assim, em sua meta de ensinar o leitor sobre a História de seu país, o romance histórico pretendia assumir "a tarefa de vulgarizar o conhecimento e formar as massas populares: deste modo, o romance vem preencher uma função de utilidade social" (MARQUES, Ana, 2010, p. 113). Nas palavras de Arnaldo Gama, em Um Motim Há Cem Anos (1861), “a maneira de ensinar a história àqueles que não se aplicam aos livros, àqueles cuja profissão os arreda de poder fazer estudos sérios e seguidos, é o romanceá-la, dialogando-a, e dando vida à época, dando vida aos personagens, dando vida às localidades [...]” (Apud MARQUES, Ana, 2010, p. 113).

Como forma de valorizar a nação e promover o seu conhecimento, os romancistas investiam na caracterização espaço-temporal, através da descrição minuciosa da paisagem natural ou dos ambientes internos, bem como dos costumes e tradições da época retratada. De acordo com Maria de Fátima Marinho, a "constituição do ambiente" é um "fenômeno sem o qual é praticamente impossível pensar em romance histórico, tal como o Romantismo o concebia" (1992, p. 104), sendo então "importante aquilo a que vulgarmente se chama cor local" (1992, p. 105, grifo da autora). Por outro lado, como György Lukács explica, "Walter Scott nunca subestimou tais elementos pictóricos e descritivos. Utilizou-os até com tanta força que críticos superficiais viram nesse aspecto justamente o essencial de sua arte” (2011, p. 58) - críticos (e autores), é importante que se ressalte, não somente do século XX, mas também do Oitocentos. Pinheiro Chagas, por exemplo, é um dos que viram outras qualidades no escritor de Ivanhoé, a despeito da opinião corrente: para ele, "o gênio admirável de Walter 
Scott reproduzia com vivíssimo colorido os animados quadros do viver anterior da sua pátria"

(1866, p. 59); contudo,

[...] o que excitava o interesse, o que promovia o sucesso não era a verdade dos retratos, não era a ressurreição perfeita da época, era a aparição desses vultos extraordinários, para que seriam mesquinhas as telas da atualidade, era a narração dessas poéticas aventuras, a que não podem assistir os membros da geração prosaica, que vive neste século das conveniências. (1866, p. 60).

Assim sendo, o que Chagas julga ser essencial no romance histórico é o fato de nele podermos encontrar vultos extraordinários, ou seja, personagens que representam valores não mais encontrados na sociedade oitocentista. No entanto, como defende Lukács, apesar de na época ter sido interpretado dessa forma, "Scott não foi um romântico, um venerador ou um poeta elegíaco dos tempos passados” (2011, p. 74). Segundo ele, ao contrário, o escritor escocês

[...] procura o "caminho do meio" entre os extremos e esforça-se para demonstrar sua realidade histórica pela figuração ficcional das grandes crises da história inglesa. Essa tendência fundamental de sua figuração se expressa de imediato no modo como ele inventa a trama e escolhe a personagem principal. O "herói" do romance scottiano é sempre um gentleman inglês mediano, mais ou menos medíocre. (2011, p. 49).

Com isso, na visão de Lukács, o importante para escritores como Scott é

[...] desvelar de maneira figurada as imensas possibilidades humanas e heroicas que se encontram latentes no povo e emergem à superfície "de repente", com fúria monstruosa, sempre que uma grande ocasião se apresenta, sempre que há uma comoção profunda na vida social ou mesmo na vida pessoal mais imediata. A grandeza dos períodos de crise da humanidade repousa, em grande medida, no fato de que tais forças ocultas permanecem latentes no povo e só necessitam de uma ocasião que as deflagre para vir à tona. [...] O que queriam mostrar é que as possibilidades desse salto humano, desse heroísmo, estão presentes nas massas populares e muitos membros do povo vivem tranquilamente sua vida, sem nenhum salto, 
apenas porque não passam por uma experiência que leve a tal concentração de forças. Precisamente por isso é que as revoluções são as grandes épocas da humanidade, porque nelas e por meio delas ocorrem os movimentos de ascensão das capacidades humanas. (2011, p. 72).

Sendo assim, de acordo com a leitura de Lukács, em Walter Scott o herói é o homem médio comum, responsável pelas transformações sociais, erigidas em tempos de crise. O teórico critica a forma como a figura do herói foi construída durante o século XIX nos romances históricos românticos, que se distanciam do retrato scottiano: "as grandes personagens históricas da época são os heróis de seus romances e, em conformidade com o 'trabalho da fantasia popular', eles são representados por uma série de anedotas de caráter pitoresco e acompanhados de reflexões moralistas" (2011, p. 100). O uso desse propósito moral na composição do herói é defendido, por exemplo, nas Lições Elementares de Eloquência Nacional (1834), de Francisco Freire de Carvalho:

O que porém torna mais digno de recomendação este mesmo Gênero de composições [o romance histórico], é a pintura de caracteres, conformes à Natureza, desenhados por um modo vivo e atrevido, e sempre tendentes nas suas feições a inspirarem sentimentos de bondade, de humanidade, e em geral a maior pureza de costumes, por meio de cuja pintura sejam conduzidos os seus leitores a tudo, quanto é louvável, deixando-lhes na alma impressões úteis, decentes e virtuosas. (1856, p. 296).

Como explica Ana Maria Marques, sobre os personagens dos romances históricos portugueses, "quanto aos heróis, não podemos falar de semelhanças com o modelo escocês: trata-se agora de verdadeiros heróis românticos, dominados pelo excesso das paixões que não conseguem controlar e impelidos desesperadamente para um final trágico" (2010, p. 104). Segundo Helena Buescu, Alexandre Herculano e seus seguidores possuem um "intuito ideológico" que fazem "convergir no herói a particularização de uma causa coletiva, que aliás não faz elidir o projeto pessoal (e passional) que também o define como herói” (1997, p. 357). 
O típico romance histórico romântico centrar-se-ia no período medieval porque é nele que se “encontra a conformação dos grandes valores e dos grandes ideários nacionais, corporalmente assumidos através de várias personagens, de entre as quais avulta o herói” (1997, p. 357).

O mesmo se poderia dizer do subgênero cultivado no Brasil, representado por $O$ Guarani (1857), de José de Alencar: “[...] é um romance histórico que busca enraizar num medievalismo ideal os fundamentos da nacionalidade [...]; o seu propósito implícito era conferir nobilidade e prestígio às origens brasileiras" (MARTINS, W., 1977b, p. 65-66, grifo do autor). De acordo com Sandra Vasconcelos, “Alencar [...] infla seus heróis, atribui-lhes uma envergadura que os alça sobretudo à condição de personagens romanescas, superiores por sua força, coragem e integridade moral, em tudo e por tudo mais potentes que os comuns dos mortais" (2008, p. 23).

Para Pinheiro Chagas, o romance histórico teria sofrido um processo de degeneração durante o século XIX, decaindo até chegar a As Aventuras de Rocambole (18571870), de Ponson du Terrail ${ }^{1}$. Segundo o crítico, a partir de Walter Scott, o subgênero teria sido continuado por Alexandre Dumas, "gênio extraordinário, que o mercantilismo reduziu a proporções menos colossais do que as que poderia ter" (1866, p. 60), que teria tomado "por tema de infinitas variações a índole das diferentes épocas, que ele não estudava mas adivinhava" (1866, p. 60), tendo bordado "na tela da história ficções a qual mais engenhosa, embelezadas com quantos lavores e matizes lhe proporcionava a sua opulenta fantasia, e o seu engenho verdadeiramente descomunal. Esta feiticeira degeneração do romance histórico foi acolhida com dobrado entusiasmo do público" $(1866, \text { p. } 60)^{2}$.

\footnotetext{
${ }^{1}$ Sobre Ponson du Terrail, conferir Folhetim: uma história (1996), de Marlyse Meyer, que analisa As Aventuras de Rocambole com mais simpatia do que os críticos oitocentistas. Esse conjunto de romances é também conhecido como Os Dramas de Paris.

${ }^{2}$ Por outro lado, Maria Lúcia Dias Mendes considera tais características de Dumas como positivas, uma vez que o autor "dá vida aos acontecimentos criando personagens secundárias que agem na História, buscando segredos de alcova, mexericos de outros tempos, enfim, recriando a atmosfera da época retratada" (2002, p. 39), criando, assim, "uma História que, sendo mais cheia de aspectos cotidianos, consegue ser mais 'real' do que aquela que se lê em livros tradicionais de historiografia, exatamente como desejava o público de sua época" (2002, p. 39).
} 
Como explica Maria Lúcia Dias Mendes, Dumas "ficava muito distante do nacionalismo que movia o 'bardo escocês' [...]. Na década de 1840 [na França], já não era mais uma questão de afirmação ou legitimação política e artística [...], mas sim de um romantismo mais bem comportado, "um romantismo de salão elegante"' (2002, p. 40-41, grifo da autora). As aventuras de capa e espada passaram a agradar mais do que o resgate da História gloriosa da nação: o entretenimento passou, assim, a ser colocado em primeiro lugar. Nas palavras de Chagas,

Depois o romance histórico foi continuando a resvalar pela perigosa ladeira, para onde o impelira Dumas. [...] O que importava a degeneração aos leitores, se as peripécias se iam tornando cada vez mais impossíveis, e por conseguinte mais curiosas? Às fantasiadas mas fantasiosas narrações de Dumas sucediam as lucubrações abstrusas de espíritos enfermos. Hoje a imaginação assusta-se ao contemplar o caminho percorrido pelo romance histórico, a imensa distância que separa Ponson du Terrail de Walter Scott. (1866, p. 61, grifo do autor).

Sampaio Bruno, por sua vez, em A Geração Nova (1886), ao apontar os principais romancistas históricos que teriam influenciado os autores portugueses, mostra uma visão menos deletéria do subgênero, ainda que reproduza o mesmo juízo de Chagas sobre As Aventuras de Rocambole:

Como sugestão próxima, tinham os românticos a solicitar-lhes o engenho o êxito extraordinário que, no princípio do século, haviam alcançado as novelas de Walter Scott. Victor Hugo mete os ombros ciclópicos à empresa e Nôtre-Dame-de-Paris surge como um padrão eterno, de que decorrem as laboriosas investigações, hoje esquecidas, do bibliófilo Jacob, e esse sombrio Cinq-Mars, de Alfred de Vigny, modelo de que o corolário é a quase secura de Mérimée, até que o gênero, de escalão em escalão, se vai esgotando, a começar na verve prodigiosa do velho Dumas, a acabar na ignorância ingênua de Ponson du Terrail. (1886, p. 14, grifo do autor).

Assim, o romance histórico parece ter passado por várias "fases", que, em

Portugal, foram divididas pela crítica numa primeira, de tema medieval, representada por $O$ 
Monge de Cister (1848), Eurico, o Presbítero (1844), O Bobo (1843) e os contos de Lendas e Narrativas (1851), de Herculano, O Arco de Sant'Ana (1845-1850), de Almeida Garrett, Ráusso por Homízio (1842-1843) e Ódio Velho Não Cansa (1848), de Rebelo da Silva ${ }^{3}$ (Cf. MARQUES, Ana, 2010, p. 96-97); e numa segunda, em que se passa a preferir "temas mais atuais e épocas menos recuadas [...]. Começa a desvanecer-se o interesse pelo medievalismo [...], e a obra de Rebelo da Silva reflete claramente essa mudança: o século XVIII e as invasões francesas passam, agora, a ser épocas repetidamente convocadas” (MARQUES, Ana, 2010, p. 97).

Já no Brasil, destacam-se Gonzaga ou a Conjuração de Tiradentes (1848) e Recordações dos Tempos Coloniais (1856), de Teixeira e Sousa, O Aniversário de Dom Miguel em 1828 (1839) e Jerônimo Corte Real (1865), de João Manuel Pereira da Silva, Padre Belchior de Pontes (1876-1877), de Júlio Ribeiro, Maurício ou Os Paulistas em São João Del Rei (1877), de Bernardo Guimarães, e Os Índios do Jaguaribe: história do século XVII (1862), Um Casamento no Arrabalde (1869), O Cabeleira (1876), O Matuto (1878) e Lourenço (1881), de Franklin Távora (Cf. BASTOS, s/d), além de várias obras de José de Alencar, tais como o já referido O Guarani (1857), Iracema (1865), As Minas de Prata (1865-1866), Guerra dos Mascates (1871-1873) e Ubirajara (1874).

Dessa forma, procuramos esboçar aqui algumas das tendências do romance histórico que teriam se difundido nos mercados editoriais português e brasileiro durante o século XIX. Através da leitura principalmente de críticos da época, procuramos apontar quais seriam as características do subgênero mais valorizadas no Oitocentos e, portanto, mais apreciadas pelos seus leitores - características com as quais Camilo e Macedo irão dialogar em suas obras, questionando-as ou, às vezes, ignorando-as, expondo uma outra visão sobre a

\footnotetext{
${ }^{3}$ Ressalvamos que, como bem lembra Ana Marques, alguns críticos já apontaram que Herculano, Garrett e Rebelo da Silva questionam e ironizam certas convenções do romance histórico em algumas de suas obras: "Mas Garrett vai mais longe nesta desconstrução do romance histórico, parodiando as convenções de um gênero tão popular naquela época" (2010, p. 170), "mostrando, simultaneamente, o profundo conhecimento das regras desse mesmo gênero e das expectativas do seu público" (2010, p. 186).
} 
nação e sua História, propondo não somente a crítica social, mas a crítica aos modelos literários em voga. 


\subsection{O Demônio do Ouro e um brasileiro de Minas chamado Joaquim José da Silva Xavier}

O Demônio do Ouro: romance original, de Camilo Castelo Branco, foi publicado em dois tomos: o primeiro em 1873 e o segundo no ano seguinte (Cf. CABRAL, Alexandre, 1988, p. 286). Como, comparativamente a outros romances camilianos, não foi um grande sucesso na época - teve somente duas edições durante o século XIX (Cf. MARQUES, H., 1925, p. 195) -, nem foi muito lida durante o século XX, a obra acabou sendo esquecida pela crítica camilianista, que não costuma incluí-la entre os romances históricos do autor. Pinheiro Chagas, contudo, no prefácio à edição publicada em 1890 de Amor de Perdição, faz menção a ela:

$\mathrm{O}$ romance e a narrativa histórica de tal modo o absorvem que se diria que a sua aspiração é rivalizar com Walter Scott. É o Regicida, a Filha do regicida, o Demônio do ouro, a Caveira da mártir, o Olho de vidro, o Santo da montanha, o Judeu, o Senhor do Paço de Ninães, a Luta de gigantes e quantos outros ainda. (Apud MOUTINHO, 2005, p. 76).

Ao citar O Demônio do Ouro entre as narrativas históricas camilianas, Chagas mostra que a obra foi recebida como um exemplar deste subgênero na época de sua publicação. Nem poderia ser diferente, uma vez que o seu enredo se passa, na primeira parte do romance ${ }^{4}$, durante o século XVIII - período usualmente retratado pelos romancistas históricos portugueses da "segunda fase", como explicamos anteriormente. Além disso, alguns personagens fictícios da trama interferem num fato real da História - a Inconfidência

\footnotetext{
${ }^{4}$ O Demônio do Ouro é divido em duas partes, a primeira ambientada na segunda metade do século XVIII, e a segunda no início do século XIX, com enredo bastante diverso e com outros personagens - os herdeiros de um dos protagonistas da primeira parte. Como o nosso objetivo nesta pesquisa é trabalhar com o romance histórico, acreditamos ser mais conveniente analisar somente a primeira parte da obra. Dessa forma, está implícito que, sempre que nos referirmos a esse romance neste subcapítulo, estaremos nos referindo à sua primeira parte.
} 
Mineira -, interagindo com figuras históricas como Tiradentes e os poetas árcades brasileiros 5

Sendo assim, nessa obra Portugal é apenas um de seus espaços, o que nos chama a atenção, tendo-se em vista que o típico romance histórico romântico procurava, sobretudo, o resgate e a valorização da História do próprio país. Ao contrário, encontramos no romance camiliano uma rede de deslocamentos tão rica que chega a surpreender o leitor contemporâneo, habituado à sua imagem de escritor das "províncias nortenhas no seu tempo", conforme as palavras de Saraiva e Lopes (1996, p. 779). Nele, o enredo se passa em Portugal, Londres e Brasil, sendo também citados outros países como Índia, Canadá, Irlanda, Itália, Holanda e Alemanha.

O início da trama é semelhante ao de muitos romances do autor. Trata-se da história de Manuel Vieira, um menino órfão que é adotado por uma família pobre da Póvoa de Lanhoso. Quando cresce, o rapaz sai à procura de trabalho e consegue um emprego de caixeiro numa casa comercial que negociava a importação e exportação de vinho e algodão, pertencente a uma família de ingleses - os irmãos Bearsley -, com sedes no Porto, Londres e Bengala. Com isso, o fato de as ações se passarem em vários lugares mostra que o foco do autor não está na promoção da História de Portugal. Logo no primeiro capítulo, aliás, o paradigma do romance histórico é colocado em xeque pelo narrador numa longa passagem em que descreve - com intuito paródico - os pormenores históricos em torno de monumentos da Póvoa de Lanhoso, questionando ironicamente o seu estatuto de verdade:

Sobranceando a Póvoa, negrejava o castelo de Lanhoso, ereto em rocha, recortado de ameias, lardeado de bastiões, golpeado de seteiras, ali perpetuado, rebatendo as injúrias de nove séculos, imagem, símbolo da raça forte que, ao passar por lá, empedrou um dos seus gigantes, como vigia eterna das gerações que se desforçam a camartelo da sua vergonhosa

\footnotetext{
${ }^{5}$ Embora Camilo tenha escrito outros romances históricos, optamos por trabalhar aqui com O Demônio do Ouro devido ao fato de a obra tratar de um episódio importante da História do Brasil, sendo do interesse de nós, leitores e pesquisadores brasileiros, resgatá-la de sua obscuridade.
} 
afeminação [...]. Lá foi que D. Rodrigo Gonçalves Pereira de Berredo, esposo atraiçoado por um frade de Bouro, pegou o fogo pelos quatro ângulos, assando a esposa, o frade, os criados, as bestas, tudo, criminosos e inocentes, desde a adúltera até o frade, o frade talvez inocentíssimo, embora o genealógico D. Pedro, conde de Barcelos, mentiroso como todos os linhagistas, referindo o caso, duvide da inocência do monge. $\left(D O^{6}\right.$, p. 333$)$.

Ao referir-se ao pai adotivo de Manuel Vieira, o narrador afirma que "estas referências históricas decerto não preocupavam o ânimo de João Veríssimo. Os monumentos da velha Galiza, aquelas relíquias dos netos de Pelágio não lhe preponderavam tanto no espírito como os seis anos da criança que não tinha mãe, e não sabia a quem dar nome de pai” (DO, p. 333). Com isso, ao mesmo tempo que critica a inutilidade e a falta de relevância, a seu ver, do resgate da História - e, consequentemente, do romance histórico - para o povo, Camilo evidencia que a crítica social está no centro de sua obra.

O patrão de Manuel é retratado pelo narrador como um inglês honrado e bom, que ajuda o rapaz a subir na carreira e enriquecer, dando-lhe salários proporcionais à competência e honestidade do caixeiro. Seu caráter é descrito logo no início, quando o protagonista precisa escolher entre a proposta de emprego do inglês e a de um comerciante português: "Desconfiei que o português queria enganar o outro, por isso me agraciei menos dele; e também porque o português me falou com modos brutais, e o outro [o inglês] com bondade, tratando-me como se eu estivesse bem vestido" ( $D O$, p. 360). No momento em que o narrador contrapõe o honrado comerciante inglês ao desonesto português, vemos um denegrimento da imagem do povo lusitano, em vez do ufanismo usualmente apregoado pelos romances históricos.

Além disso, o enredo mostra que em Portugal o menino pobre sofrera preconceito ao pedir esmolas nas ruas e, quando jovem, tem dificuldade de arranjar emprego pela falta de recomendações. Quando a mãe adotiva de Manuel sugere enviá-lo para Braga ou para o Porto para procurar trabalho, o seu marido responde: “Quem conheces tu lá, mulher! [...] a quem

\footnotetext{
${ }^{6}$ Ao longo deste trabalho adotaremos a sigla $D O$ sempre que citarmos o romance $O$ Demônio do Ouro, de Camilo Castelo Branco. As citações são retiradas do volume VII das Obras Completas (1987).
} 
havemos de o mandar? Tu cuidas que Manuel chega a qualquer dessas cidades, e, sem proteção nem recomendação de ninguém, encontra patrão que o aproveite?” ( $D O$, p. 354). É sua filha quem sugere a solução: "Peço ao padrinho das Agras que me dê uma carta para alguém de Braga ou do Porto" (DO, p. 354). Dessa forma, temos que a única saída para os mais pobres, em Portugal, é depender da proteção dos mais ricos, dos grandes proprietários, numa relação de favor que muito se assemelha aos vínculos de dependência encontrados no Brasil imperial. Nesse sentido, Camilo não mostra um pendor nacionalista, mas antes uma crítica à perversa sociedade portuguesa, movida pelas aparências e por práticas como o apadrinhamento, que tolhem as oportunidades dos menos favorecidos.

Manuel, no entanto, não precisou recorrer a esse estratagema para conseguir o seu emprego de caixeiro, uma vez que encontrou o patrão inglês por acaso, ao intervir numa discussão em que este estava sendo enganado pelo comerciante português. Indo trabalhar na Inglaterra, o rapaz consegue ser respeitado e valorizado pela sua competência, acabando por ganhar muito dinheiro e ser bem-sucedido. Parece-nos que, aqui, Camilo aproveita-se do mito do self-made man, muito difundido nos romances ingleses do século XVIII, como explica Sandra Vasconcelos: "o romance inglês é um forte instrumento na propagação da ideia de que há lugar para todos no mundo capitalista e que a ascensão social é uma possibilidade aberta para quem quer que se esforce por ela" (2005, p. 208).

Sabemos que na Inglaterra, como afirma Eric Hobsbawm, "as carreiras do mundo burguês estavam de fato abertas ao talento, mas as famílias com um certo grau de educação, propriedade e ligações sociais, entre outras, certamente começavam com uma enorme vantagem relativa" (2007b, p. 335). Entretanto, se tal fato dificultava a ascensão social dos mais pobres, não era um impeditivo: "Em que medida eram [os trabalhadores] recémpromovidos a partir das classes mais baixas? Não em grande número, embora em teoria nada impedisse a sua ascensão social” (2007b, p. 334). Em Portugal, por outro lado, segundo 
Camilo, a proteção de um grande proprietário era obrigatória para conseguir um emprego, tanto no próprio país, como no Brasil - cujos comerciantes também exigiam dos portugueses imigrantes cartas de recomendação -, o que explicita as diferenças entre os centros e as periferias, onde os mitos do capitalismo nem de longe se verificam.

Assim, Manuel Vieira muda-se para Londres, onde acontece boa parte da história. Quando acontece um crime - um dos funcionários da casa comercial, Johnson Fowler, falsifica documentos e comete um assassinato com o intuito de roubar os irmãos Bearsley -, há boatos de que o assassino teria fugido para o Canadá, mais um país que entraria na rota de deslocamentos atlânticos traçada por Camilo: "as indagações da polícia descobriram que ele, dias antes, havia tirado passaporte para o Canadá” (DO, p. 390). Fowler, na verdade, acaba fugindo para o Brasil, e a sua fuga, com a apropriação de identidades falsas, mostra a intensa relação entre vários países europeus:

[...] encontrou-se registrado o passaporte de um Gower, padre católico irlandês, que ia à Itália [...]; descobriu-se que ele havia embarcado em navio holandês com destino a Pernambuco, posto que o consignatário da casa nos Países Baixos dissesse que o passageiro lhe apresentara o seu passaporte em que se intitulava George Jonathan Holland, filósofo de profissão, natural de Rosenfeld, no ducado de Wurtemberg, casado com Maria Van Hooft, natural de Middelbourg. (DO, p. 400).

Somente neste parágrafo temos citadas a Irlanda, Itália, Holanda e Alemanha esta através do filósofo, que realmente existiu, Georg Jonathan Holland (1742-1784), que o narrador camiliano não deixa de satirizar: "o infame [Fowler] passara deleitosamente a copiar assinaturas, não poupando a do sábio Jonathan, que, àquela hora, estava talvez lucubrando na sua adiposa obra intitulada Reflexões Filosóficas sobre o Sistema da Natureza” (DO, p. 400, grifo do autor). Este, aliás, não é o único filósofo setecentista que revive na obra de Camilo: os franceses também aparecem, quando o narrador apresenta o pretendente da filha de Bearsley como o "filho natural do conde de Chesterfield, nascido em França de uns famosos 
amores que o douto lorde, amigo de Voltaire e Montesquieu, lá contraíra em anos juvenis” (DO, p. 379).

Filipe de Chesterfield, um típico aristocrata inglês e "futuro conde" (Cf. DO, p. 379), é prometido a Ana Bearsley, que também era requisitada pelo vilão Johnson Fowler. Antes de roubar a casa comercial, Fowler convence o tio dela, seu patrão, de que o rapaz queria se casar com a moça por interesse, uma vez que estaria imerso em dívidas, apresentando-lhe uma letra falsificada, em nome de Filipe: "Acusou-o de pródigo, de esbanjador de seus bens, e futuro dissipador dos haveres de uma família [...], asseverando que ele se dava pressa em casar porque estava perto o dia de pagar uma letra, já reformada no banco, e cumpria que o pagamento improrrogável saísse do cofre dos Bearsley" (DO, p. 379380). Ao ser confrontado pelo tio de Ana com a letra falsa, o rapaz exaspera-se:

- Eu não escrevi esta assinatura; pela minha honra o juro! E, se não puder provar que a minha assinatura foi falsificada, matar-me-ei!

As contorções de assombro e cólera eram mais persuasivas que o protesto do suicídio em um país onde o spleen matava mais gente que o receio da desonra. (DO, p. 381, grifo do autor).

Neste trecho, o narrador camiliano ridiculariza a "misantropia inglesa, doença deplorável que o suicídio nos dá a perceber como a terribilíssima crise da saciedade dos prazeres" (DO, p. 405), típica dos românticos que viam na morte a única saída, desvelando a convencionalidade do spleen, uma vez que a ameaça de Filipe de se matar não comovera o seu interlocutor. Ressentido por ter sido desacreditado pelos Bearsley, o fidalgo parte numa viagem para o Brasil, a fim de esquecer o amor contrariado: "por 1774 sabemos que ele estava em Lisboa, e em 1775 no Rio de Janeiro, onde embarcou para o Grão-Pará” ( $D O$, p. 406). Coincidentemente, numa reviravolta folhetinesca, Filipe acaba desvendando nesse último local o paradeiro do criminoso, que havia se hospedado na casa de sua meia-irmã. 
A aventura se passa, então, no Pará, às margens do rio Amazonas, cenário que serve de ensejo para que o autor se utilize da imagem estereotipada do Brasil como um país de "robustos índios" (Cf. DO, p. 409) e florestas virgens - o que agradaria ao seu leitor habituado às narrativas de viagem em terras americanas, escritas por viajantes europeus e muito lidas na época ${ }^{7}$. Além disso, tal imagem também está presente em Gonçalves Dias e José de Alencar, autores já conhecidos no Portugal da década de 1870, e com os quais Camilo concorria no mercado editorial brasileiro. A paisagem amazônica é retratada pelo narrador camiliano seguindo esses modelos difundidos:

As margens daqueles rios, artérias pujantes em que arfam as ondas do Amazonas, são ensombradas de árvores giganteias, que fazem tristeza e pavor. O homem ali vê-se tão pequeno, tão verme a pascer-se nos sucos de seu próprio coração, que chega a sentir enojo das quimeras por onde se quis avantajar ao comum de sua espécie. E aquele que ali chegou, ido das cidades onde toda a grandeza, exceto a da virtude obscura, é convencional e fantástica, esse [...] entrou-se de amargura imensa, e, em meio daquelas vidas colossais, da ave enorme e da árvore que topeta as nuvens com as suas franças, cuida que à volta de si tudo é o infinito vácuo da morte. As solidões majestosas são essas em que o homem verte lágrimas humildes sobre os andrajos da sua púrpura de rei da criação. Ainda, se nos ouvidos da alma lhe rumorejam os mil hinos daqueles silêncios - se por de sobre as copas das florestas lhe vai o espírito desferindo voo em demanda de Deus -, a sua alegria pode ser grande como a do eremita de Ístria que nas solidões profundas encontrava a paz, as lágrimas e a morte, que tanta crueza tem se a meditamos sem a desejarmos. (DO, p. 410).

No entanto, baseados no que comumente encontramos na produção camiliana, é possível aqui duvidarmos da sinceridade do narrador. Toda essa prolixa e desnecessária descrição, que não se relaciona com a ação, pode ser justamente uma paródia a esse tipo de narrativa. Isso fica mais evidente quando, páginas adiante, o narrador descreve ironicamente a cena em que Johnson Fowler é encontrado pela polícia, convocada por Filipe: “tomando três soldados [...], desceu à margem do rio, onde Johnson, com inglesa excentricidade, se comprazia de acalentar os sonos ao rouquejante piar das arapongas e guirapongas, dos

\footnotetext{
${ }^{7}$ Tratamos das narrativas de viagem no capítulo 4.
} 
galeirões, e guarases e japis, e outras aves de nomes igualmente poéticos" (DO, p. 415). A sucessão de termos indígenas da fauna brasileira é aqui claramente inserida de maneira artificial, sem relacionar-se com a ação, evidenciando o intuito de Camilo de parodiar a temática indianista utilizada pelos escritores brasileiros.

Nessa abordagem, Fowler é supostamente morto por um dos índios que acompanhavam os policiais - que "desfechou a espingarda contra a testa de Johnson, salpicando de sangue o guadalmecim que tapizava as paredes da barraca" (DO, p. 416) -, e seu corpo é jogado no rio. O vilão, no entanto, fingira-se de morto, acabando por escapar e indo para o Maranhão, acompanhado da amante brasileira. Em seguida, Camilo dedica um capítulo inteiro para tratar da biografia da amante de Fowler e sua irmã, mulheres de vida dissoluta, com o intuito de parodiar os relatos históricos:

Declinarei de mim a imputação de aleivosia assacada à memória das Senhoras Catânias, trasladando das "Memórias" de D. Fr. João de S. José Queirós algumas linhas biográficas daquelas damas.

"A 2 de Janeiro (vem historiando o bispo em linguagem que tresanda a folhetim, pág. 175) descemos pelo mesmo Garapé (freguesia de S. Miguel do Guamá) [...]. É caso que poderá servir de instrução ao leitor (de instrução! credo!). Na cidade de Belém ficaram órfãs de pai duas moças. Chamemos Laurentina uma, e Nise a outra. (Honrada pseudonimonia!)". (DO, p. 441, grifo do autor).

Ao inserir seus comentários jocosos, entre parênteses, na suposta transcrição das "Memórias" de um certo Fr. João de S. José Queirós, o narrador camiliano ridiculariza o intuito didático dos relatos históricos - afinal, a vida de tais mulheres não teria nada a ensinar aos leitores. Além disso, há também a interpolação de notas de rodapé, comentando os erros gramaticais do tal Frei, contribuindo para o rebaixamento desse tipo de narrativa: "Não se siga, nesta passagem, a gramática do sábio monge de S. Bento" (DO, p. 441, grifo do autor).

Voltando à diegese, o narrador afirma que no Maranhão Fowler adota a identidade de "um estadista que estuda as confederações, repúblicas e impérios americanos" (DO, p. 
448), que "dizia conhecer de $t u$ Washington, Boston e outros corifeus da independência [dos Estados Unidos]" ( $D O$, p. 449, grifo do autor). Tal identidade lhe serve para fazer amizade, durante a viagem, com ninguém menos que "um brasileiro de Minas, chamado Joaquim José da Silva Xavier - mais notório pela alcunha de "Tiradentes"' (DO, p. 448), que lhe confidencia "planos políticos do maior melindre, [...] instando-o a residir temporariamente em Minas Gerais" (DO, p. 449). O personagem camiliano é, assim, colocado ao lado de figuras históricas da Inconfidência Mineira: “Apresentado como homem de Estado da Grã-Bretanha, insinuou-se na estima do celebrado republicano José Alves Maciel de S. João d'El-Rei, dos três poetas Tomás António Gonzaga, Inácio José de Alvarenga Peixoto e Cláudio Manuel da Costa" (DO, p. 449).

Sendo "depositário dos segredos da conjuração" (Cf. DO, p. 449), Fowler acaba sendo o responsável direto pela condenação de Tiradentes e seus companheiros, e não Silvério dos Reis, como a História registrou. Isso porque, segundo o narrador, Silvério dos Reis teria somente delatado ao governador a amizade de Fowler com os conjurados (Cf. DO, p. 450), e contado que o inglês era "casado com uma sedutora paraense, que alguém reputava amante de Silva Xavier" (DO, p. 450). Ao ter sido interrogado pelo governador - que lhe revela a traição de sua mulher com Tiradentes (Cf. DO, p. 450) -, o vilão teria denunciado "que o brado da revolta devia estalar em Vila Rica, e ele visconde de Barbacena estava votado à morte [...]. Depois nomeou os conjurados [...]. E [...] obrigou-se a espiar o restante processo da revolta, se ao governador conviesse o segredo das revelações feitas" (DO, p. 451).

Ao misturar a História e a ficção, Camilo desmerece a traição de Silvério dos Reis, colocando como motivo principal para o fracasso da Inconfidência Mineira um fato prosaico: Fowler teria delatado Tiradentes pelos ciúmes de marido traído. Aliás, retratar Tiradentes como um homem mulherengo também é uma forma que o autor encontra de rebaixar uma personalidade histórica tida como herói no Brasil. As figuras históricas 
portuguesas, bem como a própria História de Portugal, por sua vez, também não são poupadas da crítica irônica tecida pelo narrador camiliano, que lamenta a violência da política de expansão territorial empregada pelo seu país:

Dizem que a árvore da independência do Brasil hauriu seiva daquele sangue [de Tiradentes]. Certamente, Portugal, ali e em toda a terra e mar onde arvorou a bandeira de Cristo, espontada em lança de bárbaros, foi inconsciente instrumento da civilização dos seus escravos. A rainha que assinou a condenação da lenta morte de Gonzaga, de Alvarenga e Cláudio Manuel da Costa é uma que os livros históricos das escolas denominam $a$ piedosa. (DO, p. 454, grifo do autor).

Além disso, é interessante notarmos que o Brasil costuma ser apontado na ficção portuguesa oitocentista - e, principalmente, na produção de Camilo - como um espaço econômico, de enriquecimento. Como explica Paulo Motta Oliveira, "na ficção camiliana o Brasil está totalmente integrado ao universo econômico português" (2012, p. 6), sendo "para esses personagens um espaço de enriquecimento, único possível para uma grande classe de desprivilegiados, de filhos bastardos a pobres camponeses das províncias e aldeias, que não encontram saídas em seu próprio país" (2012, p. 6). No caso de O Demônio do Ouro, trata-se do espaço em que ocorrem as peripécias mais emocionantes, a aventura - um espaço em que se encontram plasmados os lugares-comuns do romance histórico romântico, sobretudo a tradição dumasiana das aventuras de capa e espada, continuada por autores como Ponson du Terrail. A presença do Brasil como um espaço da aventura agradaria, dessa forma, ao leitor brasileiro, importante consumidor da obra de Camilo, e ao público de aquém e além-mar que apreciava o subgênero.

Por fim, fica-nos a pergunta: qual seria o herói deste romance? O personagem que mais aparece na narrativa é Johnson Fowler, um ladrão sem nenhum caráter, lembrando-nos Rocambole, de Ponson du Terrail. De acordo com Marlyse Meyer, 
Pode-se então dizer que o termo rocambolesco não é somente um estereótipo definindo uma aventura descabelada, mas designa precisamente aquele conjunto de ações, conspirações, planejamentos por uma cabeça muito fria, de inteligência ímpar, para a urdidura da trama que permite, utilizando todos os talentos, todos os vícios, subornando, ameaçando, lançando mãos do crime e da sedução, alcançar a qualquer preço, sem o menor escrúpulo, desconhecendo até a menção da moral, a única meta que interessa: o dinheiro. (1996, p. 120, grifo da autora).

É interessante notarmos que uma grande parte de O Demônio do Ouro poderia se chamar As Aventuras de Johnson Fowler, em referência à obra de Ponson du Terrail, uma vez que os episódios têm muito de rocambolesco. Para agradar ao leitor que apreciava as peripécias “cada vez mais impossíveis” de Rocambole, nas palavras de Pinheiro Chagas (Cf. 1866, p. 61), Camilo introduziu em seu romance um personagem criminoso, que viaja por vários países, metendo-se em episódios históricos como a Inconfidência Mineira. No entanto, trata-se de um personagem inglês, estrangeiro - o que nos faz pensar que talvez o autor tivesse consciência quanto à sua estratégia de importação dos moldes folhetinescos.

Filipe de Chesterfield, um nobre de origem francesa que vive na Inglaterra, seria o personagem que mais se aproximaria da figura do herói romântico, pois captura o vilão Fowler em meio a um cenário exótico e pitoresco - a selva amazônica - tudo pela honra e pelo amor à bela donzela Ana Bearsley. No entanto, como vimos anteriormente, a descrição desse cenário é parodiada das narrativas de viagem e de temática indianista, a partir do contraste entre um tom grandiloquente e um tom cômico, apontando o que esse tipo de descrição teria de ridículo. Esse herói, por outro lado, pouco aparece na história, além de não ser português e, portanto, não representar os valores da nação lusitana. Parece-nos, assim, que Camilo se utiliza desse personagem - como Fowler, também importado - para inserir a aventura heroica no romance, um elemento que muito atraía o leitor oitocentista, sedento por façanhas à la Alexandre Dumas. 
Manuel Vieira, apesar de perder a posição central no enredo a partir da metade da narrativa - ainda que a diegese continue estruturada em sua trajetória -, é mostrado no início de O Demônio do Ouro como o seu protagonista e, nas palavras do narrador, "é o herói do romance" ( $D O$, p. 398). Porém, o personagem nada teria de semelhante com os gloriosos heróis do modelo de romance histórico em voga, pois leva uma vida extremamente prosaica e não se envolve em nenhuma aventura - o que talvez justifique o fato de ter sido colocado em segundo plano na ação, em prol de personagens mais interessantes e romanescos, como Fowler e Filipe. Como o narrador camiliano afirma, "o montanhês de Lanhoso como que ainda conservava o selvagismo nativo, e certo não podia ser personagem de romance que levasse o fito posto em espantar pessoas tão pouco espantadiças como hoje em dia são os consumidores destes livros” ( $D O$, p. 398). Aparentemente, Manuel Vieira não é digno de representar o ideário heroico da nação portuguesa - a não ser que o romance estivesse querendo mostrar que Portugal justamente careceria desse tipo de heroísmo. A partir desse questionamento da figura do herói, o autor apresenta uma visão mais lúcida da História, que teria sido construída pelo homem comum, que luta pela sobrevivência e - na Idade Contemporânea - pela ascensão financeira.

Em O Demônio do Ouro, Manuel Vieira também é um homem “mediano" e “medíocre", assim como o herói scottiano (Cf. LUKÁCS, 2011, p. 49); todavia, Portugal não está passando por nenhuma grande crise histórica, e nenhum conflito social é resolvido no romance. Quando lemos Camilo, a impressão que temos é de que nada muda - Portugal está “engessado", e o autor não parece acreditar numa transformação efetiva, de ordem coletiva. $\mathrm{Na}$ esfera individual, por sua vez, o homem comum é obrigado a se deslocar para outros países à procura da tão desejada mobilidade social.

O romance mostra que a fortuna, contudo, não é garantia de felicidade: Manuel Vieira acaba a história desgostoso e esmorecido. Rico, casa-se com a namorada de infância, 
não tem filhos e passa o resto de seus dias melancólico, lamentando as crueldades cometidas pela hipócrita sociedade oitocentista. Quando conhece a sua irmã, como ele, filha de uma mulher amante de um padre, percebe as dificuldades pelas quais muitos outros conterrâneos passam:

[a moça] parecia ainda temer-se do cárcere da Tamanca, narrando os desprezos que sua mãe sofrera, as injúrias que lhe atiravam ao coração despedaçado. Depois, falecida a mártir, e acabados os recursos da comiseração dos parentes, acorrentaram a órfã ao posto da indigência para ainda a insultarem como filha de tal mãe e sacrílega filha dum padre que havia sido a vergonha do clero.

Manuel Vieira [...] sofria, escutando-a; e já lhe pedia que se esforçasse por esquecer-se, a fim de não perder a fé na criação da espécie humana delineada na mente do Criador à semelhança de sua própria imagem. $(D O$, p. 467$)$.

Enriquecido, Manuel pode ter resolvido os problemas financeiros de sua família; entretanto, não resolveu os problemas de toda uma sociedade. Além disso, o dinheiro também não é visto como uma solução definitiva: na segunda parte do romance, os herdeiros de Vieira (irmãos, sobrinhos, parentes e amigos) engalfinham-se pela herança deixada por ele. Nas palavras proféticas de seu pai moribundo, que encerram a primeira parte da obra, “[...] o anjo do infortúnio faz muito menos vítimas que o demônio do ouro" ( $D O$, p. 468). Com isso, percebemos que Camilo nunca aponta uma saída - talvez por não acreditar verdadeiramente numa melhora no estado de coisas. O título de O Demônio do Ouro refere-se, assim, à "maldição" da riqueza, e o que as pessoas são capazes de fazer por dinheiro, abandonando todos os princípios éticos e morais. Além disso, o título também remete ao ciclo do ouro em Minas Gerais, período em que acontece a Inconfidência Mineira, pano de fundo que contribui no diálogo da narrativa camiliana com o subgênero histórico.

Assim sendo, segundo Ana Maria Marques, "longe do objetivo didático e de glorificação do passado nacional que é apanágio dos românticos Herculano ou Arnaldo Gama, o romance histórico de Camilo serve-se da História com uma finalidade estética e claramente 
comercial" (2010, p. 243); para ela, o autor transformaria "o passado numa fonte de boas histórias e num pretexto para algumas horas de "leitura amena"' (2010, p. 243). A nosso ver, no entanto, não se trata de somente levar o entretenimento para o público: ao mesmo tempo que oferece aquilo que o seu leitor queria consumir - um enredo de aventuras, repleto de referências a figuras históricas -, em O Demônio do Ouro Camilo vai além do esperado num romance histórico romântico e promove a crítica à sociedade oitocentista - principalmente a portuguesa -, em vez de optar pelo elogio ufanista. Contudo, apesar de sua tentativa de conscientização do público para as injustiças sociais, o autor não parece acreditar no poder transformador do povo - uma vez que a raiz dos problemas da nação se encontraria em seus próprios habitantes, com sua hipocrisia, ganância, desonestidade e tradição de dependência dos grandes proprietários -, o que distanciaria o seu romance do modelo scottiano.

Enfim, como procuramos mostrar ao longo deste subcapítulo, Camilo despreza o caráter educativo do romance histórico típico, questionando o tipo de conhecimento que ele leva ao leitor. O estudo da História, da maneira como é usualmente feito no século XIX pelos biógrafos, historiadores e romancistas, é por ele visto como acessório e inútil - assim como a descrição do pitoresco e da cor local - para a resolução dos problemas reais da sociedade. Como lembra Eduardo Lourenço, “inúmeras novelas de Camilo têm um enquadramento 'histórico', reportam-se ao passado mas não há nelas nenhuma paixão do passado como tal, nem da História com maiúscula [...]” (2006, p. 62, grifo do autor). Dessa forma, O Demônio do Ouro também propõe a crítica aos moldes romanescos importados - representados pela figura heroica e convencional de Filipe de Chesterfield e pelo ladrão rocambolesco Johnson Fowler -, que não corresponderiam à realidade portuguesa, mais próxima de um personagem prosaico como Manuel Vieira. 


\subsection{As Mulheres de Mantilha em que amor é este, entre pessoas que não se podem casar}

Em 1870, Joaquim Manuel de Macedo publicou As Mulheres de Mantilha: romance histórico, obra que, apesar de não constar entre as mais vendidas do autor, não fora completamente esquecida: "Galante de Sousa menciona 9 edições entre 1870 e 1974" (Cf. SERRA, 2004, p. 347). É uma das poucas obras de Macedo que trazem um recuo temporal, e seu subtítulo expõe claramente com o que o escritor pretendia dialogar: o romance histórico, subgênero a partir do qual a obra fora de fato recebida. Leandro Thomaz de Almeida cita uma nota sobre As Mulheres de Mantilha, "veiculada no Diário do Rio de Janeiro de 17/06/1871" (2008, p. 37), que "elogia a fidelidade histórica do romance ao retratar o Brasil colônia e diz que, nele, o leitor verá descritos 'os vexames do governo colonial, os costumes familiares e sociais dos fluminenses daqueles tempos e [isso] com tal minuciosidade e erudição que o leitor verá no seu trabalho antes uma crônica do que uma ficção’” (2008, p. 37). Segundo Almeida, essa nota apontaria "a utilidade do romance histórico na difusão da memória e conhecimento dos fatos nacionais" (2008, p. 37), e defenderia que "a ficção não deve sobrepor-se à verdade da história, nem a 'licença da imaginação' levar a certo anacronismo" (2008, p. 37). De acordo com o pesquisador, "Macedo parece ter cumprido bem esse propósito, ao menos na visão do autor desta nota, pois é comparado a Walter Scott e Fenimore Cooper, autores famosos de romances históricos sobre a Inglaterra e os Estados Unidos". (2008, p. 37).

O enredo do romance macediano se passa na década de 1760, em São Sebastião, Rio de Janeiro, durante o governo do vice-rei Conde António Álvares da Cunha - que realmente existiu, constando nos registros da História brasileira -, descrito na Introdução como um "homem talvez animado de boas intenções, porém tão facilmente irritável como 
violento e déspota" $\left(M M^{8}\right.$, p. 5). Marcada como um regime tirano, repleto de extorsões ao fisco, recrutamentos impostos como forma de abater opositores do governo e trabalhos forçados de escravos e homens livres pobres para obras do Estado, a administração do Conde da Cunha é ainda mais prejudicial ao Rio de Janeiro devido à presença nefasta de seu protegido, o ajudante oficial de sala Alexandre Cardoso de Meneses - que teria sido também um personagem histórico, "pois é citado por José de Souza Azevedo Pizarro e Araújo nas Memórias Históricas do Rio de Janeiro, editadas de 1820 a 1822” (Cf. CARDOSO, 2008, p. 23). Conforme o romance expõe, quem exercia de fato o poder na época era o ajudante oficial de sala, em quem o vice-rei confiava a ponto de permiti-lo tomar decisões sem necessidade de consulta prévia. Com isso,

Ao escrever As Mulheres de Mantilha, romance histórico, Joaquim Manuel de Macedo pretendeu construir um texto com base em fatos reais que mostrasse, para os leitores do século XIX, a vida do Rio de Janeiro nos idos de 1769, durante o reinado do Conde da Cunha. O subtítulo já anuncia este propósito que, ainda, é confirmado pela introdução do próprio autor, bastante informativa, criando no leitor a expectativa de um romance em que a ficção se subordine ao dado histórico. (FERRAZ; OLIVEIRA; GENS, 1988, p. 9).

Todavia, segundo Maria Cristina Ferraz, Ana Lucia de Oliveira e Rosa Maria Gens, "escrever uma crônica histórica, que se revelou, a princípio, como objetivo principal do livro, passa a ser elemento ornamental, conversa para 'matar o tempo', mostrando que as intenções do historiador seriam apenas um véu que encobre o romancista" (1988, p. 10). Nas palavras do narrador macediano, ao introduzir uma explicação histórica sobre a origem das brincadeiras de Carnaval, "enquanto não chegam os compradores de limões de cheiro que as meninas despacharam, matarei o tempo, conversando sobre o entrudo" (MM, p. 68, grifo nosso). Como afirmam Ferraz, Oliveira e Gens, "na verdade, os elementos objetivos da

\footnotetext{
${ }^{8}$ Ao longo deste trabalho adotaremos a sigla $M M$ sempre que citarmos o romance As Mulheres de Mantilha, de Joaquim Manuel de Macedo. As citações são retiradas da $3^{\text {a }}$ edição publicada pela Editora Melhoramentos (1965).
} 
crônica histórica percorrem a narrativa, surgindo aqui e ali, apenas armando um cenário que complemente as informações necessárias à compreensão da intriga" (1988, p. 10).

Como é possível perceber a partir da leitura do romance, no contexto histórico retratado o que mais chama a atenção do narrador não são necessariamente os desmandos políticos de um governo autoritário, mas o fato de Alexandre Cardoso ser um Don Juan inveterado, que se utiliza de seu poder para seduzir as mulheres, muitas vezes à força. De acordo com a declaração do narrador, que reproduz o discurso moralista da época, "pior ainda, era ponto incontroverso a impunidade do ajudante oficial de sala e dos protegidos do vice-rei que atentavam contra a honra das famílias, desrespeitando a inocência de donzelas, a honestidade de esposas, e o recato das viúvas" ( $M M$, p. 7). Ao longo da diegese, o narrador vai repetir esse tipo de discurso por diversas vezes, possivelmente a fim de agradar ao público que apreciava a defesa da moral e dos "bons costumes". No entanto, podemos encontrar alguns desvios na narrativa, que podem vir a levantar certos questionamentos sobre o suposto intuito moralista do autor.

Ainda na Introdução, o narrador sublinha a influência do bispo D. Fr. Antônio do Desterro, que, nas palavras dele, "prestou os mais importantes serviços à sua diocese, foi um bispo modelo na sua época e a severidade de que usou, de grande socorro à moralidade, ao ensino, à santidade do culto, e aos costumes do século [...]” $(M M$, p. 10). O seu elogio à austeridade do bispo, que agradaria ao leitor mais conservador, contrasta com a sua afirmação de que as mulheres o execravam por fomentar o Recolhimento do Parto e o Recolhimento de Itaipu, "onde muitas vezes abusiva e cruelmente alguns pais desterravam as filhas, alguns maridos encarceravam as esposas" ( $M M$, p. 9). Em outro momento, o romance descreve as "pobres freiras, que estavam nas grades a olhar para o mundo, de que se achavam perpétua e desumanamente banidas" (MM, p. 16). 
A crítica à submissão feminina, aliás, é realizada em diversas passagens da narrativa: numa delas, o narrador lamenta que "ainda naqueles tempos quase recentes, os portugueses e seus descendentes conservavam no sangue os germes de turvo ciúme mourisco que rouba a mulher à admiração e aos cultos dos homens e a condena à escravidão do zelo brutal" (MM, p. 162). Como ele explica, condenando tais tradições "recentes" - que, poderiam, portanto, ainda existir em algumas famílias - a mulher "era educada com preciso cuidado para não revoltar-se contra a inaudita prepotência; basta lembrar que era de regra que as filhas não aprendessem a ler e ainda menos a escrever" (MM, p. 31). De acordo com Sharyse Amaral, Macedo mostra "que o padrão da educação feminina do século XVIII era aquele onde o ensino das letras não era incluso, tendo como função manter a submissão da mulher" (2011, p. 128); por outro lado, "vale ressaltar que tanto a leitura quanto a escrita são descritas pelo autor como práticas que poderiam minar uma educação de clausura” (2011, p. 129).

Dessa forma, ao criticar a violência contra as mulheres, submissas à vontade despótica de pais e maridos - um despotismo apoiado pela Igreja -, o narrador macediano aponta os perigos do excesso de moralismo, e mostra a importância da alfabetização - e da literatura - como instrumento de conscientização. Ao reproduzir em sua obra vários lundus um tipo de "cantiga folgazona, sarcástica, erótica e muito popular" ( $M M$, p. 10), proibida pelo bispo referido anteriormente -, que serão lidos pela sua leitora oitocentista, Macedo contradiz os preceitos de pudor, relativizando a suposta moral do romance:

Já não se canta o lundu

Que o não quer o senhor bispo;

Mas eu já pedi licença

Da Bahia ao arcebispo.

E hei de cantar,

E hei de dançar,

Saracotear,

Com as moças brincar. 
E impunemente,

Cantando o lundu,

Ao bispo furente

Direi uh! uh! uh!

Fr. Antônio do Desterro

Quer desterrar a alegria;

Mas eu sou patusco velho,

E teimarei na folia. (MM, p. 10-11).

Assim, segundo Amaral, o autor "enaltece e até reconhece como nacional, tradições brasileiras de clara influência negra ${ }^{9}$. Um exemplo disso é o que Macedo diz acerca dos lundus no romance As Mulheres de Mantilha, defendendo-os de serem, necessariamente, imorais" (2001, p. 53): "Nem todos os lundus eram assim e pelo contrário alguns ostentavam a graça especial desse gênero de música sem de leve ofender o pudor de uma donzela, e tinham o grande merecimento de possuir certo caráter nacional [...]” (MM, p. 93). O romance sugere que a preconceituosa imagem do lundu - e de outras manifestações culturais - como uma cantiga imoral talvez fosse perpetrada pelo fato de ser utilizado como um instrumento de contestação: "Nos governos absolutos e opressores o desgosto público [...], antes de chegar a revolta, manifesta-se nas zombarias e nos insultos do pasquim, e nos versos e cantigas, de que não se conhece o autor, e se espalham e se decoram, e se repetem, a despeito da autoridade" (MM, p. 56). Como explica José Ramos Tinhorão, “[...] os lundus teriam constituído as primeiras canções de protesto, tendo como certo o papel político assumido por suas letras enquanto veículos de mensagens de crítica, e mesmo de oposição, ao poder colonial” (1992, p. 85).

Com o propósito de punir os seus opositores, que espalharam pasquins e entoaram lundus contra o governo, o vice-rei mandou proibir o entrudo, com a desculpa de ser um festejo imoral: nas palavras hipócritas de Alexandre Cardoso, trata-se de um "procedimento

\footnotetext{
${ }^{9}$ Discutiremos a questão do preconceito racial - e de como Macedo não se coaduna com esse tipo de discurso no capítulo 7.2.
} 
revoltado e de péssimo exemplo", "escandaloso jogo de entrudo" (Cf. $M M$, p. 77). Sendo assim, a defesa da moral é utilizada como justificativa para um regime tirano, "o carrancudo vice-reinado do conde da Cunha" ( $M M$, p. 13). A crítica do autor, todavia, não é somente dirigida à classe política, mas a toda uma sociedade moralista que condenava as mulheres "à escravidão do zelo brutal" (Cf. $M M$, p. 162), como analisamos anteriormente. Com isso, ao contrário do resgate de uma História "gloriosa" com o intuito de valorizar a nação, como usualmente encontrado nos romances históricos românticos, Macedo opta pela denúncia do autoritarismo e pela crítica social.

A fim de combater esse excesso de moralismo "carrancudo", Macedo dá espaço, em sua obra, para os festejos, as cantigas satíricas, o riso e - por que não? - a sensualidade. Dessa forma, verificamos que a longa descrição das festas populares também contrasta com o tom moralizante por vezes adotado pelo narrador. Se o intuito seria supostamente o de criticar esses costumes impudicos, causa estranhamento o fato de Macedo se ater a descrevê-los tão minuciosamente, como o faz com o entrudo, um jogo que "consistia essencialmente em molharem-se uns aos outros" (MM, p. 69):

Sem contestação havia muitos que abusavam da grande liberdade autorizada pelos costumes do entrudo; é positivo que nesse jogo desordenado, nessa reunião de tantos homens e senhoras que se apertavam em lutas, o pudor destas nem sempre escapava a atrevimentos que se perdoavam ou não. $O$ menor desses abusos ainda era um abuso pela intenção; o anelo ardente de um namorado, anelo que com frequência se realizava, sendo compreendido e tolerado à custa do rubor do pejo que assomava às faces da mulher amada, era quebrar com a mão um limão de cheiro suavíssimo sobre a parte superior e não velada do peito querido, de modo que a água odorífera lhe fosse banhar os cândidos seios. ( $M M$, p. 70).

Apesar de o narrador aparentemente reprovar os "abusos" dos namorados, não podemos negar que o parágrafo é descrito a partir de uma imagem sensual, o que acaba por 
contradizer o seu suposto intuito moralizante ${ }^{10}$. É também interessante notarmos que a personagem mais importante do romance não é um homem, e não tem os valores morais esperados em uma heroína. Trata-se de Maria de..., uma cortesã bela, inteligente e rica, de “independência audaciosa" e "natureza ardente e indomável” (Cf. $M M$, p. 25) ${ }^{11}$, que recebe os mais importantes figurões da sociedade brasileira da época, incluindo o ajudante oficial de sala, que é seu principal amante. São nos saraus e nas reuniões na casa de Maria que ocorrem os bastidores do governo: como está à margem das convenções sociais, a cortesã transita habilmente pela política, atividade reservada à esfera masculina, contribuindo na urdidura das teias do poder. As cenas protagonizadas por ela são as mais sensuais no romance, pois mostram uma mulher que manipula habilmente o desejo dos homens para conseguir o que quer:

Maria beijou a fronte de Gonçalo, e fugia-lhe; ele, porém, deteve-a, segurando-a pelo vestido e perguntou:

- Não basta de canto, de dança e de jogo, Maria?

A cortesã lançou sobre Gonçalo um olhar voluptuoso e delirante.

- Tens razão, respondeu ela; é tarde; as velas estão gastas, as luzes quase a apagar-se: que outras luzes, pois, se acendam.

E meia hora depois, estavam sós Gonçalo e Maria. (MM, p. 99).

Maria, vendo entrar o elegante oficial, correu para ele, exclamando:

- Tardavas-me!

Gonçalo Pereira recebeu-a nos braços e com fervor que aliás não encontrou resistência, beijou-a duas vezes nos lábios.

Sentaram-se ao lado um do outro com as mãos dadas, e com os olhos a gozarem-se [...].

- Conversemos... tornou Maria, procurando esquivar-se às carícias do amante amado.

- Sobra-nos o tempo, respondeu o oficial, insistindo.

A bela moça recuou, ameaçou Gonçalo com o leque, e fugiu a rir-se pela sala, enquanto ele a perseguia, rindo-se também.

\footnotetext{
${ }^{10}$ Uma análise mais aprofundada sobre a função do entrudo e das festas populares na narrativa macediana e sua relação com a sexualidade pode ser encontrada no prefácio "Entre véus, sombras e desejos", escrito por Maria Cristina Ferraz, Ana Lucia de Oliveira e Rosa Maria Gens, presente na edição de As Mulheres de Mantilha publicada em 1988 pela Secretaria Municipal de Cultura do Rio de Janeiro.

${ }^{11}$ Como afirma Eduardo Wright Cardoso, "hesito na definição a respeito de qual deles [Maria de... ou Alexandre Cardoso] assume proeminência no desenvolvimento do enredo, contudo, inclino-me a pensar que este posto é ocupado pela cortesã. Afinal, o romance trata justamente do plano vingativo deste personagem, suas armações, manipulações e desfecho.” (2008, p. 22-23).
} 
Como duas crianças, uma corria, outro cercava, correndo também: Maria ligeira e viva escapava rodeando o cravo e as cadeiras; mas por fim, deixando-se enganar ou enganada pelo falso ataque simulado por um lado, foi pelo outro cair nos braços de Gonçalo Pereira, soltando um fraco grito evidentemente de alegria menos pudica. (MM, p. 52).

Nos dois trechos, de claro teor sexual, Maria seduz Gonçalo Pereira em troca de informações, uma vez que ela lhe pede que espione os passos de Alexandre Cardoso, por suspeitar que este a estava traindo. De fato, o ajudante oficial de sala pretendia seduzir Inês que, juntamente com sua irmã, eram chamadas de "os dois lírios" -, filha de um abastado comerciante, com o propósito de raptá-la e forçar um casamento que seria lucrativo para ele. Através de uma complexa rede de informações - construída com dinheiro ou sedução -, Maria segue todos os passos de Alexandre, tecendo-lhe armadilhas:

Uma hora depois, todos os convidados tinham-se retirado; o último, Alexandre Cardoso, teimava em demorar-se.

- Tenho sono, disse-lhe Maria; quero ficar só e dormir.

- Maria!

- Feliz no jogo, infeliz no amor...

- Não jogarei mais...

- Não me importa que jogues ou não!...

- Mas o resto desta noite?...

- Disse a palavra: é um resto... e eu rejeito o resto...

- Maria!...

- Vá sonhar com o lírio. (MM, p. 31).

Novamente, nesta cena, temos também uma alusão sexual, pois ao leitor fica óbvio o motivo pelo qual Alexandre quer a companhia de Maria pelo resto da noite. Ela, por sua vez, propositadamente frustra o desejo do ajudante oficial de sala, a fim de saborear a sua vingança. Ao perceber que Alexandre não desiste de seduzir Inês, Maria começa a enviar cartas anônimas ao Conde da Cunha, denunciando os abusos de poder e os desmandos que o ajudante oficial de sala fazia à sua revelia. 
Com isso, o vice-rei incumbe Germiano, o seu criado particular, de espionar os passos de Alexandre, a fim de averiguar a veracidade das denúncias contidas nas cartas. $\mathrm{O}$ personagem é, por conseguinte, responsável por alguns episódios repletos de disfarces e mistérios folhetinescos (Cf. $M M$, p. 119, 146, 151-152, 188-190), bem ao gosto do público que apreciava esse tipo de narrativa. Sendo mudo - "escapara milagrosamente a uma febre perniciosa com derramamento cerebral; ficara porém mudo em consequência de paralisia da língua" (MM, p. 113) -, Germiano "representa um elemento quase indispensável nesse gênero literário, o grotesco; de gruta, próximo do belo-horrível, que foi um dos postulados românticos, principalmente o grotesco definido e louvado no célebre prefácio de Cromwell, de Victor Hugo" (PROENÇA, 1971, p. 25, grifo do autor). Não podemos nos esquecer de que, como apontamos anteriormente, "Nôtre-Dame-de-Paris surge como um padrão eterno" (Cf. BRUNO, 1886, p. 14) do romance histórico romântico, sendo o corcunda de Victor Hugo uma possível fonte de diálogo com o mudo Germiano.

Contudo, o criado particular do vice-rei tem uma participação muito pequena no enredo, parecendo ter sido colocado no romance como uma forma de atender às convenções do subgênero histórico e suscitar o interesse do leitor, afeito às narrativas de mistério. A partir da espionagem empreendida por ele, o Conde da Cunha confirma as acusações de Maria, acabando por prender Alexandre Cardoso e enviá-lo para Lisboa, “onde aliás acabou seus dias na maior e mais tormentosa miséria" (MM, p. 208). Entretanto, o "marquês de Pombal deixou também entender que o governo de Lisboa igualmente condenara a administração do conde da Cunha" (MM, p. 208), o qual acabou sendo "demitido de modo sem dúvida bem desagradável” ( $M M$, p. 208). Todavia, é importante lembrarmos que a queda do governo do conde da Cunha teve início com as cartas que Maria lhe enviou, que denunciavam os crimes do ajudante oficial de sala. 
Dessa forma, ainda que o narrador exalte as manifestações populares, tais como os pasquins e lundus, como formas de protesto, quem de fato teve o poder de mudar a situação política fora Maria. Ou seja, apesar de Macedo aparentemente colocar nas mãos do povo o poder de transformar a História - tal como o encontrado em Walter Scott (Cf. LUKÁCS, 2011, p. 72) -, a solução da crise histórica no romance é resultado da mera vingança prosaica de uma cortesã enciumada, não havendo nenhuma intenção heroica ou nacionalista por parte dela. Por outro lado, a obra carece da figura de um herói que represente os valores da nação, típico dos romances históricos românticos. Em seu lugar, temos uma mulher que afronta os valores morais da sociedade, não inspirando "sentimentos de bondade, de humanidade, e em geral a maior pureza de costumes", como apregoado pelo manual de Francisco Freire de Carvalho (1856, p. 296), cujos preceitos desejáveis para a construção de um exemplar do subgênero histórico foram discutidos por nós anteriormente.

Ainda que o narrador faça por vezes comentários moralistas à má reputação da cortesã, o fato é que o ajudante oficial de sala e o vice-rei são punidos no final do romance, enquanto ela encerra a história exatamente da mesma forma que começou, bela, rica e feliz: "Maria de... esqueceu depressa os gozos sinistros da sua vingança de vaidosa no empenho de novas conquistas e nos braços de novos amantes" (MM, p. 208). E ainda influente: "O vicereinado do velho conde de Azambuja durou apenas dois anos incompletos, sucedendo-lhe o marquês do Lavradio que [...] ardentemente se apaixonou por Maria de...” (MM, p. 208). Uma personagem, enfim, interessante e digna de continuar a ser matéria de romances, como afirma o narrador no parágrafo final da conclusão: "Mais tarde me empenharei em escrever a história ou o romance desses amores do vice-rei marquês do Lavradio e da formosa cortesã" $(M M, \mathrm{p}$. 208). Dessa forma, Maria é apresentada ao leitor de maneira mais positiva do que negativa, uma vez que fora graças a ela que o Brasil se livrara de um governo tirano. Sua condição de 
cortesã teria sido, assim, um "mal necessário" para que ela pudesse intervir no universo masculino dos bastidores do poder de maneira tão incisiva.

Em As Mulheres de Mantilha encontramos também outra figura intrigante: Isidora, que aparece na casa do pai de Inês pedindo asilo, pois estava sendo "vítima de infame perseguição" (Cf. $M M$, p. 65) por parte do governo. Assim, ela se adapta ao cotidiano da família e, dona de uma bela voz, acaba sendo requisitada para ensinar música aos "dois lírios”. Com isso, Inês acaba se apaixonando por Isidora - e é correspondida -, fato revelado nos diálogos entre as irmãs:

- Sinhazinha, perguntou Irene, qual é o moço com quem desejaria casar-te?

- Nenhum...

- Ora... estás mentindo...

- Não; já achei alguns bonitos, agora acho todos feios.

- Por quê?...

- Quase que tenho vergonha de dizer [...]. Quisera casar-me com um moço que tivesse o rosto, a voz, a bondade e a graça de Isidora [...]. Mas... que olhar o seu!...

- Muito suave... sem dúvida..

- Quando não é brilhante de fogo; porque, então, é abrasador.

- Ela nunca me olhou assim...

- [...] suponho que ela gosta muito de mim.

- [...] De que te serve gostar de uma moça como nós?...

- Eu sei! o que dizes é muito acertado; mas Isidora me encanta... não é por minha vontade, não entendo o que sinto; mas já duas vezes tenho visto em sonhos um moço com o rosto de Isidora.

- [...] Tens razão, Sinhazinha, Isidora te ama.

- E eu a ela muito, cada dia mais!

- Eu, porém, não entendo isto... que amor é este, entre pessoas que não se podem casar?...

- É verdade, Nhanhã; não me governo, porém, mais... amo Isidora... e nem compreendo a natureza do sentimento que a ela me cativa... (MM, p. 164166).

Mais adiante, encontramos a descrição de uma cena de paixão entre Isidora e Inês:

- Por que não quer cantar? Perguntou Inês a Isidora.

- Porque prefiro ouvi-la [...]. Depois que a vi e a ouço, já não sei cantar: preparo-me somente para chorar...

- Por quê? 
- Porque a amo...

- Mas eu também a amo, e muito!...

- Inês... Sinhazinha!...

- Somos duas moças e quase da mesma idade: que amor mais inocente e puro?... é o único, que não pode fazer chorar...

Isidora curvou a cabeça e roçou com os lábios a mão de Inês que estava sobre o parapeito da janela.

Inês estremeceu e corou sem saber por quê, recebendo aquele fugitivo beijo. (MM, p. 170-171).

O tom utilizado pelo narrador para descrever o amor entre as duas personagens é singelo, repleto de sentimentalismo romântico, não havendo em nenhum momento uma crítica à natureza supostamente "proibida", para a época, dessa paixão homoerótica, com exceção dos questionamentos feitos pelas duas irmãs, expressados num tom inocente. Inês é sempre descrita como uma moça pura e ingênua, filha de um homem honesto e honrado - "de bem merecida fama de probidade e de austeros costumes" (MM, p. 31) -, o que mostra uma grande distância entre esse registro macediano e as preconceituosas teses naturalistas da influência do meio e da hereditariedade que começavam a ser difundidas na época ${ }^{12}$.

No final do romance, porém, o narrador apresenta-nos uma reviravolta, numa cena de aventura típica do romance histórico de capa e espada dumasiano. No momento em que Inês sofre uma tentativa de rapto por parte de Alexandre Cardoso, Isidora levanta-se como uma "valente amazona" (Cf. MM, p. 173) em defesa de sua amada, "manejando a espada com braço varonil [...], ostentando o arrojo e a força de um leão" ( $M M$, p. 173), acabando por afugentar os ladrões. É aí que seu segredo é descoberto e revelado: Isidora "de fato era lindo jovem que se disfarçara com vestido de mulher para escapar ao recrutamento" ( $M M$, p. 175). Como explica Jocélio Teles dos Santos (1997), baseado na leitura do jornal O Alabama, de 1864, "era comum jovens se disfarçarem de mulher para livrar-se do recrutamento [...]. Foi essa a justificativa que Joaquim Manuel de Macedo no seu romance Mulheres de Mantilha

\footnotetext{
${ }^{12}$ Podemos encontrar esse olhar preconceituoso, por exemplo, nos romances naturalistas de Abel Botelho, $O$ Barão de Lavos (1891) e O Livro de Alda (1898), que tratam a homossexualidade como uma "tara".
} 
encontrou para explicar o travestismo da personagem Isidora(o)". É verdade que, ao longo da diegese, o narrador já havia dado algumas dicas para o leitor de que Isidora poderia ser um rapaz, ao descrevê-la como uma moça diferente das donzelas comuns:

Isidora era uma moça alta, esbelta, porém não bem feita de corpo; tinha o peito demasiadamente largo, e a cintura pouco delicada; [...] vestia-se com aquela exagerada e sinistra simplicidade que amesquinha as graças, e torna o corpo como um cabide do vestido.

Em uma palavra, Isidora era bela, mas desajeitada; brilhante bruto [...], precisava que a moda, lapidando-o, fizesse ostentar o seu elevado e natural valor. [...]

Foi este pelo menos o juízo que [...] fizeram sobre ela Irene e Inês.

[...] Só em um ponto não sabia acanhar-se; comia como Antônio Pires ou Jerônimo Lírio, que eram bons gastrônomos. (MM, p. 74-75).

Tal expediente, porém, parece-nos um tanto artificial, pois Isidora(o) consegue enganar não somente as inocentes irmãs, fazendo-as acreditarem que era uma moça, como também soldados experientes, o ajudante oficial de sala e o próprio vice-rei, que se encantou com os lundus que ela lhe cantara durante a recepção na casa do pai de Inês (Cf. $M M$, p. 107). Fica-nos a pergunta: seria possível um rapaz lograr todas essas autoridades somente por usar roupas femininas? Poderíamos depreender aqui uma falha de enredo, que não convence o leitor. Parece-nos, no entanto, que Macedo, nesse caso, teria lançado mão dessa deus ex machina a fim de não contrariar os códigos moralistas do século XIX, uma vez que a realização do amor entre duas moças poderia chocar os conservadores leitores oitocentistas. Apesar de ter apelado para uma saída convencional, transformando uma das personagens num homem - possibilitando o casamento entre elas -, é digno de nota o fato de essa paixão homoerótica ter sido sugerida durante grande parte do romance.

Dessa forma, apesar de em alguns momentos fazer uso de um discurso moralista, proclamando a defesa dos "bons costumes", o autor não parece se coadunar totalmente com esses ideais, uma vez que foca a narrativa em Maria, uma personagem que está longe de ser 
um exemplo de conduta - e que, principalmente, não é punida no final, nem muda o seu comportamento libertino. Além disso, as cenas com alusões sexuais e as descrições das cantigas e festas populares não seriam exatamente recomendáveis à educação das mocinhas no século XIX, leitoras do romance. Por fim, a paixão entre Inês e Isidora, personagem de sexualidade dúbia, jamais condenada pelo narrador, também nos serve de questionamento a esse suposto moralismo que seria defendido pela obra. Parece-nos, assim, que existiriam dois Macedos: um que reproduziria o discurso vigente, a fim de contentar o público mais pudico, e outro que se desviaria desses códigos morais, criticando-os.

Em contrapartida, as "mulheres de mantilha" do título referem-se às forças opositoras do governo: estudantes, como Isidoro, que "metamorfoseiam-se em mulheres de mantilha para escapar à fúria da gente oficial. Também Maria [...] utiliza a mantilha para montar um jogo de descobertas e armar ações [...]. Assim, figuras encobrem-se de véus e devassam a verdade, agilizando ações de rebelião" (FERRAZ; OLIVEIRA; GENS, 1988, p. 15). Todavia, como procuramos mostrar anteriormente, apesar de o narrador exaltar os protestos populares feitos através dos lundus e dos pasquins, quem de fato teve o poder de mudar a situação política fora Maria, uma personagem que muito se distancia da imagem do herói romântico, típica do subgênero histórico em voga na época. Ainda que a narrativa seja permeada de descrições pitorescas dos costumes e tradições nacionais, o romance não resgata a História do país com o intuito de valorizá-la, enaltecendo ações heroicas e gloriosas: antes encontramos um rebaixamento dessa tópica, uma vez que as ações da cortesã são pautadas pelo mais prosaico ciúme, e não pelo ideário nacionalista. Macedo se propõe a fazer em As Mulheres de Mantilha, portanto, um outro tipo de romance histórico, focado na crítica à condição submissa da mulher, motivada pelo moralismo exacerbado da sociedade brasileira, que, como nossa análise buscou demonstrar, é na obra posto em questão. 


\subsubsection{Casamento como única saída? Não em As Três Irmãs}

A condição submissa da mulher na sociedade não foi uma preocupação somente de Joaquim Manuel de Macedo: em Camilo Castelo Branco, esta também foi uma questão importante, o que nos obriga a abrir um parêntese em nosso trabalho. Como sabemos, o romance romântico, ao representar majoritariamente as camadas média e dominante da sociedade - ou seja, seus leitores -, acabou por marcar o lugar social da mulher por excelência: o de esposa e mãe, fadada à instituição do casamento. Um dos principais temas da ficção do Oitocentos, introduzido pelo romance inglês do século XVIII, é, sem dúvida, o casamento, visto como a grande problemática do universo feminino. Excluídas do mundo do trabalho, restava às mulheres a espera por um pretendente que pudesse substituir a figura do pai como provedor. Com isso, o ápice do projeto de vida feminino era casar-se com o homem escolhido por seu coração, um anseio onipresente nos romances da época. De acordo com Sandra Vasconcelos,

Na nova ordem burguesa [...], aos homens cabe trabalhar e sustentar a casa e às mulheres, a administração do mundo doméstico. [...] Não havia outro lugar para a mulher senão a casa do pai ou a do marido, pois era dificil para ela sustentar-se [...]. Sendo praticamente a única carreira aberta a elas, o casamento era um destino quase inescapável e as mulheres tinham de se preparar para ocupar o centro da família burguesa e assumir a criação dos filhos. (2007, p. 127-128).

Em As Três Irmãs - romance publicado primeiramente em folhetins e depois em volume no ano seguinte, em 1862 (Cf. CABRAL, Alexandre, 1988, p. 782), que acabou sendo esquecido pela crítica em meio a tantas obras publicadas pelo autor no mesmo período ${ }^{13}$,

\footnotetext{
${ }^{13}$ Entre 1861 e 1862 Camilo publicou outros sete romances e duas peças de teatro (Cf. FRANCHETTI, 2003, p. LX-LXII).
} 
dentre as quais destacam-se Amor de Perdição e Coração, Cabeça e Estômago -, Camilo nos apresenta uma personagem que muito se desvia dos modelos femininos da época. Jerônima, a irmã mais velha das três do título, é descrita logo no início como "a mais varonil no gênero de lavor a que se dava em casa, entendendo no tráfico, na labutação, e na contabilidade" $\left(T I^{14}, \mathrm{p}\right.$. 201); segundo o seu pai, ela era "o varão da casa" (Cf. TI, p. 201), e a mãe, "essa dizia muitas vezes a Jerônima: ‘Ó, moça! tu pareces-me um homem!’” (TI, p. 201). Mais adiante, ao contar sobre sua infância, o narrador afirma que ela "ria dos mimos que as irmãs andavam como a pedi-los ao pai; e, se este os queria repartir por as três, costumava ela dizer: - Eulália e Maria é que estão a morrer por festinhas; a mim dê-me antes um caderno de papel para eu fazer contas e traslados" (TI, p. 220). Além disso,

Os brinquedos de Jerônima eram de todo o ponto avessos aos ordinários na infância feminil. O que ela queria era um chapéu armado com plumas de papel, uma espada de cana, e, mais que tudo, um bote de cortiça com vela de chita, o qual ia marear no rio [...].

Dos doze anos em diante, Jerônima, hábil em escrita e contabilidade, ajudava o pai na escrituração, e lançava os borrões ao livro mestre [...]. ( $T I$, p. 221-222).

Bastam-nos esses exemplos para percebermos a distância que separa Jerônima das mulheres de seu tempo. Não somente a opinião do pai, que a via e a tratava como o "varão" da família, ou a opinião da mãe, que por diversas vezes criticava as suas atitudes masculinizadas, mostram o papel invertido dessa personagem na conjuntura social oitocentista. O seu gosto infantil, avesso às bonecas, e a sua habilidade para ajudar o pai negociante são indícios de sua recusa em aceitar a posição da mulher na sociedade, definida capítulos adiante com o bordão proferido pelo marido da irmã mais nova: "A mulher para a

\footnotetext{
${ }^{14}$ Ao longo deste trabalho adotaremos a sigla TI sempre que citarmos o romance As Três Irmãs, de Camilo Castelo Branco. As citações são retiradas do volume III das Obras Completas (1984).
} 
vida doméstica; o homem para a atividade" (TI, p. 228). O empenho da protagonista nas atividades típicas masculinas a leva a ser reprovada pela família:

Jerônima animou-o [o seu pai] a armazenar azeite, obrigando-se ela a tomar a si o encargo de dirigir a labutação. Riu muito o pai, e andou contando aos seus amigos a especulação em que estava afreimado o espírito da sua Jerônima. A Sra ${ }^{a}$. Mariana [sua mãe] cada vez descobria mais qualidades de homem na menina.

- A minha filha a governar armazéns de azeite! - exclamava ela. - Havia de ter graça, quando tua irmã [mais nova, que se casara com um fidalgo] descesse por Vila Nova com o seu vestido de veludo escarlate sobre um cavalo, saíres-lhe tu à porta do armazém a perguntar-lhe se queria comprar um odre de azeite! (TI, p. 224).

Perante tais críticas, Jerônima tenta voltar "o pensamento para outro lavor mais caseiro e adequado. Lembrou-se de fazer doce” (TI, p. 224). Tal atividade, típica do universo feminino, porém, ao contrário da contabilidade, deixa-a tão fadigada que seu pai a obriga a parar. Quando, mais tarde, ele adoece e morre, a personagem assume o papel de provedora da família, dirigindo os negócios, que acabam por seguidos golpes de azar indo à falência. Nesse ínterim, a família vive na pobreza, agravada pelo casamento infeliz da irmã mais nova, cujo marido fidalgo gastara todos os bens no jogo e morrera no Brasil. A outra irmã tivera mais sorte: acaba se casando com um advogado honesto, que, com os seus parcos rendimentos, compromete-se a sustentar a sogra e a cunhada viúvas.

No momento em que a família estava em grandes dificuldades financeiras - uma vez que a honestidade do advogado acabava por impedir que ganhasse o suficiente para a subsistência de todos -, Jerônima cogita casar-se com Pedro Monteiro, o homem que conta a história ao narrador camiliano. O pai dele, porém, opõe-se ao casamento, o que motiva a desistência de Jerônima, que acaba por escrever uma carta ao ex-futuro sogro, comunicando o seu rompimento com Pedro, defendendo a obediência filial. Segundo a irmã da protagonista, 
ela teria dito ao adoecer e saber do precário estado de saúde do seu ex-noivo, "que as mais felizes uniões se faziam no Céu..." (TI, p. 297).

Tal paixão súbita por Pedro não convence o leitor, e poderia ser apontada como uma falha do enredo. Podemos, no entanto, baseados nas atitudes de Jerônima, inferir algumas hipóteses. Em vez de amor, a protagonista pode ter se rendido ao desespero causado pelas dificuldades financeiras, acabando por ver no casamento com Pedro uma saída. Como o pai dele se opôs ao casamento, destituindo-o dos bens da família, não havia mais motivos para que ela aceitasse a união. Quanto à frase tipicamente romântica supostamente proferida por ela, não temos garantias de que tenha sido de fato dita por Jerônima: a sua irmã pode tê-la afirmado a Pedro para consolá-lo, ou, como o relato é feito ao narrador camiliano pelo próprio Pedro, é provável que este a tenha inventado, a fim de tornar a sua história a mais romanesca possível.

Com o fim do noivado com Pedro, Jerônima procura "cultivar prendas de costura, como marcar e bordar" (TI, p. 286), a fim de "habilitar-se para mestra de meninas" (TI, p. 286), indo procurar emprego como preceptora num vilarejo distante. Apesar de adotar um trabalho tipicamente feminino, a personagem não deixa de ser o varão da casa: quando o advogado acaba ficando na extrema miséria, Jerônima retorna com as economias que fez e salva a família.

Enquanto as mulheres da época repudiavam o trabalho, mesmo que doméstico - a típica donzela oitocentista é aquela que passa o dia a ler, bordar e tocar piano -, para Jerônima o trabalho é fonte de felicidade, como ela afirma: "Sabes quanto eu amo o trabalho. Só poderei ser feliz, considerando-me útil e recompensada de minha utilidade [...]. Se eu conseguir ganhar o meu modesto sustento com os meus esforços, hei de ter vaidade de mim mesma" (TI, p. 303). Apesar da insistência do cunhado para não ser mestra de meninas, a personagem se recusa a viver sob a sua tutela: "Que posso eu fazer na sua companhia? Contar 
os meus dias de indolência e inação. Sentar-me à mesa para tomar uma parte do produto da atividade alheia. Levantar-me da mesa para me empregar em trabalhos, quase inúteis, com que as mulheres costumam encobrir a sua ociosidade" (TI, p. 312). Após o duro juízo que faz das atividades femininas, ela acrescenta:

Depois, meu amigo, eu já sei que santo prazer é o da mulher que parece emancipar-se da sua fraqueza natural quando recebe o estipêndio da obra de suas mãos, e diz: - Ganhei com os meus esforços, com a minha capacidade, com a aplicação do meu espírito, este dinheiro que vale a minha subsistência de uma hora, de um dia ou de um ano! (TI, p. 312).

Assim, o trabalho é visto como uma forma de emancipação da mulher da dependência masculina, e dedicar-se a ele é uma maneira encontrada por Jerônima para se livrar do casamento. Ao ser indagada sobre qual seria a sua opinião acerca dos casamentos das irmãs, a personagem explica: "Gostava que elas fossem felizes solteiras; mas, se hão de ser mais felizes casadas, gosto que casem" (TI, p. 206). Neste trecho, não somente Jerônima assinala a sua diferença em relação às irmãs - que, como a grande maioria das mulheres do século XIX, viam o casamento como a única saída -, como defende a alternativa de ser solteira. Dessa forma, ela recusa a proposta de casamento do seu patrão ${ }^{15}$, um morgado rico e viúvo, mantendo-se fiel ao seu comportamento desde a adolescência:

Dos catorze aos quinze anos solicitaram-na em casamento [...] vantajosos partidos [...]. E todos ela rejeitara, sem soberba, sem os ter visto, nem comparado com outros. Consultava-se em relação à vida, e não ao homem. Faltava-lhe o conselheiro do coração. Sentia-o, sobrava-lhe sensibilidade para dedicação e excelências de filha; mas o instinto do amor, a inclinação à liberdade que erradamente as solteiras almejam na escravidão, mais ou

\footnotetext{
${ }^{15}$ Chama-nos a atenção a semelhança entre a história de Jerônima - preceptora das filhas de um homem rico e mais velho, que acaba se apaixonando por ela e lhe propondo casamento - e a de Jane Eyre, personagem-título do romance de Charlotte Brönte, publicado em 1847. Todavia, como não temos dados sobre a recepção dessa obra em Portugal, nem podemos afirmar com certeza se Camilo de fato teve contato com ela, registramos aqui apenas a curiosa aproximação entre as duas personagens. Ao contrário de Jane Eyre, no entanto, Jerônima recusa o casamento com o patrão, afastando-se, assim, das atitudes esperadas de uma personagem feminina no século XIX.
} 
menos leve, das cadeias matrimoniais, aquele natural que a ciência fisiológica vos afirma que existe inseparável do coração da mulher, não o tinha Jerônima. (TI, p. 222-223, grifo nosso).

Nesta passagem, a voz do narrador expressa a opinião de Jerônima, que relaciona o casamento a uma escravidão, a uma prisão. Por outro lado, o narrador aponta em diversos momentos que a personagem não é um ser insensível, pois ama os seus pais e suas irmãs a ponto de sacrificar a sua saúde para sustentá-los - e deixa bem claro: o que falta a ela é a paixão sentida pelo sexo oposto. Com isso, Camilo nos mostra em As Três Irmãs uma personagem que muito diverge das convenções sociais do século XIX, comumente difundidas pelos romances românticos: uma mulher que desafia os papéis sociais preestabelecidos no modelo patriarcal e não vê o casamento como a única saída.

Um ponto que aproxima a personagem Jerônima, de Camilo, das personagens Maria de..., Isidora e Inês, de Macedo, é o fato de ambos os narradores as tratarem de modo sério, e não cômico, não sendo caricaturas destinadas ao riso do leitor. Jerônima - ao contrário de tantos personagens da galeria camiliana - não é ridicularizada pelo narrador, e suas atitudes masculinizadas são antes louvadas do que criticadas, pois garantem a sobrevivência de sua família. Já Maria de... é vista como uma sedutora e inteligente mulher, cuja condição social de cortesã a permitiu manejar e intervir na esfera masculina do poder político, mudando os rumos da nação. A paixão entre Inês e Isidora, por sua vez, é descrita com a mesma beleza e sensibilidade encontradas nos romances românticos mais convencionais, que tratam do amor heterossexual. Assim sendo, verificamos que Camilo e Macedo quebraram certos paradigmas da ficção oitocentista, apresentando nessas obras mulheres fora dos padrões de comportamento impostos pela sociedade portuguesa e brasileira do século XIX. 


\section{Do científico para o social: o discurso naturalista refutado}

Apesar de a crítica mais sedimentada, em Portugal e no Brasil, comumente repartir o século XIX em dois períodos distintos, o "romântico" e o "realista/naturalista", é fato que os limites entre eles são difusos, uma vez que, como sabemos, a divisão rígida da história literária é artificial e não se sustenta a uma análise mais detida. Segundo essa divisão, a escola realista/naturalista teria supostamente substituído a romântica a partir da Questão Coimbrã, em 1865, e das Conferências do Casino, em 1871. Os ideais da chamada Geração de 70 teriam atravessado o Atlântico e acabado por influenciar os escritores brasileiros, sobretudo a partir da década de 1880.

Todavia, observamos que, além de continuar lançando no mercado português novos romances durante os anos 1870 - tais como A Mulher Fatal (1870), O Regicida (1874), A Filha do Regicida (1875) e A Caveira da Mártir (1876) -, Camilo Castelo Branco publica entre 1876 e 1899 da quarta até a décima edição de Amor de Perdição (Cf. MARQUES, H., 1925, p. 190-191), mostrando que o público continuara apreciando os romances da "velha geração” até o final do século XIX. Como verificamos no catálogo da Livraria Internacional de Ernesto Chardron, Bibliografia Portuguesa e Estrangeira, de 1881, As Memórias d'um Médico (1846-1853), de Alexandre Dumas, encontram-se em destaque, e Os Dramas de Paris (1857-1870) protagonizados pelo Rocambole de Ponson du Terrail ainda eram um sucesso na

década de 1880: segundo o editor avisa, "restam poucos exemplares". É pertinente relembrarmos aqui do anúncio, discutido por nós anteriormente, encontrado na portuense Gazeta Ilustrada: o Ateneu Artístico-Literário, também de 1881, que faz propaganda das narrativas de viagem de moldes românticos. 
No Brasil, por sua vez, Joaquim Manuel de Macedo publica da quinta à décima edição de A Moreninha entre 1872 e 1899 (Cf. SERRA, 2004, p. 326-327), tendo várias de suas obras presentes no catálogo de 1870 da Biblioteca Nacional, de acordo com a pesquisa de Valéria Augusti (1998) anteriormente referida, mostrando que permanecera no gosto dos leitores. Além disso, como apontamos no capítulo anterior, o prefácio a Os Franceses no Rio de Janeiro (1870), de Manoel Duarte Moreira de Azevedo, reproduz, ainda na década de 1870, os lugares-comuns do romance histórico romântico. Nesse período também foram publicadas importantes obras do romantismo brasileiro, tais como A Pata da Gazela (1870), O Tronco do Ipê (1871), Ubirajara (1874) e Senhora (1875), de José de Alencar, e $O$ Seminarista (1872) e A Escrava Isaura (1875), de Bernardo Guimarães.

Se os romances românticos continuavam a ser consumidos durante a década de 1870 e 1880, também podemos afirmar que os ideais realistas/naturalistas não surgiram, repentinamente, nas Conferências do Casino. Pelo contrário, começaram a se formar desde pelo menos a década de 1840, com a difusão de obras filosófico-científicas no meio intelectual português e brasileiro. Segundo Maria Helena Santana,

Apresentando-se como o cânone de toda a ciência positiva, o Cours de Philosophie Positive [de Auguste Comte] (publicado entre 1830 e 1842) terá uma influência decisiva na cultura europeia, a partir de meados do século. Sob a forma de um novo enciclopedismo, esta obra fornece um sistema filosófico racionalista e antimetafísico, ao mesmo tempo que estabelece uma teoria do conhecimento baseada nos métodos das ciências naturais. (2007, p. 39).

A partir das ideias de Auguste Comte, foi desenvolvido todo um discurso positivista embasado em teorias de cunho científico. Como a pesquisadora explica, "grande parte do discurso social positivista apoia-se nas teorias desenvolvidas a partir dos anos 40-50 sobre a hereditariedade mórbida e a degenerescência" (2007, p. 63), defendidas em trabalhos como o Traité Philosophique et Physiologique de l'Hérédité Naturelle, de Lucas (1847), as 
Considérations sur les Causes de la Dégénération Physique et Morale du Peuple dans les Grandes Villes, de Bertulus (1847), e o Traité des Dégénérescences Physiques, Intellectuelles et Morales de l'Espèce Humaine, de Morel (1857) (Cf. SANTANA, 2007, p. 63). De acordo com Jacinto do Prado Coelho,

Entre 1840 e 1850, multiplicam-se em França as "fisiologias", monografias literárias que procedem de "duas ideias sistemáticas: as espécies sociais são, como as espécies animais, o produto do meio em que se desenvolvem; as paixões humanas são, como as doenças, casos orgânicos" [Maynial, L'Époque Réaliste]. Esta tendência provoca um reflexo jocoso em Garrett [em Viagens na Minha Terra, de 1846], que, ao definir o tipo barão, recorre ao latim dos naturalistas e cita Lineu e Buffon. Na verdade, estava na moda aludir a Buffon e a Cuvier ao fazer classificações psicológicas. (2001, p. 102 , grifo do autor).

Sílvio Romero, em O Naturalismo em Literatura, publicado em 1882, ao analisar a História de Porto-Real (1840-1859), de Sainte-Beuve, afirma que a obra "não apareceu por milagre; ele [o autor] estava em harmonia com o momento histórico em que se desenvolveu [...]. Os seis principais elementos da crítica eram já uma realidade na época de seu aparecimento e ainda mais se desenvolveram depois dele" (1882, p. 16). Segundo Romero, estes elementos seriam:

a mesologia em que Gervinus, Buckle e Curtius foram mais exímios do que o crítico francês; a etnologia em que Herder, Thierry e Renan o excederam; a fisiologia em que Taine e o próprio Zola levam-lhe vantagem; a psicologia, [...] onde Hermann Hettner e Karl-Frenzel o igualam; as correntes e influências históricas que Macaulay e Villemain foram sempre hábeis em indicar, e, finalmente, o julgamento científico, último e definitivo, que ninguém formula melhor do que Edmond Scherer e Julian Schmidt. Com estes dados estudam-se os povos e os indivíduos, determinando nos primeiros a natureza de suas instituições e nos segundos a índole de suas criações. (1882, p. 16-17, grifo do autor).

Um exemplo de que o discurso cientificista já estava presente no meio intelectual brasileiro desde a década de 1840 é a passagem de A Moreninha (1844), em que Macedo 
parodia o discurso propalado pelas três principais correntes científicas da medicina, ao mostrar os seus personagens, futuros médicos, divertindo-se com a embriaguez da ama de leite da protagonista, não percebida pelos convivas do baile, que acreditavam tratar-se de uma doença:

- Diremos tudo o que vier à cabeça, ficando entendido que as honras pertencerão ao que maior número de asneiras produzir [...].

- [...] Eu diagnostico uma baquites. Concebe-se perfeitamente que as etesias desenvolvidas pela decomposição dos éteres espasmódicos e engendrados no alambique intestinal, uma vez que a compressão do diafragma lhes causa vibrações simpáticas que os façam caminhar pelo canal colédoco até o perióstio dos pulmões [...]. Daí, passando à garganta, perturbam a quimificação da hematose, que por isso se tornando em linfa hemostática, vá de um jato causar um tricocéfalo no esfenoide, podendo mesmo produzir uma proctorragia nas glândulas de Meyer, até que, penetrando pelas câmaras ópticas, no esfíncter do cerebelo, causa um retrocesso prostático, como pensam os modernos autores, e promovem uma rebelião entre os indivíduos cerebrais: por consequência isto é nervoso. $\mathrm{O}$ tratamento que proponho é concludente: algumas gotas de éter sulfúrico [...]; e quando isto não baste, o que julgo impossível, as nossas lancetas estão bem afiadas e duas libras de sangue de menos não farão falta à doente: disse.

- Como ele fala bem, murmurou uma das moças.

Fabrício tomou a palavra.

- Sangue! sempre sangue! eis a medicina romântica do insignificante Broussais! mas eu detesto tanto a medicina sanguinária, como a estercorária, herbária, sudorária e todas as que acabam em ária [...]. Uma mulher padecia este mesmo mal [...]; quis o seu bom gênio que ela recorresse a um homeopata, que, com três doses, das quais cada uma continha apenas a trimilionésima parte de um quarto de grão de nihilitas nihilitatis, a pôs completamente restabelecida [...].

- Senhores, eu devo confessar que restam-me muitas dúvidas a respeito do diagnóstico e, portanto, julgo útil recorrermos ao magnetismo animal, para vermos se a enferma, levada ao sonambulismo, nos aclara sua enfermidade. Além disto, eu tenho fé de que não há moléstia alguma que possa resistir à maravilhosa aplicação dos passes, que tanto abismaram Paracelso e Kisker. ( $M$, p. 81-83, grifo do autor).

Assim, utilizando-se de palavras vazias e sem sentido, nas afirmações repletas de jargões médicos inventados, “produzindo asneiras”, Macedo ridiculariza o discurso científico da época, mostrando que este já era difundido no Brasil em meados da década de 1840. Camilo, por sua vez, em $O$ Que Fazem Mulheres (1858), aponta a presença do cientificismo nos anos 1850 em Portugal, ridicularizado na fala de um dos personagens: 
Porque os vossos charutos, propinadores de venenos, enegrecem as substâncias orgânicas, como o ácido sulfúrico.

São amargos e cáusticos como o ácido nítrico.

Calcinam os beiços como o ácido hidroclórico.

Queimam a laringe como o ácido fosfórico.

Laceram o esôfago como o acetato de chumbo.

Fulminam e despedaçam como o ácido hidrociânico. (QFM, p. 1238).

Esta sucessão de termos químicos, colocados de maneira gratuita, parodiam o linguajar científico ao mesmo tempo que são criticados ironicamente pelo narrador camiliano, que afirma que “um 'manual de química para uso dos leitores de romances' é instantemente reclamado. Sente-se na literatura este vazio, desde que a novela é um estendal da ciência humana" ( $Q F M$, p. 1239). Outro personagem é chamado pelo narrador de "o autor possível do SÉCULO PERANTE A CIÊNCIA" (QFM, p. 1252, grifo do autor), livro que ele pretende escrever mas nunca conclui: "Convicto da excrescência espiritual, crê-se dotado de fluidos nérveos, magnetismo, eletricidade, eterização. Julga-se enfim anestésico, espasmódico, dinâmico, enfim tudo o mais que não se entende" ( $Q F M$, p. 1247). Ridicularizando seu personagem, Camilo também zomba do discurso cientificista já em voga na década de 1850.

De acordo com Maria Helena Santana, "tendo já estabelecidas as suas bases doutrinárias, o positivismo terá que ajustar-se, em meados do século, à revolução provocada pelas teorias evolucionistas" (2007, p. 46), propaladas pela publicação, em 1859, de On the Origin of Species by Means of Natural Selection, de Charles Darwin. Segundo a pesquisadora, “a lição darwiniana daria lugar a apropriações filosófico-ideológicas - o chamado 'darwinismo social' - com larga repercussão na época. Todos os discursos científicos ou pseudocientíficos sobre o homem e a sociedade gravitam desde então em torno do darwinismo" (2007, p. 50). Seis anos depois, em 1865, é publicada a Introduction à l'Étude de la Médecine Expérimentale, de Claude Bernard, obra que serviu de base para Émile Zola desenvolver a sua teoria do "romance experimental", aplicada em Thérèse Raquin (1867) e postulada em 1880: 
Claude Bernard demonstra que este método [experimental] aplicado ao estudo dos corpos brutos, na Química ou na Física, deve ser igualmente aplicado ao estudo dos corpos vivos, em Fisiologia e Medicina. Vou tentar provar por minha vez que, se o método experimental conduz ao conhecimento da vida física, ele deve conduzir também ao conhecimento da vida passional e intelectual. (ZOLA, 1979, p. 26).

Sem me arriscar a formular leis, julgo que a questão da hereditariedade tem uma grande influência nas manifestações intelectuais e passionais do homem. Também dou uma importância considerável ao meio. (ZOLA, 1979, p. 42).

Dessa forma, como explica Santana, "o naturalismo literário emerge precisamente na fase mais triunfante da medicina francesa, ou seja, a da consagração institucional e cultural do paradigma fisiologista. Mas deve-se notar que o interesse suscitado pelos temas médicos é anterior" (2007, p. 59). De acordo com Afrânio Coutinho, "esse foi o ideário filosófico a que se deveu o cânon crítico da era materialista. No Brasil, a geração que se iniciava na vida intelectual a partir de 1870 foi toda ela, nos diferentes centros intelectuais do país, impregnada desse espírito de época” (2002, p. 23), um “espírito de época” que, como vimos, foi se desenvolvendo no mundo lusófono ao longo do século XIX, desde as décadas de 1840 e 1850. Segundo Nélson Werneck Sodré, “o naturalismo brasileiro apresenta, no reduzido acervo que chegou a constituir, muito mais obediência ao cientificismo do que a outra coisa" (1992, p. 90); em Portugal, a nosso ver, o cientificismo também foi marca da produção literária naturalista, representada pela obra de Abel Botelho.

Sendo assim, foi nosso intuito aqui mostrar que o naturalismo não se originou subitamente nas Conferências do Casino, mas foi gestado durante décadas antes, com a difusão de teorias científicas que acabaram sendo transportadas para a literatura. Se Macedo e Camilo, como apontamos páginas atrás, já criticavam o discurso cientificista nos anos 1840 e 1850, é verdade que não poderiam deixar de fazer isso às portas da década de 1870, quando esse discurso se intensificara, ou na década de 1880, quando o naturalismo já se tornara moda literária. É o que procuraremos investigar a seguir. 


\subsection{O Senhor Ministro e o elemento mesológico de objetivo imanente ou transcendente}

Em 1879, Camilo Castelo Branco publicou Eusébio Macário, romance que, juntamente com a sua continuação $A$ Corja, lançada no ano seguinte, deu ensejo a uma de suas mais célebres polêmicas, a com Alexandre da Conceição, escritor naturalista português. Embora alguns tenham reputado essas obras a uma suposta rendição de Camilo à nova estética, outros, como Conceição, compreenderam o claro intuito paródico do autor, incomodando-se com ele.

Apesar de colocar como subtítulo de Eusébio Macário - "História natural e social de uma família nos tempos dos Cabrais" - uma evidente "imitação, um 'pastiche' do que acompanha a série Les Rougon-Macquart de Zola, 'Histoire Naturelle et Sociale d'une Famille sous le Second Empire"” (LIMA, 1992, p. 121), Camilo pede, numa "Nota preambular”, “o favor de não decidir já que o autor plagiou Emílio Zola. Eusébio Macário não é Rougon Macquart; nem Uma família no tempo dos Cabrais é Une famille sous le seconde empire. Sim, eles, os Cabrais, não são perfeitamente o Segundo Império" $\left(E M^{1}\right.$, p. 455, grifo do autor). Neste irônico trecho, o autor sugere não ter a intenção de imitar a literatura francesa de cunho naturalista, uma vez que o contexto social e político português não são os mesmos do da França - apesar de compartilharem a tirania, o Cabralismo português obviamente não fora tão grandioso quanto o regime de Napoleão III. Da mesma forma, para Camilo, a literatura produzida na (semi)periferia não poderia ser uma cópia exata da produzida no principal centro cultural europeu da época. No prefácio à segunda edição de Eusébio Macário, o escritor afirma que

\footnotetext{
${ }^{1}$ Ao longo deste trabalho adotaremos a sigla EM sempre que citarmos o romance Eusébio Macário, de Camilo Castelo Branco. As citações são retiradas do volume VIII das Obras Completas (1988).
} 
Eu não conhecia Zola e ainda agora apenas e escassamente o conheço de o ouvir apreciar a uma pessoa de minha família que me fez compreender a Escola com duas palavras: "É a tua velha Escola com uma adjetivação de casta estrangeira, e uma profusão de ciência compreendida na 'Introdução aos Três Reinos'. Além disso, tens de pôr a fisiologia onde os românticos punham a sentimentalidade: derivar a moral das bossas, e subordinar à fatalidade o que, pelos velhos processos, se imputava à educação e à responsabilidade". (EM, p. 463-464).

A partir deste prefácio, verificamos que Camilo não pretende dialogar diretamente com Émile Zola - cuja obra ele "escassamente conhece" -, mas com a imagem difundida em Portugal, de certa forma estereotipada, da literatura naturalista, plasmada nos lugares-comuns da "adjetivação de casta estrangeira", na "profusão de ciência", na "físiologia" e na "fatalidade" do meio e da hereditariedade. Ao afirmar na "Advertência" que os processos utilizados no romance seriam “o estudo dos meios, a orientação das ideias pela fatalidade geográfica, as incoercíveis leis fisiológicas e climatéricas do temperamento e da temperatura, o despotismo do sangue, a tirania dos nervos, a questão das raças, a etologia, a hereditariedade inconsciente dos aleijões de família, tudo, o diabo!" (EM, p. 465), o autor escancara a sua intenção paródica. De acordo com Isabel Pires de Lima, “terminar esta enumeração com um 'tudo' globalizante e com a exclamação 'o diabo!' retira qualquer seriedade ao idioleto cientificizante utilizado" (1992, p. 125).

$\mathrm{Na}$ mesma "Advertência", Camilo explica ironicamente que "trabalha desde ontem" (EM, p. 465) na "História natural e social de uma família no tempo dos Cabrais", que “dá fôlego para dezessete volumes compactos, bons, duma profunda compreensão da sociedade decadente" (EM, p. 465), dos quais "já tem prontos dez volumes para a publicidade" (EM, p. 465). À parte de sua clara intenção zombeteira, que ridiculariza o extenso projeto de Zola, temos que o "projeto" iniciado em Eusébio Macário foi seguido da publicação de $A$ Corja, no ano seguinte, e teve uma espécie de continuação em $O$ Senhor Ministro, um romance curto publicado em 1882, quase nunca lembrado pela historiografia 
literária e raramente estudado pelos camilianistas ${ }^{2}$. De fato, $O$ Senhor Ministro já havia sido parcialmente publicado em 1878 na revista O Ocidente, com o título Onde Está o Ministro? Romance realista de costumes constitucionais, mas foi alterado e aumentado depois, tendo sido novamente publicado em 1882 no primeiro volume da miscelânea intitulada Narcóticos (Cf. CABRAL, Alexandre, 1988, p. 540), provavelmente com o intuito de integrar a "História natural e social de uma família no tempo dos Cabrais". Como procuraremos mostrar a seguir, O Senhor Ministro retoma algumas personagens e procedimentos estéticos das duas primeiras obras, trazendo-lhes uma conclusão através de uma possível chave interpretativa.

$\mathrm{Na}$ “Advertência" do romance, Camilo apresenta uma estratégia semelhante à que utilizara na "Nota preambular" de Eusébio Macário. O autor afirma que imitara o título da obra do escritor português naturalista Teixeira de Queirós: "No catálogo das Obras em preparação do primoroso romancista Sr. Teixeira de Queirós, está inscrito, como elementar na COMÉDIA BURGUESA, um volume intitulado: O Senhor Ministro. Claro é que lhe plagiei o título" ( $S M^{3}$, p. 619, grifo do autor). Com isso, Camilo sugere que irá dialogar com a escola naturalista, mostrando, entretanto, que se distancia dela: "Posso, porém, afoitamente gabar-me de que o Sr. Teixeira de Queirós não meditou escrever nem jamais escreverá um ministro da espécie do meu” (SM, p. 619). Dessa forma, o autor avisa ao leitor que não deve esperar deparar-se, em seu $O$ Senhor Ministro, com os mesmos lugares-comuns do naturalismo encontrados, por exemplo, em Teixeira de Queirós.

\footnotetext{
${ }^{2}$ Escolhemos trabalhar aqui com $O$ Senhor Ministro, em vez de Eusébio Macário ou A Corja, justamente por esse motivo. Os dois últimos romances já foram suficientemente estudados por críticos renomados como Isabel Pires de Lima, Maria Saraiva de Jesus e José Cândido Martins, enquanto O Senhor Ministro permanece praticamente desconhecido. Os únicos estudos que conseguimos encontrar sobre essa obra foram os prefácios de João Bigotte Chorão ([1989]) e Isabel Segorbe (2000), que trazem aspectos curiosos mas não constituem análises propriamente ditas, além da conferência apresentada por Isabel Pires de Lima na abertura do Congresso Internacional Camilo Castelo Branco e o Oitocentos: 150 anos do Amor de Perdição, realizado na Universidade de São Paulo em 2012, em texto ainda inédito, ao qual não tivemos acesso.

${ }^{3}$ Ao longo deste trabalho utilizaremos a sigla $S M$ sempre que citarmos a obra $O$ Senhor Ministro, de Camilo Castelo Branco. As citações são retiradas do volume XV das Obras Completas (1993).
} 
O romance trata da vida de Tibúrcio, amigo de farras de Fístula - personagem de Eusébio Macário e A Corja -, e a sua suposta regeneração pelo amor de Amália, sobrinha do padre João. Enquanto mostra o desenvolvimento da relação entre os enamorados - uma relação que, graças à esperteza de Amália e ao seu cálculo para arranjar um casamento vantajoso, não passava de cartas trocadas e namoros à janela -, o narrador insere momentos da vida passada (e desregrada) de Tibúrcio, cujos pais desejavam que se ordenasse e, por isso, mandavam-lhe dinheiro para sustentar os seus estudos sacerdotais em Braga. Após o rapaz ter gasto grandes somas em seus pretensos estudos - na verdade, na vida vadia que levava com Fístula -, decide enganar os pais e abandona a carreira eclesiástica. Quando os boatos de suas farras chegam aos ouvidos dos familiares, estes resolvem mandar o filho mais velho a Braga: com isso, "além do que era exato, o irmão do estudante, que via com inveja [...] as despesas de Tibúrcio [...], regressou com informações piores do que obtivera. Como lhe contassem que o Tibúrcio estivera num baile de Entrudo [...] vestido de vivandeira, o irmão foi contar que o Tibúrcio andava por Braga, de noite, vestido de rameira” (SM, p. 651).

Irados, os pais decidem cortar a sua mesada. Como o narrador relata, ironicamente, "esse desastre coincidiu com a resolução heroica de Amália" (SM, p. 651), de terminar o namoro no qual não vislumbrava futuro. Assim, instado por Fístula a ver se o padre “dá dote à sobrinha e [o] casa [...] com ela" (SM, p. 652), Tibúrcio passa a enxergar um novo horizonte para esse relacionamento e procura se regenerar perante Amália, aplicando-se nos estudos de Direito e conquistando a estima do padre João, que aprova o casamento dos dois e deixa um polpudo dote à sobrinha. Ao fim da narrativa, o protagonista procura ascender na carreira política, sendo-lhe atribuído o título de ministro, porém, não do Estado, mas da Ordem Terceira de S. Francisco.

Caracterizada ironicamente pelo narrador como uma "empada etnológica” (SM, p. 642), ridicularizando o termo usualmente empregado pelos naturalistas, a obra dialoga com o 
discurso cientificista em diversos momentos, como na passagem em que descreve o início da paixão entre Tibúrcio e Francisca, a menina que o rapaz cortejava antes de conhecer Amália:

\begin{abstract}
Jogavam as pedrinhas e outros jogos em que o que perdia levava às costas o que ganhava. Era ela quase sempre a que perdia. Os contatos, as curvas sensitivas, os relevos quentes, inflamatórios, eram-lhes já conhecidos, quando se aproximaram em uma idade que a memória destas pueris brincadeiras avermelha o pudor nas faces. Mas o pudor das aldeias do Minho e as castanhas principiavam a desaparecer por esse tempo.

Está explicado o meio. São duas vítimas inconscientes da mesologia, ciência moderna que tem do grego a etimologia suficiente para desculpar as patifarias antigas. (SM, p. 637).
\end{abstract}

A "mesologia" e a pretensão naturalista de explicar os comportamentos humanos através da ciência são, por sua vez, retomadas em outro trecho, com uma ironia ainda maior devido ao seu esvaziamento de significado: "Este episódio parece baixo em história tão levantada; mas quem sabe os processos perscruta logo que este pormenor é um elemento mesológico, e que daí deve explosir algum objetivo imanente ou transcendente" (SM, p. 644). Além disso, o narrador também critica os preconceitos difundidos pelo naturalismo, ao defender que todas as irmãs de Amália "casaram vantajosamente com bacharéis e doutores" (SM, p. 648): “do seio da pobreza [...] saíram pela porta da honra aquelas formosas raparigas que pareciam predestinadas para baixos e talvez vergonhosos destinos. Aparecem, às vezes, estas exceções que desmembram a mal articulada escola pessimista que do âmago de um meio de pobreza tira sempre fatalmente a desonra" (SM, p. 648).

Analisando os procedimentos estéticos parodiados da escola naturalista, destacamos o tom baixo e grotesco de algumas passagens e descrições, de "um naturalismo que só hoje se permite nos romances" (SM, p. 679), nas palavras do narrador camiliano. A atenção, por exemplo, que o narrador dá aos processos digestivos do padre - desnecessários ao desenvolvimento da diegese -, utilizando-se do vocabulário fisiologista, está a serviço da paródia: 
Arrotava cidrão que comera extraordinariamente [...]. Vinha por isso receando quebra no aço do seu estômago; e, pondo a mão no bucho timpanítico, consultava se devia naquela noite abster-se do seu caldo de galinha e vaca para não sobrecarregar a tripa. Ele entendia que um homem, desde os gorgomilos por aí abaixo até onde a fisiologia o faz e desfaz, era tudo tripa singular e a todos os respeitos única. (SM, p. 623).

O padre João, por sua vez, é descrito como um corrupto que fez fortuna enganando os fiéis, abrindo "as portas do Céu com pé de cabra, metendo na bem-aventurança gente impossível” (SM, p. 626) - "usurárias, intriguistas, feias e concubinárias sacrílegas de frades" (SM, p. 626) -, que comprava o perdão divino "deixando ao seu confessor 30000 cruzados em peças e dobrões" (SM, p. 626). Segundo o narrador, o padre deixara a sua fortuna para as sobrinhas porque não tinha filhos: "A este respeito, dizia ele, sem distinção de sexos, que era uma vestal. [...] Padre Matias espirrava uns froixos de riso sarcástico e gosmava: 'A respeito de vestal, tó-carocha! que mo venha dizer a mim esse hipócrita [...]. Falem-lhe na Tamanca e na Margarida da Carvalhosa e na Ricort'” (SM, p. 626). Denunciando a corrupção e a libertinagem do pároco, o autor insere na obra um dos temas em voga na época, a crítica anticlerical - que já era feita pelos românticos, dentre os quais o próprio Camilo, mas que se tornou marca do romance realista/naturalista português com O Crime do Padre Amaro (1875), de Eça de Queirós.

Em determinado momento, temos o retrato vulgar da amizade entre uma personagem de O Senhor Ministro - Joana Gaitas - e Eufêmia Troncha, de A Corja. De acordo com o narrador, estas mulheres, "quando se encontravam nas romarias, beijocavam-se muito, davam-se sapatadas nos recíprocos ventres, chamavam-se gajas e contavam pândegas, banzés, maroteiras de fazer tremer o céu e a terra" (SM, p. 679, grifo do autor). Todavia, Joana Gaitas acaba envolvendo-se numa briga com outra mulher numa taverna, em uma cena repleta de palavras de baixo calão e comportamentos animalescos, de claro intuito paródico aos temas vulgares e grosseiros do naturalismo: 
- Cala-te aí, cala-te aí, grandíssima desavergonhada! O que tu precisavas era que te tapassem essa boca com uma pouca de bosta, cabra tinhosa!

- Ó seu cação, ouviu? [...] se você não fosse uma velha, torcia-lhe esse pescoço.

- Anda pra cá, marafona do alto, que te pespego com esta soca na porca da cara. $[\ldots]$

- Estas carcaças não há uma peste que as lamba [...].

- Agora, vai cozê-la, anda, vai cozê-la, grande porca! - resmungou [...], esgaravatando [...] nas costuras do saioto as luras das pulgas.

- Ó estupor! que te esgano! - replicou a outra, atirando-se-lhe de salto ao pescoço.

A velha engadilhou-se-lhe no cabelo e desatou a berrar [...]. (SM, p.682$683)$.

Assim sendo, numa outra passagem, em que descreve a reabilitação de Tibúrcio após este deixar da vida vadia e dissoluta, o narrador camiliano critica o discurso naturalista através da ridicularização do cientificismo e da medicina como explicação para o comportamento humano:

Como se operou esta subitânea transformação? O doutor Wigan, citado por Maudsley, diz que mudara a condição de um rapaz, aplicando-lhe sanguessugas ao nariz. Pois ninguém se persuada que Tibúrcio passasse pela cruenta prova da sangria nasal. A ciência nova carece destes expedientes de doutor Sangrado para explicar tais reformas por modalidades orgânicas. (SM, p. 663).

Contudo, é importante ressaltarmos que a aclamação do discurso romântico é apenas aparente. É irônico o trecho seguinte, em que o narrador afirma que "os velhos metafísicos explicavam estas mudanças radicais na condição do indivíduo com a palavra mulher, e tinham para tudo que era extraordinário o moderno cherchez la femme" (SM, p. 663, grifo do autor). Como o leitor sabe, nesse ponto da narrativa, a regeneração de Tibúrcio não foi provocada pela medicina nem pelo amor, mas sim pelo dinheiro - ou melhor, pela falta dele, o que o fez interessar-se pela fortuna do tio de Amália. Se seu pai tivesse continuado a sustentar a sua vida ociosa e libertina, o seu namoro com Amália não teria passado de mais uma aventura. 
Assim sendo, Camilo não critica o discurso naturalista com o intuito de defender o romântico. Pelo contrário, o romantismo é também parodiado no relato dos namoros de Amália e suas irmãs: "Entre 1840 e 46 não foi a Coimbra Lamartine subalterno que as não cantasse no estilo doentio de então. Solaus e madrigais. Um ideal de castelãs medievas, com umas rimas tão perfumadas de petrarquismo que nem elas tinham olfato capaz de sentir o insidioso azote filtrado nos bagos de mirra" (SM, p. 627). No começo da história, Amália queixa-se do linguajar romântico utilizado pelos rapazes "poetas" para enganar as moças:

- Maganão! alanzoa para aí... Cuidas que te não percebo? Já não engulo araras, menino. Falo-te em alhos, respondes-me em bugalhos. O que tu queres é passar tempo. Vens barrado. Alicantinas, não? Chiam todos a mesma cantiga. É como diz a mana Rosa: estilo e mais estilo. Ela é que sabe responder a essas perlengas. Eu cá não aprendi a namorar pelos livros. Quando me mandam versos, mudo de rumo, e desconfio logo que me querem lograr... (SM, p. 621, grifo do autor).

Por outro lado, o interesse financeiro das moças casadouras é também criticado por Camilo, que já via de forma negativa, desde os seus primeiros romances, o excesso de materialismo na sociedade portuguesa. Amália e suas irmãs, nativas de Coimbra - berço, aliás, da "Geração Nova" -, são caracterizadas pelo narrador como calculistas e interesseiras:

Não há em Portugal mais tristes, mais canhestras, mais despoetizadas senhoras que as de Coimbra. Todas aquelas fisionomias argilosamente duras que recebem a viração balsâmica do Jardim Botânico como estátuas de pedra de Ançã, parece que têm na cara a matemática, e no coração aquilo simplesmente que a anatomia lhes atribui. [...] Almas formadas de luar e trilos de rouxinol, ou indivíduos que fizeram a sua encerebração na broa e nos farináceos provinciais, são para elas duas coisas idênticas ensacadas em umas batinas semelhantes. Ali não há ilusões, esperanças desvanecidas senão as das loterias. Não há quem iluda cegamente, generosamente crente, nem quem se deixe iludir. São comtianas, litreistas $a b$ ovo aquelas senhoras que pareceriam abóboras-meninas mecânicas, se não estivessem cheias de juízo e positivismo. Não consta que aí houvesse uma paixão desastrosa - uma mulher que resvalasse aos braços dum amante pela rampa madrigalesca de um soneto. Vem de longe o positivismo. Sá de Miranda cantou e chorou copiosamente a Délia, e António Ferreira a Serra. Ambos logrados. A primeira não acreditou que o filho do cônego Gonçalo chegasse a 
comendador; a outra nunca imaginou que o seu infatigável soneteiro chegaria a desembargador do cível. (SM, p. 656, grifo do autor).

Neste trecho, o narrador mostra que o materialismo das "despoetizadas senhoras de Coimbra", que só se atêm à ciência matemática - ou seja, ao cálculo do interesse financeiro - e à ciência fisiológica da anatomia - isto é, não há sentimentos de amor verdadeiro em seus corações -, não é exclusivo dos seguidores do positivismo de Comte e Littré, mas já existia desde a época de Sá de Miranda (1481-1558) e António Ferreira (15281569). Assim, Camilo desmerece a "novidade" da escola realista/naturalista, apontando que não se trata de um discurso original: afinal, é só "pôr a fisiologia onde os românticos punham a sentimentalidade" e "subordinar à fatalidade o que, pelos velhos processos, se imputava à educação e à responsabilidade" (Cf. EM, p. 463-464), como ele afirmara no prefácio à segunda edição de Eusébio Macário, discutido por nós anteriormente.

Entretanto, a análise do final do romance nos faz depreender uma visão inusitada de Camilo sobre as questões levantadas pela "nova geração". Quando Tibúrcio, após o seu mandato de deputado - em que percebeu que "neste dilúvio de porcaria, as bestas eram tantas e a arca tão pequena que afinal não se salvava ninguém, por causa das bestas" (SM, p. 688) -, afirma a sua vontade de ser ministro para "salvar a nação" (Cf. $S M$, p. 687), uma vez que "este país gangrenado ainda podia salvar-se com uma grande amputação" (SM, p. 688), o seu tio cônego lhe responde: "Mas que diabo tem o país?! Ninguém lá por fora me cheira a gangrena. Reinam os reumatismos e os catarros; mas, quanto à podridão, não sei de nenhuma, fora dos hospitais. Eu, se fosse a ti, meu Tibúrcio, não amputava nada, sendo ministro" (SM, p. 688.). Nestas duas falas, podemos encontrar dois usos diferentes do discurso naturalista.

Na fala de Tibúrcio, a metáfora médica está a serviço da denúncia da corrupção do país, onde os cargos políticos mais altos só são alcançados pela compra de votos do povo, pela bajulação dos que têm dinheiro e pela entrada em ordens religiosas influentes no 
governo, o que o protagonista se nega a fazer, mesmo quando é eleito ministro da Ordem Terceira de S. Francisco, por arranjo do tio cônego. Como o narrador explica,

O doutor não transigia com os maus hábitos da mendicidade. Se ele queria jarretar excrescências canceradas no organismo nacional, o mais podre dos membros era a corrupção do sufrágio por meio de dinheiro aos pobres ou de abjeções aos ricos. Demais a mais, o insinuar-se nas irmandades parecia-lhe carolice estúpida ou hipocrisia canalha. (SM, p. 689).

Já na fala do pároco, vemos o uso de termos médicos e fisiológicos não de forma metafórica, mas literalmente, o que mostra a cegueira do personagem, que só percebe a presença das doenças físicas, e não os problemas políticos e sociais de Portugal. Assim, Camilo parece criticar a superficialidade, a seu ver, do naturalismo - presente nas teses cientificistas e suas manifestações na literatura -, defendendo uma visão realista da sociedade, não vinculada à nova estética, mas a uma análise crítica da realidade social, tal como, aliás, ele sempre fez. Como José Cândido Martins afirma acerca de Eusébio Macário e A Corja, o autor pretende denunciar que "um realismo das coisas, ou realismo epidérmico, da estética realista [naturalista], postergava para segundo plano um realismo das almas, ou realismo de profundidade" (2003, p. 35, grifo do autor). De acordo com o crítico, "é justamente esta pretensão científica e até experimental, esta associação mecanicista e algo ingênua da Ciência à Literatura, com vários excessos ao nível estilístico, temático [...] e ideológico que Camilo censurará de modo violento e galhofeiro, através de mordaz ofensiva paródica" (2003, p. 21). Analisemos o último parágrafo de $O$ Senhor Ministro, precedido do título "MORALIDADE":

Se o Dr. Tibúrcio exercitasse dignamente as funções de Ministro da Venerável Ordem Terceira de S. Francisco, poderia subir pela escada de Jacob às eminências do ministério divino como o próprio S. Francisco; e lá na mansão celeste se encontraria, não direi com a Severa, mas com alguns monarcas lusitanos que, à imitação de D. Pedro, o Cru, também pertenceram à Ordem Terceira do referido santo. Mas o Dr. Tibúrcio Pimenta, que principiava a combalir-se das podridões modernas, nunca foi ministrar a 
Ordem Terceira; e aquela D. Amália, gafada das incredulidades coimbrãs afirmadas depois pela falange deicida de Antero do Quental - quando disse "ora bolas!" [no momento em que percebe que o convite que o marido recebera não era para ser ministro de Estado, mas sim ministro da irmandade religiosa] definiu perfeitamente a sua geração e tolheu talvez o futuro do marido. (SM, p. 691, grifo do autor).

Após toda a crítica anticlerical tecida pelo autor ao longo da narrativa, é possível depreendermos que o parágrafo intitulado "Moralidade" se trata de uma ironia. Parece-nos claro que a atitude de Tibúrcio, ao rejeitar o compadrio da ordem religiosa, foi positiva, uma vez que a Ordem Terceira de S. Francisco é caracterizada de forma ironicamente crítica pelo narrador - no momento em que se refere ao monarca D. Pedro, Camilo ressalta o aposto "o Cru", destacando a sua crueldade, que não se coadunaria com as atitudes esperadas de um homem santo. Com isso, o narrador parece criticar a interferência da religião - ou, ao menos, desse tipo de religioso, hipócrita, corrupto e libertino como o padre João - na política nacional. Além disso, Tibúrcio não se deixou corromper pelas podridões da política, mesmo tendo-lhe custado o sonho de ser ministro de Estado. Dessa forma, a proposta ideológica da "nova geração", representada pela "falange deicida de Antero do Quental”4, de salvar o país através da "amputação" dos hábitos corruptos na política, não é criticada por Camilo, mas lamentada por ser um ideal inatingível, como vemos na fala do protagonista:

Não sejas criança. Homens da minha inflexível independência só podem ser ministros, se o povo e as armas os impõe ao Poder Moderador. A minha coluna vertebral não se curva nem ao povo, nem aos argentários, nem à camarilha. Nunca passarei de bacharel Tibúrcio Pimenta, natural da Gandarela, e advogado nos auditórios do Porto. (SM, p. 689).

\footnotetext{
${ }^{4}$ Apesar de ser visto - não somente por Camilo como também por outros críticos e intelectuais dos séculos XIX e XX - como o ideólogo da "Geração Nova", Antero de Quental não se coadunava com o ímpeto cientificista da escola naturalista. Como lembra Maria Helena Santana, "vale a pena atentar na posição crítica de Antero, exposta num conjunto de artigos sob o tema 'A filosofia da natureza dos naturalistas', já que se coloca em clara oposição à euforia cientista dominante. No seu conjunto, o ensaio apresenta uma refutação fundamentada não apenas da doutrina monista, mas de toda a filosofia construída sobre matéria científica." (2007, p. 53).
} 
Assim sendo, para Camilo, os ideais da "Geração Nova” são louváveis, porém, ingênuos - e isso só poderia ser percebido deixando-se de se ater ao superficial, o cientificismo, e analisando de forma mais crítica a sociedade. Segundo Cândido Martins, "a estética realista-naturalista advoga para arte uma finalidade didática e reformista: o retrato fidedigno da realidade tinha como grande objetivo a morigeração dos costumes - o espelho mostrando os vícios e a decadência seria o melhor instrumento de moralização social” (1997, p. 49, grifo do autor). Entretanto, como o crítico explica, “discordando desta funcionalidade atribuída à arte romanesca, Camilo não hesita [...] em subverter esta pretensa moralidade do romance, mostrando a insensatez, ineficácia ou mesmo inanidade dessas convicções naturalistas [...]. Portugal era um país perdido, impossível de regenerar” (1997, p. 49). Nas palavras do romancista, dirigidas em 1881 a Alexandre da Conceição,

[...] se cotejo as novelas modernas com os praxistas sociológicos em que se estriba a estética da última hora, persuado-me que esses romances podem fazer-se com observação e estilo sem que aos autores urja a necessidade imprescindível de manusearem a Biologia de Herbert Spencer, a Evolução Humana de Haeckel e o Positivismo de Comte. Para que há de assoprar com tamanho empirismo de ciências pingues uma coisa tão oca e fútil como a novela? (Apud CABRAL, Alexandre, 1982, p. 108).

Dessa forma, além de não acreditar no papel da literatura, "oca e fútil”, como um instrumento regenerador da nação, Camilo critica o discurso naturalista, denunciando a inadequação das teorias científicas para a explicação dos mecanismos que movem a sociedade. Para ele, era justamente nessa utilização sistemática do cientificismo que a "Geração Nova" se equivocava, apesar das suas louváveis intenções de reforma social - o fato, porém, de criticar o naturalismo não o levava necessariamente, como vimos, a elogiar o discurso romântico. Como o autor defende em O Senhor Ministro, só é possível compreender as mazelas da sociedade portuguesa a partir de um olhar destituído de ilusões, tanto sentimentais, quanto científicas: um olhar mais atento à realidade social, portanto. 


\subsection{As Vítimas-Algozes e a escravidão que caleja, petrifica e mata o coração do homem}

Por ter sido publicada por Joaquim Manuel de Macedo em 1869, As VítimasAlgozes: quadros da escravidão é considerada por parte da crítica uma obra pré-naturalista, uma vez que teria sido lançada numa época anterior à determinada pela historiografia literária como o "início" do realismo/naturalismo brasileiro. Segundo Tania Serra, "[...] poder-se-ia, com As vítimas-algozes, por alguns aspectos de sua temática e pela escolha do campo léxico, fazê-las antecipar em oito anos o pré-Naturalismo no Brasil (O coronel sangrado, de Inglês de Sousa, é de 1877)” (2004, p. 153-154).

Apesar de não nos coadunarmos com as divisões rígidas da história literária, concordamos com a pesquisadora em sua defesa de que "Thérèse Raquin (1867) e Madeleine Férat (1868) provavelmente não foram lidos por Macedo. Mas o que importa aqui não é mostrar a influência de Zola sobre nosso romancista, pois penso que não a houve, mas, sim, mostrar COMO Macedo chegou à prosa pré-naturalista d'As vítimas-algozes" (2004, p. 155, grifo da autora). Para Serra, isso teria acontecido "por intermédio de Hugo e Sue, como afirma [Otto Maria] Carpeaux ter ocorrido com Zola ${ }^{5}$ [...]. À influência literária alie-se o momento histórico do país, em fase de grande movimentação abolicionista" (2004, p. 155) - a obra foi publicada dezenove anos antes da abolição da escravatura (oficializada com a Lei Áurea, de 1888), em meio a uma discussão nacional sobre a Lei do Ventre Livre, que acabou sendo promulgada dois anos depois, em 1871.

\footnotetext{
${ }^{5}$ Como Serra explica, "[...] aproveitando os ensinamentos de Hugo e Sue, [Macedo] usou em sua obra algumas ideias novas: o determinismo social, a denúncia dos sofrimentos dos baixos extratos da população e a descrição 'didática' do vício, do sexo, da lama, da perfídia, etc. Todas características do Naturalismo, ramo do Realismo que, pelo menos no caso de Zola, segundo pensa Carpeaux [no volume VI da História da Literatura Ocidental], é herdeiro do romantismo de Hugo e do folhetim dramático de Sue.” (2004, p. 154).
} 
Além disso, como procuramos demonstrar anteriormente, teorias científicas tais como a hereditariedade e o darwinismo social - com as quais, veremos a seguir, Macedo, de certa forma, dialogou em As Vítimas-Algozes - já eram difundidas no Brasil muitos anos antes da "data oficial" do "início" do realismo/naturalismo na literatura brasileira. Como é possível verificar na crítica negativa que o anônimo "Dr. Pancrácio", publicada na Vida Fluminense em 8 de janeiro de 1870, faz ao romance macediano, o termo "realista" já era utilizado, nesse momento, para designar a nova estética: “Certas descrições são feitas demasiado ao vivo, e há cenas verdadeiramente repugnantes. É levar muito longe a escola realista” (Apud SERRA, 2004, p. 160-161).

A obra macediana traz, assim, três histórias nas quais os protagonistas são escravos que infligem algum mal a seus senhores. Na primeira, "Simeão, o crioulo", assassina toda a família; na segunda, "Pai-Raiol, o feiticeiro", manipula a escrava doméstica para envenenar a esposa e os filhos do fazendeiro; na terceira, "Lucinda, a mucama", alia-se a um sedutor que procura forçar um casamento com a sinhá-moça e o auxilia a se aproximar da donzela para violentá-la. Nas três narrativas, encontramos a presença da descrição grosseira e animalizada desses escravos. Nas palavras de Tania Serra, nelas podemos

[...] observar algumas características da prosa naturalista: o homem-animal, condicionado socialmente pela hereditariedade ${ }^{6}$ da escravidão, fato ignóbil, e que deve ser abolido, e a visão da lubricidade humana. Ideias-chave veiculadas numa frase carregada, cheia de hipérboles, com um léxico escolhido especificamente no campo semântico do vício [...]. (2004, p. 158).

Sobre Simeão, por exemplo, é dito que "com os escravos mais brutais e corruptos, e com os vadios, turbulentos e viciosos das vizinhanças entregou-se a todos os deboches, e se

\footnotetext{
${ }^{6}$ A nosso ver, Macedo não se coadunava com as teorias da hereditariedade racial, fato que iremos discutir mais adiante.
} 
fez sócio ativo do jogo aladroado, da embriaguez ignóbil e da luxúria mais torpe” (VA7, p. 20). Já a mucama “era levada [...] pelo império que sobre ela tinha o demônio da luxúria [...]; só respirava lascívia em desejos, ações e palavras de fogo infernal: sua natureza era sob este ponto de vista impetuosa, ardente e infrene" (VA, p. 178). A descrição de Pai-Raiol, por sua vez, é longa e grotesca:

[...] homem de baixa estatura, tinha o corpo exageradamente maior que as pernas; a cabeça grande, os olhos vesgos, mas brilhantes e impossíveis de se resistir à fixidade do seu olhar pela impressão incômoda do estrabismo duplo, e por não sabermos que fluição de magnetismo infernal; quanto ao mais, mostrava os caracteres físicos da sua raça; trazia porém nas faces cicatrizes vultuosas de sarjaduras recebidas na infância: um golpe de azorrague lhe partira pelo meio o lábio superior, e a fenda resultante deixara a descoberto dous dentes brancos, alvejantes, pontudos, dentes caninos que pareciam ostentar-se ameaçadores; sua boca era pois como mal fechada por três lábios; dous superiores e completamente separados, e um inferior perfeito: o rir aliás muito raro desse negro era hediondo por semelhante deformidade; a barba retorcida e pobre que ele tinha mal crescida no queixo, como erva mesquinha em solo árido, em vez de ornar afeiava-lhe o semblante; uma de suas orelhas perdera o terço da concha na parte superior cortada irregularmente em violência de castigo ou em furor de desordem; e finalmente braços longos prendendo-se a mãos descomunais que desciam à altura dos joelhos completavam-lhe o aspecto repugnante da figura mais antipática. (VA, p. 82).

O teor negativo de tais descrições do caráter e do aspecto físico dos escravos, juntamente com o relato da crueldade com que destroem a vida de seus senhores, possui o claro propósito de não apenas horrorizar o leitor, como principalmente de aterrorizá-lo. Como explicam Gabriela Luft e Juliane Welter, o que predomina em As Vitimas-Algozes é "[...] o pânico senhorial, já que na época de publicação da obra eram constantes as discussões em torno do crescimento das fugas, furtos e crimes de cativos contra proprietários e feitores" (2009, p. 8). De acordo com as autoras, “o pânico era justificado, pois a resistência escrava

\footnotetext{
7 Ao longo deste trabalho, adotaremos a sigla VA sempre que citarmos o romance As Vítimas-Algozes, de Joaquim Manuel de Macedo. As citações são retiradas da $3^{a}$ edição publicada pela Editora Scipione (1991).
} 
cresceu entre as décadas de 60 e 70 do século XIX" (2009, p. 13) ${ }^{8}$. É a apologia do “imaginário do medo”, definida por Flora Süssekind em seu prefácio à obra de Macedo. Dirigida aos proprietários, segundo a pesquisadora, supostamente sem "grandes disfarces humanistas" (1993, p. 121), as narrativas foram escritas com o intuito de servir como propaganda abolicionista, possivelmente a pedido do próprio D. Pedro II, “a fim de preparar o público para a Lei do Ventre Livre”, como sugere David Brookshaw (1983, p. 33) ${ }^{9}$.

Feita para convencer o leitor da necessidade urgente da abolição da escravatura o que por si só, a nosso ver, já configuraria um propósito humanista -, a obra apela não para a compaixão do seu leitor, o senhor de escravo - algo que surtiria pouquíssimo efeito, pois a base da própria instituição escravocrata é erigida pela ausência de tal sentimento -, mas para o temor de que os escravos se voltem contra ele: afinal, pintar algozes é mais eficaz do que pintar vítimas. Como o autor afirma, na veemente voz do personagem que conclui o livro, "a escravidão é peste; por que não nos havemos de libertar da peste? [...] Bani a escravidão! Bani a escravidão! Bani a escravidão!...” (VA, p. 314). Em seu prefácio, Macedo explica os motivos que o levaram a retratar os escravos como seres "ferozes":

Seguindo dous caminhos opostos, chega-se ao ponto que temos fitado, à reprovação profunda que deve inspirar a escravidão.

Um desses caminhos se estende por entre às misérias tristíssimas, e os incalculáveis sofrimentos do escravo, por essa vida de amarguras sem termo, de árido deserto sem um oásis, de inferno perpétuo no mundo negro da escravidão. É o quadro do mal que o senhor, ainda sem querer, faz ao escravo.

O outro mostra a seus lados os vícios ignóbeis, a perversão, os ódios, os ferozes instintos do escravo, inimigo natural e rancoroso do seu senhor, os miasmas, deixem-nos dizer assim, a sífilis moral da escravidão infeccionando a casa, a fazenda, a família dos senhores, e a sua raiva concentrada, mas sempre em conspiração latente atentando contra a fortuna, a vida e a honra dos seus incônscios opressores. É o quadro do mal que o

\footnotetext{
${ }^{8}$ Para maiores informações sobre a resistência escrava e o clima de pânico que pairava entre os fazendeiros, ler a monografia de Eduardo da Cruz, Sobre Vítimas e Algozes: Joaquim Manuel de Macedo e a escravidão no século XIX, defendida na Universidade Federal do Paraná em 2011.

${ }^{9}$ De acordo com um excerto retirado do jornal A Província de São Paulo, de 10 de janeiro de 1880, "dizem que quando o imperador empenhava-se pela libertação do ventre livre escravo pediu a um afamado escritor de seu tempo para escrever alguma coisa em favor dessa ideia” (Apud BROOKSHAW, 1983, p. 33).
} 
escravo faz de assentado propósito ou às vezes involuntária e irrefletidamente ao senhor.

Preferimos este segundo caminho: é o que mais convém ao nosso empenho. Esquecemos o Bug-Jargal ${ }^{10}$, o Toussaint Louverture ${ }^{11}$ e o Pai-Simão ${ }^{12}$; o escravo que vamos expor a vossos olhos é o escravo de nossas casas e de nossas fazendas, o homem que nasceu homem, e que a escravidão tornou peste ou fera. (VA, p. 4-5).

Embora opte por mostrar em sua obra o escravo "tornado peste ou fera", Macedo não discorda da literatura que denuncia as "misérias tristíssimas" dos negros, representada, por exemplo, pelo romance A Cabana do Pai-Tomás (1851-1852) de Harriet Beecher Stowe. Como um dos personagens macedianos defende fervorosamente, ao comentar sobre a obra da escritora norte-americana,

[...] este romance concorreu para uma grande revolução social; porque encerra grandes verdades [...]. As do contrassenso, da violência, do crime da escravidão de homens, como nós outros, que nos impomos senhores; as da privação de todos os direitos, da negação de todos os generosos sentimentos das vítimas, que são os escravos; as da insensibilidade, da crueldade irrefletida, mas real, e do despotismo e da opressão indeclináveis dos senhores. (VA, p. 200).

Contudo, concordamos com Sharyse Amaral, em sua defesa de que "é provável que dada a forma como Macedo entendera que as relações entre senhores e escravos foram estabelecidas no Brasil, ele não acreditasse em verdadeira mudança no quadro social apenas apelando para a humanidade dos senhores" (2001, p. 61). Nas palavras da pesquisadora, “parece óbvio que o autor seria muito mais persuasivo se apelasse para o próprio egoísmo do

\footnotetext{
10 "Herói do romance de mesmo nome, de Victor Hugo, [...] publicado em 1821, cuja ação se passa em São Domingos durante a revolta dos negros pelo fim da escravidão, em 1791. O escravo Bug-Jargal é um dos líderes da conspiração" (Cf. nota escrita por Rachel Teixeira Valença na edição utilizada por nós).

11 "Negro haitiano que teve importante participação na única revolta vitoriosa de escravos de que se tem notícia, na parte francesa da ilha de São Domingos, em 1791” (Cf. nota de Rachel Valença).

${ }^{12}$ A nota de rodapé informa que "sobre Pai-Simão não se localizou qualquer referência".
} 
senhor, mostrando que o escravo não seria o único prejudicado pela perpetuação da escravidão no Brasil” (2007, p. 202).

Com isso, "ao narrar histórias de escravos dissimulados, depravados, ladrões e assassinos, à primeira vista pode parecer-nos que o autor está carregando nas características pejorativas do negro, porém, em uma leitura mais atenta, fica claro que Macedo descreve pejorativamente a figura do escravo" (AMARAL, 2007, p. 202, grifo da autora). O que nos chama a atenção, nas descrições feitas pelo narrador macediano acerca dos escravos, anteriormente citadas, é o fato de ele fazer questão de relacionar a sua deformidade física e moral não à raça, mas sim à condição de escravo: como o narrador afirma, ao tratar de Simeão,

Fora absurdo pretender que a ingratidão às vezes até profundamente perversa dos crioulos amorosamente criados por seus senhores é neles inata ou condição natural da sua raça: a fonte do mal, que é mais negra do que a cor desses infelizes, é a escravidão, a consciência desse estado violenta e barbaramente imposto, estado lúgubre, revoltante, condição ignóbil, mãe do ódio, pústula encerradora de raiva, pantanal dos vícios mais torpes que degeneram, infeccionam, e tornam perverso o coração da vítima, o coração do escravo. (VA, p. 17).

A história de Simeão, escravo "amorosamente criado por seus senhores" - em gratidão à sua mãe, que fora ama de leite da filha do fazendeiro -, que acaba por matar toda a família, é posta de forma a "desmontar qualquer argumento escravista para justificar a manutenção da escravidão, tentando mostrar que nem a tolerância, nem a repressão [...] poderiam vir a conter a 'vingança' dos escravos, fosse ela deliberada ou não" (AMARAL, 2007, p. 222-223). Nas palavras de Eduardo da Cruz, “[...] não existia uma escravidão 'benéfica' - como seria a de Simeão, criado com carinho pela família senhorial. Todos os tipos de escravidão corrompiam o escravo e tornavam os senhores vítimas potenciais" (2011, p. 22). 
O sensualismo de Lucinda, por sua vez, é explicado a partir do meio em que ela nasceu, e não a partir da hereditariedade de sua raça: "A escrava abandonada aos desprezos da escravidão, crescendo no meio da prática dos vícios mais escandalosos e repugnantes [...], desde a primeira infância testemunhando torpezas de luxúria, [...] fica pervertida muito antes de ter consciência de sua perversão" (VA, p. 177). Quanto à descrição grotesca de Pai-Raiol, Flora Süssekind a interpretou como uma reprodução dos preconceitos de raça da época: "Pai Raiol funciona como uma espécie de paradigma de um negro só negro. De um quase ‘monstro', portanto, para olhos que se querem brancos, só brancos. E enxergam sua diferença como deformidade, exagero, desproporção, feiura" (1993, p. 128). Entretanto, como explica Sharyse Amaral,

Devemos perceber que os caracteres físicos naturais, a que aludiu Süssekind, não foram vinculados por Macedo à africanidade de Pai-Raiol, caso contrário, não teria escrito, poucas linhas depois, que "quanto ao mais, mostrava os caracteres físicos de sua raça" [Cf. VA, p. 82]. Deste modo, caracteres físicos pessoais atribuídos a Pai-Raiol são potencializados por qualidades advindas do fato de ser ele um feiticeiro (fixidade do seu olhar; fluição de seu magnetismo infernal) e, além disto, já bastante marcado pelos castigos da escravidão (cicatrizes vultosas na face; lábio deformado). (2007, p. 219, grifo da autora).

Amaral reforça o seu argumento ao lembrar o contraste entre a figura de Pai-Raiol e a de Tio Alberto, o escravo que salva o fazendeiro de ser morto pelo feiticeiro. Como ela aponta, Tio Alberto é "um personagem que trabalhava 'assíduo e diligente para escapar ao castigo que se ufanava de nunca ter provado' [VA, p. 131]. Porém, também não podemos esquecer que este era 'bonito para a sua raça' [VA, p. 128]”' (2007, p. 219). De bom coração não gostava de Pai-Raiol porque este matara "por maldade" sua cachorrinha, fato que contou com "duas lágrimas" rolando por sua face (Cf. VA, p. 129) -, o escravo é descrito da seguinte forma por Macedo: 
O tio Alberto representava o contraste mais completo do Pai-Raiol: era um escravo africano [...] de alta estatura; tinha a fronte elevada, os olhos grandes e brilhantes, a cor preta um pouco luzidia, os dentes brancos e perfeitos, largas espáduas, grossos e bem torneados braços possantes e formas justamente proporcionais: era bonito para a sua raça, um Hércules negro em suma. (VA, p. 128).

Além disso, na descrição de Simeão, o narrador afirma que "era um crioulo de raça pura africana, mas cujos caracteres físicos aliás favoravelmente modificados pelo clima e pela influência natural do país onde nascera [Brasil], não tinham sido ainda afeiados pelos serviços rigorosos da escravidão" (VA, p. 15). Apesar de se utilizar dos preconceitos cientificistas difundidos na época, acerca da "melhora da raça" por influência do clima brasileiro, Macedo especifica que Simeão não tinha aspecto desagradável porque não tinha sido "afeiado pelos serviços rigorosos da escravidão". Ou seja, para o autor, o que torna o escravo repugnante não é a sua raça, mas o sofrimento dos trabalhos forçados.

Em alguns momentos, contudo, o preconceito racial parece de fato aflorar, como no trecho apontado por Süssekind (Cf. 1993, p. 131-132), em que o narrador afirma que “Teresa não era uma senhora formosa; mas, posta mesmo de lado a superioridade física de raça, era bem-feita, engraçada e mimosa de rosto e de figura a não admitir comparação com a crioula" (VA, p. 99). Embora reproduza o discurso preconceituoso da "superioridade física de raça", apregoado pelas teorias científicas racistas da época, devemos ter em conta o objetivo de Macedo, que se torna mais claro se analisarmos o parágrafo seguinte: "Todavia Esméria estava convencida de que era [...] muito mais bonita e elegante do que sua senhora. Essa petulante convicção é especialmente nas escravas crioulas mais comum do que se cuida. Os senhores imorais são muitas vezes os culpados de semelhante presunção" (VA, p. 99-100). Neste período, Macedo mostra que os culpados pelas relações entre os senhores e suas escravas, que promoviam a desestruturação das famílias, a ponto de colocar em risco a vida das esposas, são os próprios senhores, a quem a crítica é dirigida. 
Assim sendo, “[...] o senhor deveria se reconhecer como o verdadeiro responsável pela criminalidade dos escravos, já que, no discurso de Macedo, a perversão é atribuída à escravidão e não à raça negra" (AMARAL, 2001, p. 67). Com isso, "por ser uma obra de propaganda a favor da emancipação escrava em que Macedo apelava para os interesses da família do senhor, nela, mais do que em nenhuma outra obra, Macedo adotou o ponto de vista senhorial" (AMARAL, 2001, p. 92). Dessa forma, utilizando-se do ponto de vista (preconceituoso) dos proprietários - caracterizados pelo narrador como bons e honrados, que acabam sendo cruéis para com os escravos "sem querer" ou "sem perceberem", como vimos, aliás, no prefácio -, o autor constrói uma estratégia retórica de identificação com o leitor, que acaba sendo mais persuasiva do que se tentasse apelar para o espírito humanitário dos senhores, descrevendo-os como vilões e os escravos como pobres vítimas.

Por outro lado, Flora Süssekind critica o fato de Macedo rejeitar a escravidão com “olhos de negociante" (Cf. 1993, p. 121), sugerindo que "a emancipação deveria partir dos próprios fazendeiros e proprietários. E não a troco de nada. Com indenização. E substituindose a mão de obra escrava e velhos métodos de plantio por uma modernização inevitável, louvável e muito mais lucrativa" (1993, p. 121). E acrescenta, censurando o autor: "nada de permitir a conscientização 'inteligente' dos oprimidos ou quaisquer vinganças, veladas ou ferozes" (1993, p. 121). Segundo o prefácio de As Vítimas-Algozes,

[...] a escravidão, que é cancro social [...], é também ainda assim instrumento de riqueza agrícola, manancial do trabalho dos campos, dependência de inumeráveis interesses, imenso capital que representa a fortuna de milhares de proprietários [...].

A emancipação imediata e absoluta dos escravos [...] seria louco arrojo que poria em convulsão o país, em desordem descomunal e em soçobro a riqueza particular e pública, em miséria o povo, em bancarrota o Estado.

A emancipação gradual iniciada pelos ventres livres das escravas, e completada por meios indiretos no correr de prazo não muito longo, e diretos no fim desse prazo com indenização garantida aos senhores, é o conselho da prudência e o recurso providente dos proprietários. (VA, p. 3-4, grifo do autor). 
Aqui, mais uma vez, devemos atentar para qual público leitor Macedo dirige a sua obra: obviamente não é o escravo e, portanto, defender a sua conscientização seria inócuo. Mais eficaz seria apelar para aquilo que realmente move o proprietário - o dinheiro -, fazendo-o acreditar que, além de não sair prejudicado, poderia ainda ter mais lucro com a extinção do sistema escravocrata. Na narrativa, contudo, é possível encontrarmos também a preocupação com o destino dos escravos depois de libertos: “[...] mas com os diabos! Se morrer o velho, a liberdade que ele te vai deixar tem ares de benção seguida de pontapé! [...] Não te mandaram ensinar ofício, fizeram de ti um famoso vadio, [...] e agora se vieres a ficar forro, escorregarás da alforria para a miséria... hem?..." (VA, p. 37). De acordo com Sharyse Amaral, nesta passagem o narrador faz "uma profunda crítica à sociedade em que vivia, pois, ao mostrar que o liberto sem trabalho poderia vir a viver em uma situação pior do que a de escravo, o autor trazia à tona o problema da população livre, desempregada [...]. Atentando para isso, mostra a necessidade de se educar o escravo [...]” (2001, p. 76).

Atento, portanto, ao ponto de vista de seu leitor, e utilizando-se deste para persuadi-lo, Macedo constrói uma obra abolicionista que, por outro lado, contraria o discurso em voga na época. Baseado nos ideais cientificistas do darwinismo social, o determinismo da raça estava na pauta das discussões - e, assim, a escravidão era justificada por uma suposta “inferioridade" do negro ${ }^{13}$. O estereótipo, por exemplo, "do mulato incuravelmente sensual e vingativo era mais explicado em termos biológicos pela derivação de uma instabilidade orgânica do que atribuído à sua posição insegura na estrutura social” (BROOKSHAW, 1983, p. 52). Amaral lembra que "a argumentação de Macedo em muito se diferencia das doutrinas

\footnotetext{
13 Segundo David Brookshaw, essa suposta “[...] incapacidade do negro podia ser explicada pela teoria darwiniana de seleção natural que enfatizava a grande diferença existente entre as variedades humanas, e pela ética liberal de Spencer da 'sobrevivência dos mais capazes', na qual o fraco estava inevitavelmente fadado a sucumbir em sua forçada competição com o forte.” (1983, p. 51).
} 
poligenistas $^{14}$. Isto pode ser percebido pelo fato de o narrador de As vítimas-algozes, por várias vezes, nas três novelas, caracterizar o negro, fosse ele africano ou não, como inteligente" (2007, p. 228).

Como analisamos anteriormente, a sensualidade da mucama é explicada pelo narrador a partir do meio em que ela cresceu, e não a partir de fatores biológicos: “ela é o que a fizeram ser, escrava, e consequentemente foco de peste; porque não pode haver moralidade, honra, culto do dever na escravidão, que é a negação de tudo isso. Que importa ao escravo o dever, se ele não tem direitos?" (VA, p. 268). Sobre a crueldade dos escravos, o narrador macediano afirma que "a sua ingratidão e a sua perversidade não se explicam pela natureza da raça, o que seria absurdo; explicam-se pela condição de escravo, que corrompe e perverte o homem" (VA, p. 18) - ou seja, “a escravidão gasta, caleja, petrifica, mata o coração do homem escravo" (VA, p. 53, grifo nosso). Assim, Macedo defende que, sem a condição de cativos, o homem e a mulher negros são seres iguais aos brancos, uma vez que, segundo ele, "a escravidão degrada, deprava, e torna o homem capaz dos mais medonhos crimes" (VA, p. 68); porém, "todos o sabem, a liberdade moraliza, nobilita, e é capaz de fazer virtuoso o homem" (VA, p. 67). Nas palavras de Amaral, “devemos ressaltar que Macedo mostrava uma oposição social entre escravos e senhores, e não racial. Era o escravo que era inimigo do senhor e não o negro que era inimigo do branco. Caso contrário, a liberdade não seria capaz de regenerar o escravo" (2001, p. 90).

\footnotetext{
${ }^{14}$ De acordo com Lilia Moritz Schwarcz, "a partir de meados do século XIX a hipótese poligenista transformava-se em uma alternativa plausível, em vista da crescente sofisticação das ciências biológicas e sobretudo diante da contestação do dogma monogenista da Igreja [para a qual 'a humanidade era uma' e 'o homem, segundo essa versão, teria se originado de uma fonte comum']. Partiam esses autores da crença na existência de vários centros de criação, que corresponderiam, por sua vez, às diferenças raciais observadas. A versão poligenista permitiria, por outro lado, o fortalecimento de uma interpretação biológica na análise dos comportamentos humanos, que passam a ser crescentemente encarados como resultado imediato de leis biológicas e naturais. Este tipo de viés foi encorajado sobretudo pelo nascimento simultâneo da frenologia e da antropometria, teorias que passavam a interpretar a capacidade humana tomando em conta o tamanho e proporção do cérebro dos diferentes povos [...]. Recrudescia, portanto, uma linha de análise que cada vez mais se afastava dos modelos humanistas, estabelecendo rígidas correlações entre conhecimento exterior e interior, entre a superfície do corpo e a profundeza de seu espírito." (1993, p. 48-49, grifo da autora).
} 
Segundo Antonio Candido, "na medida em que o problema é deslocado para dimensões tão vastas e incontroláveis como Natureza e Raça, o intelectual e o político perdem de vista a dimensão mais acessível, que são os aspectos sociais, onde está a chave” (2004, p. 118). Ao contrário de grande parte dos escritores naturalistas, no entanto, Macedo traz uma perspectiva distinta da encontrada no discurso cientificista vigente, apesar de basear a sua tese antiescravagista num certo determinismo social, como aponta Amaral (Cf. 2007, p. 210): o autor acaba, assim, deslocando o foco da questão racial para a questão social.

Com isso, Macedo reforça a sua crítica à sociedade brasileira, que ainda discutia sobre a abolição ou não da escravatura - para ele, não havia dúvidas de que o país deveria extinguir essa prática, e sua obra foi escrita para convencer o senhor de escravo a aderir à causa abolicionista. Diversamente de outros escritores românticos, contudo, que tencionavam mover a piedade do seu leitor, Macedo prefere aterrorizá-lo, uma estratégia retórica que, a seu ver, poderia ser mais eficaz. De maneira oposta à de muitos intelectuais do século XIX que, por sua vez, defendiam uma suposta "inferioridade" da raça negra, que justificaria a escravidão a partir de preconceitos biológicos e científicos, o narrador de As Vítimas-Algozes escolhe uma explicação social para as mazelas da escravidão - mostrando acreditar, assim, que é possível a plena inclusão do negro na sociedade brasileira. 


\section{Conclusão}

A opção de trabalhar com a ficção de dois autores que muito escreveram, como Camilo Castelo Branco e Joaquim Manuel de Macedo, trouxe-nos uma série de desafios, que nos levaram a buscar uma análise que englobasse uma parcela representativa de suas produções. Escritores de uma mesma geração - ambos nasceram na década de 1820, começaram a publicar nos anos 1840 e encerraram as suas carreiras na ocasião de suas mortes, entre as décadas de 1880 e 1890 -, Camilo e Macedo se aproximaram de muitas formas, ainda que, aparentemente, não tivessem dialogado entre si. Apesar de o escritor português ter sido muito lido no Brasil oitocentista ${ }^{1}$, não encontramos referências a ele na obra de Macedo. Já Camilo, no artigo intitulado "Literatura Brasileira", publicado no quarto número da publicação mensal Noites de Insônia (1874), provavelmente escrito para divulgar as publicações brasileiras da Livraria Internacional de Ernesto Chardron, apenas menciona brevemente, entre outros autores, o "fecundíssimo Joaquim Manuel de Macedo, que disputa a supremacia a J. de Alencar" (Cf. 1991, p. 896). Por isso, não foi nosso intuito aqui sugerir relações de influência ou diálogo entre eles, mas analisá-los paralelamente, pondo em relevo suas convergências, como forma de mostrar que os processos de ascensão do romance em Portugal e no Brasil não foram tão diferentes.

Se é verdade que os escritores brasileiros não apreciavam a concorrência dos portugueses, que, por sua vez, dependiam do mercado editorial de sua ex-colônia para vender

\footnotetext{
${ }^{1}$ Juliana Maia de Queiroz, em sua pesquisa no catálogo da Livraria Laemmert, uma livraria brasileira, de 1868, encontrou a presença de alguns autores portugueses, entre eles Camilo Castelo Branco (Cf. 2011, p. 60). Em diversos momentos, o autor menciona a sua relação com o mercado editorial brasileiro, como no preâmbulo de Coração, Cabeça e Estômago (1862), em que afirma - sinceramente ou ironicamente, não nos importa aqui determo-nos nisso - que "este prólogo foi escrito designadamente para ser impresso no Rio de Janeiro" (1984, p. 733), o que mostra a sua preocupação com as vendas do outro lado do Atlântico.
} 
os seus livros ${ }^{2}$, o fato é que a maior concorrência para os autores de aquém e além-mar eram decerto as obras produzidas nos centros do capitalismo europeu, principalmente as produções francesas (mas também as inglesas). Como explicamos no início deste trabalho, os romances franceses e ingleses não somente moldaram o gosto do público português e brasileiro, como também vendiam mais do que os escritores nacionais, que se viam obrigados a lidar com a "avalanche de obras originais ou traduzidas que vinham de Paris" (Cf. OLIVEIRA, 2008a, p. 177). Contudo, foi nosso objetivo, neste trabalho, defender que Camilo e Macedo, embora aparentem atender às expectativas de leitura do público moldadas pelos romances importados, acabaram na verdade questionando tais modelos, seja por meio da paródia - que, “com seu poder de carnavalização, [...] tem a força necessária e suficiente para exorcizar os fantasmas do colonialismo cultural que sistematicamente incomoda e preocupa os intelectuais de todos os lugares periféricos relativamente aos centros" (ALVES, J., 1990, p. 45) -, seja pelo desvio das temáticas e lugares-comuns mais utilizados, destacando-se pela "transgressão que se cria a partir de um novo uso do modelo pedido de empréstimo à cultura dominante", nas palavras anteriormente citadas de Silviano Santiago (1978, p. 58, grifo do autor).

É claro que não quisemos aqui afirmar que todos os romances franceses e ingleses eram feitos num só molde, reproduzindo as mesmas tópicas - é só lembrarmo-nos do

\footnotetext{
${ }^{2}$ Talvez não seja absurdo pensarmos que o sentimento de antilusitanismo que pairava no meio intelectual brasileiro não fosse movido apenas pelos ideais nacionalistas, mas também por uma disputa no mercado editorial. Como explica Eduardo Lourenço, "apesar da vontade, mais do que legítima, de reforço da sua identidade cultural, da invenção de mitos nativistas, o Brasil intelectual do século XIX é ainda muito português [...]. O Brasil continua a alimentar-nos [os portugueses] economicamente e é de lá que os nossos literatos célebres recebem as patacas que o pobre pai, sempre arruinado, não lhes fornece. Toda gente sabe como os Pinheiro Chagas, os Castilhos, os Ortigão, os Eça ou outros menores são então autores entre Portugal e o Brasil" (2001, p. 140, grifo do autor). Por outro lado, como Valéria Augusti observa, "com um público leitor diminuto e, provavelmente, dependendo do mercado consumidor de livros do Brasil para escoar a sua produção literária, não interessava aos homens de letras portugueses [...] ver a literatura brasileira prestigiada em suas terras. Isso explica, pelo menos em parte, os ataques sofridos pelos escritores brasileiros, assim como a parca recepção crítica de suas obras em periódicos portugueses do século XIX" (2004, p. 7). Essas questões, que não iremos aprofundar aqui, foram trabalhadas por nós no artigo "Romance, um gênero sem fronteiras: o mercado editorial luso-brasileiro", publicado nos Anais do XXIII Congresso Internacional da ABRAPLIP, realizado em São Luís em 2011, e no artigo "A literatura brasileira sob o olhar do escritor português oitocentista: pontes e polêmicas", a ser publicado nas Atas do $6^{\circ}$ Colóquio do PPRLB, Portugal no Brasil: pontes para o presente, realizado em 2012 no Rio de Janeiro, que se encontram no prelo.
} 
antirromance A Vida e as Opiniões do Cavalheiro Tristram Shandy (1759-1767), de Laurence Sterne, para ficarmos no exemplo mais célebre. Todavia, se podemos evocar várias obras não apenas produzidas no mundo lusófono, mas também na França e na Inglaterra - que parodiaram as convenções romanescas, é porque tais convenções, de fato, existiram, e foram certamente plasmadas nos centros do capitalismo europeu e exportadas para as periferias. Através da leitura de críticos da época, prefácios e excertos de obras, anúncios em periódicos do século XIX e estudos mais recentes, buscamos compreender quais seriam as expectativas de leitura do público oitocentista e quais seriam as características típicas mais valorizadas e apreciadas nos romances: quais seriam, portanto, os modelos que deveriam ser seguidos pelos escritores. Por isso, optamos por não estabelecer comparações entre as obras de Camilo e de Macedo e romances estrangeiros específicos: a nosso ver, os modelos com os quais os autores dialogaram são constituídos de estereótipos, lugares-comuns e expectativas de leitura, sendo muito difícil encontrar todas as suas características em uma única obra.

Além disso, apesar de estarmos cientes do caráter híbrido do romance, é certo que ele possui elementos que se sobressaem entre outros, o que permite ao público, baseado em sua experiência de leitura, identificar uma obra como pertencente a determinado subgênero. A escolha de trabalhar com os subgêneros do romance foi feita de maneira a não só alcançar uma visão panorâmica e mais abrangente da extensa ficção camiliana e macediana, como também a contribuir para uma maior compreensão do gênero romance, em sua variedade e complexidade, no século XIX: como muito bem definiu Franco Moretti, em sentença já mencionada por nós, "o romance é, em suma, o conjunto dos seus subgêneros" (2008, p. 57, grifo do autor). Sendo assim, procuramos selecionar obras de Camilo e de Macedo que se autointitularam ou foram recebidas como representantes desses subgêneros, mas que, numa análise mais atenta, apresentam aspectos que os distanciam de seus pressupostos estéticos. 
Começando pelos best-sellers Amor de Perdição e A Moreninha, buscamos mostrar que neles os autores, apesar de retratarem histórias de amor típicas dos romances sentimentais - o primeiro é composto por um enredo trágico de amor contrariado, e o segundo pela evolução de um amor de infância que acaba em casamento -, acabam por fim revelando, através da voz de seus narradores, o caráter postiço desse sentimentalismo exacerbado, posto de forma a agradar o leitor que apreciava esse tipo de narrativa. Os lugares-comuns da linguagem sentimental são, por diversas vezes, ridicularizados por esses narradores, que a todo o momento rebaixam os seus protagonistas - propositais imitações de heróis românticos -, criticando as suas atitudes, contrapostos às personagens femininas fortes, determinadas e insubmissas, que se desviam dos paradigmas das mocinhas romanescas. Além disso, ao não permitirem a identificação com o herói e inserirem comentários jocosos, Camilo e Macedo acabam por impedir a fruição da tensão dramática e o arrebatamento das emoções, próprios do romance sentimental, promovendo, em seu lugar, a reflexão distanciada sobre as convenções literárias e os comportamentos sociais.

Já Vinte Horas de Liteira e A Carteira de Meu Tio constituem narrativas de viagem nas quais não encontramos a descrição ufanista da paisagem nacional, nem as emocionantes aventuras típicas de tais relatos - trata-se de prosaicos deslocamentos por um Portugal e um Brasil repletos de mazelas sociais e políticas. Ao apresentarem um contundente olhar crítico sobre a sociedade oitocentista, os escritores se distanciam da tradição dos relatos de viagens como uma literatura amena e voltada ao entretenimento. Por outro lado, seus narradores também questionam o intuito didático encontrado no subgênero produzido no século XIX, não vendo a viagem como uma forma de aprendizagem, nem de aquisição de conhecimento por parte de seus personagens. Frustrando as expectativas do público, Camilo e Macedo apresentam narrativas de viagem centradas, no caso do primeiro, na crítica às 
convenções presentes nos mais diversos subgêneros do romance, e no caso do segundo, na crítica à corrupta política brasileira.

Para discutirmos o diálogo dos autores com a narrativa fantástica, selecionamos $O$ Esqueleto e alguns contos camilianos - Impressão Indelével, A Caveira e História de uma Porta-, e A Luneta Mágica, romance macediano. Em todos eles, as tópicas da literatura negra - tais como a virtude posta em prova pelas desgraças, o ambiente noturno e misterioso, o macabro e a crença no sobrenatural - são questionadas, ridicularizadas ou colocadas de maneira premeditadamente artificial pelos seus narradores, a fim de apenas aparentemente atenderem às expectativas de leitura do público que apreciava esse tipo de literatura. Com isso, os autores acabam por impedir a fruição do terror e do suspense através do riso e da crítica social, que relaxam a atenção do leitor e o chamam de volta à realidade, promovendo a sua conscientização, tanto para os problemas da sociedade, quanto para o caráter tolo das superstições populares e dos modelos literários que delas se aproveitam.

As análises de O Demônio do Ouro e de As Mulheres de Mantilha primaram por apontar os desvios que Camilo e Macedo fizeram dos moldes do romance histórico romântico, baseados na valorização da História nacional. Apesar de permearem as suas obras de pormenores históricos - por vezes postos com intuito paródico - e de inserirem trechos de aventura, típicos dos romances de capa e espada, os autores questionam o viés nacionalista, desvelando os problemas sociais da época: no escritor português, destaca-se a crítica ao sistema de apadrinhamento e dependência dos grandes proprietários; no brasileiro, o excesso de moralismo, que serve de justificativa à repressão das mulheres. Por outro lado, a figura do herói romântico, que deveria representar os valores da nação, é indefinida nas duas obras: Camilo apresenta um ladrão rocambolesco e um destemido aristocrata como importados e convencionais e um representante do povo português totalmente prosaico e incapaz de resolver as mazelas do país; já Macedo traz uma cortesã ciumenta como a responsável pela 
mudança política e uma personagem de sexualidade dúbia, que, ainda que protagonize a aventura no romance, não é capaz de provocar nenhuma transformação na realidade social. Tais personagens macedianas, que desafiam os códigos moralistas do século XIX, impeliramnos a refletir sobre a protagonista do romance camiliano As Três Irmãs, que também se distancia dos padrões de comportamento feminino da época, enfrentando o mercado de trabalho e recusando o casamento como única saída para as mulheres.

Por fim, buscamos mostrar o diálogo crítico de Camilo e Macedo com o discurso naturalista, baseado em teorias científicas - gestadas décadas antes das datas "oficiais" de "início" do realismo/naturalismo -, que tencionavam, através de conhecimentos da biologia e da medicina, explicar os comportamentos humanos e sociais. Em O Senhor Ministro, o narrador critica não somente o cientificismo da estética naturalista, como o caráter postiço do discurso romântico, denunciando a superficialidade de ambos e a ingenuidade do primeiro em sua intenção de regenerar Portugal através da literatura. O narrador de As Vítimas-Algozes, por sua vez, em sua defesa da abolição da escravatura, acaba indo na contramão das preconceituosas teorias científicas de cunho racial que justificavam a escravidão, vigentes no Brasil do século XIX, postulando que o que motiva as reações violentas dos escravos é a sua condição subumana de cativos, e não a sua raça. Assim, os narradores camiliano e macediano deslocam o foco da questão científica - biológica, médica, racial - para a questão social, mostrando uma visão mais lúcida e crítica das sociedades portuguesa e brasileira.

Dessa forma, a partir da análise que propusemos das obras selecionadas, é possível percebermos que Camilo e Macedo não aderiram plenamente às convenções romanescas em voga no Oitocentos, tendo-se em vista que exercitaram os mais variados subgêneros de forma muito particular. Se compreendermos a ironia romântica como "a reformulação do fazer literário e o questionar desse fazer” (FERRAZ, 1985, p. 39), podemos depreender que os autores dela fizeram uso, pois, como procuramos mostrar neste trabalho, os 
dois fizeram o questionamento dos pressupostos estéticos dos modelos vigentes. Jacinto do Prado Coelho, por exemplo, ressalta a "ironia emergente da ambiguidade das relações dialéticas entre vida e ficção, homem-autor e autor-inventor de histórias, vocação ou missão do escritor e negócio do livro" (2001, p. 427), procedimentos típicos da ironia romântica, como característicos da obra de Camilo. Lélia Parreira Duarte, por sua vez, defende que a ironia romântica aproximaria a ficção camiliana da machadiana, já que ambos "privilegiam a matreirice de emissores lúdicos que investem na comunicação" (2006, p. 142) e "multiplicam ironicamente emissor, receptor e mensagem, usam o dialogismo e dão extrema importância à figura do receptor" (2006, p. 142).

Todavia, esse conceito de ironia também pressupõe a coexistência de concepções opostas, tal como o esboçado pela teoria dos contrastes, sobre o grotesco e o sublime, no prefácio de Cromwell (1827), de Victor Hugo. Em seu postulado sobre o uso da ironia romântica na poesia, Friedrich Schlegel defende que essa deve ser uma síntese, uma "simetria de contradições, [...] eterno jogo alternado de entusiasmo e ironia" (1994, p. 55), estando “amparada [...] na harmonia do real e do ideal" - desde que este "realismo seja de ordem idealista e precise como que pairar sobre uma base e um solo ideais" (1994, p. 53). Em suma, nas palavras de Maria de Lourdes Ferraz, a ironia romântica se basearia, entre outras características, na "possibilidade de subdivisão do emissor" (1985, p. 25), tal como encontramos, por exemplo, na Lira dos Vinte Anos, de Álvares de Azevedo, "verdadeira medalha de duas faces" (Cf. AZEVEDO, 2000, p. 190), que oscila entre a defesa do sentimentalismo (na primeira parte) e a sua crítica (na segunda) ${ }^{3}$.

A nosso ver, no entanto, nos romances de Camilo e Macedo trabalhados aqui, não parece haver a "medalha de duas faces", a simetria, a coexistência do sentimentalismo

\footnotetext{
${ }^{3}$ Como nos referimos anteriormente, trata-se da "binomia" postulada pelo poeta, um "dualismo sistêmico" que gera "na obra uma oscilação entre um eu poético ingênuo e outro cínico" (CUNHA, Cilaine, 1998, p. 92).
} 
ingênuo e idealista, com a sua crítica irônica e realista ${ }^{4}$. Mesmo em obras como Amor de Perdição e A Moreninha, baseadas em histórias de amor, encontramos a jocosa voz do narrador, que a todo o momento ridiculariza a pieguice sentimental e os ideais românticos, impedindo a identificação do leitor com as vicissitudes dos personagens e a fruição da tensão dramática. Assim, o que é realçado nessas narrativas é, de fato, a crítica irônica e atenta à realidade social, plasmada na voz do narrador, que se sobressai e paira acima da história que conta. Por isso, supomos que talvez o mais indicado para definir a ficção camiliana e macediana não seja o conceito de ironia romântica, mas o de sátira menipeia ${ }^{5}$, que se destaca sobretudo pela "utilização sistemática da paródia [...] como meio de renovação artística" (REGO, 1989, p. 45) e pelo "aproveitamento sistemático do ponto de vista do kataskopos ou observador distanciado, que, como um espectador desapaixonado, analisa não só o mundo a que se refere como também a sua própria obra literária” (REGO, 1989, p. 45-46, grifo do autor).

De acordo com Enylton de Sá Rego, é possível apontarmos duas tradições de sátira que persistem até os dias de hoje: a da sátira romana (também chamada de moral), que “deve ter uma função moralizadora indubitável, e o riso deve servir apenas como um meio para as denúncias dos vícios da humanidade” (1989, p. 34), e a da sátira grega (também chamada de menipeia), que "não deve ser julgada pelos critérios moralistas impostos pela tradição da sátira romana" (1989, p. 36). Como discutimos em algumas de nossas análises, apesar de exercerem a crítica social, Camilo e Macedo não parecem acreditar na função regeneradora da literatura, chegando a contestar, por vezes, o próprio excesso de moralismo da hipócrita sociedade oitocentista. Nesse sentido, cremos que os autores, através do olhar

\footnotetext{
${ }^{4}$ O termo "realista" é aqui utilizado na mesma acepção de Schlegel, em contraponto ao termo "idealista", não estando relacionado à escola do realismo/naturalismo.

${ }^{5}$ Lembramos aqui que já procuramos estabelecer a filiação de Camilo à tradição da sátira menipeia em nossa Dissertação de Mestrado, anteriormente referida.
} 
distanciado e não moralizante de seus narradores, inserem-se na tradição da sátira menipeia, da qual também fazem parte, como defende Rego, Laurence Sterne e Machado de Assis.

É interessante verificarmos que a aproximação entre Macedo e Machado já foi notada, por exemplo, por Temístocles Linhares, que assinala a existência, em A Luneta Mágica - mas, acreditamos, não só nela - de "cenas curiosas que poderiam ser narradas por um Machado de Assis, o que faz até supor a hipótese da influência de Macedo sobre o autor de Dom Casmurro, que certamente o lera bastante, embora muita gente ainda possa achar desprimorosa para Machado tal leitura” (1987, p. 61). A inserção, por sua vez, do escritor português na tradição à qual pertencem Sterne e Machado foi apontada por Prado Coelho, que situa "Camilo na linha que vai de Sterne até Machado de Assis, donde certas reminiscências camilianas que nos acodem ao espírito quando lemos o genial autor das Memórias póstumas de Brás Cubas" (2001, p. 430). Da mesma forma, Paulo Franchetti defende a inclusão de Camilo numa "nova família", na qual "estará também, entre outros, Machado de Assis, com alguns graus de parentesco que ainda cumpre determinar" (2003, p. XXXII). Além disso, o crítico explica que

[...] Camilo nos aparecerá estilisticamente, num nível macroestrutural [...], muito próximo de escritores do século anterior, tal qual Sterne [...], que viam o texto romanesco não como sendo basicamente o desenvolvimento de uma intriga, nos moldes mais propriamente românticos, mas como uma prática narrativa em que o comentário filosófico ou simplesmente digressivo e espirituoso aparecia como um ponto distintivo do gosto. (2003, p. XXXIXXXII).

Contudo, Franchetti lembra que o escritor de Amor de Perdição (tal como Macedo) "não é um homem do século XVIII. Está submetido à prática da literatura como profissão e, portanto, condenado ao público que tem" (2003, p. XXXII). A sua "genialidade" - e também, a nosso ver, a de Macedo - estaria, nas palavras do pesquisador, “em utilizar criticamente as expectativas de leitura e as formas em que se cristalizam, sejam elas a novela 
sentimental [...] ou a narrativa naturalista” (2003, p. XXXII) - ou o romance histórico, a narrativa de viagem e a narrativa fantástica, em suma, os vários subgêneros em voga no século XIX, desvelando a inadequação, em Portugal e no Brasil, da aplicação dos pressupostos estéticos importados dos centros do capitalismo europeu.

Assim sendo, foi nosso intuito neste trabalho mostrar que, em vez de simplesmente aclimatarem em solo nacional os moldes romanescos estrangeiros, Camilo Castelo Branco e Joaquim Manuel de Macedo acabaram por deixar uma marca em seus romances que vai muito além da cor local - esta, aliás, também questionada por eles. Como procuramos mostrar em nossas análises, na ficção camiliana e macediana sobressai-se a relação dialógica com os modelos em voga e a subversão de seus pressupostos, mostrando uma visão muito mais crítica da sociedade do que a sua imagem cristalizada como autores comerciais, sentimentalistas e nacionalistas deixaria entrever - o que torna urgente a releitura desses escritores, que poderiam ser dignos de, sem grandes exageros, compartilhar com Machado o título de mestres nas periferias do capitalismo. 


\section{Bibliografia}

\subsection{Corpus literário}

\subsubsection{Obras de Camilo Castelo Branco}

CASTELO BRANCO, Camilo. Amor de Perdição: memórias de uma família. In:

Obras Completas. Porto: Lello \& Irmão, 1984. p. 373-547. v. 3.

A Brasileira de Prazins: cenas do Minho. In: Obras Completas. Porto: Lello \& Irmão, 1988. p. 675-857. v. 8.

Cancioneiro Alegre de Poetas Portugueses e Brasileiros. In: . Obras

Completas. Porto: Lello \& Irmão, 1989. p. 923-1412. v. 10.

A Caveira. In: Obras Completas. Porto: Lello \& Irmão, 1991. p. 391-411. v. 14 . Coração, Cabeça e Estômago. In: Obras Completas. Porto: Lello \& Irmão, 1984. p. 715-875. v. 3.

A Corja. In: Obras Completas. Porto: Lello \& Irmão, 1988. p. 561-674. v.

8.

O Demônio do Ouro: romance original. In: Obras Completas. Porto: Lello \& Irmão, 1987. p. 325-619. v. 7.

Dispersos de Camilo. Coimbra: Imprensa da Universidade, 1924. v. 1: crônicas (1848-1852). Compilação e notas de Júlio Dias da Costa.

Dispersos de Camilo. Coimbra: Imprensa da Universidade, 1925. v. 2: crônicas (1853-1856). Compilação e notas de Júlio Dias da Costa. 
Dispersos de Camilo. Coimbra: Imprensa da Universidade, 1926. v. 3: crônicas (1857-1885). Compilação e notas de Júlio Dias da Costa.

Dispersos de Camilo. Coimbra: Imprensa da Universidade, 1928. v. 4: artigos (1846-1889). Compilação e notas de Júlio Dias da Costa.

O Esqueleto: romance. In:

. Obras Completas. Porto: Lello \& Irmão, 1985. p. $1163-1358$. v. 4.

Eusébio Macário. In: Obras Completas. Porto: Lello \& Irmão, 1988. p. 455-559. v. 8.

História de uma Porta. In: . Obras Completas. Porto: Lello \& Irmão, 1991. p. 1017-1027. v. 13.

Impressão Indelével (1842). In: Obras Completas. Porto: Lello \& Irmão, 1990. p. 291-300. v. 11.

Noites de Insônia: oferecidas a quem não pode dormir. In: Obras Completas. Porto: Lello \& Irmão, 1991. p. 667-1445. v. 14.

A Queda dum Anjo. In: Obras Completas. Porto: Lello \& Irmão, 1986. p. 833-1025. v. 5.

O Que Fazem Mulheres: romance filosófico. In: Obras Completas. Porto: Lello \& Irmão, 1983. p. 1227-1372. v. 2.

O Senhor Ministro. In: Obras Completas. Porto: Lello \& Irmão, 1993. p. 619-691. v. 15.

As Três Irmãs. In: Obras Completas. Porto: Lello \& Irmão, 1984. p. 185373. v. 3 .

Vinte Horas de Liteira: romance original. In: Lello \& Irmão, 1985. p. 987-1161. v. 4. Obras Completas. Porto: 


\subsubsection{Obras de Joaquim Manuel de Macedo}

MACEDO, Joaquim Manuel de. A Carteira de Meu Tio. Belo Horizonte; Rio de Janeiro: Livraria Garnier, 2001.

A Luneta Mágica. 4. ed. São Paulo: Ática, 1977.

Memórias do Sobrinho de Meu Tio. São Paulo: Companhia das Letras, 1995.

A Moreninha. 25. ed. São Paulo: Ática, 1994.

1965.

As Mulheres de Mantilha: romance histórico. 3. ed. São Paulo: Melhoramentos,

As Vítimas-Algozes: quadros da escravidão. 3. ed. São Paulo: Scipione, 1991. 


\subsubsection{Obras de outros autores}

ALENCAR, José de. Ao Correr da Pena. São Paulo: Martins Fontes, 2004.

O Guarani. 30. ed. Rio Janeiro: Ediouro, 2000.

ASSIS, Machado de. Memórias Póstumas de Brás Cubas. Rio de Janeiro; Belo Horizonte: Livraria Garnier, 1994.

AZEVEDO, Manuel Antônio Álvares de. Obra Completa. Rio de Janeiro: Nova Aguilar, 2000 .

BOTELHO, Abel. Patologia Social: O Barão de Lavos. Porto: Livraria Lello, 1993. v. 1.

Patologia Social: O Livro de Alda. 2. ed. Porto: Livraria Chardron, [19--]. v. 2.

BRONTË, Charlotte. Jane Eyre. London: Penguin Books, 1994.

DUMAS FILHO, Alexandre. La Dame aux Camélias. Paris: Calmann-Levy, 1961.

GARRETT, Almeida. Viagens na Minha Terra. Porto: Porto Editora, 1982.

GOETHE, Johann Wolfgang von. Fausto. Tradução de Jenny Klabin Segall. São Paulo: Editora 34, 2011.

HERCULANO, Alexandre. Lendas e narrativas. In: As Melhores Obras de Alexandre Herculano. S/l: Círculo de Leitores, 1986. p. 191. v. 7; tomo 2.

Opúsculos. Lisboa: Antiga Casa Bertrand José Bastos \& Cia., 1907. Tomo 9: literatura 1.

HUGO, Victor. Do Grotesco e do Sublime: tradução do prefácio de Cromwell. Tradução de Célia Berrettini. 2. ed. São Paulo: Perspectiva, 2004. 
Notre-Dame de Paris. Paris: Gallimard, 1995.

QUEIRÓS, Eça de. O Crime do Padre Amaro. São Paulo: Moderna, 1994.

QUENTAL, Antero de. Odes Modernas. Lisboa: Couto Martins: 1952.

STERNE, Laurence. The Life and Opinions of Tristram Shandy, Gentleman. London: Penguin Books, 2003. 


\subsection{Bibliografia crítica}

\subsubsection{Bibliografia crítica sobre Camilo Castelo Branco}

ADERALDO, Ana Carolina de Andrade. O narrador/autor em Duas Horas de Leitura: uma abordagem da ironia retórica no discurso camiliano. In: DUARTE, Lélia Parreira (Org.). Ironia e Humor na Obra de Camilo Castelo Branco: Cadernos CESPUC de Pesquisa, Belo Horizonte, n. 7, p. 13-21, maio 2001.

ALVES, José Édil de Lima. A Paródia em Novelas-Folhetins Camilianas. Lisboa: Instituto de Cultura e Língua Portuguesa; Ministério da Educação e Cultura, 1990.

BAPTISTA, Abel Barros. Camilo e a Revolução Camiliana. Lisboa: Quetzal, 1988.

BAPTISTA, Abel Barros (Org.). Amor de Perdição: uma revisão. Coimbra: Angelus Novus, 2009.

BAPTISTA, Abel Barros et al (Orgs.). Camilo - Evocações e Juízos: antologia de ensaios. Porto: Comissão Nacional das Comemorações Camilianas, 1991.

BARCELLOS, José Carlos. Masculinidade e modernidade em Camilo Castelo Branco. In: SOUSA, Sérgio Guimarães de; MARTINS, José Cândido de Oliveira (Orgs.). Leituras do Desejo em Camilo Castelo Branco. Guimarães: Opera Omnia, 2010. p. 97-114.

BELO, Rosário Luppi. “Amar até doer": o desejo do amor e a perdição dos desejos. In: SOUSA, Sérgio Guimarães de; MARTINS, José Cândido de Oliveira (Orgs.). Leituras do Desejo em Camilo Castelo Branco. Guimarães: Opera Omnia, 2010. p. 131-155.

BERARDINELLI, Cleonice. Garrett e Camilo: românticos heterodoxos?. Bulletin des Études Portugaises et Brésiliennes, Lisbonne, tomes 37-38, p. 61-81, 1977-1978. Nouvelle série.

Pela mão do narrador. In: CONGRESSO INTERNACIONAL DE ESTUDOS CAMILIANOS, 1991, Coimbra. Actas... Coimbra: Comissão Nacional das Comemorações Camilianas, 1994. p. 223-236. 
BESSA-LUÍS, Agustina. Riso e castigo em Camilo Castelo Branco. Estudos Camilianos: Camilo Castelo Branco - Jornalismo e Literatura no Século XIX, Braga, n. 3, p. 125-130, 1993.

O romanesco em Camilo: “A Enjeitada”. Revista Colóquio/Letras, Lisboa, n. 54, p. 5-13, mar. 1980.

BRAGA, João Paulo. Verdade, ficção e metaficção em Camilo: a história da "História de uma Porta”. Revista Portuguesa de Humanidades, Braga, v. 9, n. 1/2, p. 267-280, 2005.

BRAGA, Teófilo. Camilo Castelo Branco. In: As Modernas Ideias na Literatura Portuguesa. Porto: Lugan \& Genelioux, 1892. p. 240-285. v. 1.

BRANCO, Paula Isabel Castelo. Espaço ou espaços do Brasil na novela camiliana. Vária Escrita, Sintra, n. 6, p. 45-59, 1999.

CABRAL, Alexandre. Dicionário de Camilo Castelo Branco. 2. ed. Lisboa: Caminho, 1988. Investigação sobre a identidade dos protagonistas de uma ficção camiliana: "O Esqueleto”. Bibliotheca Portucalensis, Porto, n. 5, p. 103-122, 1990. 2. série.

Polêmicas de Camilo Castelo Branco. Lisboa: Livros Horizonte, 1982. v. 8.

Horizonte, 1985.

Subsídio para uma Interpretação da Novelística Camiliana. Lisboa: Livros

CABRAL, António. A técnica da distanciação em Camilo. Estudos Camilianos: Camilo Castelo Branco - Jornalismo e Literatura no Século XIX, Braga, n. 3, p. 51-60, 1993.

CAMPOS, Maria Clara Lourenço de. A pulsão de morte nas heroínas de Amor de Perdição. In: A MULHER NA VIDA E OBRA DE CAMILO, 1995, Vila Nova de Famalicão. Actas... Braga: Centro de Estudos Camilianos, 1997. p. 149-156.

CARVALHO, João Soares. Camilo Castelo Branco. In: MACHADO, Álvaro Manuel et al. História da Literatura Portuguesa. Mem Martins: Publicações Alfa, 2003. p. 343-394. v. 4.

CASTELO-BRANCO, Fernando. A conjuntura pessoal, política e sociológica do romance histórico de Camilo. In: ESTÉTICA DO ROMANTISMO EM PORTUGAL, 1., 1970, 
Lisboa. Estética... Lisboa: Centro de Estudos do Século XIX do Grêmio Literário, 1974. p. 153-161.

CASTRO, Aníbal Pinto de. Da realidade à ficção na novela camiliana. Tellus: revista de cultura, Vila Real, n. 17, p. 3-20, 1987.

Para uma teoria camiliana da ficção narrativa. Arquivos do Centro Cultural Português, Lisboa; Paris, v. 29, p. 53-70, 1991.

Prefácio. In: CASTELO BRANCO, Camilo. Amor de Perdição. Porto: Caixotim, 2006. p. 9-75.

Processos de construção da narrativa camiliana. In: CONGRESSO INTERNACIONAL DE ESTUDOS CAMILIANOS, 1991, Coimbra. Actas... Coimbra: Comissão Nacional das Comemorações Camilianas, 1994. p. 59-74.

A teoria camiliana da novela. Bibliotheca Portucalensis, Porto, n. 5, p. 13-31, 1990. 2. série.

CHAVES, Castelo Branco. Nota preliminar. In: CASTELO BRANCO, Camilo. O Esqueleto. 10. ed. Lisboa: Parceria A. M. Pereira, 1969. p. 5-17.

Nota preliminar. In: CASTELO BRANCO, Camilo. O Senhor do Paço de Ninães.

8. ed. Lisboa: Parceria A. M. Pereira, 1966. p. 5-19.

CHORÃO, João Bigotte. Camilo Camiliano. Lisboa: Rei dos Livros, 1993a.

Camilo e a tradição narrativa camiliana. Boletim da Casa de Camilo, São Miguel de Ceide, n. 3, p. 109-119, ago. 1984. 3. série. abr. $1993 b$.

Camilo em terra queirosiana. Tellus: revista de cultura, Vila Real, n. 20, p. 49-61, Um ministro malogrado. In: CASTELO BRANCO, Camilo. O Senhor Ministro. Lisboa: Vega, [1989]. p. 7-14.

Páginas Camilianas e Outros Temas Oitocentistas. Lisboa: Guimarães, 1990. 
COELHO, Jacinto do Prado. O "Amor de Perdição", romance do pundonor?. In: A

Letra e o Leitor. 2. ed. Braga: Moraes, 1977. p. 103-106.

Introdução ao Estudo da Novela Camiliana. 3. ed. Lisboa: Imprensa Nacional;

Casa da Moeda, 2001.

CORREIA, Hélia. Introdução. In: CASTELO BRANCO, Camilo. Vinte Horas de Liteira. Lisboa: Ulmeiro, 1984. p. 5-23.

CORREIA, João de Araújo. Nota preliminar. In: CASTELO BRANCO, Camilo. Cenas Contemporâneas. 6. ed. Lisboa: Parceria A. M. Pereira, 1970. p. II-XVII.

COSTA, João (Org.). Castilho e Camilo: correspondência trocada entre os dois escritores. Coimbra: Imprensa da Universidade, 1924.

COSTA, Othon. Camilo Castelo Branco e o Brasil. Rio de Janeiro: Continental, 1956.

COURTEAU, Joanna. O discurso sobre o discurso em Amor de Perdição. In: CAMILO CASTELO BRANCO INTERNATIONAL COLLOQUIUM, 1991, Santa Barbara. Proceedings... Santa Barbara: Center for Portuguese Studies; University of California, 1995. p. 241-248.

DUARTE, Lélia Parreira. A ironia na obra de Camilo Castelo Branco. In: DUARTE, Lélia Parreira (Org.). Ironia e Humor na Obra de Camilo Castelo Branco: Cadernos CESPUC de Pesquisa, Belo Horizonte, n. 7, p. 5-12, maio 2001.

FERRAZ, Maria de Lourdes A. Camilo e o romantismo: a retórica do sentimento. In: CONGRESSO INTERNACIONAL DE ESTUDOS CAMILIANOS, 1991, Coimbra. Actas... Coimbra: Comissão Nacional das Comemorações Camilianas, 1994. p. 237-251.

Castelo Branco, Camilo (Ferreira Botelho). In: BUESCU, Helena Carvalhão (Coord.). Dicionário do Romantismo Literário Português. Lisboa: Caminho, 1997. p. 8086.

. O realismo romântico de Camilo. Arquivos do Centro Cultural Português, Lisboa; Paris, v. 29, p. 71-84, 1991.

FERRAZ, Maria de Lourdes A. (Coord.). Dicionário de Personagens da Novela Camiliana. Lisboa: Caminho, 2002. 
FRANÇA, José-Augusto. Camilo ou a opção da desventura. In: O Romantismo em

Portugal: estudos de fatos socioculturais. Lisboa: Livros Horizonte, 1993. p. 281-305. v. 3 : os anos da razão.

FRANCHETTI, Paulo. Apresentação. In: CASTELO BRANCO, Camilo. Coração, Cabeça e Estômago. São Paulo: Martins Fontes, 2003. p. IX-LXII.

A novela camiliana. In: Estudos de Literatura Brasileira e Portuguesa.

Cotia: Ateliê, 2007.

GARCEZ, Maria Helena Nery. Acerca das designações dos agentes em "Amor de Perdição". In: CONGRESSO INTERNACIONAL DE ESTUDOS CAMILIANOS, 1991, Coimbra. Actas... Coimbra: Comissão Nacional das Comemorações Camilianas, 1994. p. 471-482.

GERALDES, Fernanda da Costa. As Classes Sociais do Século XIX na Novela Camiliana. [1966?]. Dissertação (Licenciatura em Filologia Românica) - Faculdade de Letras, Universidade de Lisboa, Lisboa, 1966.

GRANJA, Rosemary da Silva. Brasileiros e Portugueses - Todos Fora do Lugar: a imagem do brasileiro torna-viagem na ficção camiliana. 2009. Tese (Doutorado em Estudos Comparados de Literaturas de Língua Portuguesa) - Faculdade de Filosofia, Letras e Ciências Humanas, Universidade de São Paulo, São Paulo, 2009. Disponível em: <http://www.teses.usp.br/teses/disponiveis/8/8156/tde-01022010-173537/pt-br.php>. Acesso em: 1 mar. 2012.

JESUS, Maria Saraiva de. Eusébio Macário e A Corja: entre a paródia satírica e o riso carnavalesco. Tellus: revista de cultura, Vila Real, n. 20, p. 69-84, abr. 1993.

Mecanismos e efeitos do riso na obra de Camilo Castelo Branco. Revista da Universidade de Aveiro: Letras, Aveiro, n. 17, p. 57-104, 2000.

LAWTON, R. A. Technique et signification de Amor de Perdição. Bulletin des Études Portugaises, Paris; Lisboa, tome 25, p. 77-135, 1964. Nouvelle série.

LEMOS, Esther de. Da casa à cela. In: BAPTISTA, Abel Barros et al (Orgs.). Camilo Interpretações Modernas: antologia. Porto: Comissão Nacional das Comemorações Camilianas, 1992. p. 23-27.

Introdução. In: CASTELO BRANCO, Camilo. Amor de Perdição: memórias duma família. 10. ed. Lisboa: Ulisseia, 2003. p. 34-55. 
Nota preliminar. In: CASTELO BRANCO, Camilo. Vinte Horas de Liteira. 5. ed. Lisboa: Parceria A. M. Pereira, 1966. p. 5-39.

LIMA, Isabel Pires de. Ainda o fantasma do naturalismo em Camilo ( $O$ Sr. Ministro). In: CONGRESSO INTERNACIONAL CAMILO CASTELO BRANCO E O OITOCENTOS: 150 anos do Amor de Perdição, 2012, São Paulo. Conferência.

Camilo e o fantasma do naturalismo: "Eusébio Macário" e "A Corja". Línguas e Literaturas: revista da Faculdade de Letras do Porto, Porto, v. 9, p. 119-138, 1992. 2. série. Disponível em: <http://ler.letras.up.pt/uploads/ficheiros/2644.pdf>. Acesso em: 25 fev. 2010.

. Camilo e o naturalismo: "pastiche" ou paródia?. In: CAMILO CASTELO BRANCO INTERNATIONAL COLLOQUIUM, 1991, Santa Barbara. Proceedings... Santa Barbara: Center for Portuguese Studies; University of California, 1995. p. 97-107.

LOPES, Óscar. Claro-escuro camiliano. In:

A Busca de Sentido: questões de literatura portuguesa. Lisboa: Caminho, 1994a. p. 39-65.

Ensaios Camilianos. Porto: Fundação Eng. António de Almeida, 2007.

Formas de recepção a Camilo. In: CONGRESSO INTERNACIONAL DE ESTUDOS CAMILIANOS, 1991, Coimbra. Actas... Coimbra: Comissão Nacional das Comemorações Camilianas, 1994b. p. 19-34.

LOURENÇO, Eduardo. Situação de Camilo. In: O Canto do Signo. Lisboa: Presença, 1994. p. 219-226.

O tempo de Camilo ou a ficção no país das lágrimas. In: As Saias de Elvira

e Outros Ensaios. Lisboa: Gradiva, 2006. p. 59-72.

MACHADO, Álvaro Manuel. Camilo e a crítica ao romantismo: modelos nacionais e estrangeiros. In: Presença, 1996. p. 30-37. Do Romantismo aos Romantismos em Portugal. Lisboa: . Camilo, o "francesismo" e a "escola do folhetim". Vária Escrita, Sintra, n. 6, p. 195-201, 1999.

MARINHO, Maria de Fátima. Camilo Castelo Branco e a atração do horrível. In: ENCONTRO DE ESTUdOS ROMÂNTICOS, 1., [200-], Porto. Actas... Porto: Faculdade de 
Letras da Universidade do Porto, 2002. p. 27-35. Disponível em: <http://ler.letras.up.pt/uploads/ficheiros/5478.pdf>. Acesso em: 19 set. 2009.

. Camilo Castelo Branco e o fascínio do romance histórico. Vária Escrita, Sintra, n. 6, p. 177-193, 1999.

MARQUES, Henrique. Os Editores de Camilo: alguns subsídios para a história da livraria em Portugal. Lisboa: Empresa da História de Portugal, 1925.

MARTINS, José Cândido. Afirmação da estética realista-naturalista e a recepção críticoparodística de Camilo. BIENAL DE FAMALICÃO, 2, [199-], Vila Nova de Famalicão. Em Torno de Camilo. Vila Nova de Famalicão: Fundação Cupertino de Miranda; Casa-Museu de Camilo; Biblioteca Municipal Camilo Castelo Branco; Casa da Cultura de Famalicão, 1997. p. 18-58.

Prefácio. In: CASTELO BRANCO, Camilo. Eusébio Macário/A Corja. Porto: Caixotim, 2003. p. 7-47.

MCNAB, Gregory. Camilo e a problematização do romance histórico. Luso-Brazilian Review, Madison, n. 30/1, p. 167-173, 1993.

O romance histórico de Camilo: expectativas frustradas?. In: CAMILO CASTELO BRANCO INTERNATIONAL COLLOQUIUM, 1991, Santa Barbara. Proceedings... Santa Barbara: Center for Portuguese Studies; University of California, 1995. p. 168-179.

MENDES, Maria do Carmo Pinheiro e Silva Cardoso. Os Don Juans de Camilo Castelo Branco. Diacrítica: ciências da literatura, Braga, n. 22/3, p. 359-390, 2008.

MINDLIN, Dulce M. Viana. Paixão: doença ou fado?. In: CAMILO CASTELO BRANCO INTERNATIONAL COLLOQUIUM, 1991, Santa Barbara. Proceedings... Santa Barbara: Center for Portuguese Studies; University of California, 1995. p. 84-96.

MONGUELLI, Lênia Márcia. Ironia e Ambiguidade: o herói camiliano. São Paulo: Universidade de São Paulo, 1993.

MONTEIRO, Maria da Assunção Morais. Dialogismo e Narrativa em Vinte Horas de Liteira. Vila Real: Universidade de Trás-os-Montes e Alto Douro, 1998. 
Romantismo e Realismo no Amor de Perdição. 2. ed. Vila Real: Universidade de Trás-os-Montes e Alto Douro, 1996.

MOUTINHO, José Viale. Prefácio: notas sobre ossadas camilianas. In: CASTELO BRANCO, Camilo. O Esqueleto. Lisboa: Rolim, 1985. p. 7-19.

MOUTINHO, José Viale (Org.). Poses Para um Retrato de Época: Camilo Castelo Branco visto pelos seus contemporâneos. Vila Nova de Famalicão: Quasi Edições; Biblioteca Oito Séculos, 2005.

NÉVES, Alvaro (Org.). Camilo Castelo Branco: notas à margem em vários livros da sua biblioteca. Lisboa: Parceria António Maria Pereira, 1916.

OLIVEIRA, Paulo Motta. Aspectos do amor em Camilo: da heroína romântica à mulher comum. Letras, Curitiba, n. 47, p. 83-94, 1997.

Camilo e o Brasil. In: SANTOS, Gilda (Org.). Amor Sem Perdição: Camilo e o Real Gabinete Português de Leitura. Rio de Janeiro: Real Gabinete Português de Leitura, 2012. p. 5-7.

. Da ficção camiliana como interpretação de Portugal. In: ENCONTRO BRASILEIRO DE PROFESSORES DE LITERATURA PORTUGUESA, 19., 2003, Curitiba. Anais... Curitiba: ABRAPLIP, 2003. p. 849-854. 1 CD-ROM.

. Nótulas acerca do Brasil em dois romances camilianos. Estudos Portugueses e Africanos, Campinas, n. 33/34, p. 99-111, jan./dez. 1999.

. Riso e melancolia: figurações do amor em um mundo desencantado. In: SEMINÁRIO DE LITERATURAS DE LÍNGUA PORTUGUESA: PORTUGAL E ÁFRICA, 3., 2002, Niterói. Anais... Rio de Janeiro: Léo Christiano Editorial, 2004.

ORTIGÃO, Ramalho. Figuras e Questões Literárias. 2. ed. Lisboa: Livraria Clássica, 1945. Tomo 1: literatura de hoje - Luís de Camões, Garrett, Camilo Castelo Branco.

PAVANELO, Luciene Marie. Camilo Castelo Branco: iluminado e romântico?. In: COLÓQUIO DO PPRLB: ENTRE ILUMINADOS E ROMÂNTICOS, 3., 2006, Rio de Janeiro. Atas... Rio de Janeiro: Real Gabinete Português de Leitura, 2006. Disponível em: <http://www.realgabinete.com.br/geadmedia/mediapackages/giadrgpl_rgpl/documentsmain/2 01110181154952dde_lucienemariepavaoriginal.pdf>. Acesso em: 4 jul. 2012. 
Camilo e a paródia do ultrarromantismo: o (anti-)herói romântico. In: MUNIZ, Márcio; SEIDEL, Roberto (Orgs.). Novos Nortes Para a Literatura Portuguesa. Feira de Santana: Programa de Pós-Graduação em Literatura e Diversidade Cultural; UEFS, 2007. p. 293-299.

Entre o Coração e o Estômago: o olhar distanciado de Camilo Castelo Branco. 2008. Dissertação (Mestrado em Literatura Portuguesa) - Faculdade de Filosofia, Letras e Ciências Humanas, Universidade de São Paulo, São Paulo, 2009. Disponível em: <http://www.teses.usp.br/teses/disponiveis/8/8150/tde-25082009-151642/pt-br.php>. Acesso em: 30 nov. 2009.

O narrador camiliano e o seu olhar distanciado entre o coração e o estômago. In: ALVES, Carla Carvalho et al. (Orgs.). Repensando a Literatura Portuguesa Oitocentista: ensaios críticos. São Paulo: Biblioteca 24X7, 2010. p. 67-92.

O olhar camiliano sobre o contexto literário oitocentista: metalinguagem e paródia em $O$ Que Fazem Mulheres. Revista Desassossego, São Paulo, n. 1, 2009. Disponível em: $<$ http://www.revistas.usp.br/desassossego/article/view/47627/51367>. Acesso em: 8 fev. 2010 .

O olhar distanciado de Camilo e a quebra da catarse. Remate de Males, Campinas, v. 28 , n. 2, p. 267-277, 2008. Disponível em: <http://www.iel.unicamp.br/ojs234/index.php/remate/article/view/856/623>. Acesso em: 10 fev. 2011.

O que fazem as mulheres: as personagens femininas de Camilo Castelo Branco. Antares: Letras e Humanidades, Caxias do Sul, v. 3, n.6, p. 144-160, 2011. Disponível em: <http://www.ucs.br/etc/revistas/index.php/antares/article/view/935/947>. Acesso em: 22 out. 2012.

A realidade camiliana frente à fantasia ultrarromântica: visões dissonantes entre Camilo Castelo Branco, Soares de Passos e Álvares de Azevedo. In: ENCONTRO PAULISTA DE PROFESSORES DE LITERATURA PORTUGUESA, 1., 2005, São Paulo. Anais... São Paulo: Universidade de São Paulo, 2008. Disponível em:

<http://www.fflch.usp.br/dlcv/lpp/I_EPPLP.pdf>. Acesso em: 3 abr. 2009.

PICCHIO, Luciana Stegagno. Amor de Perdição: uma "crônica stendhaliana" - estudo de fortuna. In: CONGRESSO INTERNACIONAL DE ESTUDOS CAMILIANOS, 1991, Coimbra. Actas... Coimbra: Comissão Nacional das Comemorações Camilianas, 1994. p. 765-775.

PIMENTEL, Alberto. Camilo Castelo Branco. In: Homens e Datas. Porto: Lello \& Irmão, 1981. p. 37-44. 
QUADROS, António. Nota preliminar: Camilo, escritor profundo. In: CASTELO BRANCO, Camilo. As Três Irmãs: romance. Lisboa: Parceria A. M. Pereira, 1974. p. I-XXIV.

RÉGIO, José. Camilo, romancista português. In: Ensaios de Interpretação Crítica:

Camões, Camilo, Florbela, Sá-Carneiro. Póvoa de Varzim: Brasília, 1980. p. 71-165.

. Nota preliminar. In: CASTELO BRANCO, Camilo. O Demônio do Ouro: romance original. 6. ed. Lisboa: Parceria A. M. Pereira, 1970. p. I-XII.

RÊGO, Costa (Org.). Camilo Castelo Branco: Polêmicas em Portugal e no Brasil. Rio de Janeiro: Dois Mundos, 1944.

REIS, Carlos. Camilo Castelo Branco e a evolução do Romantismo português. In:

Literatura Portuguesa Moderna e Contemporânea. Lisboa: Universidade Aberta, [1990].

- Camilo e a poética do romance. In: CAMILO CASTELO BRANCO INTERNATIONAL COLLOQUIUM, 1991, Santa Barbara. Proceedings... Santa Barbara: Center for Portuguese Studies; University of California, 1995. p. 63-74.

Narrativa e metanarrativa: Camilo e a poética do romance. In: CONGRESSO INTERNACIONAL DE ESTUDOS CAMILIANOS, 1991, Coimbra. Actas... Coimbra: Comissão Nacional das Comemorações Camilianas, 1994. p. 105-118.

REIS, Carlos; PIRES, Maria da Natividade. Camilo Castelo Branco e o romantismo português. In: REIS, Carlos (Dir.). História Crítica da Literatura Portuguesa. 2. ed. Lisboa: Verbo, [1993]. p. 185-203. v. 5: o romantismo.

REMÉDIOS, Maria Luíza Ritzel. Amor de Perdição: estrutura e plurilinguismo. In: CONGRESSO INTERNACIONAL DE ESTUDOS CAMILIANOS, 1991, Coimbra. Actas... Coimbra: Comissão Nacional das Comemorações Camilianas, 1994. p. 795-804.

RIBEIRO, Aquilino. Camões, Camilo, Eça e Alguns Mais: ensaios de crítica históricoliterária. 4. ed. Lisboa: Livraria Bertrand, [1949?].

RIBEIRO, João. Camilo e a literatura brasileira. Revista da Academia Brasileira de Letras, Rio de Janeiro, v. 18, n. 41, p. 422-426, maio 1925. 
RIBEIRO, Maria Aparecida. Camilo e Júlio Dinis: adesões por acaso. In: REIS, Carlos (Dir.). História Crítica da Literatura Portuguesa. 2. ed. Lisboa: Verbo, [1993]. p. 141-149. v. 6: realismo e naturalismo.

RIBEIRO, Raquel de Sousa. O espaço na novela Amor de Perdição, de Camilo Castelo Branco. In: CONGRESSO INTERNACIONAL DE ESTUDOS CAMILIANOS, 1991, Coimbra. Actas... Coimbra: Comissão Nacional das Comemorações Camilianas, 1994. p. 629-657.

RITA, Annabela. O amor $e$ de perdição.... Boletim da Casa de Camilo, São Miguel de Ceide, n. 8, p. 7-13, dez. 1986. 3. série.

Camilo: reflexos, ambiguidade. Vária Escrita, Sintra, n. 6, p. 37-43, 1999.

Prefácio. In: CASTELO BRANCO, Camilo. Vinte Horas de Liteira. Porto: Edições Caixotim, 2002. p. XI-XXXI.

Vinte Horas de Liteira: estratégia e retórica românticas. Boletim da Casa de Camilo, São Miguel de Ceide, n. 11/12, p. 27-36, dez. 1988. 3. série.

ROCHA JÚNIOR. Um paradoxo: do realismo de Camilo ao romantismo de Eça de Queirós. Camiliana \& Vária: Revista-Enciclopédica do Círculo Camiliano, Lisboa, n. 2, p. 79-82, abr./jun. 1951.

ROCHETA, Maria Isabel. Introdução. In: CASTELO BRANCO, Camilo. Amor de Perdição. Lisboa: Editorial Comunicação, 1983. p. 17-71.

RODRIGUES, Ernesto. Introdução. In: CASTELO BRANCO, Camilo. A Corja: sentimentalismo. [S.1.]: Ulisseia, 2000. p. 7-30. 1991. p. 7-32.

Introdução. In: CASTELO BRANCO, Camilo. Eusébio Macário. [S.l.]: Ulisseia, Duas Horas de Leitura. 8. ed. Lisboa: Parceria A. M. Pereira, 1967. p. 5-43.

RODRIGUES, Urbano Tavares. Luzes e sombras do narrador em "Vinte Horas de Liteira". In: COLÓQUIO DE ESTUdOS CAMILIANOS, [199-], Lisboa. Publicações... Lisboa: Academia das Ciências de Lisboa, 1993. p. 79-84. 
ROSADO, Teresa Manuela Vasques Fadista da Cruz. Camilo e Eça: o apelo do horror. [2004?]. Dissertação (Mestrado em Estudos Românicos) - Faculdade de Letras, Universidade de Lisboa, Lisboa, 2004.

SAlGADO, Benjamim. Camilo em Datas, Fatos e Comentários. Vila Nova de Famalicão: Fundação Cupertino de Miranda, 1972.

SANTOS, Elizabeth. Camilo Castelo Branco: uma concepção irônica de mundo. In: DUARTE, Lélia Parreira (Org.). Ironia e Humor na Obra de Camilo Castelo Branco: Cadernos CESPUC de Pesquisa, Belo Horizonte, n. 7, p. 50-63, maio 2001.

SANTOS, Gilda. Amor de Perdição e outras artes: breve esboço. In: SANTOS, Gilda (Org.). Amor Sem Perdição: Camilo e o Real Gabinete Português de Leitura. Rio de Janeiro: Real Gabinete Português de Leitura, 2012. p. 37-39.

SANTOS, João Camilo dos. Aquilo a que se chama amor: as histórias por detrás das histórias que conta Camilo. Colóquio/Letras, Lisboa, n. 119, p. 60-75, jan./mar. 1991.

SANTOS, Maria Eduarda Borges dos. Do Diálogo ao Dialogismo na Obra de Camilo Castelo Branco. Braga: Centro de Estudos Camilianos, 1999.

Polifonia camiliana. Boletim da Casa de Camilo, São Miguel de Ceide, n. 11/12, p. 7-26, dez. 1988. 3. série.

SARAIVA, António José; LOPES, Óscar. Camilo Castelo Branco. In: História da Literatura Portuguesa. 17. ed. Porto: Porto Editora, 1996. p. 777-795.

SEGORBE, Isabel. Prefácio. In: CASTELO BRANCO, Camilo. O Sr. Ministro. Coimbra: Quarteto, 2000. p. 5-12.

SEIXO, Maria Alzira. Modelos passionais na narrativa camiliana. In: CAMILO CASTELO BRANCO INTERNATIONAL COLLOQUIUM, 1991, Santa Barbara. Proceedings... Santa Barbara: Center for Portuguese Studies; University of California, 1995. p. 75-83

SEQUEIRA, Rosa Maria. "Amor de Perdição": contribuições para o estudo do narrador. Lusorama, [S.1.], n. 6, p. 22-27, nov. 1987.

SÉRGIO, António. Sobre o Amor de Perdição. In: Ensaios. Lisboa: Livraria Sá da Costa, 1974. p. 94-99. Tomo 7. 
SIMÕES, João Gaspar. Camilo Castelo Branco. In:

Português. Lisboa: Estúdios Cor, 1969. p. 121-142. v. 2.

\section{História do Romance}

SOUSA, Sérgio Guimarães de. Crimes de amor? Tradição crítica de Amor de Perdição. Diacrítica, Braga, n. 21-3, p. 417-436, 2007.

Posfácio. In: CASTELO BRANCO, Camilo. História de uma Porta. Rio de Janeiro: 7Letras, 2009. p. 36-58.

VALENTE, Vasco Pulido. "Prefácio". In: CASTELO BRANCO, Camilo. Amor de Perdição: memórias de uma família. Lisboa: Alétheia, 2005, p. 5-20.

\subsubsection{Filme cinematográfico sobre a obra de Camilo}

UM AMOR DE PERDIÇÃO. Direção: Mário Barroso. Produção: Paulo Branco. Intérpretes: Tomás Alves; Patrícia Franco; Willion Brandão; Catarina Wallenstein; Ana Padrão; Rui Morison; Virgílio Castelo; Rafael Morais; Ana Moreira e outros. Roteiro: Carlos Saboga. Portugal: Clap Filmes; Plateau Produções; Leopardo Filmes, 2008. 81 min, color. 


\subsubsection{Bibliografia crítica sobre Joaquim Manuel de Macedo}

ALMEIDA, Leandro Thomaz de. Introdução: a pena afiada de Joaquim Manuel de Macedo. In: MACEDO, Joaquim Manuel de. A Carteira de Meu Tio. São Paulo: Hedra, 2010a, p. 926.

Trajetórias da Recepção Crítica de Joaquim Manuel de Macedo. 2008. Dissertação (Mestrado em Teoria e História Literária) - Instituto de Estudos da Linguagem, Universidade Estadual de Campinas, Campinas, 2008. Disponível em: <http://www.bibliotecadigital.unicamp.br/>. Acesso em: 3 out. 2011.

ALVES, Marcos Francisco. História e Literatura em diálogo: representações da escravidão em Bernardo Guimarães e Joaquim Manuel de Macedo. Revista Eletrônica Cadernos de História, Mariana, v. 7, n. 2, p. 7-26, dez. 2010. Disponível em:

<http://www.ichs.ufop.br/cadernosdehistoria/download/CadernosDeHistoria-10-01.pdf>.

Acesso em: 7 abr. 2012.

AMARAL, Sharyse Piroupo do. Emancipacionismo e as representações do escravo na obra literária de Joaquim Manuel de Macedo. Afro-Asia, Bahia, n. 35, p. 199-236, 2007. Disponível em: <http://redalyc.uaemex.mx/redalyc/pdf/770/77003506.pdf>. Acesso em: 20 abr. 2011.

Uma Nação Por Fazer: escravos, mulheres e educação nos romances de Joaquim Manuel de Macedo. 2001. Dissertação (Mestrado em História) - Instituto de Filosofia e Ciências Humanas, Universidade Estadual de Campinas, Campinas, 2001. Disponível em: <http://www.bibliotecadigital.unicamp.br>. Acesso em: 4 mar. 2010.

AMORA, Antônio Soares. Macedo. In: A Literatura Brasileira. 4. ed. São Paulo: Cultrix, 1973. p. 213-229. v. 2: o romantismo (1833-1838/1878-1881).

ANDRADE, Priscilla Rampin de. Um Cronista na Tribuna: Joaquim Manuel de Macedo imprensa e política na consolidação do Estado-nacional brasileiro. 2011. Dissertação (Mestrado em História Social) - Faculdade de Filosofia, Letras e Ciências Humanas, Universidade de São Paulo, São Paulo, 2011. Disponível em:

$<$ http://www.teses.usp.br/teses/disponiveis/8/8138/tde-25052012-125141/pt-br.php>. Acesso em: 28 nov. 2012.

AUGUSTI, Valéria. O Romance como Guia de Conduta: A Moreninha e Os Dois Amores. 1998. Dissertação (Mestrado em Teoria Literária) - Instituto de Estudos da Linguagem, 
Universidade Estadual de Campinas, Campinas, 1998. Disponível em: <http://www.caminhosdoromance.iel.unicamp.br/estudos/teses/pdfs/valeria.pdf $>$. Acesso em: 30 abr. 2011.

BASSI, Cristina M. Joaquim Manoel de Macedo: o leitor e a leitura no século XIX. 2003. Dissertação (Mestrado em Letras) - Instituto de Estudos da Linguagem, Universidade Estadual de Campinas, Campinas, 2003. Disponível em:

<http://www.bibliotecadigital.unicamp.br>. Acesso em: 13 out. 2011.

BEDÊ, Ana Luiza Reis. Joaquim Manuel de Macedo como folhetinista panfletário: uma leitura de A Carteira de Meu Tio. In: CONGRESSO INTERNACIONAL DA ASSOCIAÇÃO BRASILEIRA DE LITERATURA COMPARADA, 11., 2008, São Paulo. Anais... São Paulo: ABRALIC, 2008. Disponível em:

<http://www.abralic.org.br/anais/cong2008/AnaisOnline/simposios/pdf/075/ANA_BEDE.pdf $>$. Acesso em: 16 abr. 2012.

BOECHAT, Maria Cecília. A moreninha e a tradição cômica do Romantismo brasileiro. Revista do Centro de Estudos Portugueses, Belo Horizonte, v. 25, n. 34, p. 123-129, jan./dez. 2005.

BOSI, Alfredo. Macedo. In: História Concisa da Literatura Brasileira. 2. ed. São Paulo: Cultrix, 1975. p. 143-145.

CABAÑAS, Teresa. O rosto avesso da pieguice. In: MACEDO, Joaquim Manuel de. A Luneta Mágica. São Paulo: Iluminuras, 1997. p. 9-16.

CANDIDO, Antonio. O honrado e facundo Joaquim Manuel de Macedo. In: Formação da Literatura Brasileira: momentos decisivos (1750-1880). 11. ed. Rio de Janeiro: Ouro Sobre Azul, 2007. p. 453-461.

CARDOSO, Eduardo Wright. A Representação Histórica a partir da Obra As Mulheres de Mantilha (1870), ou, uma Aula com o Professor Joaquim Manuel de Macedo. 2008. Monografia (Trabalho de Conclusão de Curso em História) - Instituto de Filosofia e Ciências Humanas, Universidade Federal do Rio Grande do Sul, Porto Alegre, 2008. Disponível em: <http://www.lume.ufrgs.br/bitstream/handle/10183/16074/000695869.pdf?sequence=1>. Acesso em: 2 fev. 2011.

CARNEIRO JÚNIOR, Nelson. As Imagens da Cultura Política Brasileira em A Carteira de Meu Tio de Joaquim Manuel de Macedo. 2008. Dissertação (Mestrado em Sociologia) Faculdade de Ciências Humanas e Filosofia, Universidade Federal de Goiás, Goiânia, 2008. Disponível em: <http://bdtd.ufg.br/tedesimplificado/tde_arquivos/30/TDE-2009-05- 
20T220859Z-129/Publico/Dissertacao\%20Nelson\%20Carneiro\%20Junior.pdf>. Acesso em: 17 nov. 2012.

CASTELlO, José Aderaldo. Produção literária do romantismo de época - $1^{\text {o}}$ : poesia e prosa. In: __ A Literatura Brasileira: origens e unidade. São Paulo: Edusp, 1999. p. 221-257.

COUTINHO, Afrânio; SOUSA, J. Galante de (Dir.). Macedo, Joaquim Manuel de. In: Enciclopédia de Literatura Brasileira. 2. ed. São Paulo: Global Editora; Rio de Janeiro: Biblioteca Nacional; DNL; Academia Brasileira de Letras, 2001. p. 984-985. v. 2.

CRUZ, Eduardo da. Sobre Vítimas e Algozes: Joaquim Manuel de Macedo e a escravidão no século XIX. 2011. Monografia (Trabalho de conclusão de curso em História) - Setor de Ciências Humanas, Letras e Artes, Universidade Federal do Paraná, Curitiba, 2011. Disponível em:

<http://www.historia.ufpr.br/monografias/2011/2_sem_2011/eduardo_cruz.pdf>. Acesso em: 5 nov. 2012.

DUTRA E MELLO, Antonio Francisco. Notícia da Moreninha. In: MACEDO, Joaquim Manoel de. A Moreninha. 9. ed. Rio de Janeiro: H. Garnier, s/d. p. V-XIX. Disponível em: <http://www.caminhosdoromance.iel.unicamp.br>. Acesso em: 17 nov. 2012.

FERRAZ, Maria Cristina Franco; OLIVEIRA, Ana Lucia Machado de; GENS, Rosa Maria de Carvalho. Entre véus, sombras e desejos. In: MACEDO, Joaquim Manuel de. As Mulheres de Mantilha. Rio de Janeiro: Secretaria Municipal de Cultura; Dep. Geral de Doc. e Inf. Cultural, 1988. p. 9-16.

KARAM, Bianca. A Escrita de uma Tradição: Macedinho ou Macedo? 2006. Dissertação (Mestrado em Literatura Brasileira) - Instituto de Letras, Universidade do Estado do Rio de Janeiro, Rio de Janeiro, 2006. Disponível em:

<http://www.bdtd.uerj.br/tde_busca/arquivo.php?codArquivo=156>. Acesso em: 30 set. 2011.

LAJOLO, Marisa Philbert. Os superpoderes de Simplício. In: MACEDO, Joaquim Manuel de. A Luneta Mágica. 4. ed. São Paulo: Ática, 1977. p. 5-6.

LINHARES, Temístocles. Instante de decisão. In: História Crítica do Romance

Brasileiro. Belo Horizonte: Editora Itatiaia; São Paulo: Editora da Universidade de São Paulo, 1987. p. 47-70. v. 1: 1728-1981. 117, jun. 1958.

Macedo e o romance brasileiro. Revista do Livro, [Rio de Janeiro], n. 10, p. 111- 

jun. 1959.

Macedo e o romance brasileiro. Revista do Livro, [Rio de Janeiro], n. 14, p. 97-105, Macedo e o romance brasileiro. Revista do Livro, [Rio de Janeiro], n. 17, p. 127135, mar. 1960.

LOPES, Myriam Bahia; POLITO, Ronald. Posfácio: 27 notas de viagem. In: MACEDO, Joaquim Manuel de. Considerações Sobre a Nostalgia. Campinas: Editora da Unicamp, 2004. p. 111-138.

LUFT, Gabriela; WELTER, Juliane. As personagens negras na literatura brasileira oitocentista: os quadros da escravidão de Joaquim Manuel de Macedo. Terra Roxa e Outras Terras: Revista de Estudos Literários, Londrina, v. 17, n. B, p. 6-17, dez. 2009. Disponível em: <http://www.uel.br/pos/letras/terraroxa/g_pdf/vol17B/TRvol17Ba.pdf>. Acesso em: 5 nov. 2012.

MOISÉS, Massaud. Joaquim Manuel de Macedo. In: História da Literatura

Brasileira. São Paulo: Cultrix; Ed. da Universidade de São Paulo, 1984. p. 78-87. v. 2: romantismo; realismo.

MORAES, Dislane Zerbinatti. A "tagarelice" de Macedo e o ensino de história do Brasil. História, Franca, v. 23, n. 1-2, p. 85-107, 2004. Disponível em:

<http://www.scielo.br/pdf/his/v23n1-2/a06v2312.pdf>. Acesso em: 1 nov. 2012.

PINTO, Fabio Bortolazzo. O outro Macedo. In: MACEDO, Joaquim Manuel de. A Carteira de Meu Tio. 2. ed. Porto Alegre, L\&PM, 2008. p. 7-12.

PROENÇA, M. Cavalcanti. As mulheres de mantilha. In: Estudos Literários. Rio de Janeiro: Livraria José Olympio, 1971. p. 23-25.

QUEIROZ, Juliana Maia de. A carteira de meu tio: ficção e história em Joaquim Manuel de Macedo. Revista Brasileira de História e Ciências Sociais, São Leopoldo, v. 2, n. 3, jul. 2010. Disponível em:

<http://www.rbhcs.com/index_arquivos/Artigo.A\%20carteira\%20de\%20meu\%20tio.pdf $>$.

Acesso em: 30 jul. 2011.

A carteira de meu tio: história e ficção no segundo reinado. Anais do SETA, Campinas, n. 3, p. 532-540, 2009. Disponível em:

<http://www.iel.unicamp.br/revista/index.php/seta/article/view/544/432>. Acesso em: 30 jul. 2011. 
As Múltiplas Facetas de Joaquim Manuel de Macedo: um estudo de A Carteira de Meu Tio, Memórias do Sobrinho de Meu Tio e A Luneta Mágica. 2011. Tese (Doutorado em Teoria e História Literária) - Instituto de Estudos da Linguagem, Universidade Estadual de Campinas, Campinas, 2011. Disponível em: <http://www.bibliotecadigital.unicamp.br>. Acesso em: 30 jul. 2011.

A obra de Joaquim Manuel de Macedo através dos anúncios do Jornal do Comércio do Rio de Janeiro. In: CAMINHOS DO ROMANCE: Brasil - séculos XVIII e XIX. Campinas: Universidade Estadual de Campinas, s/d. Disponível em:

<http://www.caminhosdoromance.iel.unicamp.br>. Acesso em: 12 ago. 2011.

QUEIROZ, Rachel de. Prefácio da edição comemorativa do centenário de "A Moreninha". In: MACEDO, Joaquim Manuel de. A Moreninha. Rio de Janeiro: Edições de Ouro, 1970. p. 1117.

RIBEIRO, José Alcides. Ficção e imprensa no Brasil: os processos de criação de José de Alencar e de Joaquim Manuel de Macedo. Fragmentos de Cultura, Goiânia, v. 9, n. 5, p. 1081-1092, set./out. 1999.

ROMERO, Sílvio. Macedo. In: História da Literatura Brasileira. 6. ed. Rio de Janeiro: Livraria José Olympio, 1960. p. 1399-1463. v. 5: diversas manifestações na prosa; reações antirromânticas na poesia.

RONCARI, Luiz. A Moreninha, de Joaquim Manuel de Macedo. In: Literatura Brasileira: dos primeiros cronistas aos últimos românticos. 2. ed. São Paulo: Edusp, 2002. p. 502-535.

SANTOS, Jocélio Teles dos. "Incorrigíveis, afeminados, desenfreiados": indumentária e travestismo na Bahia do século XIX. Revista de Antropologia, São Paulo, v. 40, n. 2, 1997. Disponível em: <http://www.scielo.br/scielo.php?script=sci_arttext\&pid=S003477011997000200005>. Acesso em: 23 jun. 2010.

SERRA, Tania Rebelo Costa. Joaquim Manuel de Macedo ou os Dois Macedos: a luneta mágica do II Reinado. 2. ed. Brasília: Editora Universidade de Brasília, 2004.

SPERBER, Suzi Frankl. Joaquim Manuel de Macedo e a noção de liberdade. Scripta, Belo Horizonte, v. 6, n. 12, p. 429-439, 1. sem. 2003. Disponível em:

<http://www.ich.pucminas.br/cespuc/Revistas_Scripta/Scripta12/Conteudo/N12_Parte04_art0 1.pdf $>$. Acesso em: 26 out. 2012. 
SÜSSEKIND, Flora. Introdução. In: MACEDO, Joaquim Manuel de. Memórias do Sobrinho de Meu Tio. São Paulo: Companhia das Letras, 1995. p. 7-19.

O sobrinho pelo tio. Literatura e Sociedade, São Paulo, n. 1, p. 30-43, 1996 a.

As vítimas-algozes e o imaginário do medo. In:

Papéis Colados. Rio de Janeiro: UFRJ, 1993. p. 115-138.

TINHORÃO, José Ramos. Joaquim Manuel de Macedo e o romantismo realista. In:

A Música Popular no Romance Brasileiro. Belo Horizonte: Oficina de Livros, 1992. p. 61 92. v. 1: século XVIII - século XIX.

VERÍSSIMO, José. Macedo. In:

História da Literatura Brasileira: de Bento Teixeira (1601) a Machado de Assis (1908). 4. ed. Brasília: Editora Universidade de Brasília, 1963. p. 172-176.

O romancista dos nossos avós. In: Últimos Estudos de Literatura

Brasileira. Belo Horizonte: Itatiaia; São Paulo: Ed. da Universidade de São Paulo, 1979. p. 157-167. 7. série. 


\subsubsection{Bibliografia crítica sobre Camilo e Macedo}

PAVANELO, Luciene Marie. Além do casamento: a representação feminina na ficção camiliana e macediana. In: SEMINÁRIO INTERNACIONAL FAZENDO GÊNERO, 9., 2010, Florianópolis. Anais Eletrônicos... Florianópolis: Universidade Federal de Santa Catarina, 2010. Disponível em:

$<$ http://www.fazendogenero.ufsc.br/9/resources/anais/1277410491_ARQUIVO_LucieneMari ePavanelo-Alemdocasamento.pdf $>$. Acesso em: 9 jan. 2011.

Camilo e Macedo: adesão e repúdio aos modelos na ascensão do romance português e brasileiro. Darandina Revisteletrônica, Juiz de Fora, v. 2, n.3, p. 1-7, dez. 2009. Disponível em: <http://www.ufjf.br/darandina/files/2010/01/Luciene-Marie-Pavanelo.pdf>. Acesso em: 3 fev. 2010.

Deslocamentos atlânticos segundo Camilo e Macedo: um mundo além do espaço nacional. In: COLÓQUIO DO PPRLB, O ATLÂNTICO COMO PONTE: A EUROPA E O ESPAÇO LUSÓFONO, 5., 2010, Rio de Janeiro. Atas... Rio de Janeiro: Real Gabinete Português de Leitura, 2010. Disponível em:

<http://www.mygead.com/geadmedia/packages/giadrgpl_rgpl/documentsmain/201010191213 72849b_lucienemariepavaoriginal.pdf>. Acesso em: 20 dez. 2011.

Lunetas mágicas e esqueletos: o insólito na ficção macediana e camiliana. In: PAINEL REFLEXÕES SOBRE O INSÓLITO NA NARRATIVA FICCIONAL; ENCONTRO REGIONAL DO INSÓLITO COMO QUESTÃO NA NARRATIVA FICCIONAL: O INSÓLITO E SEU DUPLO, 6., 2009, Rio de Janeiro. Anais... Rio de Janeiro: Dialogarts, 2009. p. 156-164. Disponível em:

<http://www.dialogarts.uerj.br/arquivos/o_insolito_e_seu_duplo_comunicacoes_livres.pdf >. Acesso em: 4 jun. 2010.

Mero entretenimento? A realidade social sob os olhares camiliano e macediano. In: CONGRESSO INTERNACIONAL DA ASSOCIAÇÃO BRASILEIRA DE PROFESSORES DE LITERATURA PORTUGUESA, 22., 2009, Salvador. Anais... Salvador: ABRAPLIP, 2009. p. 1982-1991. Disponível em:

$<$ http://abraplip.org/anais_abraplip/documentos/comunicacoes_orais/luciene_marie_pavanelo. pdf>. Acesso em: 20 dez. 2010.

Repensando paradigmas: a visão camiliana e macediana sobre o discurso naturalista. In: COLÓQUIO DA LUSOFONIA, 13., ENCONTRO AÇORIANO, 5., 2010, Florianópolis. Atas/Anais... Florianópolis: Colóquios da Lusofonia, 2010. p. 252-261. 1 CD-ROM. 
Resgatando best-sellers oitocentistas: uma releitura de $A$ Moreninha e Amor de Perdição. In: CONGRESSO INTERNACIONAL DA ASSOCIAÇÃO BRASILEIRA DE LITERATURA COMPARADA, 12., 2011, Curitiba. Anais... Curitiba: ABRALIC, 2011. Disponível em: <http://www.abralic.org.br/anais/cong2011/AnaisOnline/resumos/TC02871.pdf >. Acesso em: 11 dez. 2011.

Os subgêneros romanescos na ficção camiliana e macediana. In: ENCONTRO DE PÓS-GRADUANDOS DA FACULDADE DE FILOSOFIA, LETRAS E CIÊNCIAS HUMANAS, 5., 2010, São Paulo. Anais... São Paulo: FFLCH/USP, 2010. 1 CD-ROM. 


\subsection{Títulos teórico-críticos sobre o período da ascensão do romance, seus subgêneros e o mercado editorial oitocentista}

ABREU, Márcia. Os Caminhos dos Livros. Campinas: Mercado de Letras, 2003.

Leituras no Brasil colonial. Remate de Males, Campinas, n. 22, p. 131-163, 2002. Disponível em: <http://www.caminhosdoromance.iel.unicamp.br/estudos/ensaios/leiturasreading-br.pdf $>$. Acesso em: 13 ago. 2011.

ABREU, Márcia et al. Caminhos do romance no Brasil: séculos XVIII e XIX. In: CAMINHOS DO ROMANCE: Brasil - séculos XVIII e XIX. Campinas: Universidade Estadual de Campinas, s/d. Disponível em:

<http://www.caminhosdoromance.iel.unicamp.br>. Acesso em: 12 ago. 2011.

ALENCAR, Heron de. José de Alencar e a ficção romântica. In: COUTINHO, Afrânio (Dir.). A Literatura no Brasil. 6. ed. São Paulo: Global, 2002. p. 231-321. v. 3; parte 2: estilos de época - era romântica.

ALMEIDA, Leandro Thomaz de. Apontamentos iniciais para uma investigação sobre o papel da moral nos romances naturalistas brasileiros. Anais do SETA, Campinas, n. 4, p. 611-621, 2010b. Disponível em:

<http://www.iel.unicamp.br/revista/index.php/seta/article/view/894/696>. Acesso em: 28 out. 2012.

ALMEIDA, Raphael Rocha de. Romances e a formação de um clima de opinião no Rio de Janeiro de 1794. In: ABREU, Márcia (Org.). Trajetórias do Romance: circulação, leitura e escrita nos séculos XVIII e XIX. Campinas: Mercado de Letras, 2008. p. 329-350.

ALMEIDA, Sérgio Rubens B. de. Romance: II - no Brasil. In: BIBLOS: Enciclopédia Verbo das Literaturas de Língua Portuguesa. Lisboa; São Paulo: Verbo, s/d. p. 927-931. v. 4.

AMORA, Antônio Soares. Promoção europeia do Brasil americano, anticlássico e antieuropeu. In: . A Literatura Brasileira. 4. ed. São Paulo: Cultrix, 1973. p. 57-74. v. 2: o romantismo (1833-1838/1878-1881). 
ARARIPE JÚNIOR, Tristão de Alencar. Obra Crítica de Araripe Júnior. Dirigida por Afrânio Coutinho. Rio de Janeiro: Ministério da Educação e Cultura; Casa de Rui Barbosa, 1958. v. 1: 1868-1887.

Obra Crítica de Araripe Júnior. Dirigida por Afrânio Coutinho. Rio de Janeiro: Ministério da Educação e Cultura; Casa de Rui Barbosa, 1960. v. 2: 1888-1894.

AUERBACH, Erich. Mimesis: a representação da realidade na literatura ocidental. 4. ed. São Paulo: Perspectiva, 2002.

AUGUSTI, Valéria. Polêmicas literárias e mercado editorial Brasil-Portugal na segunda metade do século XIX. In: SEMINÁRIO BRASILEIRO SOBRE LIVRO E HISTÓRIA EDITORIAL, 1., 2004, Rio de Janeiro. Disponível em:

<http://www.livroehistoriaeditorial.pro.br/pdf/valeriaaugusti.pdf >. Acesso em: 13 ago. 2011.

Trajetórias de Consagração: discursos da crítica sobre o romance no Brasil oitocentista. 2006. Tese (Doutorado em Teoria e História Literária) - Instituto de Estudos da Linguagem, Universidade Estadual de Campinas, Campinas, 2006. Disponível em: <http://www.bibliotecadigital.unicamp.br>. Acesso em: 13 ago. 2011.

BARDÈCHE, Maurice. Balzac, Romancier: la formation de l'art du roman chez Balzac jusqu'à la publication du "Père Goriot" (1820-1835). Genève: Slatkine Reprints, 1967.

BAREL, Ana Beatriz Demarchi. Um Romantismo a Oeste: modelo francês, identidade nacional. São Paulo: Annablume; Fapesp, 2002.

BASTOS, Alcmeno. O romance histórico no romantismo brasileiro (além de Alencar). In: ALCMENO BASTOS. Disponível em: <http://www.alcmeno.com/wordpress/wpcontent/arquivos/romance-historico-no-romantismo2.pdf>. Acesso em: 2 fev. 2011.

BIESTER, Ernesto. Uma Viagem pela Literatura Contemporânea: oferecida ao senhor Alexandre Herculano. Lisboa: Tipografia do Panorama, 1856.

BRAGA, Teófilo. História do Romantismo em Portugal. Lisboa: Ulmeiro, 1984.

BRAYNER, Sónia. Naturalismo - II: no Brasil. In: BIBLOS: Enciclopédia Verbo das Literaturas de Língua Portuguesa. Lisboa; São Paulo: Verbo, s/d. p. 1051-1053. v. 4. 
BROCA, Brito. Uma fantasia filosófica. In: Pontos de Referência. Rio de Janeiro: MEC, 1962. p. 32-36

Românticos, Pré-românticos, Ultrarromânticos. 3. ed. São Paulo: Polis; Instituto Nacional do Livro; Ministério da Educação e Cultura, 1979.

BROOKSHAW, David. Raça e Cor na Literatura Brasileira. Tradução Marta Kirst. Porto Alegre: Mercado Aberto, 1983.

BRUNO, Sampaio. A Geração Nova: ensaios críticos - os novelistas. Porto: Magalhães \& Moniz, 1886.

BUESCU, Helena Carvalhão. Narrativa de atualidade. In: BUESCU, Helena Carvalhão (Coord.). Dicionário do Romantismo Literário Português. Lisboa: Caminho, 1997. p. 340346.

Narrativa histórica. In: BUESCU, Helena Carvalhão (Coord.). Dicionário do Romantismo Literário Português. Lisboa: Caminho, 1997. p. 356-362.

BURGELIN, Claude. Roman historique. In: MICHEL, Albin (Org.). Dictionnaire des Genres et Notions Littéraires. Paris: Encyclopaedia Universalis, s/d. p. 662-663.

CAILLOIS, Roger. Fantastique. In: MICHEL, Albin (Org.). Dictionnaire des Genres et Notions Littéraires. Paris: Encyclopaedia Universalis, s/d. p. 289-299.

CAMILO, Vagner. Risos entre Pares: poesia e humor românticos. São Paulo: Edusp, 1998.

CANDIDO, Antonio. A educação pela noite. In: A Educação pela Noite e Outros Ensaios. 2. ed. São Paulo: Ática, 1989. p. 10-22.

De cortiço a cortiço. In: O Discurso e a Cidade. 3. ed. São Paulo; Rio de Janeiro: Duas Cidades; Ouro sobre Azul, 2004. p. 105-129.

CARPEAUX, Otto Maria. História da Literatura Ocidental. Rio de Janeiro: O Cruzeiro, 1962. v. 4; parte 7: o romantismo. 
CARVALHO, Francisco Freire de. Lições Elementares de Eloquência Nacional: para uso da mocidade de ambos os hemisférios, que fala o idioma português. 5. ed. Lisboa: Tipografia Rollandiana, 1856.

Lições Elementares de Poética Nacional: seguidas de um breve ensaio sobre a crítica literária, para uso da mocidade de ambos os hemisférios, que fala o idioma português. 2. ed. Lisboa: Tipografia Rollandiana, 1851.

CASTRO, Aníbal Pinto de. Viagens (Literatura de). In: BIBLOS: Enciclopédia Verbo das Literaturas de Língua Portuguesa. Lisboa; São Paulo: Verbo, s/d. p. 779-790. v. 4.

CÉSAR, Guilhermino. O "Brasileiro" na Ficção Portuguesa: o direito e o avesso de uma personagem-tipo. Lisboa: Parceria A. M. Pereira, 1969.

CÉSAR, Guilhermino (Sel.). Historiadores e Críticos do Romantismo: a contribuição europeia - crítica e história literária. Rio de Janeiro: Livros Técnicos e Científicos; São Paulo: EDUSP, 1978. v. 1.

CESERANI, Remo. O Fantástico. Tradução de Nilton Cezar Tridapalli. Curitiba: Editora da UFPR, 2006.

CHAGAS, M. Pinheiro. Ensaios Críticos. Porto: Casa de Viúva Moré, 1866.

CHAVES, Castelo Branco. O Romance Histórico no Romantismo Português. Amadora: Instituto de Cultura Portuguesa; Secretaria de Estado da Cultura; Ministério da Cultura e da Ciência, 1979.

CHEVREL, Yves. Naturalisme. In: MICHEL, Albin (Org.). Dictionnaire des Genres et Notions Littéraires. Paris: Encyclopaedia Universalis, s/d. p. 486-495.

COELHO, Jacinto do Prado (Dir.). Dicionário de Literatura: Literatura Portuguesa, Literatura Brasileira, Literatura Galega, Estilística Literária. 3. ed. Porto: Figueirinhas, 1981.

COMTE, Auguste. Curso de filosofia positiva; Discurso preliminar sobre o conjunto do positivismo; Catecismo positivista. In: OS PENSADORES. São Paulo: Nova Cultural, 2000.

CONCEIÇÃO, Alexandre da. Notas: ensaios de crítica e de literatura. Coimbra: Imprensa Acadêmica, 1881. 
CORDEIRO, Luciano. Livro de Crítica: arte e literatura portuguesa d'hoje, 1868-1869. Porto: Tipografia Lusitana, 1869.

COUTINHO, Afrânio. A crítica naturalista e positivista. In: COUTINHO, Afrânio (Dir.). A Literatura no Brasil. 6. ed. São Paulo: Global, 2002. v. 4, parte 2: estilos de época - era realista; era de transição.

CRISTÓVÃO, Fernando. Para uma teoria da Literatura de Viagens. In: CRISTÓVÃO, Fernando (Coord.). Condicionantes Culturais da Literatura de Viagens: estudos e bibliografias. Coimbra: Almedina; Centro de Literaturas de Expressão Portuguesa da Universidade de Lisboa, 2002. p. 13-52.

A Literatura de Viagens e a História Natural. In: CRISTÓVÃO, Fernando (Coord.). Condicionantes Culturais da Literatura de Viagens: estudos e bibliografias. Coimbra: Almedina; Centro de Literaturas de Expressão Portuguesa da Universidade de Lisboa, 2002. p. 183-218.

CUNHA, Carlos Manuel Ferreira da. A Construção do Discurso da História Literária na Literatura Portuguesa do Século XIX. Braga: Universidade do Minho; Centro de Estudos Humanísticos, 2002.

CUNHA, Cilaine Alves. O Belo e o Disforme: Álvares de Azevedo e a ironia romântica. São Paulo: Edusp; FAPESP, 1998.

A fundação da literatura brasileira em Noite na Taverna. Itinerários, Araraquara, $\mathrm{n}$. 22, p. 115-133, 2004. Disponível em:

<http://seer.fclar.unesp.br/itinerarios/article/view/2784/2520>. Acesso em: 5 jan. 2013.

DENIS, Ariel. Roman d'aventures. In: MICHEL, Albin (Org.). Dictionnaire des Genres et Notions Littéraires. Paris: Encyclopaedia Universalis, s/d. p. 648-656.

DUARTE, Maria do Rosário Cunha. Rejeição e recepção das ideias francesas na literatura portuguesa. Letras de Hoje, Porto Alegre, v. 43, n. 4, p. 65-68, out./dez. 2008. Disponível em: <http://revistaseletronicas.pucrs.br/ojs/index.php/fale/article/viewFile/5629/4103>.

Acesso em: 15 out. 2012.

EL FAR, Alessandra. Páginas de Sensação: literatura popular e pornográfica no Rio de Janeiro (1870-1924). São Paulo: Companhia das Letras, 2004. 
FERREIRA, J. M. de Andrade. Poesia popular. Revista Contemporânea de Portugal e Brasil, Lisboa, ano 1, p. 512-519, abr. 1859.

FERREIRA, Tania Maria Tavares Bessone da Cruz; NEVES, Lúcia Maria Bastos Pereira das. As relações culturais ao longo do século XIX. In: CERVO, Amado Luiz; MAGALHÃES, José Calvet de (Orgs.). Depois das Caravelas: as relações entre Portugal e Brasil 1808-2000. Brasília: IBRI; Editora UnB, 2000. p. 225-252.

FIGUEIREDO, Fidelino de. Romance histórico. In: Literatura Portuguesa: desenvolvimento histórico das origens à atualidade. Rio de Janeiro: A Noite, 1941. p. 277280.

Romance passional. In: Literatura Portuguesa: desenvolvimento histórico das origens à atualidade. Rio de Janeiro: A Noite, 1941. p. 280-284.

FRANÇA, José-Augusto. Perspectiva do romantismo português. In: MACHADO, Álvaro Manuel et al. História da Literatura Portuguesa. Mem Martins: Publicações Alfa, 2003. p. 45-60. v. 4.

FURTADO, Filipe. A Construção do Fantástico na Narrativa. Lisboa: Livros Horizonte, 1980.

GOIMARD, Jacques. Merveilleux. In: MICHEL, Albin (Org.). Dictionnaire des Genres et Notions Littéraires. Paris: Encyclopaedia Universalis, s/d. p. 456-467.

GOMES, Renato Cordeiro. A herança portuguesa como provocação à identidade cultural brasileira. In: SANTOS, Gilda (Org.). Brasil e Portugal: 500 anos de enlaces e desenlaces. Rio de Janeiro: Real Gabinete Português de Leitura, 2000.

GUEDES, Fernando. O Livro e a Leitura em Portugal: subsídios para a sua história séculos XVIII e XIX. Lisboa; São Paulo: Verbo, 1987.

GUINSBURG, J. (Org). O Romantismo. 4. ed. São Paulo: Perspectiva, 2002.

HANSEN, João Adolfo. "O imortal" e a verossimilhança. Teresa: Revista de Literatura Brasileira, São Paulo, n. 6-7, p. 56-78, 2006. Disponível em:

<http://www.fflch.usp.br/dlcv/lb/images/stories/revista_teresa/teresa67.pdf>. Acesso em: 3 out. 2011. 
HAUSER, Arnold. História Social da Arte e da Literatura. Tradução de Álvaro Cabral. São Paulo: Martins Fontes, 2003.

HEINEBERG, Ilana. Miméticos, aclimatados e transformadores: trajetórias do romancefolhetim em diários fluminenses. In: ABREU, Márcia (Org.). Trajetórias do Romance: circulação, leitura e escrita nos séculos XVIII e XIX. Campinas: Mercado de Letras, 2008. p. 497-522.

HUTCHEON, Linda. Historiographic metafiction. In: MCKEON, Michael (Ed.). Theory of the Novel: a historical approach. Baltimore; London: The John Hopkins University Press, [2000?]. p. 830-850.

JESUS, Maria Saraiva de. Do "mineiro" do século XVIII ao "brasileiro" do século XIX. Revista da Universidade de Aveiro: Letras, Aveiro, n. 16, p. 77-97, 1999.

JÚDICE, Nuno. A viagem na literatura portuguesa. Prelo, Lisboa, n. 19, p. 47-59, jan./mar. 1991.

LUKÁCS, György. O Romance Histórico. Tradução de Rubens Enderle. São Paulo: Boitempo, 2011.

MACHADO, Álvaro Manuel. Do Romantismo aos Romantismos em Portugal: ensaios de tipologia comparativista. Lisboa: Presença, 1996.

O "Francesismo" na Literatura Portuguesa. Amadora: Biblioteca Breve; Instituto de Cultura e Língua Portuguesa, 1983.

Les Romantismes au Portugal: modeles etrangers et orientations nationales. Paris: Fondation Calouste Gulbenkian; Centre Culturel Portugais, 1986.

MAGALHÃES, Valentim. A Literatura Brasileira: 1870-1895. Lisboa: Livraria de Antonio Maria Pereira, 1896.

MARCO, Valéria de. A Perda das Ilusões: o romance histórico de José de Alencar. Campinas: Editora da Unicamp, 1993.

MARINHO, Maria de Fátima. O romance histórico de Alexandre Herculano. Línguas e Literaturas: Revista da Faculdade de Letras do Porto, Porto, v. 9, p. 97-117, 1992. Disponível em: <http://ler.letras.up.pt/uploads/ficheiros/2643.pdf>. Acesso em: 10 ago. 2012. 
Romance histórico: I - em Portugal. In: BIBLOS: Enciclopédia Verbo das Literaturas de Língua Portuguesa. Lisboa; São Paulo: Verbo, s/d. p. 932-940. v. 4.

MARQUES, Ana Maria dos Santos. O Anacronismo no Romance Histórico Português Oitocentista. [2010?]. Dissertação (Doutorado em Literaturas e Culturas Românicas) Faculdade de Letras, Universidade do Porto, Porto, 2010. Disponível em: <http://repositorioaberto.up.pt/bitstream/10216/39321/2/tesedoutanamarques000112487.pdf >. Acesso em: 10 ago. 2012.

MARTINS, Wilson. História da Inteligência Brasileira. São Paulo: Cultrix; Ed. da Universidade de São Paulo, 1977a. v. 2: 1794-1855.

História da Inteligência Brasileira. São Paulo: Cultrix; Ed. da Universidade de São Paulo, 1977b. v. 3: 1855-1877. 1896.

História da Inteligência Brasileira. São Paulo: T. A. Queiroz, 1996. v. 4: 1877-

MENDES, Maria Lúcia Dias. Amor e Encenação em La reine Margot, de Alexandre Dumas. 2002. Dissertação (Mestrado em Língua e Literatura Francesa) - Faculdade de Filosofia, Letras e Ciências Humanas, Universidade de São Paulo, São Paulo, 2002.

MENDONÇA, A. P. Lopes de. Memórias de Literatura Contemporânea. Lisboa: Tipografia do Panorama, 1855.

MEYER, Marlyse. Um eterno retorno: as descobertas do Brasil. In: . Caminhos do Imaginário no Brasil. São Paulo: Edusp, 1993. p. 19-46.

Folhetim: uma história. São Paulo: Companhia das Letras, 1996.

MOISÉS, Massaud. Romantismo. In: A Literatura Portuguesa. 32. ed. São Paulo: Cultrix, 2003. p. 111-156.

MONTANDON, Alain. Le Roman au XVIII ${ }^{\text {e }}$ Siècle en Europe. Paris: Presses Universitaires de France, 1999.

MONTEIRO, Ofélia Paiva. Romantismo e romantismos. In: MACHADO, Álvaro Manuel et al. História da Literatura Portuguesa. Mem Martins: Publicações Alfa, 2003. p. 9-43. v. 4. 
MOREIRA, Maria Eunice. Gonçalves Dias na crítica portuguesa do século XIX: primeiros registros. In: CONGRESSO DA ASSOCIAÇÃO INTERNACIONAL DE LUSITANISTAS, 8., 2005, Santiago de Compostela. Actas... Santiago de Compostela: Associação Internacional de Lusitanistas, 2005. p. 279-284. 1 CD-ROM.

. Relações ambíguas: a recepção dos românticos brasileiros pela crítica portuguesa do século XIX. Triceversa: Revista do Centro Ítalo-Luso-Brasileiro de Estudos Linguísticos e Culturais, Assis, v.1, n.1, p. 35-44, maio-out. 2007. Disponível em:

<http://www2.assis.unesp.br/cilbelc/triceversa/publicacao/ed1/mariaeunicemoreira.pdf $>$.

Acesso em: 28 fev. 2012.

MORETTI, Franco. Atlas do Romance Europeu: 1800-1900. Tradução de Sandra Guardini Vasconcelos. São Paulo: Boitempo, 2003a.

Gráficos. In:

A Literatura Vista de Longe. Tradução de Anselmo Pessoa Neto. Porto Alegre: Arquipélago, 2008. p. 7-60.

O século sério. Novos Estudos, São Paulo, n. 65, p. 3-33, mar. 2003b. Tradução de Alípio Correa e Sandra Correa. Disponível em:

<http://www.novosestudos.com.br/v1/files/uploads/contents/99/20080627_seculo_serio.pdf>. Acesso em: 22 set. 2011.

NEMÉSIO, Vitorino. Relações Francesas do Romantismo Português. Coimbra: Biblioteca Geral da Universidade, 1936.

NEVES, João Alves das. As Relações Literárias de Portugal com o Brasil. Lisboa: Biblioteca Breve, 1992.

NEVES, Lúcia Maria Bastos P. Brasil e Portugal: imagens e percepções distintas entre povos irmãos ao longo da primeira metade do oitocentos. Revista Convergência Lusíada, Rio de Janeiro, n. 21, p. 149-164, 2005.

NODIER, Charles. Du fantastique en littérature. In: Oeuvres de Charles Nodier: romans, contes et nouvelles. Paris: Librairie D'Eugène Renduel, 1832. p. 67-112. v. 5: rêvéries.

OLIVEIRA, Paulo Motta. A ascensão do romance em português: para além das histórias literárias nacionais. Veredas, Santiago de Compostela; Galiza, v. 10, p. 173-181, dez. 2008a. 
E a imprensa chegou ao Brasil: reflexões sobre livros, invasões e mercados. In: COLÓQUIO DO PPRLB: D. JOÃO VI E O OITOCENTISMO, 4., 2008, Rio de Janeiro. Atas... Rio de Janeiro: Real Gabinete Português de Leitura, 2008b. Disponível em: <http://www.realgabinete.com.br/geadmedia/mediapackages/giadrgpl_rgpl/documentsmain/2 0110922124894736e_paulomottaoliveioriginal.pdf>. Acesso em: 15 mar. 2012.

A mão do finado: as extraordinárias aventuras de um sucesso mundial. In: SEMINÁRIO BRASILEIRO LIVRO E HISTÓRIA EDITORIAL, 2., 2009, Niterói. Seminário... Niterói, 2009. Disponível em:

<http://www.livroehistoriaeditorial.pro.br/ii_pdf/paulo_oliveira_mota.pdf $>$. Acesso em: 26 ago. 2011.

. Não iluminada, talvez romântica: a tradição gótica no Portugal oitocentista. In: COLÓQUIO DO PPRLB: ENTRE ILUMINADOS E ROMÂNTICOS, 3., 2006, Rio de Janeiro. Atas... Rio de Janeiro: Real Gabinete Português de Leitura, 2006. Disponível em: <http://www.realgabinete.com.br/geadmedia/mediapackages/giadrgpl_rgpl/documentsmain/2 01110311051062812_paulomottaoliveioriginal.pdf>. Acesso em: 29 set. 2009.

ORLANDO, Francesco. Estatutos do sobrenatural na narrativa. In: MORETTI, Franco (Org.). O Romance: a cultura do romance. Tradução de Denise Bottmann. São Paulo: Cosac Naify, 2009. p. 245-281. v. 1.

OUTEIRINHO, Fátima. Um estudo de caso: a narrativa de viagem oitocentista. Cadernos de Literatura Comparada: para uma crítica do discurso crítico - narrativa literária e identidade, Porto, n. 1, p. 101-118, dez. 2000. Disponível em: <http://aleph20.letras.up.pt>. Acesso em: 22 out. 2012.

PAVANELO, Luciene Marie. A literatura brasileira sob o olhar do escritor português oitocentista: pontes e polêmicas. In: COLÓQUIO DO PPRLB, PORTUGAL NO BRASIL: PONTES PARA O PRESENTE, 6., 2012, Rio de Janeiro. Atas... Rio de Janeiro: Real Gabinete Português de Leitura. No prelo.

Romance, um gênero sem fronteiras: o mercado editorial luso-brasileiro. In: CONGRESSO INTERNACIONAL DA ASSOCIAÇÃO BRASILEIRA DE PROFESSORES DE LITERATURA PORTUGUESA, 23., 2011, São Luís. Anais... São Luís: ABRAPLIP, 2011. p. 2169-2177. Disponível em:

<http://www.abraplip.org/anais_abraplip/images/stories/sessoes/Luciene\%20Marie\%20Pavan eloo.pdf $>$. Acesso em 2 dez. 2012.

Soares de Passos, Álvares de Azevedo e as diversas faces do ultrarromantismo. Revista Crioula, São Paulo, n. 5, maio 2009. Disponível em:

$<$ http://www.fflch.usp.br/dlcv/revistas/crioula/edicao/05/Artigos\%20e\%20Ensaios\%20-

\%20Luciene\%20Pavanelo.pdf>. Acesso em: 5 jan. 2010. 
PAZ, Octavio. Os Filhos do Barro: do romantismo à vanguarda. Tradução de Olga Savary. Rio de Janeiro: Nova Fronteira, 1984.

PIMENTEL, Alberto. Vinte Anos de Vida Literária. Lisboa: Parceria de Antonio Maria Pereira, s/d.

PINHEIRO, Joaquim Caetano Fernandes. Curso Elementar de Literatura Nacional. Rio de Janeiro: Livraria de B. L. Garnier, 1862.

PINTO, A. Silva. Controvérsias e Estudos Literários: 1875-1878. Porto: Imprensa Comercial de Santos Corrêa e Mathias, 1878.

PINTO, Júlio Lourenço. Do método a seguir: na aplicação do realismo à arte. Revista de Estudos Livres, Lisboa, n. 1, p. 35-40; 78-82; 116-119, 1883-1884.

PRAZ, Mario. A Carne, a Morte e o Diabo na Literatura Romântica. Tradução de Philadelpho Menezes. Campinas: Editora da UNICAMP, 1996.

RAZZINI, Marcia de Paula Gregorio. O Espelho da Nação: a Antologia Nacional e o ensino de português e de literatura (1838-1971). 2000. Tese (Doutorado em Teoria Literária) Instituto de Estudos da Linguagem, Universidade Estadual de Campinas, Campinas, 2000. Disponível em: <www.unicamp.br/iel/memoria/projetos/teses/tese21.doc>. Acesso em: 10 ago. 2011.

REMÉDIOS, Mendes dos. História da Literatura Portuguesa: desde as origens até a atualidade. 3. ed. Coimbra: F. França Amado, 1908.

REIS, Carlos. Narrativa de viagens. In: BUESCU, Helena Carvalhão (Coord.). Dicionário do Romantismo Literário Português. Lisboa, Caminho, 1997. p. 353-356.

Naturalismo: I - em Portugal. In: BIBLOS: Enciclopédia Verbo das Literaturas de Língua Portuguesa. Lisboa; São Paulo: Verbo, s/d. p. 1045-1051. v. 4.

RIBEIRO, Maria Aparecida. Romance histórico: II - no Brasil. In: BIBLOS: Enciclopédia Verbo das Literaturas de Língua Portuguesa. Lisboa; São Paulo: Verbo, s/d. p. 940-946. v. 4.

RIBEIRO, Maria Manuela Tavares. Livros e Leituras no Século XIX. Revista de História das Ideias, Coimbra, v. 20, p. 187-227, 1999. 
ROCHETA, Maria Isabel. Narrativa passional. In: BUESCU, Helena Carvalhão (Coord.). Dicionário do Romantismo Literário Português. Lisboa: Caminho, 1997. p. 365-367.

RODRIGUES, A. Gonçalves. A Novelística Estrangeira em Versão Portuguesa no Período Pré-Romântico. Coimbra: Biblioteca da Universidade, 1951.

A Tradução em Portugal: tentativa de resenha cronológica das traduções impressas em língua estrangeira excluindo o Brasil de 1495 a 1950. Lisboa: Imprensa Nacional; Casa da Moeda, 1992. v. 1: 1495-1834.

A Tradução em Portugal: tentativa de resenha cronológica das traduções impressas em língua estrangeira excluindo o Brasil de 1495 a 1950. Lisboa: Instituto de Cultura e Língua Portuguesa, 1992. v. 2: 1835-1850.

A Tradução em Portugal: tentativa de resenha cronológica das traduções impressas em língua estrangeira excluindo o Brasil de 1495 a 1950. Lisboa: ISLA, 1993. v. 3: 18511870.

A Tradução em Portugal: tentativa de resenha cronológica das traduções impressas em língua estrangeira excluindo o Brasil de 1495 a 1950. Lisboa: ISLA, 1994. v. 4: 18711900.

RODRIGUES, Ernesto. Alexandre, o conquistador. In: RÊGO, Manuela; CASTELOBRANCO, Miguel (Coords.). Antes das Playstations: 200 anos do romance de aventuras em Portugal. Lisboa: Biblioteca Nacional, 2003.

ROMERO, Sílvio. O Naturalismo em Literatura. São Paulo: Tipografia da Província de São Paulo, 1882. Disponível em: <http://www.brasiliana.usp.br/bbd/handle/1918/01615000>. Acesso em: 30 set. 2011.

Novos Estudos de Literatura Contemporânea. Rio de Janeiro: H. Garnier, 1898. Disponível em: <http://www.brasiliana.usp.br/bbd/handle/1918/01616000>. Acesso em: 30 set. 2011.

Outros Estudos de Literatura Contemporânea. Lisboa: Tipografia da A. Editora, 1906. Disponível em: <http://www.brasiliana.usp.br/bbd/handle/1918/01616100>. Acesso em: 30 set. 2011.

ROUDAUT, Jean. Récit de voyage. In: MICHEL, Albin (Org.). Dictionnaire des Genres et Notions Littéraires. Paris: Encyclopaedia Universalis, s/d. p. 587-599. 
SACRAMENTO BLAKE, Augusto Victorino Alves. Dicionário Bibliográfico Brasileiro. Rio de Janeiro: Imprensa Nacional, 1898.

SALES, Germana Maria Araújo. Palavra e Sedução: uma leitura dos prefácios oitocentistas (1826-1881). 2003. Tese (Doutorado em Teoria e História Literária) - Instituto de Estudos da Linguagem, Universidade Estadual de Campinas, Campinas, 2003. Disponível em: <http://www.bibliotecadigital.unicamp.br>. Acesso em: 30 nov. 2012.

SANTANA, Maria Helena. Literatura e Ciência na Ficção do Século XIX: a narrativa naturalista e pós-naturalista portuguesa. Lisboa: Imprensa Nacional; Casa da Moeda, 2007.

SCHWARCZ, Lilia Moritz. Espetáculo da miscigenação. Estudos Avançados, São Paulo, v. 8, n. 20, p. 137-152, jan./abr. 1994. Disponível em:

<http://www.scielo.br/pdf/ea/v8n20/v8n20a17.pdf >. Acesso em: 4 out. 2011.

O Espetáculo das Raças: cientistas, instituições e questão racial no Brasil (18701930). São Paulo: Companhia das Letras, 1993.

SCHWARZ, Roberto. Ao Vencedor as Batatas: forma literária e processo social nos inícios do romance brasileiro. 5. ed. São Paulo: Duas Cidades; Editora 34, 2000a.

Um Mestre na Periferia do Capitalismo: Machado de Assis. 4. ed. São Paulo: Duas Cidades, Editora 34, 2000b.

SHAW, Harry E. The historical novel. In: COYLE, Martin et al. (Ed.). Encyclopedia of Literature and Criticism. London: Routledge, 1991. p. 531-543.

SILVA, Guilherme Sarmiento da. Dinâmica das Almas: fantasmagoria romântica no Brasil (1830-1850). 2009. Tese (Doutorado em Letras) - Departamento de Letras, Pontifícia Universidade Católica do Rio de Janeiro, Rio de Janeiro, 2009. Disponível em: $<$ http://www.maxwell.lambda.ele.pucrio.br/Busca_etds.php?strSecao=resultado\&nrSeq=13393@2>. Acesso em: 1 out. 2009.

SILVA, Hebe Cristina da. A ascensão do romance no Brasil: considerações acerca da presença do gênero em anúncios do Jornal do Comércio. In: CAMINHOS DO ROMANCE: Brasil - séculos XVIII e XIX. Campinas: Universidade Estadual de Campinas, s/d. Disponível em: 〈http://www.caminhosdoromance.iel.unicamp.br〉. Acesso em: 12 ago. 2011. 
A busca da moral: considerações acerca da crítica de romances na imprensa brasileira oitocentista. In: SEMINÁRIO DO GEL, 53., 2005, São Carlos. Estudos Linguísticos XXXV. São Carlos: UFSCAR, 2006. p. 884-892.

SOBREIRA, Luís. Uma imagem do campo literário português no período romântico através dos best-sellers produzidos entre 1840 e 1860. In: CONGRESSO INTERNACIONAL DA ASSOCIAÇÃO PORTUGUESA DE LITERATURA COMPARADA, 4., Évora. IV Congresso... Évora: Associação Portuguesa de Literatura Comparada, 2001. p. 1-16.

SODRÉ, Nélson Werneck. História da Literatura Brasileira. 10. ed. Rio de Janeiro: Graphia, 2002.

O Naturalismo no Brasil. 2. ed. Belo Horizonte: Oficina de Livros, 1992.

SOUSA, Maria Leonor Machado de. Fantástico. In: BIBLOS: Enciclopédia Verbo das Literaturas de Língua Portuguesa. Lisboa; São Paulo: Verbo, s/d. p. 468-471. v. 4.

O "Horror" na Literatura Portuguesa. Amadora: Biblioteca Breve; Instituto de Cultura Portuguesa, 1979.

. A Literatura "Negra” ou “de Terror” em Portugal: séculos XVIII e XIX. Lisboa: Novaera, 1978.

Narrativa de terror. In: BUESCU, Helena Carvalhão (Coord.). Dicionário do Romantismo Literário Português. Lisboa: Caminho, 1997. p. 346-353.

SOUZA, Simone Cristina Mendonça de. "Sahiram à luz": livros em prosa de ficção publicados pela Impressão Régia do Rio de Janeiro. In: ABREU, Márcia (Org.). Trajetórias do Romance: circulação, leitura e escrita nos séculos XVIII e XIX. Campinas: Mercado de Letras, 2008. p. 23-44.

STALlONI, Yves. Dictionnaire du Roman. Paris: Armand Colin, 2006.

SÜSSEKIND, Flora. O Brasil Não É Longe Daqui: o narrador, a viagem. São Paulo: Companhia das Letras, 1990.

Palavras loucas, orelhas moucas: os relatos de viagem dos românticos brasileiros. Revista USP, São Paulo, n. 30, p. 94-107, jun./ago. 1996b. Disponível em: <http://www.usp.br/revistausp/30/08-flora.pdf>. Acesso em: 15 mar. 2012. 
Tal Brasil, Qual Romance? Uma ideologia estética e sua história: o naturalismo. Rio de Janeiro: Achiamé, 1984.

TINHORÃO, José Ramos. Os Romances em Folhetins no Brasil: 1830 à atualidade. São Paulo: Duas Cidades, 1994.

TODOROV, Tzvetan. Introdução à Literatura Fantástica. Tradução de Maria Clara Correa Castello. 3. ed. São Paulo: Perspectiva, 2008.

VASCONCELOS, Sandra Guardini Teixeira. Caminhos do romance inglês no Brasil do século XIX. In: ABREU, Márcia; SCHAPOCHNIK, Nelson (Orgs.). Cultura Letrada no Brasil: objetos e práticas. Campinas: Mercado de Letras, 2005. p. 201-228.

Construções do feminino no romance inglês do século XVIII. Polifonia, Cuiabá, n. 2, p. 85-100, 1995.

2002a.

Dez Lições Sobre o Romance Inglês do Século XVIII. São Paulo: Boitempo,

Figurações do passado: o romance histórico em Walter Scott e José de Alencar. Terceira Margem: Revista da Pós-Graduação em Letras, Rio de Janeiro, n. 18, p. 15-37, jan./jun. 2008. Disponível em:

<http://www.letras.ufrj.br/ciencialit/terceiramargemonline/numero18/Terceira_Margem_18.p df>. Acesso em: 20 ago. 2012.

A formação do romance brasileiro: 1808-1860 (vertentes inglesas). In: CAMINHOS DO ROMANCE: Brasil - séculos XVIII e XIX. Campinas: Universidade Estadual de Campinas, 2002b, p. 1-43. Disponível em: 〈http://www.caminhosdoromance.iel.unicamp.br〉. Acesso em: 12 ago. 2011.

2007.

A Formação do Romance Inglês: ensaios teóricos. São Paulo: Hucitec; Fapesp,

VERÍSSIMO, José. Garrett e a literatura brasileira. In:

Estudos de Literatura

Brasileira. Belo Horizonte: Itatiaia; São Paulo: Ed. da Universidade de São Paulo, 1977. p. 95-103. 2. série.

O positivismo no Brasil. In:

Estudos de Literatura Brasileira. Belo

Horizonte: Itatiaia; São Paulo: Ed. da Universidade de São Paulo, 1976. p. 61-72. 1. série. 
VIEIRA, Nelson H. Brasil e Portugal - A Imagem Recíproca: o mito e a realidade na expressão literária. Lisboa: Ministério da Educação; Instituto de Cultura e Língua Portuguesa, 1991.

VOLOBUEF, Karin. Frestas e Arestas: a prosa de ficção do romantismo na Alemanha e no Brasil. São Paulo: Fundação Editora da UNESP, 1999.

WATT, Ian. A Ascensão do Romance. Tradução de Hildegard Feist. 2. ed. São Paulo: Companhia das Letras, 2007.

WOLF, Ferdinand. O Brasil Literário: história da literatura brasileira. Tradução de Jamil Almansur Haddad. São Paulo: Companhia Editora Nacional, 1955.

ZILBERMAN, Regina; MOREIRA, Maria Eunice. O Berço do Cânone: textos fundadores da história da literatura brasileira. Porto Alegre: Mercado Aberto, 1998.

ZOLA, Emile. O romance experimental. In: O Romance Experimental e o Naturalismo no Teatro. Tradução de Ítalo Caroni; Célia Berrettini. São Paulo: Perspectiva, 1979. p. 25-76.

O senso do real. In: Do Romance. Tradução de Plínio Augusto Coelho. São Paulo: Edusp, 1995. p. 23-48. 


\subsubsection{Periódicos, catálogos e sites consultados}

ARTE LIVRE: Revista Semanal de Arte e Literatura. Braga, 1897.

BIBLIOGRAFIA PORTUGUESA E ESTRANGEIRA. Porto; Braga: Livraria Internacional de Ernesto Chardron, 1879-1883.

GAZETA ILLUSTRADA: O Atheneu Artistico-Litterario - Publicação de Ensino, Educação e Recreio, e das Conquistas da Civilização Moderna. Porto, 1881.

GAZETA LITTERARIA DO PORTO: Periódico Semanal. Porto: Tipografia da Livraria de A. de Moraes \& Pinto, 1868.

LIVRARIA CULTURA. Disponível em: 〈http://www.livrariacultura.com.br〉. Acesso em: 22 jan. 2013.

REVISTA CONTEMPORÂNEA DE PORTUGAL E BRAZIL. Lisboa: Tipografia FrancoPortugueza, 1859-1864.

REVISTA DE ESTUDOS LIVRES. Lisboa: Nova Livraria Internacional Editora, 1883-1884. 
9.4 Títulos diversos de crítica, história, teoria e comparativismo literário

ABDALA JUNIOR, Benjamin. De Voos e Ilhas: literatura e comunitarismos. São Paulo: Ateliê, 2003.

ABREU, Maria Fernanda de. Paródia. In: BUESCU, Helena Carvalhão (Coord.). Dicionário do Romantismo Literário Português. Lisboa: Caminho, 1997. p. 405-408.

CALVINO, Ítalo. Por que ler os clássicos. In: Por que Ler os Clássicos. Tradução de Nilson Moulin. São Paulo: Companhia das Letras, 1993. p. 9-16.

CANDIDO, Antonio. Literatura e subdesenvolvimento. In:

Outros Ensaios. São Paulo: Ática, 1987. p. 140-162.

A Educação pela Noite e

CARVALHAL, Tânia Franco. Literatura Comparada. 4. ed. São Paulo: Ática, 2006.

BAKHTIN, Mikhail. Problemas na Poética de Dostoiévski. 2. ed. Tradução de Paulo Bezerra. Rio de Janeiro: Forense Universitária, 1997.

Questões de Literatura e de Estética: a teoria do romance. Tradução de Aurora Fornoni Bernardini et al. 5. ed. São Paulo: Annablume; Hucitec, 2002.

CARVALHO, José Murilo de. Teatro de Sombras: a política imperial. São Paulo: Vértice, Editora Revista dos Tribunais; Rio de Janeiro: Instituto Universitário de Pesquisas do Rio de Janeiro, 1988.

CEVASCO, Maria Elisa. Dez Lições Sobre Estudos Culturais. São Paulo: Boitempo, 2003.

DICIONÁRIO HOUAISS DA LÍNGUA PORTUGUESA. Rio de Janeiro: Objetiva, 2001.

DUARTE, Lélia Parreira. Ironia e Humor na Literatura. Belo Horizonte: PUCMinas; Alameda, 2006.

ECO, Umberto. Cultura de massa e "níveis" de cultura. In: Apocalípticos e Integrados. São Paulo: Perspectiva, 1970. p. 33-67. 
ESCOSTEGUY, Ana Carolina D. Estudos culturais: uma perspectiva histórica. In:

Cartografias dos Estudos Culturais: uma versão latino-americana. Belo Horizonte: Autêntica, 2001. p. 21-58.

FERRAZ, Maria de Lourdes A. A Ironia Romântica: estudo de um processo comunicativo. Lisboa: Imprensa Nacional; Casa da Moeda, 1985.

GENETTE, Gérard. Palimpsestes: la littérature au second degré. Saint-Amand: Éditions Du Seuil, 1982.

HANSEN, João Adolfo. Alegoria: estado da questão. In: . Alegoria: construção e interpretação da metáfora. São Paulo: Hedra; Campinas: Editora da Unicamp, 2006. p. 7-26.

HOBSBAWM, Eric J. A Era das Revoluções: 1789-1848. Tradução de Maria Tereza Lopes Teixeira; Marcos Penchel. 21. ed. São Paulo: Paz e Terra, 2007a.

A Era do Capital: 1848-1875. Tradução de Luciano Costa Neto. 12. ed. São Paulo: Paz e Terra, 2007b.

A Era dos Impérios: 1875-1914. Tradução de Sieni Maria Campos; Yolanda Steidel de Toledo. 11. ed. São Paulo: Paz e Terra, 2007c.

HUTCHEON, Linda. Uma Teoria da Paródia. Tradução de Teresa Louro Pérez. Lisboa: Edições 70, 1985.

JOBIM, José Luiz. História da Literatura. In: JOBIM, José Luiz (Org.). Palavras da Crítica: tendências e conceitos no estudo da literatura. Rio de Janeiro: Imago, 1992. p. 127-149.

KRISTEVA, Julia. Introdução à Semanálise. Tradução de Lúcia Helena França Ferraz. São Paulo: Perspectiva, 1974.

LOURENÇO, Eduardo. O Labirinto da Saudade: psicanálise mítica do destino português. 6 . ed. Lisboa: Gradiva, 2009.

A Nau de Ícaro e Imagem e Miragem da Lusofonia. São Paulo: Companhia das Letras, 2001. 
LUKÁCS, Georg. O romance como epopeia burguesa. Tradução de Letizia Zini Antunes. Ad Hominem: Revista de Filosofia, Política, Ciência da História, Santo André, n. 1, p. 87-117, 1999.

A Teoria do Romance: um ensaio histórico-filosófico sobre as formas da grande épica. Tradução de José Marcos Mariani de Macedo. São Paulo: Duas Cidades; Editora 34, 2000.

MARQUES, A. H. de Oliveira. História de Portugal: desde os tempos mais antigos até a presidência do Sr. General Eanes. Lisboa: Palas Editores, 1980.

MARTINS, José Cândido. Teoria literária da paródia. In: Teoria da Paródia Surrealista. Braga: APPACDM, 1995. p. 29-69.

MOISÉS, Massaud. Dicionário de Termos Literários. 12. ed. São Paulo: Cultrix, 2004.

PROPP, Vladímir. Comicidade e Riso. Tradução de Aurora Fornoni Bernardini; Homero Freitas de Andrade. São Paulo: Ática, 1992.

RAMA, Ángel. Literatura e Cultura na América Latina. Tradução de Raquel la Corte dos Santos; Elza Gasparotto. São Paulo: Editora da Universidade de São Paulo, 2001.

REGO, Enylton José de Sá. O Calundu e a Panaceia: Machado de Assis, a sátira menipeia e a tradição luciânica. Rio de Janeiro: Forense Universitária, 1989.

REIS, Carlos; LOPES, Ana Cristina M. Dicionário de Narratologia. 4. ed. Coimbra: Livraria Almedina, 1994.

REIS, Roberto. Cânon. In: JOBIM, José Luís (Org.). Palavras da Crítica: tendências e conceitos no estudo da literatura. Rio de Janeiro: Imago, 1992.

ROSENFELD, Anatol. O Teatro Épico. 4. ed. São Paulo: Perspectiva, 2006.

SANTIAGO, Silviano. Eça, autor de Madame Bovary. In: Uma Literatura nos Trópicos. São Paulo: Perspectiva, 1978. p. 49-65. 
SANTOS, Boaventura de Sousa. Pela Mão de Alice: o social e o político na pósmodernidade. 7. ed. Porto: Edições Afrontamento, 1994.

SCHLEGEL, Friedrich. Conversa Sobre a Poesia e Outros Fragmentos. Tradução de Victor-Pierre Stirnimann. São Paulo: Iluminuras, 1994.

SCHWARZ, Roberto. Adequação nacional e originalidade crítica. In: Sequências Brasileiras: ensaios. São Paulo: Companhia das Letras, 1999. p. 24-45.

Nacional por subtração. In: Que Horas São? Ensaios. São Paulo: Companhia das Letras, 1987.

SILVA, Vítor Manuel de Aguiar e. Antelóquio sobre o esplendor e o declínio da história literária. In: CUNHA, Carlos Manuel Ferreira da. A Construção do Discurso da História Literária na Literatura Portuguesa do Século XIX. Braga: Universidade do Minho; Centro de Estudos Humanísticos, 2002. p. 1-7.

Teoria da Literatura. 2. ed. São Paulo: Martins Fontes, 1968.

TODOROV, Tzvetan. The origin of genres. Translated by Richard M. Berrong. New Literary History, v. 8, n. 1, p. 159-170, Aut. 1976. Disponível em:

<http://pt.scribd.com/doc/73189601/Todorov-Origin-of-Genres>. Acesso em: 15 jun. 2012. 